UNIVERSIDADE DE SÃO PAULO

FACULDADE DE FILOSOFIA, LETRAS E CIÊNCIAS HUMANAS

DEPARTAMENTO DE GEOGRAFIA

\title{
MOBILIZAÇÃO E MODERNIZAÇÃO NOS CERRADOS PIAUIENSES: FORMAÇÃO TERRITORIAL NO IMPÉRIO DO AGRONEGÓCIO
}

\author{
Vicente Eudes Lemos Alves \\ Orientador: Prof. Dr. Heinz Dieter Heidemann
}

Tese apresentada ao Programa de PósGraduação em Geografia Humana, do Departamento de Geografia, Faculdade de Filosofia, Letras e Ciências Humanas, Universidade de São Paulo, para obtenção do título de Doutor. 
Aos meus pais, seu Raimundo e dona Raimunda, pelos ensinamentos de vida, pelo carinho e pelos enormes esforços pessoais dispensados para que eu pudesse estudar. 


\section{AGRADECIMENTOS}

À Mónica, pelo seu amor, companheirismo e pelo apoio sempre presentes ao longo da nossa caminhada;

À Ofélia, ao Vinícius e ao Rafael, pelo amor, carinho e compreensão demonstrados em todos os momentos. Peço-lhes desculpas pelas minhas ausências;

Aos meus irmãos (Corina, Wildes, Edson, Daniel) e às minhas cunhadas Tatiana e Carol, pelos momentos que a vida nos proporciona de estarmos juntos, pela nossa união e pelos incentivos mútuos;

Aos meus familiares, em especial, a Milvanês, Zildene, Natal, Teodoro, Lucas, Gessiário, Darinha, Roberto, Bruno e Kelvin, pela convivência em São Paulo;

Aos meus queridos amigos, Rinaldo, Ana e Giovana (minha afilhada), pela presença constante na minha vida e pelas alegrias da nossa convivência. Essas palavras são extensivas a todos os Pinho, "autênticos" e agregados, família que aprendi a admirar. Sou extremamente grato ao Rinaldo pela elaboração dos mapas, sem a sua ajuda não teria condições de avançar nessa etapa do trabalho;

Aos amigos Flávia e Alexandre, pelas trajetórias alegres de vida na geografia e em Carapicuíba. Agradeço à Flávia, pelo auxílio competente e generoso na organização final do texto;

Aos meus queridos amigos e vizinhos, Pablo e Magdalena, pela ajuda e pelo compartilhamento das minhas angústias e alegrias;

Aos meus amigos Nelson e Jaqueline, pela convivência e incentivos;

A Aníbal, Marcela e Isabel, por compartilhar momentos de alegria. Sou grato ao Aníbal, pelo importante apoio na tradução do resumo para a língua inglesa;

A todos os meus amigos da comunidade latina, pelos nossos momentos alegres "bailando salsa";

Ao meu amigo Edu, que, além do incentivo, prestou-me uma valiosa ajuda enviando, diretamente do Rio Grande do Sul, material de pesquisa sobre os sulistas; 
Às minhas amigas queridas Maria Laura, Perla e Aida, pelo apoio sempre fraterno e delicado, e por me fazerem acreditar, com suas firmezas teóricas, que é possível construir uma sociedade mais solidária;

À Marie-Hélène, pelo carinho e sensibilidade frente aos movimentos sociais brasileiros;

Aos meus familiares e amigos, pela acolhida fraterna no Piauí durante as visitas de campo:

- Em Redenção do Gurguéia:

À tia Nezita, que gentilmente me hospedou em sua casa por várias vezes;

À Calú, Joveci, Robeíres, Joseildo, Izinha, Demerson e as crianças; Bilí, Salvador e as meninas, Irismar, Raimundo, Talminho e Ricardinho; tia Darci, tio Abílio (em memória) e meus primos e primas;

À tia Melânia, tia Darci e meus primos e primas. Um agradecimento especial a Cristóvão (em memória), que partiu, mas deixou em Redenção a sua alegria e os ensinamentos a distintas gerações de alunos seus;

A toda a família de tio Elisiário e tia Claudina, pelas conversas alegres nas tardes ensolaradas frente a sua casa;

- Em Monte Alegre:

A tio Marcos, pela acolhida em sua casa desde a minha infância, momentos de grandes alegrias compartidas com os meus primos e a minha tia Didi (em memória);

A João, Jussara e os meninos, que carinhosamente me hospedaram em sua casa;

A Milvan, Naidir, e Naiane, pelo apoio tão gentilmente prestado quando precisei;

A Milvaldo, Neide, Paulinho, Danila e Marquinho, pelos inestimáveis auxílios em todas as viagens e por me proporcionarem momentos de alegria em suas companhias;

Agradeço especialmente a meu primo Milonês (em memória) que nos deixou antes do término dessa pesquisa, partilhei momentos felizes em sua presença em Monte Alegre; partiu, mas deixou saudades; 
- Em Bom Jesus:

À dona Bia, que me auxiliou quando permaneci por três meses no município;

- Em Teresina:

À Luiza Maria, pelo carinhoso acolhimento em sua casa;

À minha amiga Márcia Regia Soares de Araújo, pelos diálogos frutíferos que mantivemos, via e-mails, sobre nossas áreas em comum de pesquisa, os cerrados piauienses;

Retornando a São Paulo, sou grato aos meus alunos e colegas da Universidade Guarulhos (UnG), dos cursos de Geografia e de Turismo, pelos incentivos;

Aos meus amigos do cursinho Prestes, em Carapicuíba, com os quais partilho sonhos de uma sociedade mais justa;

Ao Zé, pelas discussões sobre os brejos baianos e piauienses, universos que aproximam nossas pesquisas;

Aos meus amigos desde a graduação: Raildo, Soraia, André, Osvaldo, Laila, Nilo, Adriana, Gê, Fábio, Eliza, Scarin, Paula e Doraci, pelos encontros sempre muito descontraídos;

Às funcionárias da Secretária de Pós-graduação: Ana, Jurema, Maria Aparecida e Rosângela, pelo cordial e eficiente atendimento dispensado às minhas demandas;

Ao $\mathrm{CNPq}$, por me conceder uma bolsa de estudo durante 48 meses, auxílio financeiro fundamental para levar adiante a pesquisa;

Aos professores Ariovaldo Umbelino de Oliveira e Odette Seabra, pelas críticas e novos caminhos apontados no Exame de Qualificação;

A minha orientadora do mestrado, Iraci Gomes de Vasconcelos Palheta, pela amizade e confiança depositadas em mim, e pela forma carinhosa com que me acolheu desde a graduação;

Aos meus amigos e companheiros de discussão no Grupo Crisis/Exit: Carlão, Caio, Carol, Conceição, Cássio, Bete e Érik; agradeço a todos pela leitura crítica do trabalho; especialmente ao Carlão e ao Cássio, pela leitura mais detida e cuidadosa na fase de finalização, com suas sugestões e críticas para melhorar o texto. Ao Cássio, agradeço ainda pela competente revisão gramatical; peço desculpas a todos se não correspondi ao esperado; 
Finalmente, agradeço ao meu orientador, Professor Doutor Heinz Dieter Heidemann, pela amizade, pela presença constante nas discussões dos diferentes grupos de estudo que participei no Departamento de Geografia e no Instituto de Estudos Brasileiros, e pela sua sabedoria na maneira de orientar, oferecendo-nos liberdade para escolher caminhos, mas sem, entretanto, se eximir do papel de cobrar coerência nos nossos posicionamentos metodológicos. 


\section{SUMÁRIO}

ÍNDICE DE ILUSTRAÇÕES $\quad X$

RESUMO XIV

$\begin{array}{lll}\text { ABSTRACT } & \mathrm{XV}\end{array}$

INTRODUÇÃO

\section{1 - A SOJA E A FORMAÇÃO DA FRONTEIRA AGRÍCOLA NOS} CERRADOS BRASILEIROS

1.1 - A expansão da produção de soja no Brasil e a manutenção do sentido agrário exportador

1.2 - As novas formas de financiamento agrícola nas décadas de 1980 e 1990

1.3 - A participação das empresas processadoras de soja no sistema de crédito agrícola

1.4 - As empresas processadoras e a concentração de capital no circuito da soja

1.5 - As formas de crise da soja

32

1.6 - A disputa capitalista pelas terras dos cerrados, antes e depois da expansão da soja

1.7 - A formação da logística de transporte nas áreas de expansão da agricultura moderna

2 - A REPRODUÇÃO DO CAPITAL NOS CERRADOS NORDESTINOS

2.1 - Cerrados nordestinos: configuração de uma região do agronegócio

2.2 - Uma breve incursão pela região

2.3 - Os cerrados baianos e suas novas dinâmicas: os casos de Barreiras e Luis Eduardo Magalhães

2.3.1 - Barreiras: ascensão e perda da centralidade do agronegócio nos cerrados nordestinos

2.3.2 - Luis Eduardo Magalhães (LEM) e a busca da homogeneização nos cerrados baianos através do fetiche da mercadoria 


\section{3 - A CORRENTE MIGRATÓRIA SULISTA E A OCUPAÇÃO DOS}

CERRADOS PIAUIENSES

3.1 - A mobilização do trabalho no Brasil: algumas considerações

3.2 - A corrente sulista: do núcleo irradiador à sua expansão pelo território brasileiro

122

3.3 - As transferências de agricultores do Sul do Brasil para a nova fronteira agrícola

3.4 - A presença dos sulistas nos cerrados piauienses

132

3.4.1 - A corrente sulista e o encontro de suas ramificações nos cerrados piauienses

3.5 - O trabalho como elemento diferenciador entre o sulista e o piauiense

150

3.6 - As características sócio-econômicas do migrante sulista nos cerrados piauienses

4 - OS CERRAdOS PIAUIENSES E A SUA NOVA LÓGICA DE REPRODUÇÃO CAPITALISTA

4.1 - As características da expansão da agricultura capitalista nos cerrados piauienses

4.2 - Os cerrados piauienses e as iniciativas governamentais direcionadas à aceleração dos processos de modernização

4.3 - A ocupação recente dos gerais sul-piauiense: a apropriação irregular da terra comunitária

4.4 - O avanço da grilagem nos gerais piauienses

188

4.5 - A expansão do trabalho precarizado nas fazendas de soja dos cerrados piauienses

198

\section{5 - AS TRANSFORMAÇÕES NO URBANO DOS CERRADOS} PIAUIENSES

5.1 - O antigo urbano dos cerrados piauienses e suas novas dinâmicas

5.2 - A ocupação dos gerais piauienses para a formação de núcleos urbanos: o caso de Nova Santa Rosa 
6 - A PRESENÇA dA bUnge ALImENTOS E DE OUTRAS EMPRESAS DO AGRONEGÓCIO NO SUL DO PIAUÍ

6.1- A instalação da Bunge Alimentos no Piauí

6.2 - A presença da Bunge Alimentos e de outras empresas nos cerrados piauienses e a questão ambiental 


\section{ÍNDICE DE ILUSTRAÇÕES}

\section{Gráficos}

Gráfico $01 \quad$ Evolução das principais culturas agrícolas - Brasil 16

Gráfico $02 \quad$ Exportações do complexo soja - Brasil 36

Gráfico 03 Cotações médias do complexo soja na Bolsa de Chicago 37

Gráfico 04 Evolução da área ocupada com soja em anos selecionados Brasil e Grandes Regiões (em mil hectares)

Gráfico $05 \quad$ Número de estabelecimentos com pessoal ocupado em todas as atividades econômicas no município de Barreiras - BA

Gráfico $06 \quad$ Número de estabelecimentos com pessoal ocupado em todas as atividades econômicas no município de Luis Eduardo Magalhães - BA

Gráfico 07 Pessoal ocupado total em todos os estabelecimentos e atividades econômicas no município de Balsas - MA

Gráfico 08 Presença de sulistas nos municípios de Bom Jesus e Uruçuí segundo a unidade da federação de nascimento na região Sul - ano 2000

Gráfico 09 Evolução da produção de soja e arroz no estado do Piauí

Gráfico 10 Evolução da produção de arroz e soja nos municípios de Bom Jesus e Uruçuí (em toneladas)

Gráfico 11 Admissões e desligamentos de trabalhadores em municípios selecionados dos cerrados piauienses entre janeiro de 2000 e dezembro de 2005

Gráfico 12 Evolução do número de estabelecimentos em todas as atividades econômicas em municípios selecionados dos cerrados piauienses

\section{Mapas}

Mapa 01 Principais Países Importadores de Soja em Grãos do Brasil 2005

Mapa 02 Produção de Soja no Brasil, por Município - 2005

Mapa 03 Localização do Bioma Cerrado no Brasil

Mapa 04 Transporte de Soja da Região Norte de Mato Grosso - Ano 2000

Mapa 05 Transporte de Soja da Região Centro Leste do Mato Grosso Ano 2000 
Mapa 06 Transporte de Soja da Região Sul do Maranhão e Piauí - Ano 2000

Mapa 07 Transporte de Soja da Região Oeste da Bahia - Ano 2000

Mapa 08 Localização dos Cerrados Nordestinos

Mapa 09 Produção de Soja nos Cerrados Nordestinos, por Município 2005

Mapa 10 Migração dos Colonos Gaúchos na Região Sul do Brasil

120

Mapa 11 Presença de Migrantes Sulistas no Brasil e em Países da América do Sul - 1950 a 2000

Mapa 12 População Sulista nos Estados dos Cerrados Nordestinos

135

Mapa 13 Evolução da Mancha Urbana do Município de Bom Jesus (PI) 1995 a 2002

Mapa 14 Presença da Bunge Alimentos nos Cerrados Nordestinos: Fábricas, Silos e sua Área de Influência

Figuras

Figura 01 Croqui do Loteamento Portal dos Cerrados

Figura 02 Evolução do uso do solo no Município de Bom Jesus - Piauí (anos 1990, 2000 e 2004)

Figura 03 Evolução do uso do solo no Município de Uruçuí - Piauí (anos 1990, 2000 e 2004)

\section{Fotos}

Foto 01 Relevo e vegetação característicos dos platôs planos dos cerrados nordestinos

Foto 02 Posto Mimoso - ao redor do qual iniciou-se o povoado de Mimoso do Oeste, atual cidade de Luis Eduardo Magalhães

Foto 03 Loteamento em formação no município de Luis Eduardo Magalhães

Foto 04 Rua do bairro de Santa Cruz em Luis Eduardo Magalhães área de grande concentração de migrantes nordestinos

Foto $05 \quad$ Bairro de Santa Cruz - área com grandes carências de infraestrutura urbana

Foto $06 \quad$ Entrada de um dos condomínios em Luis Eduardo Magalhães

Foto 07 Entrada de condomínio ainda em formação no município de Luis Eduardo Magalhães 
Foto 08 Centro de Tradições Gaúchas (CTG) em Luis Eduardo Magalhães

Foto 09 Vista panorâmica de um dos novos bairros de Balsas

Foto 10 Casa do condomínio Jardim do Sol em Balsas

113

Foto $11 \quad$ Bairro de São Félix na periferia de Balsas

114

Foto 12 Área sendo preparada para o plantio de soja nos gerais de Balsas

Foto 13 Grupo de migrantes sulistas compradores de terra no sul do Piauí

Foto 14 Jovem família gaúcha instalada em Nova Santa Rosa

Foto 15 Residências instaladas em Nova Santa Rosa - a arquitetura das casas demonstra a influência cultural dos migrantes sulistas na atual organização do espaço dos gerais piauienses

Foto 16 Apresentação de dança folclórica sulista na "Primeira Festa Gaúcha de Bom Jesus"

Foto 17 Senhoras gaúchas moradoras da agrovila Nova Santa Rosa

Foto 18 Agrovila Manoel Dias Branco habitada por antigos posseiros da área adquirida pela empresa Anna Purna

186

Foto 19 Cemitério instalado próximo a agrovila Manoel Dias Branco com os restos mortais retirados da área adquirida pela empresa Anna Purna

Foto 20 Pizzaria no município de Bom Jesus

Foto 21 Novos serviços instalados nas cidades dos cerrados piauienses, até recentemente estranhos à população local Bom Jesus

Foto 22 Bairro pobre de Uruçuí expandido nos últimos anos por conta da migração de antigos posseiros para o urbano

Foto 23 Vista panorâmica da agrovila Nova Santa Rosa.

Foto $24 \quad$ Núcleo urbano de Nova Santa Rosa. Os traçados das ruas indicam uma futura urbanização seguindo o padrão das novas cidades da fronteira agrícola brasileira

Foto $25 \quad$ Loteamento Portal dos Cerrados

Foto 26 Loteamento Portal dos Cerrados em formação, habitado por representantes do agronegócio, localiza-se cerca de 25 quilômetros da sede do município de Uruçuí

Foto 27 Posto Cacique - no seu entorno ocorre grande movimento de 
caminhões por conta da presença da Bunge Alimentos instalada nas proximidades

Foto 28 Alunos da única escola instalada na agrovila Nova Santa Rosa. Observa-se a presença de piauienses e filhos de colonos sulistas

Foto 29 Reunião de mulheres moradoras em Nova Santa Rosa. Os encontros femininos são freqüentes e visam amenizar a solidão de um espaço em construção

Foto $30 \quad$ Planta de fábrica da Bunge Alimentos em Uruçuí

Foto 31 Silos construídos pela Cotrirosa em Nova Santa Rosa, vendidos posteriormente para Bunge Alimentos

Foto 32 Campos de soja no município de Uruçuí - o espaço de produção ganha cada vez mais homogeneidade

Foto 33 Rio Gurguéia - o problema do assoreamento se agravou nos últimos anos com a ocupação dos gerais

Fotos 34 Desmatamento até o limite das bordas dos tabuleiros, prática que intensifica os processos erosivos e os riscos de desaparecimento dos nascedouros dos cursos d'água em gerais de Balsas

Foto $35 \quad$ Ocupação das bordas dos tabuleiros

\section{Tabelas}

Tabela 01 Região oeste da Bahia - safra de grãos 2004/2005

Tabela 02 População total residente no município de Barreiras - BA por situação de domicilio

Tabela 03 Produção de algodão e feijão no município de Barreiras - BA

Tabela 04 Veículos cadastrados no município de Barreiras - BA, segundo o tipo $(1995-2003)$

Tabela 05 Arrecadação de ICMS nos municípios de Barreiras e Luis Eduardo Magalhães (1995 - 2003) - em reais

Tabela 06 Série histórica das safras de soja - Estado do Maranhão

Tabela 07 Conflitos de terra no estado do Maranhão e na mesorregião sul maranhense $1997-2003$

Tabela 08 Área total do município e área total de terras devolutas de municípios selecionados nos cerrados piauienses (em hectares) 


\section{RESUMO}

Objetiva-se, nesse estudo, analisar os novos processos de modernização que se impõem nos cerrados piauienses produzidos pela presença da agricultura moderna. Tal movimento teve inicio nos anos 1970 com os primeiros projetos agropecuários e de reflorestamentos instalados através de incentivos fiscais e financeiros públicos, mais se consolida somente em meados dos anos 1990 com a ampliação do deslocamento de migrantes sulistas e de empresas do agronegócio para aquela área. Resultou dessa ocupação a apropriação privada de amplas parcelas de terras devolutas dos platôs planos onde havia uso comunitário pela população local, as quais são transformadas em mercadorias valorizadas no mercado imobiliário. As manifestações de mudanças aparecem tanto sobre o espaço agrícola que se altera diante da incorporação dos aparatos da técnica e da ciência tornando-se homogêneos, e sobre o espaço da cidade que ganha novas formas e funcionalidades. Tanto o rural quanto o urbano do sul do Estado do Piauí revelam os processos contraditórios da recente modernização, pois se transformam, simultaneamente, em espaços de produção de riqueza e de manifestação de crises. Ao mesmo tempo em que se anunciam formas inovadoras que aceleram o ritmo de produção e de circulação das mercadorias sob a liderança de empresas globais, evidencia-se a expropriação de levas de camponeses cujas únicas possibilidades disponíveis passam a ser a de venderem sua força de trabalho nas lavouras modernas de grãos em condições de extrema precarização, ou a de se instalarem nas periferias miseráveis das cidades do agronegócio. Acrescenta-se, ainda, como elemento da crise o agravamento das condições de degradação dos ambientes naturais por conta do avanço acelerado das lavouras modernas nos domínios dos gerais, afetando os ecossistemas locais. Busca-se, nesse sentido, apontar que a atual modernização dos cerrados piauienses se faz produzindo descompassos sócio-espaciais. Ela se configura, portanto, como um processo essencialmente excludente.

Palavras-chave: mobilização, modernização, agronegócio, crise, fronteira agrícola, cerrados piauienses 


\section{ABSTRACT}

This study analyzes the new modernization processes raised at the cerrados in Piauí due to modern agriculture. This movement started in the early 1970 's together with the first cattle breeding and reforesting projects developed through state financial and fiscal incentives. These projects only started to consolidate around 1990's as the displacement of people and agricultural business firms from the south of Brazil ("sulistas") to Piauí increased. The result of this land occupation was the appropriation of vast plain plateaus escheated lands of communitarian use that turned to be commodities. These lands were valorized by housing market. Signs of these changes appeared both on the agricultural space, transformed by means of applying scientific and technological objects, which turned the space homogeneous, and the city space, that gained new shape and functionalities. Piaui's southern urban and rural areas reveal contradictory process of this recent modernization, transformed simultaneously into spaces where richness and crisis manifestations are both produced. While innovation accelerating the production rhythm and the circulation of goods under global companies' leadership is announced, the expropriation of peasants groups stands out. Now their possibilities only depend on selling their task force in the new corporate farming business in extremely hard working conditions or installing themselves at the poor outskirts of this agricultural business related cities. Furthermore, natural environment's worsening conditions are a result of modern agricultural technology at those gerais. These conditions affect local ecosystems and add up another element to the crisis. In this way we intend to point out that the modernization of the cerrados piauienses is generating a socio-spatial imbalance, which configures itself as an essentially excluding process.

Key words: mobilization, modernization, agribusiness, crisis, agrarian frontier, cerrados piauienses. 


\section{INTRODUÇÃO}

Pensar a sociedade brasileira de hoje exige buscar elementos no seu passado que apontem os caminhos percorridos pelo país ao longo de sua formação. O Brasil (assim como os demais países que viveram um processo de colonização) surge, na lógica de expansão capitalista, como produtor de mercadorias para o centro do sistema. Nesse sentido, mesmo sendo incorporado em plena vigência do sistema capitalista, o país já emerge moderno, na medida em que, desde os seus primeiros passos, a mediação que se estabelece é a da forma mercadoria. A construção da identidade brasileira, portanto, fez-se pela via da modernização e (como tal) é marcada por crises em toda a sua formação sócio-espacial. O país, que assim se constitui, possui nas suas estruturas as marcas de uma organização espacial cujo objetivo é o de produção de mercadorias para a exportação. Tanto as formas de organização do Brasil colônia, quanto as que apareceram quando já havia se transformado em Estado nacional, foram ajustadas pelos desígnios de outros, naquilo que Caio Prado Jr. (1965) define como sendo o sentido da formação desse território, qual seja, o de nos voltarmos para a produção de coisas destinadas ao mercado externo. Nos dois momentos, entretanto, o Brasil se configura como território do capital, a diferença é que na primeira situação é mais o poder político e coercitivo da metrópole que determina o que se deve produzir nesse território; na segunda é mais a determinação econômica demandada pelo mercado do centro que se transforma nas forças motrizes da organização de um sistema nacional de produção de mercadorias. Com o Estado nacional autônomo é que se intensifica a busca por uma formação de uma estrutura econômico-social capaz de sustentar os organismos necessários

para garantir o abastecimento das demandas do centro do sistema. É com o apoio desse Estado nacional que o capital vai se valer para colocar em circulação as mercadorias tropicais destinadas à Europa; para tanto, apropriase das distintas formas de violência disponibilizadas pelo Estado visando enquadrar os lugares e neles os grupos sociais para se tornarem produtores dos bens necessários para a assim chamada acumulação primitiva (Marx, 1968 [1890]) das metrópoles. 
A adequação do território à lógica da produção de mercadoria resultou em um espaço nacional sob o controle do capitalismo mundial, o que impôs um movimento sempre reposto de modernização para a superação (quase nunca conseguida) de não simultaneidade externa e interna (Kurz, 2002). Ou seja, ao mesmo tempo em que a expansão do capitalismo gerava acumulação de riquezas e a formação do trabalho livre no centro (na Europa), na periferia do sistema (no Brasil e nos demais países colonizados) produzia a miséria e o trabalho escravo. Apesar de constituírem-se movimentos opostos, são partes de uma mesma freqüência dos processos de organização econômica. Tal descompasso também ocorre internamente no centro e na periferia. A eleição de espaços do território nacional, em cada momento histórico, para responder à valorização do valor possibilitou a ocorrência de trocas de mercadorias e relações de trabalho desiguais dentro dos próprios países.

O fato da tomada de decisões pertencer ao centro, deliberou em cada uma dessas situações a determinação do tipo de mercadoria que se deveria produzir, obrigando aos territórios em formação freqüentes adaptações de suas estruturas aos desígnios do capital. Das ingerências do grande mercado consumidor resultam as dinâmicas dos lugares, ora se colocando em evidência por produzir as mercadorias demandadas pelo mercado, ora se "submergindo" quando as mercadorias que produzem tornam-se menos rentáveis ao circuito do capital. Provêm dessa lógica as diferentes tentativas de aceleração de modernização pelas quais o Brasil passou.

Os processos que estabeleceram não-simultaneidades estiveram presentes também com a constituição social brasileira que, desde os primeiros passos de sua formação nacional, pautou-se por enormes desigualdades. A sedimentação desses alicerces mostra que a modernização se apoiou no uso de diferentes mecanismos de coerção contra os mais variados grupos sociais locais. Para tanto, o sistema produtor de mercadoria se apropriou de uma massa de desvalidos que ele mesmo criou para a exploração de sua força de trabalho, impondo a eles formas precárias de vida. A sociedade brasileira se organiza, desse modo, deparando-se a todo instante com formas nãohomogêneas para a sua reprodução. A cada nova tentativa de aceleração da modernização que busca homogeneizar os processos através de relações capitalistas mantidas pelo assalariamento e pelo tempo dinâmico e abstrato, o 
sistema convive e se alimenta das formas de exploração do trabalho similares às do período escravista e de uma estrutura fundiária concentrada. A persistência dessas velocidades distintas de modernização é o que caracteriza a não -simultaneidade do processo de formação brasileira.

Lembramos que o conceito de não-simultaneidade adotado nessa pesquisa possui como foco o papel supremo que exerce a mercadoria no funcionamento do sistema produtor de mercadorias, revelando formas nãohomogêneas ou em permanente descontinuidade. $O$ fato de se colocar a mercadoria como sendo o núcleo da análise não quer dizer que se optou pelo abandono por completo da dinâmica dialética das classes, mas consiste em afirmar que a mediação social se faz é pela forma mercadoria. Esse fato possibilita que apenas alguns consigam vencer momentaneamente no jogo desigual do mercado, enquanto parcelas cada vez maiores da população tornam-se perdedoras, excluídas de participar como consumidores, principalmente pela impossibilidade de obter dinheiro vendendo a sua força de trabalho, também ela uma mercadoria (a única que possuem).

Se a forma mercadoria está no núcleo da organização do sistema, sendo ela a principal responsável pela impulsão do movimento de expansão capitalista, a mobilização do trabalho, do mesmo modo, é parte constitutiva dessa sociedade. É através do trabalho transformado em mercadoria que se forjam as condições para a existência do valor e, por conseguinte, as garantias para a reprodução do capital. Mobilizar trabalho, portanto, é disponibilizar as engrenagens para a expansão do processo produtivo (Gaudemar, 1977).

Para entender a construção das bases do território brasileiro é necessário, portanto, recorrer também ao processo de mobilização do trabalho, pois foi a constituição de um mercado de força de trabalho em disponibilidade que garantiu a acumulação capitalista e, por conseqüência, a herança que temos hoje nas características de nossa formação sócio-espacial. Da mesma maneira em que as relações mediadas por mercadorias particulares entram em cena definindo uma nova configuração da paisagem, grupos de trabalhadores também são selecionados para tornarem-se parte do processo global de realização do capital. O caso brasileiro é ilustrativo dessas estratégias do capital; quando foi necessário, colocou em movimento a força de trabalho do imigrante europeu, em outro momento foi a do migrante nacional, a escolha de 
um ou de outro dependia das conveniências que se colocavam em cada período histórico.

A mobilização do trabalho cumpre, assim, um papel-chave nas discussões desta pesquisa. Um dos focos é a questão da migração de agricultores sulistas deslocados para os cerrados nordestinos, particularmente, os piauienses. Esse grupo é responsável atualmente por impulsionar a agricultura modernizada na região. A chegada da soja no Piauí também representa um fator importante, na medida em que tal mercadoria ganhou centralidade nos últimos anos e se constitui atualmente no principal produto de transformação da paisagem daquele estado. O novo uso capitalista que ocorre do território sul-piauiense, sustentado na agricultura moderna, é um fenômeno que se espalha nas últimas décadas por amplas áreas do centro-norte do Brasil onde se consolida a denominada "fronteira agrícola", designação que adotaremos nesse trabalho para indicar os espaços de produção agrícola moderna.

Cabe, aqui, todavia, um breve esclarecimento do que estamos considerando, na pesquisa, por fronteira agrícola. Referimos-nos a ela, apoiando-nos no conceito desenvolvido por Martins (1997), ou seja, aquele espaço que imprime uma outra aceleração na reprodução capitalista. A sua constituição resulta da expansão de novas forças produtivas introduzidas por empresas e trabalhadores de posse de aparatos técnicos avançados, que se deparam com as populações locais, freqüentemente posseiros, pequenos proprietários, indígenas e antigos fazendeiros. Esse território do capital em transformação torna-se possibilidade do encontro de duas realidades distintas: a modernizadora, comandada pelos agentes do agronegócio que detêm as inovações tecnológicas e o uso do trabalho com base no assalariamento, e a da população local que se organiza sob outras estratégias de manutenção da vida, numa associação mais estreita com o tempo da natureza.

O espaço da fronteira nasce e se estrutura sob tensões, na medida em que se colocam em lados opostos os novos empresários personificadores do capital e as comunidades camponesas, indígenas e negras. Forma-se, então, um movimento cujas forças, comandadas pelos processos de aceleração de modernização, impõem-se às demais pelo uso de formas de violência que levam à exclusão do território do outro e com ele ao desaparecimento dos 
modos de organização da vida existentes anteriormente. Institui-se, assim, uma tendência à permanência de apenas um tempo do fazer e do viver, o tempo do capital, marcado pela anulação da diversidade e pela imposição de formas homogêneas de produzir ditadas pelo mercado. As relações capitalistas que se instalam, pautadas em outro ritmo de acumulação, representam nesses lugares a (re)criação de novas manifestações movidas pelas diferenças de estilos de vida e de riquezas gerando privilégios para alguns e exclusão para outros. Enfim, a fronteira é o lugar onde uma outra velocidade da modernização se instala produzindo, por conseguinte, distintas formas de crises.

A nossa tese, nesse sentido, é a de que o recente processo de aceleração da modernização nos cerrados piauienses motiva novas formas de reprodução do capital. Isso ocorre a partir da presença de novas mercadorias proporcionadas pela agricultura moderna, sobretudo a soja, mas também através da apropriação privada da terra rural e urbana, que se transforma em mercadoria valorizada geradora de riqueza também para alguns agentes do agronegócio. A base dessa reprodução, porém, se difunde pelo trabalho mobilizado e pelos mecanismos de não-simultaneidade econômica. Desse processo surgem novas modalidades de crises, quais sejam: a imposição do trabalho abstrato frente às formas concretas de reprodução da vida; o uso seletivo da terra produtiva; a grilagem de áreas devolutas, alterando as formas de uso, de comunitário para particular; a expropriação da população camponesa, mas sem transformá-la em assalariada porque não são concebidos postos de trabalho suficientes para a grande demanda de desocupados que passa a ocorrer; a exploração dos cada vez menos trabalhadores que conseguem alguma forma de ocupação, utilizando, para tanto, distintas formas de violência (subordinação do trabalho familiar, trabalho precarizado ou em condições similares ao escravismo etc.); e a degradação dos ambientes naturais. Esses elementos são, portanto, indicadores de que naquela área que se transforma em produtora de grãos os processos contemporâneos de modernização são significativamente excludentes.

Partindo dessa perspectiva, organizamos o trabalho em seis partes, ou capítulos, compreendendo discussões sobre a agricultura brasileira e suas novas formas de produção, principalmente, no que se refere à soja; a mobilização do trabalho, centrada na migração de sulistas; e as transformações 
espaciais que acontecem no campo e no urbano dos cerrados nordestinos, particularmente, do sul do Piauí.

Assim, o primeiro capítulo percorre os meandros da forma mercadoria, buscando entender de que maneira a soja contribui para a formação de novos revestimentos espaciais nos cerrados brasileiros. A modernização visando os cerrados e a soja contou com a participação do Estado nacional, que engendrou políticas, sobretudo, a partir de 1970, para tornar possível o projeto de ampliação de commodities para abastecer o grande mercado. O Estado foi fundamental para transformar as terras devolutas dos "gerais" em propriedade privada, ele próprio se colocando às vezes como especulador fundiário. A mudança da terra para a condição de mercadoria (portanto de capital) representou um passo importante para ocupação da fronteira agrícola e realizou o interesse daquelas áreas por parte de grupos sociais capitalizados $e$ das grandes empresas no sistema agro-alimentar brasileiro. A presença de tais empresas tornou-se crescente nos últimos anos controlando os processos de produção e de circulação de grãos, sobretudo a soja. Além de atuarem buscando a eliminação da concorrência, as empresas vencedoras se colocam também como agentes financiadores da produção agrícola moderna, atuando nos mesmos moldes do sistema bancário. As relações de monetarização que se estabelecem recentemente entre as processadoras de soja e os produtores agrícolas levam freqüentemente à subordinação desses últimos em relação às primeiras. O Estado, por sua vez, é o elo que complementa as condições para a reprodução do capital, seja regulamentando juridicamente as formas de relações demandadas pelo mercado, seja executando agregados de infraestrutura para atender as novas necessidades, seja, ainda, arcando com os novos custos sociais e ambientais que aparecem. A análise posterior dessas questões norteará as discussões em tal capítulo.

No segundo capítulo, preocupamo-nos em analisar como a agricultura moderna, liderada pela produção de soja, chegou aos cerrados nordestinos e quais as transformações empreendidas naquela região a partir desse processo. Tenta-se compreender a nova configuração espacial dos cerrados nordestinos, hoje sob o controle do agronegócio, bem como entender as dimensões dos impactos econômicos produzidos naquele lugar. No capítulo, analisamos duas sub-regiões dos cerrados nordestinos: o oeste da Bahia e o sul do Maranhão. 
No caso dos cerrados baianos busca-se entender o movimento inicial para promover a agricultura capitalista moderna, bem como, a presença dos sulistas que passaram a desembarcar naquela área nos anos 1980. Na seqüência, tenta-se identificar as transformações no urbano dessa sub-região, principalmente em Barreiras e no recém-emancipado município de Luis Eduardo Magalhães. Esse último, um antigo povoado habitado por sulistas que se converteu num importante centro urbano dos cerrados, tornando-se um suporte de comércio e serviços para a agricultura moderna. $\mathrm{O}$ crescimento econômico motivado pelo agronegócio, no entanto, não refletiu em melhoria nas condições de vida da população em geral, ao contrário, a expansão da "bonança" gerada pela agricultura moderna, apropriada por alguns, produziu uma ampla massa de excluídos no campo e no urbano dessa sub-região dos cerrados nordestinos. A expansão agrícola moderna do sul do Maranhão seguiu pelo mesmo caminho. Em Balsas e nos demais municípios sulmaranhenses, o crescimento urbano nos últimos anos produziu imensos espaços de segregação social. Neles surgem ilhas de riqueza, manifestadas em condomínios fechados habitados pelos representantes do agronegócio, circundados de uma periferia miserável habitada por antigos camponeses que perderam suas terras para as lavouras modernas e por migrantes de distintos lugares do Brasil, esperançosos pelas pretensas oportunidades de emprego, quase sempre inexistentes.

O trabalho mobilizado na figura do migrante sulista é o objetivo da análise do terceiro capítulo. Visamos entender as trajetórias percorridas pelos descendentes de imigrantes europeus desde o Rio Grande do Sul. A expansão contínua desse grupo em busca de novas terras para incorporá-las ao capital permitiu a formação de uma corrente migratória com ampla difusão pelo território brasileiro, ocupando principalmente áreas destinadas à agricultura moderna. Essa corrente chegou nos últimos anos nos cerrados piauienses e seus representantes são responsáveis, em grande medida, pelas mudanças empreendidas naquele lugar. Pretende-se, nesse sentido, apontar quem são esses migrantes que chegam ao Piauí e de que maneira ocorre o encontro do sulista com a população local, bem como as tensões que afloram de dois grupos regionais sulistas com formas distintas de pensar e de organizar seus espaços de vida. 
No quarto capítulo, nosso olhar se volta particularmente para os cerrados piauienses e a sua nova lógica de modernização excludente, alicerçada, contraditoriamente, no avanço dos aparatos técnicos produtivos modernos e na exclusão de seus antigos moradores, sobretudo os camponeses que habitam os "baixões". A expansão da agricultura capitalista moderna, que ocorre sobre as terras dos platôs planos, inicia-se nos anos de 1970 com uma ampla apropriação, comumente de maneira irregular, dos espaços de uso comunitário da população local. O suporte para a implantação dos primeiros grupos privados na recente ocupação dos cerrados piauienses foi garantido pelo Estado, que destinou recursos diretos, incentivos fiscais e terras para projetos agropecuários; às vezes, era o próprio Estado quem assumia a condição de expropriador e de especulador imobiliário, tratando de garantir uma nova etapa de modernização para aquela área, convertendo a terra em propriedade privada. Posteriormente, nos anos 1980 e 1990, esse processo se consolida nos cerrados piauienses com a instalação de novos migrantes sulistas e de empresas do agronegócio. A partir de então, a produção de soja no sul do Piauí teve importante elevação, apoiando-se nos sistemas agrícolas modernos, mas também na exploração aguda da força de trabalho da população local. Tenta-se, dessa forma, no capítulo, apontar as duas faces do capital que atuam produzindo polaridades sociais e econômicas.

O novo urbano sul piauiense que emerge do processo de modernização conduz as reflexões do quinto capítulo. Propõe-se analisar, por um lado, as velhas cidades dos cerrados e suas novas dinâmicas urbanas produzidas pela influência da produção moderna do campo. Nossa atenção se direcionará, especialmente, para as cidades de Uruçuí e Bom Jesus, onde ocorrem transformações importantes em seu urbano nos últimos anos, por conta de se firmarem como cidades do agronegócio no sul do Piauí. Procura-se, em seguida, analisar a formação de novos núcleos urbanos nos cerrados, surgidos para abrigar os novos produtores agrícolas da região. Cita-se aqui o núcleo urbano de Nova Santa Rosa, germinado a partir da instalação de migrantes gaúchos nos platôs planos. O uso dos gerais para formar áreas urbanas indica a configuração de uma nova lógica de ocupação daquele solo. Busca-se, assim, argumentar que as estratégias de acumulação lançadas pelo capital se refletem nas velhas e nas novas estruturas urbanas do sul-piauiense. 
O capítulo sexto trata da instalação da Bunge Alimentos no Piauí. A presença dessa grande empresa nos cerrados alterou substancialmente as relações de comercialização de grãos na região, na medida em que atua instituindo formas de monopolização na compra da soja, na venda de fertilizantes para os agricultores e, ainda, no financiamento das safras. Do mesmo modo, age adotando mecanismos que estimulam a degradação do ecossistema dos cerrados piauienses. A questão ambiental, aliás, configura-se como um grande problema para a região após a instalação ali do agronegócio. O avanço da agricultura moderna destrói não somente as espécies de flora e fauna e as nascentes dos rios existentes naquele bioma, mas também coloca em risco as vidas de pessoas, devido ao uso indiscriminado de agrotóxicos pelos produtores de grãos.

Essas são algumas das reflexões das quais se trata no presente texto, cujo intuito é o de colocar em discussão a imposição dos novos processos de modernização no sul do Piauí. Tenta-se identificar alguns dos condicionantes dessa modernização, responsável pelas transformações sócio-espaciais verificadas nos últimos anos na região. Dentre outros: a produção de mercadorias agrícolas para serem lançadas ao mercado e a mobilização do trabalho, que disponibiliza força de trabalho para a acumulação do capital.

Buscaremos, portanto, mostrar que a modernização atual que se instala no sul do Piauí apresenta um caráter ainda mais excludente do que a que havia anteriormente. Isso acontece principalmente porque as formas de expropriação vigentes não liberam somente trabalho para a exploração através do assalariamento, mas os sujeitos que se convertem em monetarizados não conseguem mais efetivar essa condição diante da impossibilidade de encontrar demandas suficientes que possam absorver sua força de trabalho. $O$ foco sobre as formas de exclusão produzidas pelo avanço da agricultura moderna, as quais atingem amplas parcelas da população no campo e na cidade do sul do Piauí, constituem um dos caminhos que se pretende trilhar nessa pesquisa.

Finalmente, é necessário considerar que os suportes para esse estudo foram obtidos também com os trabalhos de campo que realizamos nos cerrados nordestinos, particularmente no sul do Piauí. No período em que vigorou essa pesquisa, percorremos a região quatro vezes $(2002,2003,2005$ e 2006) com permanência média, em cada visita, de 30 dias, sendo que numa 
delas permanecemos três meses (de agosto a outubro de 2003). Esses trabalhos de campo permitiram acompanhar in loco a evolução da transformação daquela paisagem nos últimos anos. Possibilitaram também estabelecer contatos com distintos agentes econômicos envolvidos nesse processo, tais como os produtores e as empresas representantes do agronegócio; a população local moradora nas áreas urbanas e nas áreas rurais; os organismos oficiais do governo do estado e das prefeituras, além dos sindicatos patronais e de trabalhadores rurais. Esses contatos foram de extrema importância para a problematização das questões que aparecem no texto que segue. 


\section{1 - A SOJA E A FORMAÇÃO DA FRONTEIRA AGRÍCOLA NOS CERRADOS BRASILEIROS}

\section{1 - A expansão da produção de soja no Brasil e a manutenção do sentido agrário exportador}

A expansão da produção de soja para vastas regiões do território brasileiro, a partir da segunda metade do século $X X$, confirma que o país segue sustentando seu desenvolvimento apoiado na produção de mercadorias particularmente agrícolas para atender o mercado externo. Apesar da crescente importância dos componentes industriais na pauta de exportação brasileira de hoje ainda permanecemos, em grande medida, atrelados aos desígnios de país exportador de gêneros de alimentação. Tal fato indica que não nos desvencilhamos totalmente desse caminho construído desde a inserção do Brasil no sistema produtor de mercadorias com o advento da colonização portuguesa. As estruturas agrário-exportadoras, as quais fundamentaram as formas organizadoras do território brasileiro, persistem mesmo ocorrendo alterações das suas configurações no que diz respeito à apropriação das técnicas e das relações de trabalho.

A década de 1970 é um período de especial importância para a formação das características produtivas atuais do campo brasileiro, na medida em que houve naquele momento novas conjunturas econômicas, externas e internas, favoráveis à expansão agrícola moderna, destacando-se, dentre outras, a crescente urbanização e a crise do petróleo, esta última decretada nos primeiros anos 1970. O novo contexto mundial de aumento do consumo de novas mercadorias agrícolas (cana-de-açúcar, soja, laranja, trigo, café etc.) foi um elemento indutor importante para a formulação de políticas por parte do governo brasileiro naquela década, cuja execução visava garantir o abastecimento do mercado externo de alimentos; reduzir o impacto do aumento dos preços dos combustíveis fósseis, substituindo-os pelo álcool, da cana-deaçúcar; e, ao mesmo tempo, possibilitar a entrada no país de recursos financeiros para custear seu recente parque industrial. Além disso, a própria expansão da urbanização brasileira tornou-se um outro fator que obrigou o 
direcionamento de investimentos para a agricultura como atividade que sustentaria as demandas por alimentos colocadas internamente.

O crescimento da urbanização nacional não subtrai, entretanto, nosso sentido agro-exportador. A agricultura continuou recebendo um grande volume de investimentos públicos, concentrando-se, a partir de então, de maneira mais incisiva, naquelas culturas de maior inserção no mercado externo, ou naquelas voltadas para o mercado interno de combustíveis, como é o caso da cana-deaçúcar para a produção de álcool. Para promover a aceleração de uma agricultura modernizada foi institucionalizado nos anos 1960, o Sistema Nacional de Crédito Rural (SNCR) como forma de disponibilizar mecanismos legais para o financiamento do capital agropecuário, conforme nos esclarece Delgado (1982:34):

“(...) o processo de modernização [agrícola] somente encontrará dinamismo e abrangência significativa a partir de meados dos anos 60, até o final dos anos 70, quando a conjugação de um sistema financeiro apropriado - O Sistema Nacional de Crédito Rural; a implantação de novos blocos de substituição de importações de meios de produção para a agricultura patrocinada pelo II PND, e uma certa folga cambial nas transações externas possibilitam a introdução maciça das transformações na base técnica da agricultura".

As bases para o financiamento da agricultura moderna com decisiva participação de políticas públicas estavam criadas. O Estado passa a atuar como avalista incondicional dos grupos econômicos que se encarregariam de implementar novas tecnologias para a produção agrícola do campo. São eles os condutores, impulsionados pelas exigências do grande mercado interno e externo, dos novos processos produtivos, assim como os definidores de quais culturas a serem escolhidas em conformidade com os critérios de rentabilidade financeira que poderiam gerar.

A expansão da soja ocorre diante do novo contexto do mercado de alimentos do período pós Segunda Guerra Mundial, quando se ampliam as conjunturas favoráveis, principalmente no que diz respeito a outras formas de consumo dessa leguminosa. Contribuiu também para essa expansão a chamada "Revolução Verde" que, a partir da incorporação novos processos científicos, acelerou a produção agrícola e fomentou a adaptação do cultivo das plantas aos distintos ambientes naturais. Além disso, setores da indústria 
química, de mecânica pesada (para fabricação de tratores e máquinas agrícolas) e de aviação, que antes se voltavam para a fabricação de armamentos destinados à Segunda Guerra Mundial, passam a adequar suas estruturas industriais à agricultura, colocando à disposição dela técnicas inovadoras que impulsionaram o processo de produção agrícola. Para Brum (1988: 44):

"A Chamada 'Revolução Verde' foi um programa que tinha como objetivo explícito contribuir para o aumento da produção e da produtividade agrícola no mundo, através do desenvolvimento de experiências no campo da genética vegetal para a criação e multiplicação de sementes adequadas às condições dos diferentes solos e climas e resistentes às doenças e pragas, bem como da descoberta e aplicação de técnicas agrícolas ou tratos culturais mais modernos e eficientes. Através dessa imagem humanitária, ocultavam-se, no entanto, poderosos interesses econômicos e políticos ligados à expansão e fortalecimento das grandes corporações a caminho da transnacionalização".

A produção de soja se vale das inovações desses instrumentos para se generalizar na forma mercadoria, sendo a leguminosa escolhida para suprir as mudanças importantes no consumo de proteínas tanto para as pessoas quanto para os animais. Os EUA tornaram-se, no século $X X$, os principais produtores de soja e os responsáveis pela difusão em escala mundial de um "novo modelo de produção e de consumo" dessa leguminosa (Bertrand, 1987: 64). A adoção da torta de soja em combinação com o milho para ração animal, associando a proteína concentrada da soja com o teor energético do milho, será um componente importante da nascente agroindústria. Inicia-se, também nos EUA, a proliferação do uso de óleo de soja como matéria-prima para fabricação de margarinas e óleo de cozinha, substituindo outras substâncias graxas: as manteigas e as gorduras animais. A maior demanda gerou um substancial aumento da cotação da soja e de seus derivados no mercado internacional.

Os novos padrões alimentares, tendo como base os derivados da soja, espalharam-se pelo mundo despertando o interesse de vários países por esse emergente mercado, como foi o caso principalmente dos da América do Sul (destaque para Brasil e Argentina) que se lançaram como produtores dessa mercadoria agrícola a partir da década de $1960^{1}$. Nas décadas seguintes, a

\footnotetext{
${ }^{1}$ Havia anteriormente a produção de soja no Brasil, mas de maneira muito incipiente.
} 
expansão do cultivo na América do Sul elevou substancialmente o volume de produção mundial de soja, tornando-se, nos primeiros anos desse século, a principal área sojicultora, ultrapassando, inclusive, as tradicionais regiões continentais exploradoras de tal produto, como a América do Norte e Ásia (Siqueira, 2004). A possibilidade de participar desse lucrativo negócio internacional despertou o interesse dos grandes conglomerados econômicos por tal segmento da agricultura que despontava. As empresas de grande porte passam, assim, a controlar, com o apoio das políticas dos estados nacionais, a logística de armazenamento, de trituração, de comércio e de transporte da soja. Esse grupo de empresas assumirá as diretrizes para o aumento de produção, de comercialização e de consumo do produto. Além disso, ao ganhar a competição da produtividade pela força do dinheiro e pela mecanização, tornam-se as empresas vencedoras diante da concorrência, reinando monopolizando o mercado.

No Brasil, o avanço da soja ocorreu rapidamente; em praticamente três décadas de produção mais intensiva, o país passa a ocupar a segunda posição dentre o universo de produtores dessa commodity, sendo responsável atualmente por $28 \%$ da produção mundial. Nos anos 1990, o país amplia consideravelmente seus negócios com a soja e seus derivados, tornando-se fornecedor do produto para várias regiões do globo (mapa 01). O complexo da soja contribuiu ainda para elevar os índices da balança comercial brasileira nos últimos anos e sua inserção no mercado internacional. Em 2004, aproximadamente $10 \%$ das receitas cambiais do país provinha desse setor, 0 que representava, naquele ano, cerca de 10 bilhões de dólares. Tais valores decresceram, no entanto, em 2005, para cerca 8\% e 9 bilhões de dólares, respectivamente (Abiove, 2006). 
Mapa 01 - Principais Países Importadores de Soja em Grãos do Brasil - 2005

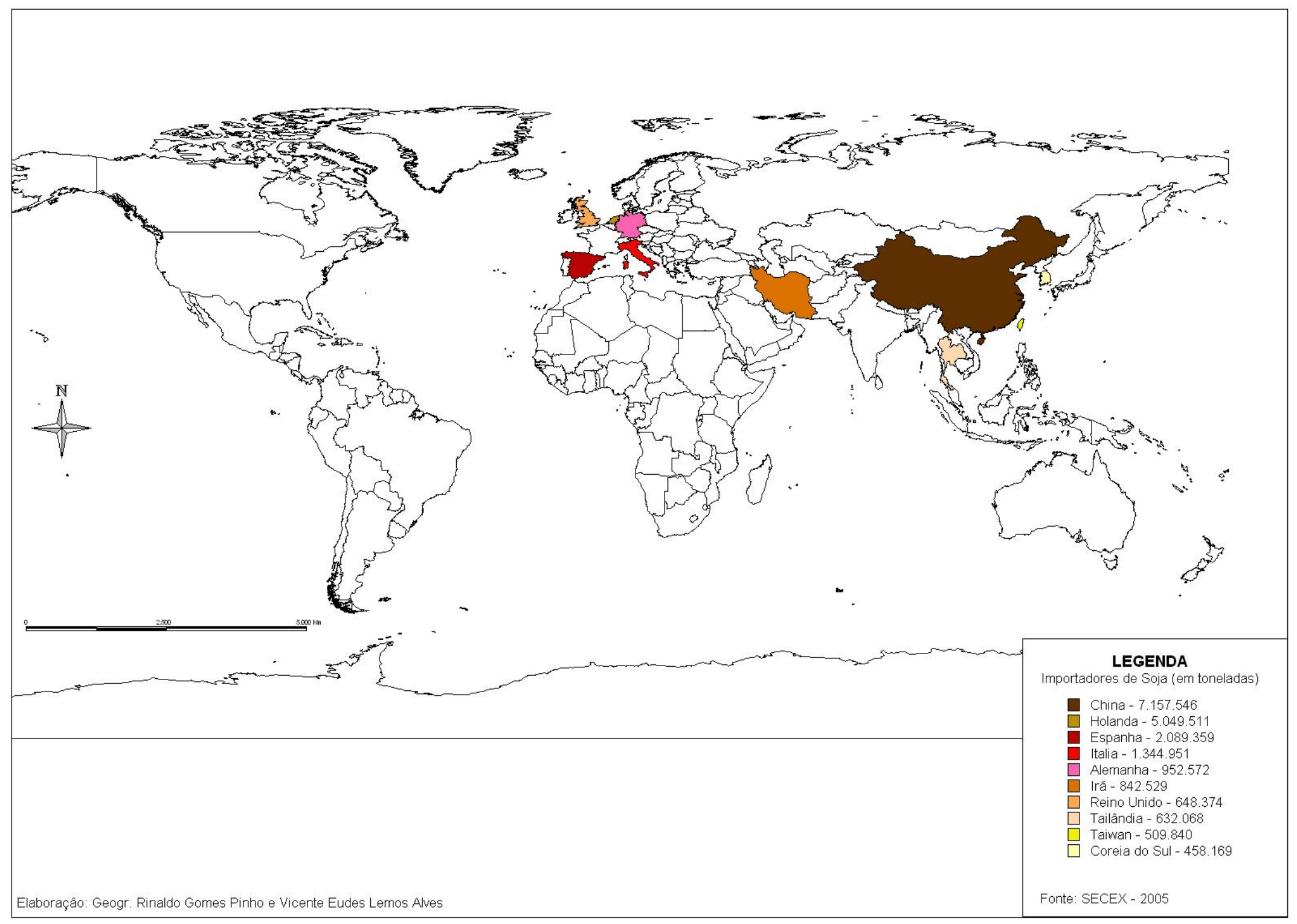


Desde os primeiros plantios no Rio Grande do Sul, na década de 1950, a soja superou a produção obtida por culturas mais tradicionais de nossa agricultura como o café, o algodão e o milho, indicando a transferência de prioridade do setor para aquela de melhor inserção no mercado externo. Nos primeiros anos do século $X X I$, a soja apresenta um predomínio absoluto sobre a quantidade produzida pelas demais culturas (gráfico 01), inclusive a do milho que compete nos mesmos segmentos da cadeia agroalimentar (ração, óleo e margarinas etc.). A superação numérica em valores de produção e de exportação, em comparação com outras commodities, indica atualmente a centralidade da soja no processo produtivo agrícola brasileiro. O predomínio da soja sobre outras culturas leva a uma certa tendência de homogeneização amplas parcelas do território brasileiro em razão do alto consumo dessa leguminosa.

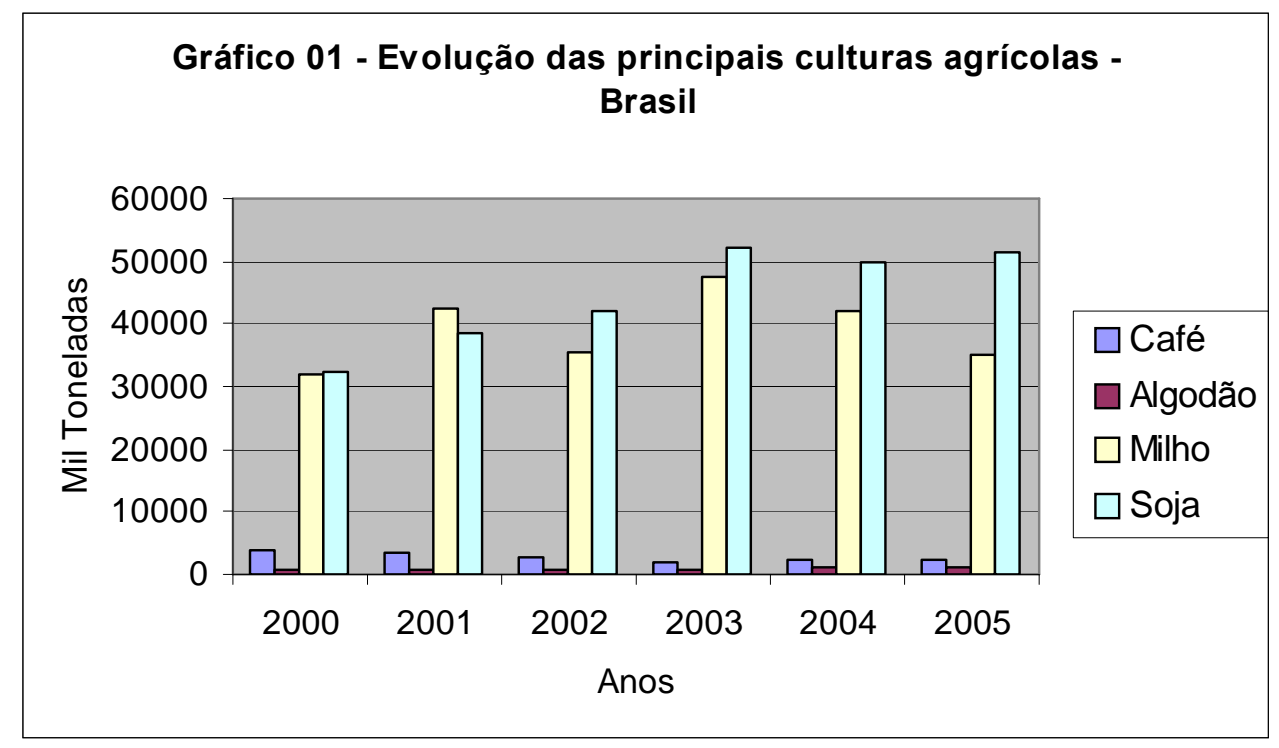

Fonte: Conab - Série Histórica de Grãos (safras 2000 a 2005) - IBGE - Produção Agrícola Municipal e Levantamento Sistemático da Produção Agrícola (Dezembro/05).

Apesar do uso de técnicas modernas do plantio à industrialização, as estruturas agrárias que envolvem a produção de soja se assemelham às de outras situações da história da agricultura brasileira em que as monoculturas se tornaram hegemônicas. É o caso, dentre outras, da cana-de-açúcar, do café e do algodão. Isto é, tais produções expandiram-se condicionadas pelas demandas do mercado externo, pela imposição de formas homogêneas de 
produção e pela associação com a grande propriedade fundiária rural, gerenciada por poucos agentes econômicos. A soja representa, desse modo, uma continuidade da não simultaneidade interna, na medida em que reproduz as formas fundamentais das estruturas de modernização vigentes no país em outros momentos cujas bases foram construídas sob a orientação do mercado internacional.

Para o crescimento da soja no Brasil, foi necessário o incentivo ao uso de tecnologias em maquinários e a pesquisas de laboratórios. Estas últimas tiveram a participação da Empresa Brasileira de Pesquisa Agropecuária (Embrapa), a qual assumirá, a partir da década de 1970, um papel de destaque na preparação das condições para o avanço da soja no território nacional, sobretudo desenvolvendo formas de melhoramento da produtividade e de adaptação dessa oleaginosa em distintos ambientes naturais. A preocupação em tornar a soja o principal produto agrícola brasileiro fez com que essa empresa estatal canalizasse recursos para pesquisas específicas, destinando um departamento da instituição e técnicos com alta especialização para desenvolver novos experimentos nessa área: trata-se da "Embrapa-Soja". Os substanciais investimentos financeiros nesse segmento da empresa foram um dos principais responsáveis pelo aumento de produtividade da soja brasileira, que passou de uma média nacional de $1.200 \mathrm{~kg} / \mathrm{ha}$, em 1970, para 2.208 $\mathrm{kg} / \mathrm{ha}$, em 2005. Quando se trata das regiões nas quais a soja chegou posteriormente, como nos cerrados do Centro-Oeste, esses valores são mais representativos. Nesse caso, a produtividade passa de $1.400 \mathrm{~kg} / \mathrm{ha}$, em 1977, para $2.900 \mathrm{~kg} / \mathrm{ha}$, em 2002². A “Embrapa-Soja” foi responsável, ainda, pelo desenvolvimento de novas espécies resistentes a pragas, mais adaptadas ao tipo do solo (arenoso ou argiloso) e ao tipo de clima $^{3}$.

É preciso considerar, entretanto, que o trabalho da Embrapa foi facilitado pelas políticas de extensão rural conduzidas pelos governos estaduais. Atribuise também o crescimento da produção de soja à formação de uma importante cadeia de interesses convergentes envolvendo o Estado, os agricultores

\footnotetext{
2 Informação da Companhia Nacional de Abastecimento (Conab), série histórica de produtividade.

3 Há campos experimentais de soja, da Embrapa, em áreas do semi-árido, indicando que nos próximos anos essa leguminosa poderá avançar sobre o bioma da caatinga.
} 
modernizados e uma variedade de empresas do complexo agroindustrial ${ }^{4}$, conforme nos esclarece Müller (1989: 110):

"A soja e a indústria da soja datam [no Brasil] de meados dos anos 60 e sua expansão vincula-se, indiscutivelmente, às modificações ocorridas no mercado mundial (fins dos anos 60), claramente, à demanda de grãos e farelos por parte da Europa. Assim, a ampliação das capacidades de esmagamento e de refino, secagem e estocagem por parte das empresas transnacionais e nacionais acham-se ligadas ao mercado internacional. Da mesma forma, a ampliação extraordinária da área de cultivo da soja, o predomínio da forma industrial de produzir a oleaginosa, o aumento da capacidade de armazenamento nas zonas produtoras, nos portos e indústrias bem como as modificações nos serviços financeiros e comerciais acham-se vinculados à demanda mundial".

A necessidade de aumentar as exportações para garantir o superávit na balança comercial proporcionando a continuidade de financiamento do capital industrial e, ao mesmo tempo, suportar a demanda por alimentos gerada pela crescente urbanização do país, pressionava o poder público a assumir uma parte da responsabilidade pela condução de políticas capazes de impulsionar a expansão agrícola. A soja transforma-se na principal cultura na tentativa de alcançar as metas de exportações, a qual deveria ser produzida prioritariamente no interior do Brasil, cujas terras poderiam ser mais facilmente aproveitadas para esse fim.

Para tanto, colocou-se em vigência políticas públicas de créditos, tal como, o Sistema Nacional de Crédito Rural (SNCR), além de outros incentivos estatais direcionados à modernização agropecuária. Os objetivos eram transferir recursos para médios e grandes produtores agrícolas e tornarem aptas regiões do território nacional para a produção agrícola em larga escala de culturas com melhor inserção no mercado externo. A atenção se voltava, principalmente a partir da década de 1970, para aquelas áreas que pudessem melhor articular os interesses de setores econômicos hegemônicos: disponibilizando terras a baixos custos para os grandes produtores e, ao mesmo tempo, abastecendo as empresas vencedoras com cultivos rentáveis

\footnotetext{
4 Segundo Brum (1988: 104), "Entende-se por complexo agroindustrial um conjunto de atividades econômicas - agrícolas, industriais, comerciais e financeiras - que apresentam elevado grau de integração entre si. Dentro desse conjunto de atividades a agricultura se encontra numa situação desvantajosa, dependente do sistema financeiro como também das indústrias de máquinas e insumos, das indústrias de transformação e das empresas de comercialização".
} 
financeiramente. As terras escolhidas abarcavam o território nacional das regiões do Centro-Oeste, Norte e Nordeste.

Os programas governamentais de apoio à expansão da agricultura modernizada destinada a tais regiões possuíam o caráter levantado acima e foram aplicados com vistas a ampliar a produção agrícola para exportação. Incluem-se nesses objetivos a criação do Polocentro, do Poloamazônia, do Polonordeste e do Prodecer (Programa de Desenvolvimento dos Cerrados). Esse último, um programa firmado em 1974, numa parceria entre os governos brasileiro e japonês, apresentava como meta direcionar capital de grandes empresas dos dois países para a modernização dos cerrados brasileiros (Oliveira, 2002). Tal programa foi um dos sustentáculos da expansão da soja em vários estados do Brasil e de apoio financeiro para agricultores que se dedicariam a essa cultura.

Com a soja os cerrados passam a receber atenção especial das políticas governamentais. Imaginava-se, até os anos 1960, que nesse bioma os solos possuíam poucas potencialidades para a agricultura. A presença de produção agrícola nele estava presente nos vales úmidos, mas tratava-se predominantemente de uma agricultura camponesa ${ }^{5}$ voltada, em grande medida, para o consumo da própria família. A pecuária extensiva era uma outra atividade econômica dos cerrados, praticada em complementação ou rivalizando com a pequena propriedade, haja vista que parte das fazendas de

\footnotetext{
${ }^{5}$ Nessa pesquisa adotaremos o conceito de camponês, como representando um grupo sócioeconômico com características específicas no que diz repeito à sua relação com o mercado e com a natureza. Trata-se de pequenos produtores que cultivam a terra (sua, arrendada ou apossada) com mão-de-obra familiar visando primeiramente a manutenção da família, sendo o excedente comercializado, mas sem que o lucro ganhe uma centralidade na condução das relações de produção e de trabalho. Na lógica de vida camponesa ainda se faz presente a ação do tempo cósmico que, em associação com as determinações religiosas, produz formas culturais arraigadas nas manifestações desses grupos. Embora, se reconhecerá aqui a permanência de formas de vida camponesas, enfocaremos que esse universo sofre as consequências dos novos processos de modernização e que também ele se organiza a partir do sistema produtor de mercadoria, apesar de regido por outros níveis de relações com o mercado. $\mathrm{O}$ avanço do mundo controlado pela forma mercadoria constitui um forte elemento de desarticulação dos modos de vida pré-existentes e uma convivência dessa população entre dois contextos distintos de reprodução da vida: o da unidade de produção que se mantém através do cultivo da terra e do uso de instrumentos com pouca tecnologia e o do mercado que funciona a partir da lógica do dinheiro e do trabalho assalariado. Desse modo, o camponês que produzia mercadorias para si e para o mercado, com o processo globalizado de modernização e com a expropriação dos seus meios de produção passa a oferecer apenas a sua própria força de trabalho como única mercadoria que pode ser por ele disponíbilizada. Transforma-se, nesse sentido, cada vez mais em individuos dependentes das regras comandadas pelo mercado.
} 
gado pertencia a grandes latifundiários. A partir da década de 1960 muda-se completamente de concepção e as terras de tal domínio transformaram-se nas preferidas para a expansão de novos processos de modernização capitalista, introduzidos pela agricultura portadora de maiores aparatos técnicos. Diante do interesse de grandes produtores pelos cerrados, articula-se o discurso no interior dos próprios órgãos estatais com vistas a substituir a agricultura camponesa e a pecuária extensiva por um agricultor dito moderno, este sim com estrutura de produção empresarial. Como fica claro na fala do então ministro de planejamento brasileiro, Reis Veloso, nos anos 1970:

"O cerrado não gosta da agricultura tradicional e sim de agricultura empresarial, com inteligência. Gosta de fertilizantes, de tecnologia avançada e de mecanização. É uma oportunidade que temos de modificar a estrutura da exploração agrícola no Brasil"".

As palavras acima indicam a maneira pela qual se desejava encaminhar as políticas públicas de ocupação econômica dos cerrados e a quem elas deveriam atingir. Ou seja, buscar-se-ia substituir o camponês cujas, técnicas de produção se julgava incompatíveis com os anseios da sociedade urbano industrial emergente no país, pelo agricultor ou pecuarista com maior sintonia às tecnologias mais modernas de produção no campo. Essas novas formas de produção agro-pecuária que se destinam aos cerrados não alteram, entretanto, os velhos vícios estruturais da sociedade agrária brasileira, baseados na concentração fundiária e na monocultura de exportação. A manutenção de tal estrutura ocorrerá sob as vistas do Estado, o qual se encarregou de financiar as agroindústrias, os agricultores e os pecuaristas de posse de outra velocidade de produção, surgindo daí um novo grupo de indivíduos que assumirá o comando do processo produtivo agrícola dos cerrados.

\footnotetext{
${ }^{6}$ Reis Veloso, depoimento citado pela revista Pastoral da Terra 2. Posse e Conflitos - estudos da CNBB (13), p.130, SP, 1976.
} 


\section{2 - As novas formas de financiamento agrícola nas décadas de 1980 e} 1990

O Estado que lidera o processo de modernização da agricultura brasileira nos anos de 1960 e 1970, construindo as principais bases para a implantação de novos processos de modernização no país, perde significativamente, nos anos 1980, parte do seu papel de fomentador, passando para o mercado ${ }^{7}$, representado pelas grandes corporações agrícolas, decisões importantes de tal tarefa. Não se aventa aqui, entretanto, o desaparecimento do Estado (como é pregado pelos defensores do neoliberalismo), em favor de um mercado total. Ao contrário, mercado e Estado resultam da formação do moderno sistema produtor de mercadorias, não sendo possível atuações de maneira autonomizada. Ocorre que no percurso de constituição desse sistema houve, ora mais ora menos, supremacia de um sobre o outro, mas na sua essência caminharam recuperando formas de reciprocidade, conforme nos esclarece Kurz (1998: 96):

“...) quanto mais a economia de mercado se expandiu estruturalmente, abrangendo toda a reprodução social e tornando-se o modo de vida universal, tanto mais a atividade do Estado precisava ser expandida. Estamos, portanto, diante de uma relação iniludivelmente recíproca".

No contexto atual da modernização, a maior participação do mercado como regulador da economia gera cada vez menos autonomia do Estado. Diante desse fato, o papel de guardião da poupança produzida socialmente torna-se retraído e em seu lugar surge um Estado que usa essa poupança para converter-se em empresário do próprio capital. A monetarização passa a ser, portanto, a saída para que o Estado possa cobrir os custos que recaem sobre

\footnotetext{
7 Para Polany (2000: 90), "Uma economia de mercado é um sistema econômico controlado, regulado e dirigido apenas por mercados; a ordem na produção e distribuição dos bens é confiada a esse mecanismo auto-regulável. Uma economia desse tipo se origina da expectativa de que seres humanos se comportem de maneira tal a atingir o máximo de ganhos monetários. Ela pressupõe mercados nos quais o fornecimento dos bens disponíveis (incluíndo serviços) a um preço definido igualarão a demanda a esse mesmo preço. Pressupõe também a presença do dinheiro, que funciona como poder de compra nas mãos de seus possuidores. A produção será, então, controlada pelos preços, pois os lucros daqueles que dirigem a produção dempederão dos preços, pois estes formam rendimentos, e é com a ajuda desses rendimentos que os bens produzidos são distribuidos entre os membros da sociedade. Partindo desses pressupostos, a ordem na produção e na distribuição de bens é assegurada apenas pelos preços".
} 
si em razão do volume de demandas de financiamento do capital privado e das despesas geradas pelos problemas sociais e ecológicos. O processo social emergente, nesse sentido, passa a ser mantido pela racionalidade do dinheiro, na qual apenas alguns podem ganhar. De acordo novamente com Kurz (1998: 186):

"Não se pode negar que essa economia historicamente nova acelerou de modo vertiginoso o desenvolvimento das forças produtivas. Mas todos os progressos científicos e tecnológicos têm de submeter-se à forma monetária e são por ela impregnados. Isso significa que o conteúdo sensível da produção é submetido a um procedimento econômico puramente quantitativo com uma aparência de lei física. A moeda trabalha como um robô social que não é capaz de diferenciar entre saudável e nocivo, feio e bonito, moral e amoral. Sob pressão da concorrência no mercado, o empresário é obrigado a obedecer, em todas as decisões, à racionalidade monetária. $A$ isso se dá o nome de economia empresarial".

Essa maior racionalidade monetária de escala global se instaurou também nas instâncias da vida econômica brasileira, como se verificou no sistema de financiamento rural brasileiro nos anos de 1980 e, principalmente, nos 1990. Os grandes grupos empresariais privados de distintos setores econômicos, aproveitando-se desse novo momento, tornaram-se também agentes de financiamento da produção agrícola brasileira. Destacam-se, dentre eles, os grandes conglomerados econômicos operantes no mercado financeiro, os quais controlam o comércio internacional agrícola. A escolha para investir seu capital, evidentemente, direciona-se para aquelas culturas que possibilitam maior rentabilidade monetária.

A década de 1980 é um marco importante na reestruturação das políticas agrícolas no Brasil (Graziano da Silva, 1996), quando o sistema de financiamento público para a agricultura diminui, em particular, a concessão direta de créditos e de subsídios. Em seu lugar surgem outras modalidades de créditos, inserindo dentre elas as mantidas pelo capital privado. O modelo anterior adotado a partir da institucionalização do Sistema Nacional de Crédito Rural (SNCR) deixa de ser paulatinamente aplicado diante das novas questões que se colocavam para a sociedade emergente, que passa a se orientar mais fortemente pelo neo-liberalismo. Gasques \& Conceição (2001: 100) apontam as 
transformações pelas quais passou o modelo de financiamento agrícola brasileiro nos anos 1990:

"Nos últimos anos houve mudanças profundas na forma de atuação do governo no crédito rural. Isso partiu da constatação, pela experiência, de que o modelo tradicional estava esgotado e apresentava vários defeitos, entre os quais a excessiva participação do Estado e a cultura dos subsídios. A realidade imposta pela necessidade de controle dos gastos públicos, em decorrência da política fiscal, e o esforço de modernização do Estado foram determinantes para que se fizessem alterações substanciais no padrão de atuação governamental".

A menor participação dos recursos advindos diretamente do Estado para o financiamento agrícola, não exclui, entretanto, o aporte financeiro público ao setor. As políticas públicas voltadas para a agricultura continuaram exercendo indiretamente o seu papel de financiadoras, principalmente concedendo isenção de tributação fiscal para os produtos agrícolas, sobretudo àqueles que atendem ao mercado externo. Os bancos oficiais ${ }^{8}$, como o Banco do Brasil e o Banco Nacional de Desenvolvimento Econômico e Social (BNDES), permaneceram concedendo crédito, mas agora sob regras estritas e mais ajustadas ao mercado. Além disso, mantém-se maior fiscalização e seletividade dos tomadores de empréstimos de recursos oriundos de financiamento agrícola. Não se reduz, todavia, o elevado índice de inadimplência do setor agropecuário junto aos bancos, principalmente aos oficiais. Estima-se que, nos anos 1990, a dívida acumulada pelos agricultores com o Banco do Brasil se aproximava de 24 bilhões de reais, concentrada, em quase sua totalidade, na camada dos grandes produtores (Helfand \& Resende, 2001). Observa-se, assim, que apesar da redução do papel do Estado, aportando diretamente seus recursos na atividade agrícola moderna, os prejuízos recorrentes desse setor acabam absorvidos pelo próprio Estado.

\footnotetext{
${ }^{8}$ Os bancos oficiais federais e estaduais aportavam, em 1999, $70,72 \%$ dos créditos concedidos por instituições ao setor agropecuário (68,32\%, federais e $2,40 \%$, estaduais), enquanto os bancos privados participavam com $23,26 \%$ dos empréstimos no setor, e as Cooperativas de Crédito Rural, 6,02\% (Gasques \& Conceição, 2001: 104).
} 


\section{3 - A participação das empresas processadoras de soja no sistema de crédito agrícola}

A redução do financiamento público direto na agricultura brasileira abriu espaço para que o capital privado assumisse, principalmente a partir dos anos 1990, parte do controle das transações financeiras desse setor. Das novas modalidades de créditos agrícolas passam a participar, além dos bancos oficiais, os bancos comerciais, as seguradoras, as empresas de comercialização agrícola e de insumos e as cooperativas. A participação dessas últimas avançou na segunda metade dos anos 1990, mas ocupa ainda uma parcela pequena do setor de financiamento agrícola brasileiro. A novidade, nesse caso, é o desenvolvimento de uma espécie de sistema de crédito rural solidário, o qual se organiza a partir de uma rede descentralizada e horizontal, sob administração de agricultores familiares e de organizações populares. Essas cooperativas de crédito participam na intermediação de financiamento à agricultura. O Sistema Cresol, denominação referente à forma como se estruturou tal sistema de cooperativismo de crédito rural, está amparado por lei federal e conveniado com o Banco do Brasil e o BNDES (Gasques \& Conceição, 2001). Esse sistema que se tornou, nos anos 1990, um referencial importante no direcionamento dos créditos para os pequenos e médios produtores possui, porém, uma participação ainda reduzida no universo de financiamento agrícola brasileiro: as Cooperativas de Crédito Rural participavam, em 1999, com 6,02\% das instituições que concederam crédito rural no país naquele ano (Gasques \& Conceição, 2001).

Outro segmento econômico que passa a atuar com concessão de créditos para a agricultura é o das empresas processadoras e comerciantes de produtos agrícolas e insumos. Além do controle de tais corporações sobre a comercialização e a industrialização de grãos, elas assumem também, a partir dos anos 1990, o papel de agentes financeiros, aproveitando-se do novo contexto de expansão do crédito rural privado brasileiro ${ }^{9}$. Nos últimos anos, houve uma importante inserção dessas empresas disponibilizando recursos

\footnotetext{
${ }^{9}$ Estimativas do Ministério da Agricultura apontavam que, em 2003, as tradigns participavam com cerca de $30 \%$ do total de crédito agrícola concedido ao setor. In: Folha de S.Paulo (Caderno Dinheiro), 11/04/2004.
} 
para financiamento de setores da agricultura nacional, principalmente para aqueles produtos que congregam melhor rentabilidade no mercado mundial.

O sistema de crédito rural mantido pelas agroindústrias segue os mecanismos de financiamento do setor bancário em geral, mas incorporando outras modalidades que elevam a subordinação do agricultor com a empresa credora. Nesse tipo de financiamento, o agricultor, ao adquirir dinheiro das processadoras através de empréstimo, firma compromissos de pagamento de juros nos quais, comumente, superam-se as taxas cambiais operadas no mercado financeiro. Além disso, ele se sujeita a outras obrigações, como as de entregar diretamente à empresa financiadora uma parcela importante de sua produção. A empresa, por conseguinte, é quem estipula o preço a ser pago pelo produto. A modalidade de crédito mais utilizada nesse caso é a que estabelece contratos com venda antecipada do produto cujo preço é fixado no mercado futuro, sistema conhecido como "Soja Verde". Nele, a empresa adianta recursos financeiros para o custeio da safra mediante garantias dadas pelo agricultor que podem ser de hipoteca, de penhor agrícola e de promissórias (Gasques \& Conceição, 2001). Além disso, nesse tipo de contrato é exigido do agricultor a aquisição de outros serviços ou produtos oferecidos pela empresa, compondo um pacote que inclui "dinheiro, fertilizantes, defensivos e serviços ao produtor, como análise do solo e agricultura de precisão" (Gasques \& Conceição, 2001:151).

O agricultor que não aceita participar desse sistema de subordinação dificilmente consegue permanecer como produtor de soja. Tal mecanismo empurra-no para uma freqüente dependência financeira às empresas, restando-Ihe poucas alternativas para comercializar seu produto fora do cerco do capital especulativo. A "venda casada" - como é conhecida essa modalidade exercida pelas empresas processadoras de compra de soja e financiamento do produtor - enquadra-se nesses mecanismos de controle mantidos pelas grandes empresas. O capital incorporado nas empresas vencedoras acumula, nesse sentido, nas duas pontas do negócio: compra-se o produto com preços abaixo dos que se pratica no mercado; financia-se a safra com juros superiores aos do setor bancário e, ainda, vende-se os insumos e outros serviços aos agricultores sem que estes exerçam a "liberdade" de buscar melhores condições para desenvolver sua lavoura. A relação do 
produtor com as grandes empresas, estabelecendo uma crescente subordinação do primeiro, amplia-se ainda mais pela grande dependência aos insumos industrializados, a qual a agricultura moderna se submete, especialmente as lavouras de soja ${ }^{10}$.

$\mathrm{Na}$ conjuntura econômica vigente, as grandes empresas do setor agrícola usam da estratégia de agente financeiro para a ampliação de seu capital. Os lucros são maiores quanto mais a empresa vencedora elimina seus concorrentes, reduzindo os raios de ação do produtor, através do cerco sobre a cadeia produtiva. A idéia, portanto, do status quo de que há uma democracia no mercado se anula diante das evidências de atuação dos grandes conglomerados econômicos. O que prevalece, nesse caso, é a ação destrutiva sobre os mais fracos e a imposição de formas de subordinação desses em favor de uma pequena parcela de empresas.

A maior participação do capital privado nos sistemas de financiamento agrícola que, a princípio, constitui uma fonte a mais de recurso para o setor, não representa, dessa maneira, uma solução para a produção alimentar brasileira, muito menos para garantir aqueles produtos de base da alimentação dos brasileiros. A grande empresa se interessa fundamentalmente pela agricultura moderna de exportação cujos retornos financeiros são mais imediatos. Isso ocorre em função da maior rentabilidade do comércio agrícola internacional e da possibilidade de disponibilizar financiamentos para aqueles agricultores com melhor estrutura econômica. Estes, portanto, estão mais propensos a contraírem maiores volumes de recursos financeiros a partir do sistema de crédito e são potencialmente melhores consumidores de derivados industriais vendidos por essas empresas, como é o caso dos insumos. A possibilidade das empresas perderem capital investindo nos setores agrícolas mais modernos é mínima, haja vista o fato dos riscos de insucesso serem repassados para o conjunto dos agricultores. Mesmo porque poucas delas se envolvem diretamente na produção, evitando-se, assim, situações que possam levar a prejuízos financeiros, como as de intempéries climáticas.

\footnotetext{
${ }^{10}$ Cálculos realizados para o estado do Mato Grosso indicavam que do total geral dos custos de produção nas lavouras de soja, o item insumos representava $51,75 \%$; sendo que dele a semente melhorada ocupava $10,60 \%$, e os outros componentes (fertilizantes, inseticidas e herbicidas) cerca de $41,15 \%$. Tais informações demonstram o grau de sujeição do agricultor frente as grandes empresas do complexo agroalimentar nas duas pontas do processo de produção (Bernardes, 1996:359).
} 
O sistema de financiamento dos produtores de soja mantido pela grande empresa privada é ilustrativo das formas de atuação desse capital, nelas se realiza o circuito completo de sua valorização através da forma mercadoria. Ou seja, agindo como especulador financeiro, efetua parte da circulação de seu capital; uma outra se faz quando se torna comercializador de matéria-prima agrícola ou de insumos e de serviços necessários ao funcionamento da agricultura capitalista; esse circuito se completa, enfim, com sua presença na esfera da industrialização e da comercialização de produtos elaborados; ademais, exercem o controle do sistema de logística.

Os mecanismos de valorização do capital dessas empresas, portanto, vão muito além de uma simples atuação na compra de matérias-primas e no seu processamento, mas se ampliam para todas as esferas existentes no circuito de valorização do capital. Inclusive o da exploração de mão-de-obra de seus trabalhadores diretos ou contratados através de empresas terceirizadas.

\section{4 - As empresas processadoras e a concentração de capital no circuito da soja}

Assim como o sistema de crédito agrícola com presença crescente do capital privado definindo os novos paradigmas de financiamento da agricultura, o setor agroalimentar como um todo sofreu os efeitos das transformações do processo produtivo do final do século XX. As novas demandas por alimentos,

principalmente os processados, exigiu das empresas elevados investimentos visando adaptar aos novos tempos os seus sistemas produtivo, administrativo e logístico. O avanço da sociedade cobrava de tais empresas não somente rapidez na elaboração e distribuição de suas mercadorias, mas mais oferta e variedade de produtos, o que demandava plantas industriais mais modernas, flexibilidade e capacidade de inovação (Belik, 1999). As grandes corporações econômicas do agronegócio, que desde a década de 1970 já controlavam uma fatia importante do setor agroindustrial (Bertrand, 1987), aproveitaram a nova conjuntura econômica de "mercado livre" e do acirramento da competição nos anos 1990 - colocando em dificuldades um grande número de empresas para concentrar capital, sobretudo nos países periféricos. Adotam, para tanto, estratégias agressivas de expansão econômica. Destacam-se, dentre elas, a 
associação com outros grupos hegemônicos nacionais ou internacionais do mesmo ramo de atividade. As fusões e/ou aquisições de outras empresas de distintos tamanhos, muitas delas com projeções nos mercados nacionais e regionais, consumaram o poder dessas empresas.

Consolidou-se, dessa forma, na agricultura brasileira, um mercado comandado por quatro ou cinco grandes empresas que, num primeiro momento, mesclava empresas nacionais e internacionais e, posteriormente, essas últimas assumindo o controle das operações do setor agrícola. A forma como tais grupos se organizam constituindo uma estrutura de concentração econômica é citada por Magalhães (1998: 119):

"Um atributo básico das estruturas de mercado é o número de firmas ofertantes no mercado e a distribuição das parcelas do mercado entre elas. Esse atributo é usualmente sintetizado por medidas de concentração econômica. Uma estrutura de mercado que apresenta alta concentração econômica é indicativa de que o padrão de concorrência se aproxima do monopólio ou de diferentes formas de oligopólio. É suposto que a concentração econômica seja um dos determinantes do padrão de concorrência de mercado; mais especificamente, uma alta concentração possibilita que as firmas adotem condutas de coalizão. O grau de concentração, observado empiricamente em um mercado, pode ter razões tecnológicas, devido à sub-atividade da função de custos, a qual ocasiona economia de escala e de escopo [Jacquemin, 1991, p.18-23], ou por exercício de poder de monopólio por parte das firmas estabelecidas, que constroem barreiras de entrada por diferenciação de produtos e por controle de fontes de suprimentos (Tirole, 1990, p.306)".

O setor de processamento de soja foi dos que mais sofreu com a reestruturação produtiva nas duas últimas décadas do século $X X$. Em alguns anos, as empresas multinacionais assumiram no Brasil (e em outros países da América Latina, como é o caso da Argentina e do Uruguai) o controle do setor, adquirindo as principais firmas responsáveis pelo armazenamento, industrialização e comercialização de soja e de seus derivados, e pela fabricação e distribuição dos insumos. Apesar das décadas de 1980 e 1990 tornarem-se referências importantes no sentido de detectar naquele momento uma intensificação na centralização do capital em poder de poucas grandes empresas, esse processo não nasce ali, mas é resultado do aperfeiçoamento das condições econômicas criadas pela "Revolução Verde" pós-1945, deixando livre o mercado de alimentos para atuação de empresas competidoras. Muitas 
delas, aliás, já se constituíam em conglomerados econômicos importantes, fundados ainda no século XIX e que exerciam grande influência nas decisões governamentais em seus países de origem (Brum, 1983). As imposições de novos padrões de consumo que surgem nos países centrais e se difundem para o restante do mundo serão a oportunidade dessas empresas de se expandirem para novos territórios nacionais.

Antes mesmo da década de 1960 já se notava a presença do capital internacional na agricultura brasileira direcionando o processo de aceleração do setor através do comércio de insumos, máquinas e implementos. Além de emitir os primeiros sinais de controle do mercado de grãos e de seleção do que se deveria produzir. A respeito dos primeiros grupos estrangeiros no setor agrícola brasileiro, instalados seguindo os preceitos da "Revolução Verde", Brum (1983:22) faz a seguinte colocação:

“(...) Dessa forma, na medida em que, a partir de 1945, aconteceu a entrada da modernização conservadora na agropecuária brasileira, por intermédio da 'Revolução Verde' comandada pelo grupo multinacional Rockfeller (este grupo tem participação em várias empresas no Brasil, dentre elas o Banco Lar Brasileiro, a Agroceres e a Cargill), as indústrias e os bancos passaram a dominar a economia do País, sugerindo inclusive o que deveríamos plantar".

A década de 1970 se destaca, no cenário agrícola brasileiro, especialmente porque ganha uma outra dinâmica, havendo um maior interesse das grandes empresas, por conta da participação das políticas públicas mais incisivas voltadas para a modernização da agricultura, sobretudo a de exportação e dos incentivos tributários para aquelas empresas que aqui se instalassem. A produção de soja avança no Brasil a passos largos, tornando-se o país, ainda naquela década, o segundo maior produtor mundial dessa leguminosa, perdendo somente para os Estados Unidos. Nos anos 1980 a soja já é a principal cultura de exportação brasileira (Bertrand, 1987), expandida pela expectativa de ocupar uma parcela do atraente mercado externo. Apesar da prioridade da política agrícola brasileira se destinar à produção de soja para exportação, verifica-se também um aumento do consumo dessa commodity no mercado interno, a partir dos derivados de soja menos atraentes a outros países, interessados mais no farelo e no produto in natura, como as margarinas e os óleos vegetais. Cresce também o consumo de farelo no país, decorrente 
da expansão das agroindústrias de aves e de suínos, gerando, portanto, maior demanda por rações (Espíndola, 1999). É com interesse nos segmentos do mercado externo e interno que tais empresas, a partir de então, ampliam suas investidas sobre a agricultura brasileira passando a controlar outros grupos econômicos situados nesse setor, ou ainda investem na construção de novas unidades de armazenamento e de processamento de soja no país.

A então Bunge y Born foi uma das grandes empresas a se instalar no território brasileiro. No início da década de 1980 esse grupo já controlava no país aproximadamente trinta empresas nos setores bancário (Banco Francês e Brasileiro), de insumos (adubos Serrana e Quimbrasil), de vestuário (Malhas Santista), de construção civil (Cimento Serrana e tintas Coral), de rações (SAMRIG) e de óleos e margarinas (SAMRIG). Incluem-se, ainda, nessa lista várias outras empresas associadas a seguros, a armazenagem, a moinhos etc. (Brum,1983). O patrimônio da Bunge no Brasil se ampliará nas décadas seguintes quando se torna aqui, e no mundo, uma das principais empresas do segmento de alimentos. Além da Bunge, estava sedimentada também a presença de outras multinacionais do setor de processamento e comércio de soja no Brasil, tais como: a Cargill (EUA), a ADM - Archer Daniel Midlands (EUA) e a Louis Dreyfus (FRA), controladora da Coinbra S.A.

Essas quatro empresas, que controlam mais de $60 \%$ do mercado mundial de soja (Castro, s/d), exportaram juntas, no ano de 2004, no que se refere ao comércio brasileiro de grãos e seus derivados, 5,7 bilhões de dólares, de um total de aproximadamente 10 bilhões de dólares que foram obtidos pelas exportações do complexo da soja. Participaram com 5,96\% do total das exportações brasileiras (Secex/Folha de S.Paulo, 06/03/2005). As estimativas apontavam que naquele ano esse seleto grupo de empresas concentrava $61 \%$ do total das exportações de grãos, farelo e óleo, e 59\% do esmagamento interno de soja (idem, ibdem). No grupo das grandes, a Bunge mantém a liderança no mercado de exportação agrícola brasileiro (participando, em 2004, com $2,64 \%$ do total das exportações do país), com quase o dobro da segunda colocada do setor, a Cargill, que participou com 1,49\% do total das exportações brasileiras.

A estratégia das grandes empresas de capital acionário sempre foi a de comprar os grupos econômicos nacionais do setor, mas sem, contudo, eliminar 
ou abandonar os suportes montados anteriormente pelas empresas adquiridas. Ao contrário, aproveitaram as estruturas deixadas por elas, tais como, a marca, que, em alguns casos, encontrava-se bastante sedimentada na sociedade brasileira, seja no nível nacional ou regional; as estruturas físicas e a carteira de clientes existentes. Essa fusão ou aquisição representou, entretanto, para a empresa incorporada total submissão às diretrizes do novo dono, o qual abandona as formas de gerenciamento existentes, comumente de base familiar, e impõe uma nova roupagem à empresa sob os preceitos de agilidade e flexibilidade, notadamente nas relações de trabalho.

A concentração do capital produziu efeitos também sobre o espaço geográfico na medida em que essas empresas passam a exercer um poder de pressão sobre os governos, que direcionam suas políticas para a formação de sistemas técnicos de aprimoramento da logística (Castillo, s/d), visando atender às exigências das empresas. O avanço desse capital que, até a década de 1990, concentrava-se principalmente naquelas regiões de maior infra-estrutura e de melhores condições de comercialização, como o Sul e o Sudeste do Brasil, passa a ocorrer também para as regiões que despontavam como grandes produtoras agrícolas ${ }^{11}$. Nesse caso, as grandes empresas se voltaram para as novas áreas de agricultura moderna tratando de controlar a cadeia produtiva de grãos. Todos os grandes grupos aqui mencionados instalaram nas novas fronteiras seus escritórios, silos ou plantas industriais nas principais áreas produtoras de grãos e nos portos de exportação ou nas "áreas troncos" de interligação dos modais de transporte. Além da construção de novas unidades, esses grupos adquiriram também as estruturas existentes, impossibilitando qualquer iniciativa de autonomia por parte dos produtores ou das empresas menores. Esse controle econômico do grande capital, que avança nos anos 1990 sobre novas regiões de produção agrícola moderna, é mencionado por Arroyo (2001: 204), para o caso dos cerrados do oeste baiano:

\footnotetext{
${ }^{11}$ A instalação de bases produtivas das grandes empresas nas novas regiões brasileiras de produção agrícola é motivada pela maior participação na produção de soja nessas áreas de fronteira que ganha espaço sobre os estados tradicionais de produção dessa commodity, no Sul do Brasil. No início dos anos 1980, por exemplo, somente o Rio Grande do Sul e Paraná participavam com $73 \%$ da produção nacional (Magalhães, 1998: 105). Na safra de 2004/05, a participação da região Centro-Oeste era de aproximadamente $55 \%$ da produção nacional, enquanto o Nordeste participa com cerca de $8 \%$ e o Norte, com 3\%. Em contrapartida, nessa mesma safra, a participação do Sul se reduz para aproximadamente $25 \%$ e do Sudeste para $9 \%$ (valores obtidos a partir do levantamento anual de safras realizado pela Conab).
} 
"Tais mudanças patrimoniais indicam uma ampliação da escala de operação de algumas empresas e, paralelamente, um provável aprofundamento da concentração de capital. Apontam, por sua vez, uma mudança na topologia de várias empresas e, sobretudo, uma tendência à formação de oligopólios territoriais. Tomemos, por exemplo, o caso do grupo Bunge e Born na região de Barreiras, na Bahia. Este grupo adquire, através da Santista Alimentos, o controle da Olvebasa - Vegetais, com uma planta de processamento de soja no município, e, posteriormente, passa a controlar a Ceval Alimentos, que já atuava na região através da sua planta industrial de farelo e óleo. Nessa porção do território, o grupo Bunge e Born concentra suas atividades, concorrendo apenas com a Cargill Agrícola, que localmente atua como comercializadora e beneficiadora de soja, sem possuir planta industrial. As possibilidades de uso do território são definidas, progressivamente, por um número menor de firmas".

Se, por um lado, a característica de atuação dos grandes grupos no mercado de soja é pelo viés da concentração de capital, impondo ao Estado um poder de pressão para que ele concretize políticas específicas que os beneficiem, por outro lado, os espaços onde as empresas se instalam passam a ser normatizados juridicamente de acordo com os interesses dos conglomerados. Com isso, busca-se garantir uma maior fluidez das informações e das mercadorias destinadas ao consumo. Afinal, é necessário ter competitividade do produto no grande mercado nacional e/ou internacional. O Estado, para tanto, continua exercendo o papel de financiador das infraestruturas físicas, adequando o espaço de produção às exigências de acumulação do capital. As ações estatais, efetivadas através da implantação (ou projeto de implantação) e melhoramento da logística de transporte, contribuíram sobremaneira para a formação de um sistema que torna mais efetiva a circulação das mercadorias nas áreas de expansão agrícola, elas somente se concretizaram após o interesse de grandes grupos econômicos pelos lugares onde se projeta a produção de mercadorias.

\section{5 - As formas de crise da soja}

O sentido da formação social e econômica brasileira, na sua essência, como nos lembra Prado Jr. (1965), foi o de fornecer produtos tropicais para outras nações. Esse sentido que acompanhou a história inicial de ocupação do 
território nacional ainda, em grande medida, prevalece nos dias de hoje, mesmo com a industrialização retardatária pela qual o país passou no século $X X$. As mercadorias agrícolas continuam organizando as formas da modernização contemporânea, num claro sinal de que o país ainda não se desvencilhou das amarras do passado, mesmo portando os instrumentos nos quais indicam sua participação na moderna sociedade industrial. O país que se insere no eixo da modernidade mundial não elimina o seu caráter de fornecedor de produtos primários: soja, ferro, algodão, café, carne bovina, milho etc. Apesar de que nas suas exportações aparecem também aviões, automóveis, celulares etc. Mas continua apto a mandar para fora alimentos, preferencialmente in natura. A soja é um desses casos; em algumas décadas o país se volta de "corpo e alma" para a produção dessa mercadoria aproveitando-se de seus preços favoráveis no mercado externo. Uma aposta como essa, entretanto, apresenta riscos importantes para a sociedade brasileira, pela fragilidade em que se sustenta esse setor. A riqueza decorrente de tal comércio parece ser fugaz, uma bolha de crescimento econômico que parece já se desfazer diante das oscilações negativas de compra de grãos por parte do grande mercado consumidor internacional, que se pauta pela competição. Isso, aliás, é bastante corrente em outros momentos da história nacional cuja decisão de priorizar um produto primário para exportação se devia comumente à expansão da demanda do mercado externo. Com a diluição dessa demanda a crise se instala levando à decadência de áreas até então dinâmicas economicamente. Tais situações foram recorrentes não somente no período colonial cujo espaço de produção estava subordinado à metrópole, quem verdadeiramente definia o que se deveria produzir na colônia, mas se sucederam posteriormente quando já havia a constituição de uma nação desvinculada politicamente do poder de Portugal. Citam-se aqui os momentos efêmeros de aceleração da modernização através da produção de borracha, na Amazônia; de algodão e de cacau, no Nordeste brasileiro. Até mesmo o do café, que, embora tenha deixado como herança a industrialização de São Paulo, produziu crises, após sua passagem, em amplas regiões fluminenses e do próprio estado paulista. O sentido exportador de matériaprima, portanto, continuou prevalecendo no horizonte da sociedade brasileira. As estruturas fundamentais de organização espacial também sofrem desse 
mal, como se percebe na logística de transporte em tempos passados que se repetem atualmente. O exemplo novamente provém de São Paulo. O café permitiu a formação de uma rica e diversificada malha ferroviária interligando áreas produtoras ao sistema portuário paulista. Essa logística se desfez, todavia, logo após o esgotamento da tentativa de homogeneização das formas de reprodução capitalista através do café, isso já no século $X X$. Para entender porque regiões que se tornam dinâmicas não se alongam por mais de alguns anos ou décadas, novamente Prado Jr. (1965: 07) nos oferece a chave para o desvendamento dessa lógica. Trata-se de falhas nas nossas estruturas que permanecem inalteradas mesmo fazendo parte de um novo processo de acumulação capitalista, continuam, portanto, vinculadas ao passado colonial, num movimento continuo de descompasso:

"Analisem-se os elementos da vida brasileira contemporânea; 'elementos' no seu sentido mais amplo, geográfico, econômico, social, político. O passado, aquele passado colonial que referi acima, aí está, e bem saliente; em parte modificado, é certo, mas presente em traços que não se deixam iludir. Observando-se o Brasil de hoje, o que salta a vista é um organismo em franca e ativa transformação e que não se sedimentou ainda em linhas definidas; que não 'tomou forma'. É verdade que em alguns setores aquela transformação já é profunda e é diante de elementos própria e positivamente novos que nos encontramos. Mas isto, apesar de tudo, é excepcional. Na maior parte dos exemplos, e no conjunto, em todo caso, atrás daquelas transformações que às vezes nos podem iludir, sente-se a presença de uma realidade já muito antiga que até nos admira de aí achar e que não é senão aquele passado colonial. (...) Numa palavra, não completamos ainda hoje a nossa evolução da economia colonial para a nacional".

Apesar da ampliação, nas últimas décadas, do mercado nacional, motivada principalmente pela industrialização, e do distanciamento temporal do colonialismo, a dedicação extremada à produção de soja indica que a sociedade brasileira permanece no atual período como em outros tempos atrelada às demandas do mercado externo. Assim como ocorreu com as demais culturas agrícolas de expressão econômica no passado, a soja ocupa vastas áreas do território nacional que se tornam momentaneamente pujantes, produz os novos ricos do interior do Brasil, reorganiza o poder econômico e/ou político tomando, pela concorrência, a posição de centralidade antes mantida por outras áreas da esfera regional. Esse vigor econômico, entretanto, é fugaz, 
prevalecendo enquanto existe a demanda do mercado externo ou enquanto durar o interesse do capital pela produção de determinadas mercadorias. Quando ela desaparece ou arrefece não sendo mais possível manter a valorização elevada do capital tais áreas são abandonadas à própria sorte, ou servem de base para a construção de um novo processo de acumulação capitalista, sustentado em outra mercadoria de interesse do mercado.

Por enquanto a soja ainda é o produto que lidera a produção de riquezas nos novos espaços brasileiros de ocorrência do agronegócio, cujas exportações realizadas pelas grandes empresas sustentam um certo dinamismo local. Mas, o arrebate econômico não se mostra muito duradouro, visto que esses espaços continuam exercendo o papel de produtores de gêneros agrícolas para exportação, dependentes, portanto, das condições incertas do mercado.

A pauta de exportação brasileira no que diz respeito ao complexo da soja (gráfico 02) deixa evidente que o país, apesar de se manter também no comércio de derivados agrícolas industrializados (sucos, açúcar, álcool etc.), participa do mercado mundial, no segmento econômico da agropecuária, como simples provedor de matéria-prima ou de produtos semi-industrializados (Oliveira, 2004). Verifica-se que nas vendas para o mercado externo de soja e de seus derivados predominam amplamente os grãos in natura e o farelo, indicativas das deficiências em incorporar o processo de transformação industrial para as matérias-primas que produz. Essa situação se agrava com a participação das empresas vencedoras do setor agrícola, pois são elas as tomadoras de decisões sobre os produtos apropriados para exportação. São escolhidos, evidentemente, de acordo com sua capacidade de produzir lucros para tais empresas. 


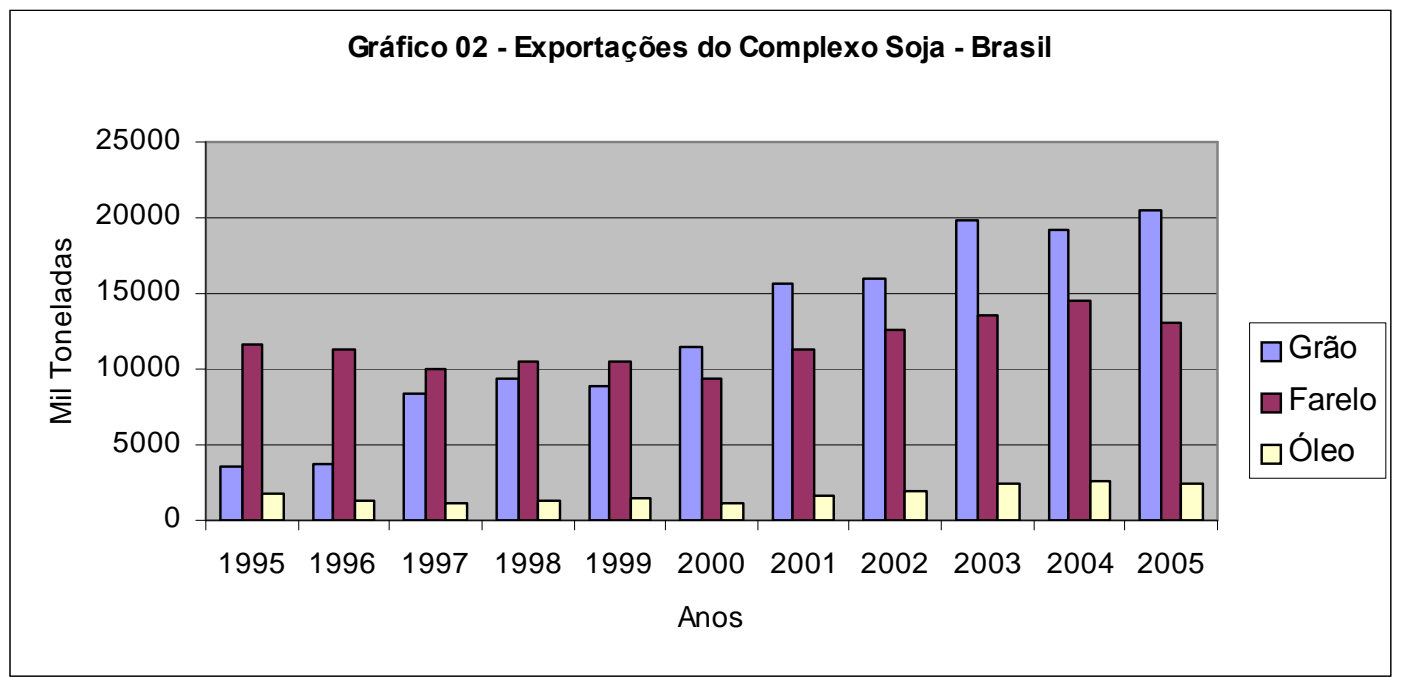

Fonte: Associação Brasileira das Indústrias de Óleos Vegetais - ABIOVE, 1995-2005.

O desempenho da soja na balança comercial brasileira demonstra, no entanto, que essa commodity sofre os primeiros reveses desde de que assumiu a liderança na pauta de exportações do setor agrícola nacional alcançada nas últimas décadas. $\mathrm{O}$ abastecimento em níveis elevados do mercado mundial decorrente do aumento da oferta do produto nos tradicionais países plantadores e a entrada de novos países concorrentes nesse mercado reduziu os preços gerais da soja e de seus derivados (gráfico 03). Em contrapartida, os insumos agrícolas industrializados aumentaram de preço em função da maior demanda, favorecendo as grandes empresas de fertilizantes, mas produzindo perdas financeiras generalizadas aos produtores, ampliadas também pela valorização da moeda nacional frente ao dólar. Em 2005, em comparação com 2004, o agronegócio brasileiro registrou uma queda de 4,66\% do PIB (Produto Interno Bruto) no setor, sendo a agricultura a que apresentou as maiores perdas, de $15,46 \%$. A soja foi a que mais contribuiu para o agravamento da crise no setor, seu faturamento caiu de $R \$ 35$ bilhões, em 2004, para $R \$ 24,7$ bilhões em $2005^{12}$.

\footnotetext{
${ }^{12}$ Folha de S.Paulo, Caderno Dinheio (18/03/2006). Fonte consultada pelo referido Jornal para divulgação das informaçõies: CNA (Confederação da Agricultura e Pecuária do Brasil).
} 


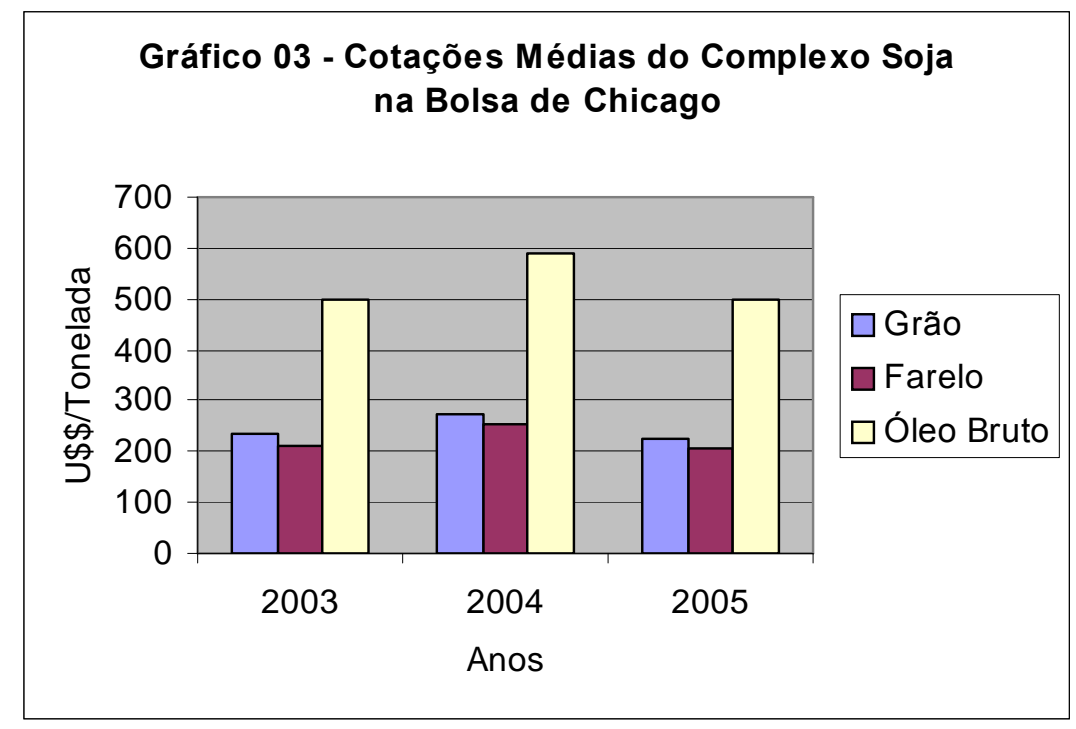

Fonte: Associação Brasileira das Indústrias de Óleos Vegetais ABIOVE, 2003-2005.

Os problemas da soja tornam-se mais evidentes quando analisados no conjunto da cadeia agroalimentar cujas perspectivas reais de uma crise global de grandes proporções são anunciados. O segmento de produção animal, por exemplo, importante consumidor do farelo de soja, está ameaçado de desmoronar-se diante do avanço de várias doenças que afetam o desenvolvimento da bovinocultura, avicultura e suinocultura. A denominada "gripe aviária" é a que oferece maior impacto negativo no setor devido a possibilidade de redução drástica da produção e do consumo de aves. A crise nessa atividade produzirá certamente reflexos imediatos sobre a cadeia da soja, visto que sua transformação no principal produto agrícola no mercado mundial deveu-se ao fato de o farelo tornar-se matéria-prima básica para ração animal.

O cenário desfavorável que se anuncia para a soja não se deve, entretanto, apenas a uma situação de adversidade epidemiológica que, se confirmada, representará um colapso sem precedentes na agroindústria. Há também uma indicação de queda de consumo per capita de proteínas animais nos países desenvolvidos que, com o declínio da taxa de crescimento populacional no mundo, implicará redução no consumo de soja e de outras oleaginosas. 
Apesar do sinal de que está se chegando no limite o consumo de soja como produto alimentar e de que há excesso de oferta do produto no mundo nesse momento, parece que a produção dessa leguminosa continuará crescendo nos próximos anos. As previsões indicam que entre 2015 e 2020 a produção de soja deverá atingir a cifra de 335 milhões/ton., ante a produção aproximada de 200 milhões/ton. atualmente. Os países da América do Sul, principalmente o Brasil, contribuirão com parte significativa desse montante (Dros, 2004).

A saída que se anuncia para continuar produzindo soja em larga escala e que, em 2006, está despertando o interesse dos grandes agricultores e das grandes empresas processadoras do produto, é o uso dessa leguminosa para a produção de biodiesel. $\mathrm{O}$ aproveitamento da soja como matriz energética já movimenta as indústrias hegemônicas do setor no sentido de controlar o processamento e a comercialização dessa matéria-prima também no segmento de combustíveis. Esse novo mercado que desponta realça o movimento das empresas em busca de maior lucratividade, inclusive, colocando como possibilidade a substituição ou a adaptação de suas atuais plantas de produção de óleos comestíveis passando para a fabricação de combustíveis.

Os sinais de crise da sojicultura superam, entretanto, as questões aqui apontadas e já se anunciavam pela maneira como o agronegócio se apropriou dessa mercadoria para elevar os seus lucros. No Brasil, assim como nos demais países produtores, a soja se espalha produzindo diferentes matizes de crise. A sua expansão representou um elevado custo sócio-ambiental. O ambiente natural apresentou grandes impactos negativos causados por uma cultura que avança sobre a vegetação nativa reduzindo drasticamente as formas de diversidade natural ali existentes. O crescimento do cultivo de soja ocorreu mediante a conversão de mais áreas naturais, sobretudo os cerrados, em espaços de produção agrícola moderna, impulsionando o desmatamento. Esse problema torna-se mais grave quando se prevê que a soja avançará sobre novos territórios brasileiros (mapa 02) onde hoje o custo de produção é menor, atraindo mais produtores e novas unidades das grandes empresas, ao passo que as tradicionais áreas de produção são aos poucos descartadas em razão dos maiores custos e do fato do ambiente natural se apresentar, em grande medida, degradado. Cita-se aqui, para o primeiro caso, os estados do 
Maranhão, Piauí, Bahia, Tocantins, Pará, Rondônia, Amazonas e Roraima; para o segundo, os estados da região Sul, ou mesmo os do Centro-Oeste. Estes últimos, apesar de ainda indicarem um processo de expansão das lavouras de soja, já não correspondem mais a áreas de grandes atrativos econômicos, como aparecem atualmente os cerrados nordestinos e as de floresta ou de transição destas, como na região Norte do país. Conta-se, ainda, os impactos sobre o solo através da contaminação pelos pesticidas e um aumento substancial dos processos erosivos, provocando assoreamento dos principais rios, além do desaparecimento de seus mananciais. 
Mapa 02 : Produção de Soja no Brasil, por Município - 2005

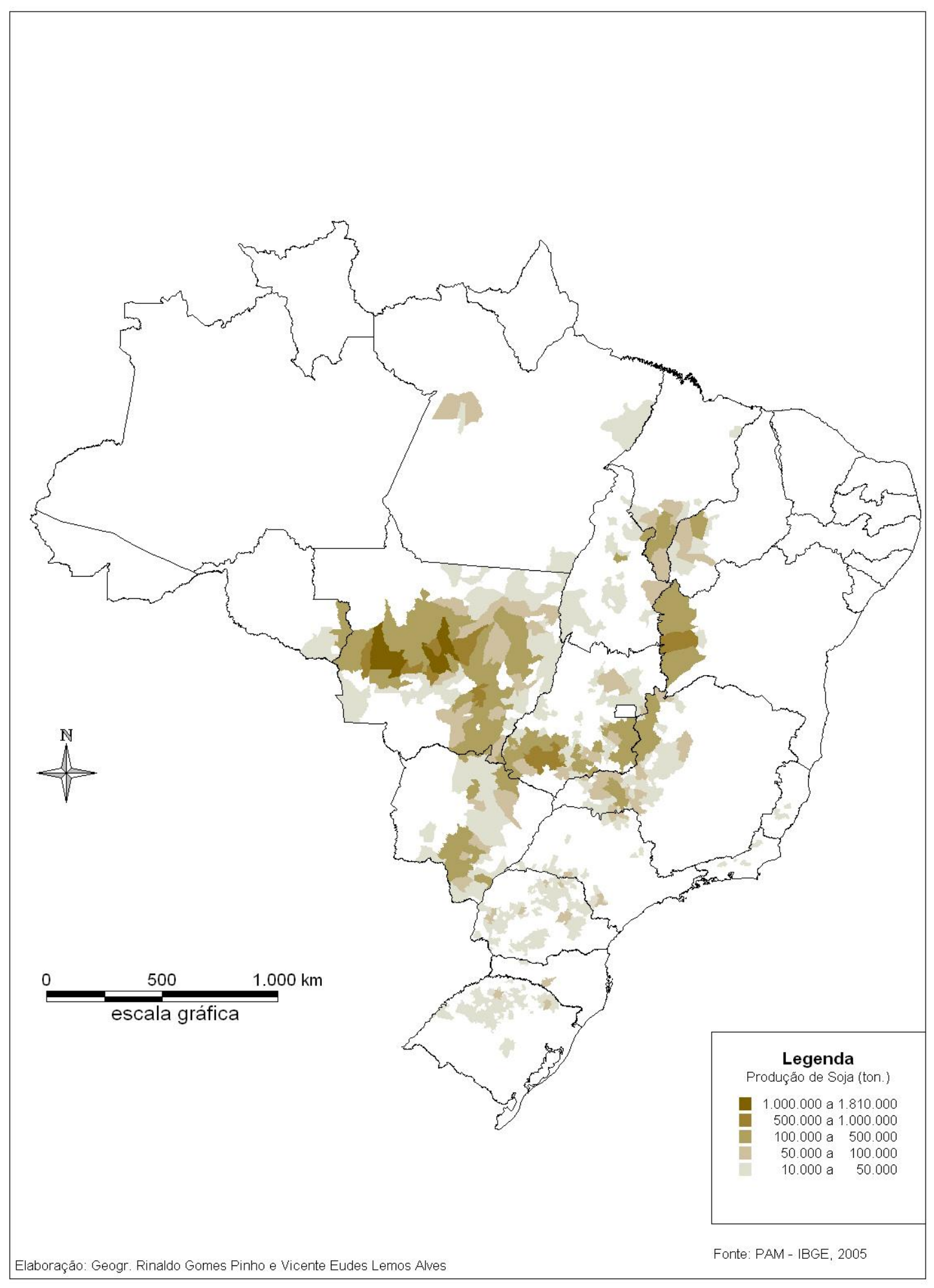


O clima também sofre importantes alterações com a expansão da soja. As áreas ocupadas com essa cultura vêm se observando mudanças tanto na temperatura, ocorrendo elevações, quanto no regime de chuvas, com reduções dos índices pluviométricos ${ }^{13}$. Além dos impactos negativos provocados diretamente pela expansão da agricultura moderna, principalmente a soja, pode-se incluir também os decorrentes da instalação de infra-estrutura necessária para que o agronegócio se realize. Destaca-se, por exemplo, a construção do sistema de escoamento (rodovias, estradas de ferro, hidrovias etc.) para o qual se desmata grandes extensões do território.

A crise da agricultura moderna que recai sobre o ambiente natural ocorre também no social. A expansão do agronegócio, em particular da soja, gerou múltiplas formas de tensões sociais, como o aumento dos conflitos agrários. $\mathrm{O}$ estado do Mato Grosso, por exemplo, tornou-se o estado brasileiro campeão de índice de violência (Porto Gonçalves \& Lacerda, 2004). É possível apontar os reais motivos de por que ocorre, em áreas inseridas num contexto de fronteira agrícola, uma proliferação de conflitos no campo e na cidade. Dentre outros fatores, a expansão da soja produz: a) desemprego, visto que a produção se faz prioritariamente com máquinas e não com pessoas, causando, por conseguinte, êxodo rural; b) expulsão de posseiros de terras devolutas, como se constata nos últimos anos pela elevação do número de população que perdeu seus antigos lugares de moradias e de produção, ocupadas pelas lavouras modernas; c) apropriação irregular e concentração da propriedade da terra pelo agronegócio, sempre acompanhada de violência praticada contra comunidades de posseiros e índios; d) contratação do trabalho em condições de precarização absoluta ou até mesmo em condições análogas à escravidão mantidas pelas empresas do agronegócio; e) desaparecimento dos espaços naturais imprescindíveis para a manutenção das comunidades locais.

As questões levantadas acima são indicadores da crise que se configura em diferentes dimensões no espaço da fronteira. Tal afirmação será identificada de maneira mais contundente a partir do próximo capítulo, quando analisaremos mais detidamente uma região específica de expansão do

\footnotetext{
${ }^{13}$ Nobre, Carlos A. (et al.) - Mudança Ambiental no Brasil. In: Scientific American (Brasil). Edição Especial (Terra na Estufa), n 12, 2006.
} 
agronegócio liderada pela soja, qual seja, os cerrados nordestinos e, em particular, os cerrados piauienses.

\section{6 - A disputa capitalista pelas terras dos cerrados, antes e depois da expansão da soja}

A realização dos processos de aceleração da modernização brasileira, sustentada na produção soja, somente se tornou viável mediante a existência de novas frações de áreas disponibilizadas para uma maior valorização do capital. Essas terras que servem de apoio à produção de uma nova mercadoria agrícola também se transformam em bens valorizados, através da sua conversão em meio de produção para os novos proprietários. Estes retiram delas renda fundiária, mesmo não as colocando para produzir. A terra monopolizada nas novas áreas de expansão da agricultura moderna torna-se, portanto, recurso estratégico para acumulação do capital. Essas porções de áreas incorporadas ao capital respondem, portanto, às condições concretas de realização do valor. A apropriação privada da terra é um dos complementos do que Marx (1968 [1894]: 937) considerou como uma forma jurídica que permite a ampliação da renda do capital, que juntamente com os juros e o trabalho assalariado compõem a denominada Fórmula Trinitária, como nos esclarece:

"Capital - juro; propriedade fundiária, propriedade privada da terra, no sentido moderno, correspondente ao modo capitalista de produção - renda (fundiária); trabalho assalariado - salário. Nessa forma encontrar-se-ia, portanto, a coesão entre as fontes das rendas. O capital, o trabalho assalariado e a propriedade fundiária são formas sociais historicamente determinadas, respectivamente, do trabalho e da terra monopolizada e ambas estão em correspondência com o capital e pertencem à mesma formação econômica da sociedade".

A aceleração da modernização na fronteira agrícola brasileira segue a lógica de valorização do capital explicitada por Marx, na medida em que a apropriação privada da terra nessas áreas representa, para as empresas e para os produtores de mercadorias agrícolas, um dos pilares de sua acumulação capitalista. $\mathrm{O}$ avanço das estruturas de concentração de terra e de renda sustentadas na agricultura exportadora aprofunda os processos internos de não simultaneidade capitalista. Ou seja, a presença do capital, que impõe 
maiores velocidades de produção nessas áreas, gerou movimentos que expressam formas não homogêneas no novo contexto de vida do espaço da fronteira. Os mais modernos sistemas técnicos, capazes de alterar as condições da natureza para obter melhores resultados na produção agrícola ou de tornar possível a unificação do tempo local com o global através dos sofisticados meios de comunicação, sobrepõem-se às estruturas de modernização anteriores que ainda persistem ou são reorganizadas para atender à modernização contemporânea. Esses dois movimentos que se confrontam (o da grande propriedade com presença da agricultura cientifizada e o da pequena propriedade camponesa produzindo em escala familiar) são os principais geradores de tensões na fronteira agrícola.

Antes da instalação da agricultura capitalista moderna as terras dos cerrados brasileiros (mapa 03) eram utilizadas para diferentes usos da população local de maneira privada ou comunitária. A produção camponesa e a pecuária extensiva de base mais mercantil rivalizavam a posse daquelas áreas a partir de usos sobrepostos ou complementares. Aproveitavam os recursos disponíveis nesses domínios para se reproduzir, seja a partir da forma mercadoria, como ocorria com os grandes e médios fazendeiros agricultores e pecuaristas, seja para manter a sobrevivência como no caso dos camponeses posseiros ou pequenos proprietários que praticavam uma agricultura incipiente e/ou, alguns deles, atividade criatória com reduzidos rebanhos. O uso da terra dos cerrados para ambos os grupos ocorria aproveitando as características ecológicas encontradas em tal domínio, que, de modo geral, organizam-se em dois conjuntos topográficos com características geomorfológicas particulares, mas que se complementam: os platôs planos (chapadas ou gerais) e os vales úmidos. As características naturais fundamentais dos cerrados, que apresentam poucas variações em toda a sua extensão, são descritas por Waibel (1979: 194) em sua visita ao Planalto Central brasileiro:

"A topografia predominante do Planalto Central é a de uma região horizontal, chata, que me fez recordar muito o Planalto Central da África do Sul; o mesmo horizonte circular, a mesma vegetação baixa e rala, que permite à vista varrer extensões infinitas. Podem-se distinguir claramente dois níveis. Um mais alto, com cerca de 1.000 a 1.100 metros, forma os espigões divisores entre os cursos d'água, muitas vezes eles são quase horizontais e não mostram qualquer sinal de erosão. Estes espigões planos são chamados 'chapadas' 
quando se estendem entre rios menores e 'chapadões' quando formam os divisores de águas entre os rios principais. Chapadas e chapadões são separados uns dos outros por vales largos, achatados, que a altitudes entre 700 e 900 metros formam o segundo nível de paisagem do planalto. Enquanto nas chapadas prevalecem as formas convexas, as formas côncavas predominam nos vales, em longas encostas que descem suavemente das bordas dos espigões até os talvegues dos rios e córregos".

Nesse conjunto que compõe a geomorfologia dos cerrados, nas terras úmidas que aparecem nos vales a presença humana predomina, principalmente, nas proximidades dos rios perenes onde a agricultura familiar se desenvolve. Os grandes vales, atravessados por um rio importante, são intercalados por vales menores e mais isolados. Estes últimos recebem freqüentemente denominações de "baixões" ou "vãos" e possuem uma ocupação intensa de posseiros que aproveitam das riquezas naturais dessas áreas para desenvolver distintas formas de uso. A presença de água e de solos com maior fertilidade natural que poderiam ser aproveitados tanto para a agricultura quanto para a formação de pastagens fizeram dos "baixões" lugares disputados por camponeses e latifundiários, gerando historicamente entre eles tensões permanentes por sua posse. 
Mapa 03: Localização do Bioma Cerrado no Brasil

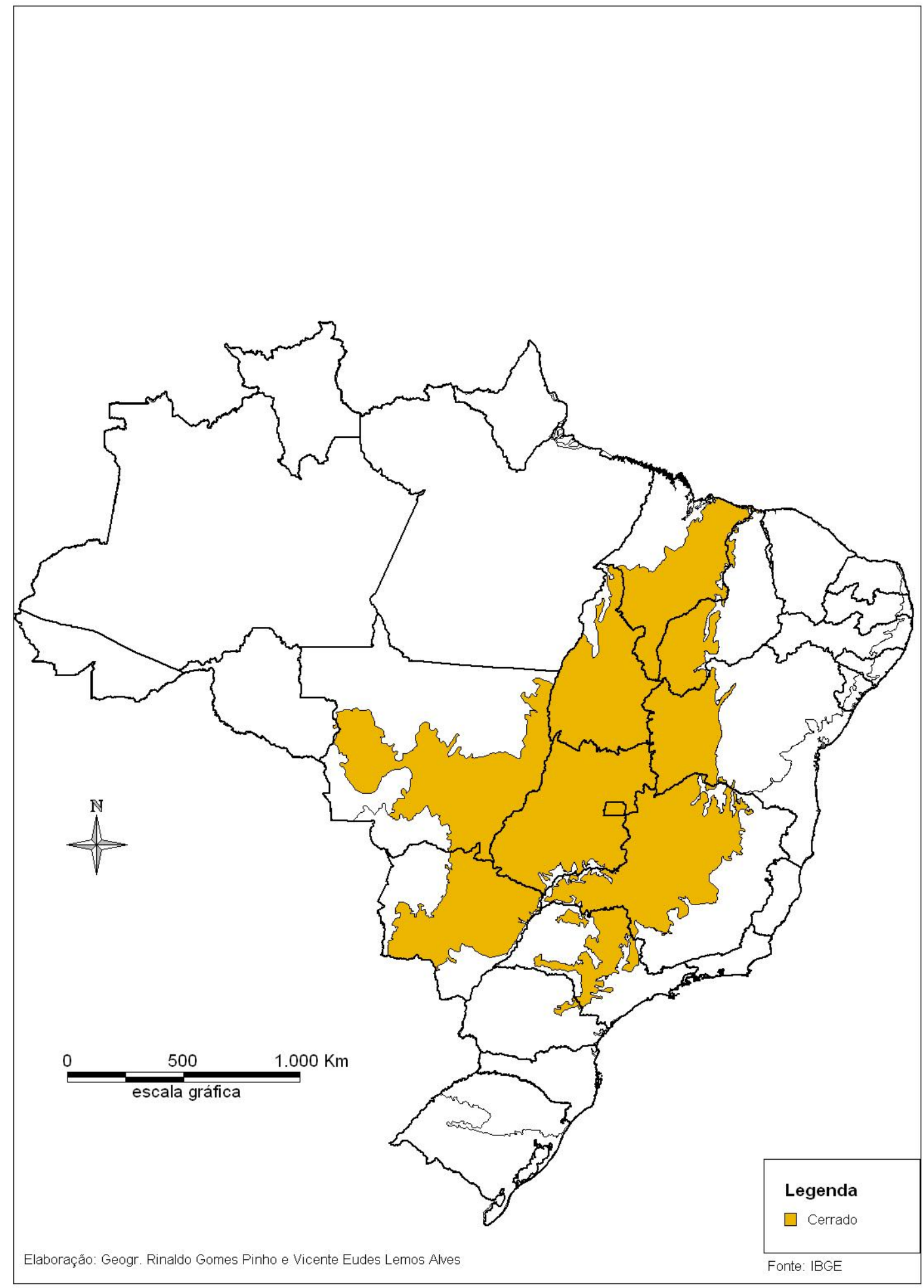


As terras das chapadas, que também podem ser denominados de "gerais", ao contrário dos vales úmidos, despertavam poucos interesses de ocupação privada por parte da população dos cerrados até recentemente. Constituíam, dessa maneira, lugares não cercados. Desde a fase inicial de modernização brasileira, essas terras se caracterizavam pelos amplos descampados de quase nenhuma presença humana, mas com abundância de recursos naturais aproveitados para o pastoreio do gado e para suprirem as necessidades dos moradores dos sertões. Distantes dos principais centros econômicos da colônia, esses moradores viviam carentes de outros gêneros de alimentação a não ser os obtidos pelo que a natureza oferece e pelo que se planta e se cria. Os gerais foram aproveitados, nesse sentido, para tudo aquilo que se torna escasso nos vales úmidos: caça, madeira, lenha, mel, plantas medicinais, frutas etc. Esse uso é facilitado, ainda no período colonial, pelo fato de serem terras não cercadas, apesar de sua constituição privada, pois eram terras concedidas através de sesmarias. O uso livre ou comunitário dos gerais, entretanto, será difundido pela impossibilidade do sesmeiro usar minimamente a concessão fundiária real devido às suas grandes dimensões, mas também porque se consolida um direito consuetudinário imposto pela metrópole à colônia, cujos termos estabelecem espaços de uso público entre as sesmarias. Prado Jr. (1965: 187) nos esclarece sobre a expansão das fazendas de gado nos sertões do Brasil:

"Uma fazenda de gado se constitui em geral com três léguas de terra, dispostas ao longo de um curso d'água, por uma de largura, sendo meia para cada margem. Este tipo padrão de fazenda deriva da limitação estabelecida na Ordem Régia de 27 de dezembro de 1695, confirmada em disposições posteriores, e que fixou a área das sesmarias a serem concedidas. E o tipo prevalecia. Entre cada sesmaria ou fazenda medeava ainda uma légua de terras que se conservavam devolutas; nesta légua nenhum dos confinantes podia levantar construções ou realizar quaisquer obras; ela serve apenas de divisa, providência necessária, onde não se usam cercas ou quaisquer outras tapagens, para evitar a incursão do gado em fazendas vizinhas e confusão dos rebanhos".

Esse direito se manterá sem muita alteração nas formas de uso, mesmo que pese sobre ele às sucessivas mudanças na legislação fundiária rural brasileira, como a Lei das Terras. Tais práticas somente passam, 
verdadeiramente, a serem ameaçadas com o advento da agricultura capitalista exportadora a partir de 1970. A possibilidade de torná-los celeiro agrícola importante conduzido por investimentos públicos, como a expansão dos créditos agrícolas, abertura de estradas, pesquisas em melhoramento dos solos e desenvolvimento de novas sementes adaptadas às condições do cerrado, além de sua topografia plana facilitando a mecanização, muda rapidamente a concepção que se tinha das terras dos cerrados e, em particular, dos gerais.

Alguns anos antes das primeiras lavouras de soja, a disputa pelos gerais se acelera, inicialmente menos pela possibilidade de obter renda a partir da propriedade dessas terras, mas mais porque adquirindo-nas por preços irrisórios ou por procedimentos ilegais representava o passaporte para o acesso a recursos financeiros dos vários programas de desenvolvimento regionais do governo federal. Os pretensos projetos de reflorestamentos ou de pecuária melhorada apresentados por empresas empreendedoras dos cerrados nos anos 1970 fazem parte dessa lógica. O comércio das terras dos platôs planos, com preços expandidos, para os agricultores modernizados foi o passo seguinte. Apesar de que, na década de 1940, Waibel (1979: 200) já havia identificado nos cerrados do Planalto Central a valorização dessas terras, indicativo de que a aquisição de parcelas delas ocorreu bem antes da expansão mais intensa de agricultores nos 1960 e 1970. Conforme nos relata em sua passagem pelos cerrados mineiros e goianos:

"Os preços das terras subiram extraordinariamente nos últimos anos; há dez ou quinze anos, um alqueire (4,8 hectares) de terras de mata de primeira valia 400 ou 500 cruzeiros; hoje em dia, os preços são dez vezes maiores, ou cerca de 4 ou 5 mil cruzeiros, no 'Mato Grosso' e no Triângulo Mineiro".

As primeiras lavouras nos cerrados, nos anos 1970, entretanto, não pertenciam à produção de soja, mas à de arroz. A soja se instala definitivamente nos cerrados dos estados do Centro-Oeste e Nordeste brasileiros apenas nos anos 1980, quando a sua consolidação já havia ocorrido nas regiões Sul e Sudeste do país, onde os primeiros sinais de seu arrefecimento apareciam. O tamanho crescente da área cultivada com essa commodity (gráfico 04) é indicativo da opção por esse bioma para a produção 
agrícola de exportação, tendo a soja como o carro-chefe. No gráfico que segue observa-se uma rápida expansão da área ocupada com soja, principalmente na região Centro-Oeste que supera as demais regiões destinadas à produção de soja.

Gráfico 4: Evolução da área ocupada com soja em anos selecionados - Brasil e Grandes Regiões (em mil hectares)

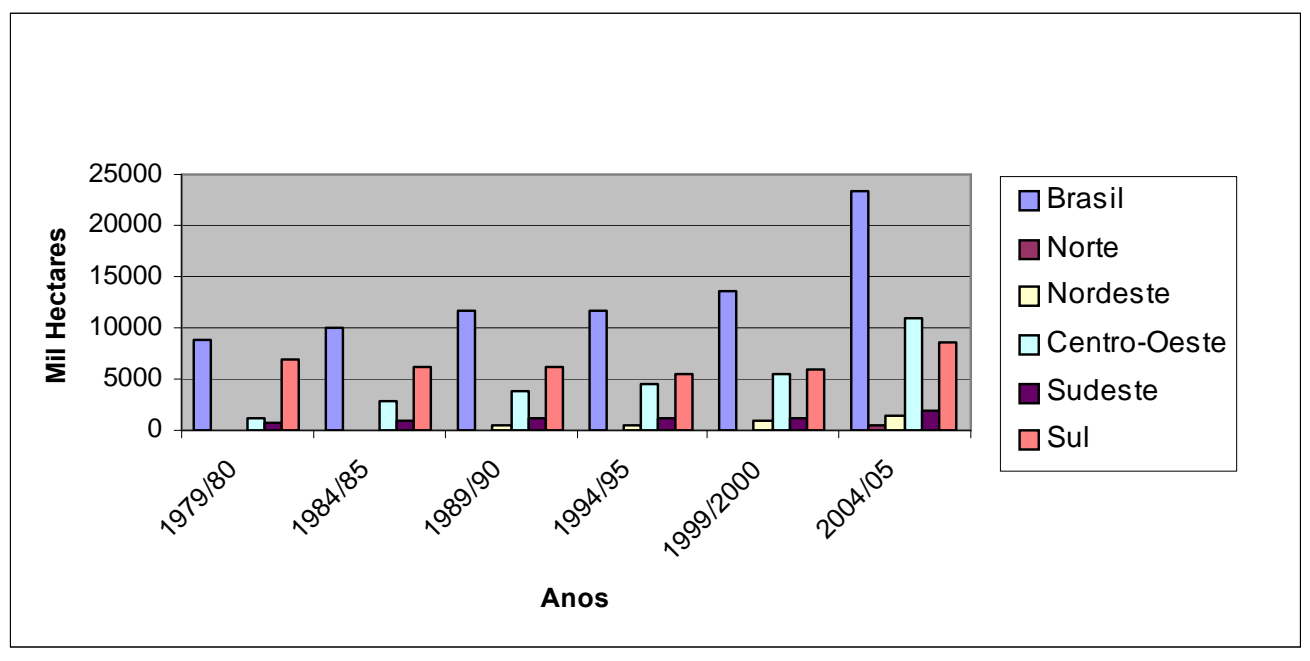

Fonte - Conab - Série Histórica de Área Plantada - Safras 1976/77 a 2005/06.

As disputas pela posse dos platôs se tornarão mais acirradas na medida em que os preços da soja crescem no mercado externo e as lavouras ocupam mais espaços desses domínios. O interesse por tais áreas cresce na mesma velocidade e passa a contar agora não somente com fazendeiros locais e camponeses, mas com a presença de outros agentes econômicos: agricultores individuais, empresas de colonização, de maquinários e de insumos, cooperativas agrícolas, e mais uma variedade de outros grupos não associados à agricultura, mas que apostam na propriedade fundiária nos cerrados como um meio de valorização de seu capital. A terra se torna, assim, nessas regiões um instrumento de renda para uma parcela dos representantes do agronegócio, através dela esses grupos asseguram a reprodução ampliada de seu capital, conforme, nos diz Martins (1997: 30):

"Aí, também, estamos em face de outra peculiaridade da situação da fronteira que é, ao mesmo tempo, definidora da mobilidade do desenvolvimento capitalista em nossa sociedade. Diversamente ou, ao menos, com muito maior intensidade do que aconteceu em outras sociedades capitalistas, entre nós o 
capital depende acentuadamente da mediação da renda da terra para assegurar sua reprodução ampliada. Por meio dela, recria mecanismos de acumulação primitiva, confisca terras e territórios, juntamente por esse meio atingindo violentamente as populações indígenas e, também, as populações camponesas. É que em grande parte essa reprodução depende da mobilização de meios violentos e especulativos para crescer em escala. Portanto, para que - capital possa reproduzir-se acima da taxa média de rentabilidade, com vantagens em relação a outros investimentos cuja localização geográfica lhes permita reter parcelas maiores da mais-valia realizada".

O movimento de valorização fundiária transformou vastas porções dos cerrados em propriedade privada. Essa área que se configurava, predominantemente pela presença de terras devolutas, passa a ser apropriada indevidamente pela ação de grileiros, os principais responsáveis pelo fortalecimento de um importante mercado imobiliário de terras agrícolas e urbanas nos espaços percorridos pela soja. São eles também os principais causadores dos inúmeros conflitos que se ampliam com magnitudes distintas de violência, principalmente contra os grupos locais, como os camponeses e indígenas. As formas de vida dessa parcela de moradores dos cerrados alteraram-se completamente nos últimos anos por conta do avanço das lavouras de grãos, principalmente nas áreas de uso comunitário, reduzindo as possibilidades de aproveitamento da diversidade natural existente anteriormente.

A remoção da cobertura vegetal dos gerais para colocar em seu lugar lavouras de soja desencadeou transformações na vida camponesa, não somente porque eliminou uma base importante de obtenção de recursos necessários à sua sobrevivência, mas porque o desmatamento afetou progressivamente as fontes de água dos vales reduzindo as nascentes ou assoreando os cursos d'água, anunciando uma crise ecológica.

Nesse sentido, o avanço do agronegócio nos cerrados ocorre alicerçado no processo de modernização excludente, na medida em que, por um lado, produziu aumento considerável das mercadorias agrícolas colocadas no mercado mundial em pouco tempo em função de novas estruturas de aceleração de produção e circulação, mas esse novo patamar econômico alcançado com a incorporação dos sistemas técnicos não subverteu as formas da modernização pré-existentes e ainda ampliou a exploração desmedida do trabalho e a degradação dos ambientes naturais. A modernização 
contemporânea ampliou a expropriação de parcelas significativas da população local, cuja expulsão de suas antigas áreas de moradias e de reprodução refletiu em aumento das crescentes e empobrecidas periferias das cidades do agronegócio.

\section{7 - A formação da logística de transporte nas áreas de expansão da agricultura moderna}

O avanço da agricultura capitalista em áreas de cerrados foi um marco importante para formação de um sistema de transporte interligando o interior aos outros centros econômicos do país. Apesar de suas feições continentais terem sido construídas ainda durante o período colonial, a integração do mercado nacional torna-se mais efetiva somente de meados do século $X X$ em diante, quando foram formuladas políticas mais eficazes destinadas à construção de infra-estrutura física (sistemas viários, de armazenamento, eletrificação, comunicação etc.) interligando regiões que até então pouco se comunicavam, a não ser no âmbito intra-regional ${ }^{14}$. Os arquipélagos territoriais (Oliveira, 1985) que constituíam conglomerados econômicos regionais, formados no Brasil colônia, permaneceram no império e ainda por longos anos na República. Se, por um lado, as condições materiais possibilitavam estabelecer maior fluidez entre os espaços da faixa litorânea brasileira, zonas de influência portuária, revelando a herança do passado colonial, por outro lado, não se efetivava com a mesma facilidade o contato do litoral com o interior. Somente com a industrialização brasileira e com a expansão da agricultura moderna em direção às novas terras, inseridas no processo de valorização do capital, é que esse cenário se altera.

As políticas públicas voltadas diretamente para a adequação desse espaço ao processo de aceleração da modernização tornam-se mais incisivas durante os governos militares, quando se mobilizou vultuosos recursos destinados à viabilização do escoamento das novas mercadorias agrícolas,

\footnotetext{
${ }^{14}$ Castillo (s/d) fazendo referência a L. Rodrigues (1947) argumenta que "a primeira integração do território brasileiro se consuma pela aviação e pela radiotelegrafia a partir dos anos 1930. Até esse momento, não havia um sistema rodoviário integrado que cobrisse todo o território nacional e as ferrovias, por sua vez, jamais ultrapassaram a escala da integração regional" ( $p$. 3).
} 
bem como de outras matérias-primas minerais e/ou vegetais produzidas nas regiões interioranas. O sistema logístico, de transporte e comunicação, ampliase nos anos posteriores, sobretudo nos 1990, através de grandes empreendimentos (inclusive com a participação de capital privado), visando aumentar a fluidez da circulação da produção, uma parte dela demandada pelo agronegócio, sustentado pela soja, que se consolida nas regiões de fronteira agrícola. A organização desse sistema responde em grande medida às pressões dos grandes grupos econômicos e sua execução segue a orientação dos interesses de lucratividade das empresas.

Para atender às novas demandas do agronegócio, representadas pelo crescimento da produção de commodities e pela presença de grandes empresas, instalam-se nas áreas de expansão da agricultura moderna no centro-norte do país importantes vias de circulação com o intuito de agilizar o escoamento das mercadorias. Além da malha rodoviária (que até os anos 1990 era responsável pela quase totalidade do transporte agrícola do país), outros modais de transportes são incorporados formando uma rede que passa a articular em condições mais favoráveis as novas áreas de produção de grãos aos terminais portuários de vários estados brasileiros. Os corredores de transporte que se formam na fronteira agrícola orientam suas rotas para as vias de saídas marítimas, indicando a quais agentes econômicos se pretende atender.

$\mathrm{Na}$ parte centro-noroeste do país para onde se expande a produção agrícola moderna dos estados do Mato Grosso, Rondônia, Amazonas e Pará (mapa 04), implanta-se um importante corredor de transporte multimodal que estabelece conexão com os portos hidroviários da Amazônia e os marítimos do Sul (Paranaguá-PR) e do Sudeste (Santos-SP). O sistema de escoamento que utiliza as saídas pela foz do rio Amazonas teve um substancial melhoramento nos últimos anos por conta de investimentos no transporte hidroviário.

O principal corredor que se forma nessa área aproveita a navegabilidade dos rios e os ramais rodoviários da região. Em um de seus eixos a produção de grãos segue pela hidrovia do rio Madeira a partir do porto de Porto Velho (mapa 04). A soja descarregada nesse porto é transportada por caminhões através da BR-364 e é proveniente de municípios do noroeste do Mato Grosso, do Amazonas e do sul de Rondônia. Da capital desse último estado partem 
barcaças pelo Madeira até o porto de Itacoatiara no rio Amazonas, onde ocorre o transbordo para navios marítimos com destino a países da América do Sul (sobretudo a Venezuela), da Europa e da Ásia. O porto fluvial de Itacoatiara é equipado com terminais graneleiros modernos sob a administração da empresa Hermasa Logística, do Grupo Maggi. No outro eixo do corredor, pode-se escoar soja e outros grãos do Mato Grosso pela BR-163 (Cuiabá-Santarém), através da qual a produção segue para o norte até os municípios paraenses de Itaituba ou Santarém (mapa 04). Nesse último, funciona desde 1974 o porto de Santarém, que possui condições de receber navios marítimos do tipo Panamax, com capacidade para transportar de 70 a 80 mil toneladas. Em 2003, a Cargill construiu no referido porto um terminal privativo possibilitando armazenar 60 mil toneladas de soja e onde se movimenta anualmente 800 mil toneladas do produto (Frederico, 2004). O uso da BR-163 como alternativa para o transporte da produção agrícola ainda não se consolidou totalmente, haja vista que na parte paraense dessa rodovia não existe pavimentação. Cogita-se, entretanto, para os próximos anos, seu capeamento asfáltico, o que deverá constituir um outro importante ramal de escoamento de grãos produzidos principalmente em Mato Grosso. A formação de um corredor centrado na BR-163, em torno do qual ocorreu à ocupação recente do norte do Mato Grosso, representou relevantes impactos para a região; sobretudo pelo fato de desencadear uma expansão urbana que possui uma forte lógica empresarial, produzindo, portanto, reflexos no desmatamento, na expulsão das comunidades camponesas e indígenas de suas terras e na apropriação irregular de terras públicas através da grilagem (Oliveira, 2005). 


\section{Mapa 04: Transporte de Soja da Região Norte de Mato Grosso - Ano 2000}

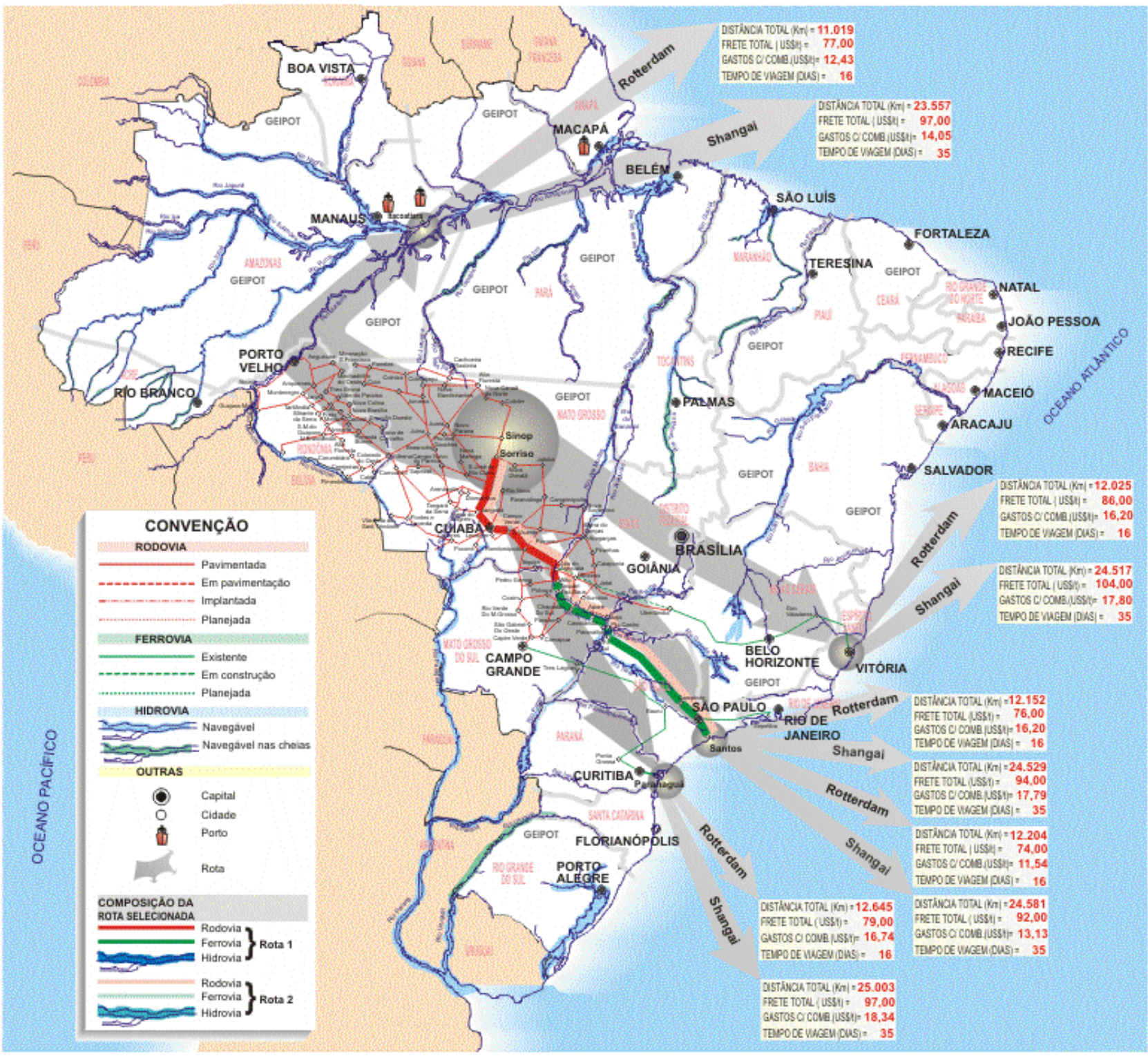

Fonte: Empresa Brasileira de Planejamento de Transportes - GEIPOT - Ministério dos Transportes - s/d 
A soja produzida nos cerrados centro-setentrional, sobretudo nos da Chapada dos Parecis-MT, também pode seguir para as regiões ao sul do país aproveitando as várias alternativas de rodovias e ferrovias que as interligam aos portos de Santos-SP, de Paranaguá-PR e de Vitória-ES. Atualmente esse é o trajeto mais adotado pelos produtores de grãos do estado do Mato Grosso, Mato Grosso do Sul e Goiás, embora seja o mais oneroso em função do longo trecho terrestre que se necessita percorrer (predominantemente por rodovias) até os portos de embarque mais ao sul. Essa rota torna também mais longa a viagem marítima, pois os principais centros consumidores se localizam no hemisfério norte. A outra opção de transporte da soja produzida no centro-norte matogrossense é a ferrovia Carajás seguindo até o porto de Itaqui (mapa 05).

$\mathrm{Na}$ área que abarca o centro-nordeste do território nacional, materializase um outro importante sistema de escoamento, composto por vários corredores de transporte envolvendo os três principais modais (rodoviário, hidroviário e ferroviário), os quais interligam a nova região produtora de grãos dos cerrados aos portos nordestinos. O "Corredor de Exportação Norte" é o principal eixo viário em atividade na região e por ele escoam, até o complexo portuário Itaqui/Ponta da Madeira-MA, os minérios extraídos da Serra do Carajás-PA e parte da produção agrícola de uma extensa região de agricultura moderna correspondente ao sul do Maranhão e do Piauí, oeste da Bahia, norte de Tocantins, nordeste do Mato Grosso e sudeste do Pará. Duas importantes ferrovias, a Estrada de Ferro Carajás (EFC) e a Ferrovia Norte-Sul (FNS), centralizam o escoamento realizado pelo Corredor. Elas são interconectadas por diversas rodovias através das quais circulam os caminhões em direção aos municípios troncos, áreas de transferência de modais. Os agricultores modernos dos cerrados maranhenses e piauienses utilizam intensamente esse corredor para o transporte da soja (mapa 06). A produção desses segue, predominantemente, pelas rodovias BR-230 e BR-010 até o parque intermodal no município de Porto Franco, onde ocorre o transbordo para locomotivas da ferrovia Norte-Sul, deslocando-se (após se conectar, em Açailândia-MA, aos trilhos da EFC) para o porto de Itaqui. Além da soja dos cerrados de Tocantins, que percorrendo pelas rodovias estaduais e pela BR-153, chega até EstreitoMA onde passa para vagões, o intuito é que os trilhos da Norte-Sul atinjam Goiânia-GO, formando um grande complexo viário de transporte de cargas 
interligando o norte e o sul do país. A extensão da referida ferrovia ainda é modesta frente aos 1.550 quilômetros projetados: a sua extensão atual, porém, é de aproximadamente 215 quilômetros entre Estreito e Açailândia. No primeiro semestre de 2006 foi concluído o trecho de 38 quilômetros entre Aguiarnópolis e Darcinópolis, em Tocantins. O seguinte trecho tocantinense (parte dele com obras iniciadas) de Darcinópolis a Babaçulândia $(58 \mathrm{~km})$ e desta a Araguaina (103 km) possui previsão de conclusão em dezembro de 2006 (Ministério dos Transportes, 2006). Projeta-se também prolongar a extensão dessa ferrovia interligando ao eixo central mais dois ramais. Um deles permitirá a conexão entre o município de Estreito e Balsas - MA, atendendo a principal região produtora de soja maranhense. O outro ligará Estreito a Xambioá-TO, possibilitando uma melhor integração com a hidrovia Araguaia-Tocantins. 


\section{Mapa 05: Transporte de Soja da Região Centro Leste do Mato Grosso - Ano 2000}

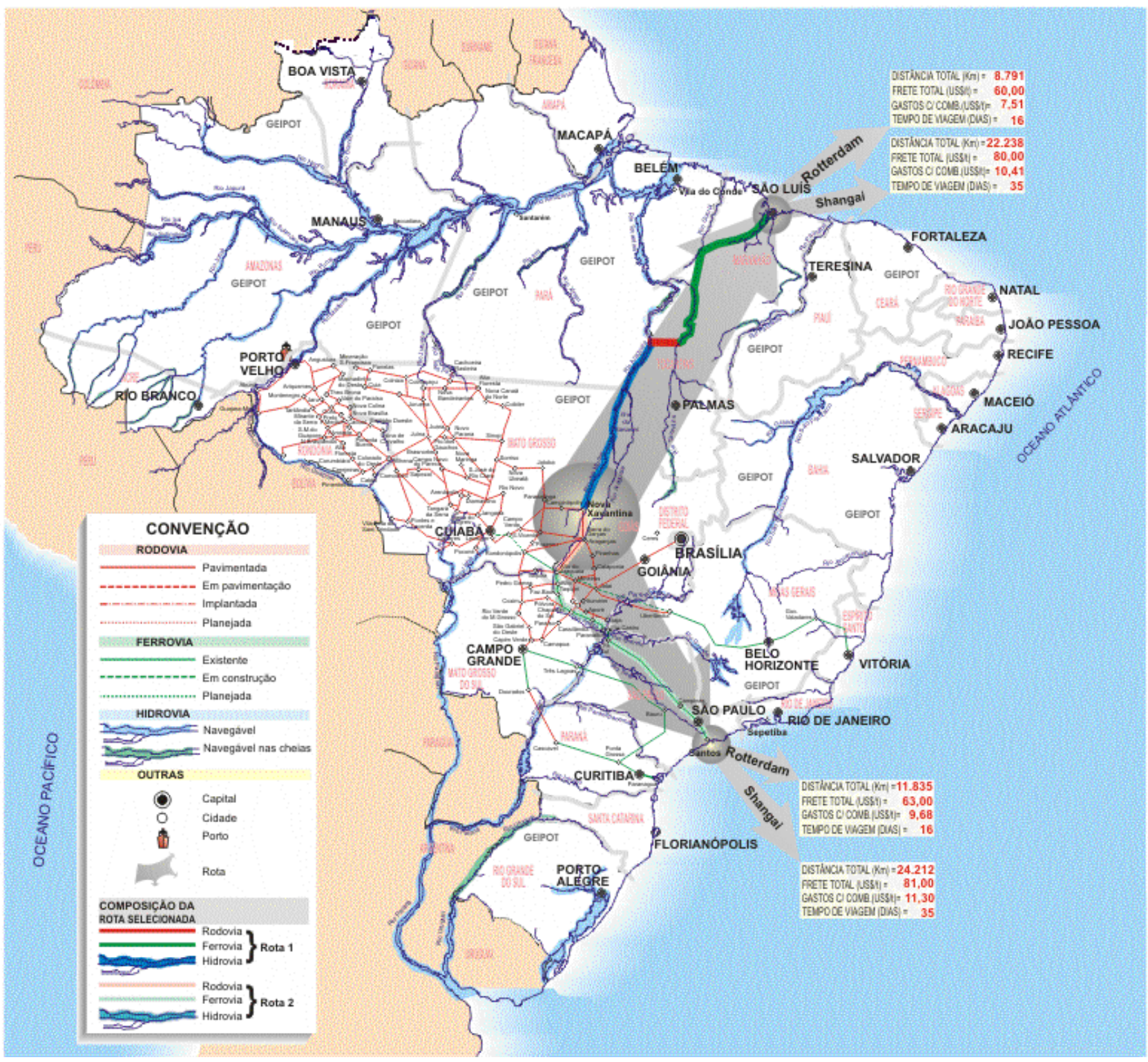

Fonte: Empresa Brasileira de Planejamento de Transportes - GEIPOT - Ministério dos Transportes - s/d 
Mapa 06: Transporte de Soja da Região Sul do Maranhão e Piauí - Ano 2000

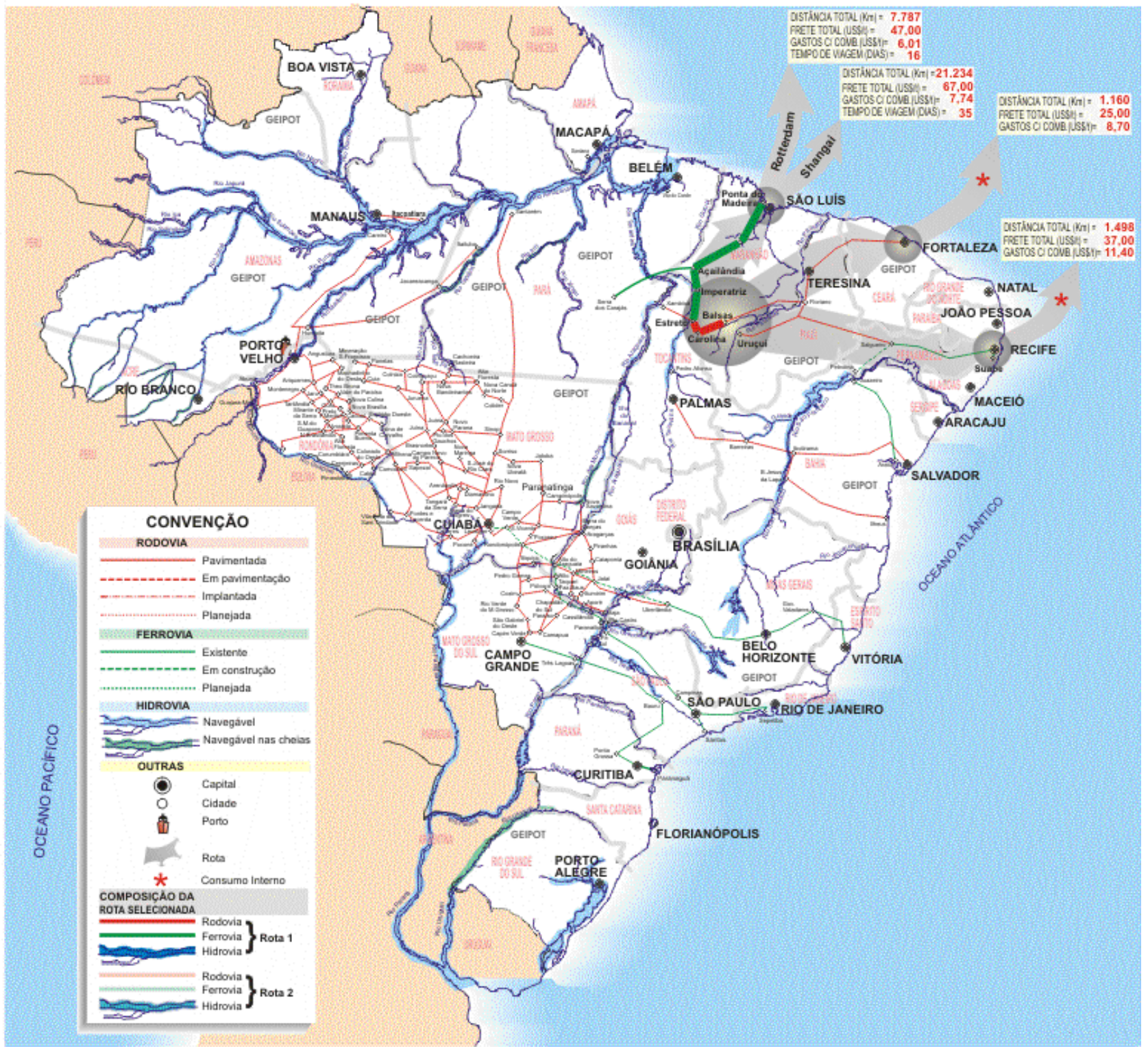

Fonte: Empresa Brasileira de Planejamento de Transportes - GEIPOT - Ministério dos Transportes - s/d 
A malha viária melhor estruturada que compõe o Corredor de Exportação Norte é, no entanto, a da Estrada de Ferro Carajás (EFC). Construída para transportar principalmente minérios, essa ferrovia passa nos anos 1990 a disponibilizar sua logística também para o escoamento de mercadorias agrícolas. No caso da soja, o volume transportado pela EFC passou de 280 mil, em 1997, para 490 mil toneladas, em 2000, sendo que, em 1992, foram escoadas por essa mesma ferrovia apenas 27 mil toneladas do produto. Esse crescimento do envio de soja pela EFC demonstra o interesse da Companhia Vale do Rio Doce (CVRD), concessionária da ferrovia, em também adequar suas estruturas de transporte para atender o setor agropecuário que avança na área do entorno da ferrovia, onde se forma uma extensa rede de interligação viária. A utilização do complexo portuário de Itaqui/Ponta da Madeira - o porto de maior profundidade do Brasil, suportando navios de até 420.000 TPB (Toneladas de Porte Bruto) - representa uma economia de tempo e recursos financeiros aos exportadores de mercadorias agrícolas, pois sua posição geográfica permite encurtar a distância, comparativamente a outros portos brasileiros, para importantes mercados consumidores, como os da Europa e os Estados Unidos.

O modal hidroviário (que deverá compor uma outra opção de transporte de grande escala na região, interligando suas rotas às de rodovias e de ferrovias do Corredor de Exportação Norte) ainda não se efetivou totalmente. Objetiva-se, entretanto, aproveitar a navegabilidade dos rios Araguaia, das Mortes e Tocantins para construir uma via de circulação de grãos produzidos nos estados do Mato Grosso, Pará, Tocantins e Goiás ${ }^{15}$. A proposta (para quando se concretizar o projeto de navegação Araguaia-Tocantins) é a de escoar grãos por essa hidrovia, seguindo num dos trajetos por todo o curso do rio Tocantins até a foz com o rio Amazonas, onde haverá, no Porto de Vila do Conde-PA, o transbordo das cargas para navios marítimos. No trajeto da hidrovia é possível aproveitar os pontos de entroncamento para transferência de modal, tais como os de interligação da hidrovia com as ferrovias Norte-Sul e

\footnotetext{
${ }^{15}$ As obras de execução da hidrovia Araguaia-Tocantins estão paralisadas por conta de processos judiciais movidos principalmente por entidades ambientalistas alegando que a navegação comercial nesses rios resultará em importantes impactos ao ambiente natural e às populações humanas que habitam seu entorno.
} 
Carajás. Inicialmente essa mudança de modal poderá ocorrer nos municípios de Estreito, Porto Franco, Imperatriz, no Maranhão, e Marabá, no Pará.

Outro corredor de escoamento nos cerrados nordestinos envolve dois importantes eixos de interligação aos portos exportadores do Nordeste. Tratase da hidrovia do Rio São Francisco e da ferrovia Transnordestina. Embora ainda em fase de formação, essas vias serão aproveitadas a partir de diversos modais, constituindo importantes rotas de circulação de mercadorias agrícolas e minerais, além de produtos manufaturados das indústrias que se instalam nas áreas de aceleração da modernização na região. O eixo do São Francisco ocorrerá com a efetivação plena da navegação comercial do rio (que atualmente trafega carga, em alguns trechos, de pequena escala) e terá papel de destaque na consolidação da logística de transporte entre o interior e o litoral abrangendo, sobretudo, os estados de Minas Gerais, Bahia e Pernambuco. A região dos cerrados do oeste baiano pode se beneficiar com a construção da hidrovia, na medida em que as opções de ligação aos portos marítimos serão ampliadas ao passo que os custos de transportes tendem a diminuir. A proposta é proporcionar futuramente a conexão do oeste baiano a um sistema intermodal rodo-hidro-ferroviário, no qual ocorrerão articulações rodoviárias desde Luiz Eduardo Magalhães/Barreiras, através da BR-242, até Ibotirama, onde acontecerá o transbordo para as embarcações que seguirão pelo São Francisco em direção a Juazeiro/Petrolina, passando, a partir de um terminal de cargas nessas cidades para os vagões da ferrovia Juazeiro-AratuIlhéus. Hoje, o transporte de grãos produzidos no oeste da Bahia segue predominantemente pelo modal rodoviário para os portos de Aratu e llhéus (mapa 07). É possível também transportar a produção dessa região baiana pelo Corredor de Exportação Norte, nesse caso o acesso a Estreito ocorre passando por Tocantins, através de rodovias estaduais (TO-070 e 060), até Palmas-TO de onde ruma para a BR-153 (Belém-Brasília) em direção à cidade maranhense onde ocorre a mudança da carga para os vagões da Ferrovia Norte-Sul. Esse percurso, no entanto, não é o mais utilizado para o escoamento da produção do oeste baiano, e sim o que se direciona para o litoral do próprio estado através das rodovias. 


\section{Mapa 07: Transporte de Soja da Região Oeste da Bahia - Ano 2000}

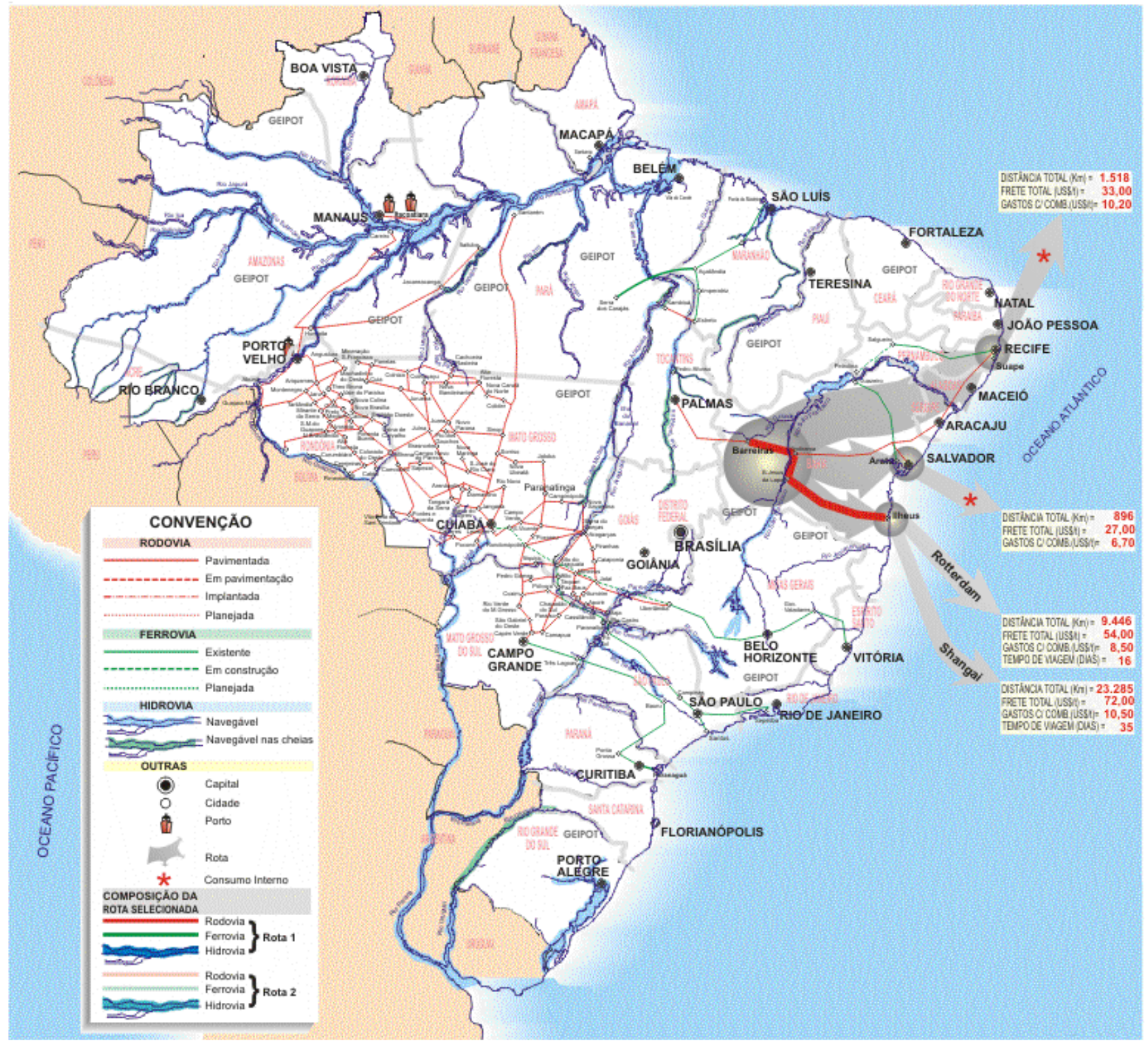

Fonte: Empresa Brasileira de Planejamento de Transportes - GEIPOT - Ministério dos Transportes - s/d 
A ferrovia Transnordestina forma o outro eixo e promete tornar-se uma via de ligação dos cerrados nordestinos aos portos marítimos de Suape, em Pernambuco, e Pecém, no Ceará. Projeta-se para 2009 o término dos 1.860 quilômetros de extensão da ferrovia a serem executados com aporte financeiro do governo federal e de empresas privadas. A participação desses dois agentes econômicos na execução de obras de tamanha envergadura deve-se ao modelo amparado pela nova legislação brasileira (Parceria Público-Privada - PPP), em que o Estado divide com a iniciativa privada parte da responsabilidade pelos investimentos em grandes obras de infra-estrutura no território nacional. A Transnordestina, um dos primeiros projetos em execução sob intervenção de tal modelo guiado pelos preceitos do neoliberalismo, iniciará seu percurso em Eliseu Martins, no sul do Piauí. Desse município situado na zona de contato do cerrado com a caatinga que se transforma em importante área de aceleração da produção agrícola moderna de grãos e de outros gêneros destinados à produção de biodiesel, como a mamona e, principalmente, a soja - a ferrovia seguirá em direção ao interior de Pernambuco até a cidade de Salgueiro, importante área de extração mineral, onde se bifurcará em dois ramais. Um deles ruma para o complexo portuário de Suape. O outro fará ligação ao porto de Pecém. No traçado projetado para a ferrovia existe ainda a formação de mais um ramal que chegará até JuazeiroBA/Petrolina-PE, onde será possível a transferência de modal a partir da hidrovia do rio São Francisco.

Observa-se, dessa maneira, que a organização da nova logística nas áreas de fronteira agrícola busca, sobretudo, atender às empresas vencedoras. Ela acontece somente após a instalação nessas áreas de grupos econômicos importantes do agronegócio que passam a pressionar o Estado por investimentos em sistemas de escoamento mais eficazes. Estes, por conseguinte, tornam-se especializados em transportar determinados produtos e cargas de grandes dimensões favorecendo o escoamento de mercadorias primárias aos pontos de saída para o mercado externo. O sentido da colonização aventado por Prado Jr. (1965), desse modo, que resultou no que o Brasil é hoje, numa sociedade basicamente fornecedora de mercadorias portando pouco ou nenhum valor agregado, continua presente na maneira pela qual o país se submete ao poder das grandes multinacionais, seja no que e em 
como produz seja na adequação do espaço para atender às demandas do mercado externo. Essas questões são percebidas mais detidamente nas escalas regionais do território, como pretendemos apontar nos próximos capítulos. 


\section{2 - A REPRODUÇÃO DO CAPITAL NOS CERRADOS NORDESTINOS}

\section{1 - Cerrados nordestinos: configuração de uma região do agronegócio}

Os cerrados nordestinos despontam recentemente como uma região de modernização agropecuária, evidenciando mudanças importantes na sua configuração sócio-espacial. De região de pouca expressão econômica sustentada na pecuária extensiva e na agricultura de subsistência transformase, a partir do final da década de 1970, em produtor de mercadorias agrícolas, destacadamente de grãos, processo que se amplia também para outras ramificações da cadeia produtiva do setor agroindustrial. As mudanças indicam que tanto as áreas rurais da região quanto as urbanas adquirem novos contornos espaciais, econômicos e demográficos, que resultam da presença de agricultores modernos, especialmente migrantes da região Sul do Brasil, e de empresas, algumas delas de grande porte, interessadas no lucrativo mercado do segmento do agronegócio.

O novo rural que se impõe nos cerrados nordestinos destaca-se pelo uso de meios técnicos modernos que auxiliam a produção agrícola contribuindo para o aumento nos patamares de produtividade, além de formar um sistema de infra-estrutura que proporciona maior rapidez no transporte das mercadorias até as fábricas de beneficiamento ou os portos exportadores. Esse movimento de modernização contemporânea conduz o rural dos cerrados nordestinos para novas configurações espaciais, substituindo suas antigas formas de produção por outras, sob o controle da agricultura capitalista.

O urbano, da mesma maneira, sofre relevantes alterações com o movimento de expansão da agropecuária moderna, na medida em que ele passa a cumprir novas funções e desenvolver novas dimensões econômicas, sobretudo no que se refere às formas de ampliação do consumo consuntivo e do consumo produtivo (Santos, 1993). A produção agrícola é quem impulsiona

a dinâmica econômica local, mas é nas cidades onde se instalam os suportes que permitirão as realizações do campo. Ocorre, nesse sentido, a transformação de um conjunto de cidades nos cerrados nordestinos, cujo papel passa a ser o de atender às novas demandas dos agricultores. Elas ganham centralidade diante do crescimento da agricultura produtivista. Trata-se das 
cidades de Barreiras e Luis Eduardo Magalhães - BA, Balsas - MA, e Uruçuí e Bom Jesus - Pl: esses núcleos urbanos se expandiram velozmente nos últimos anos e tornaram-se referências como lugares de acontecimento do agronegócio.

Pretende-se, assim, nesse capítulo, verificar de que maneira o crescimento da produção agrícola em bases modernas interfere na dinâmica regional e, em particular, como contribui para a construção de uma nova paisagem carregada dos elementos da técnica, mas que, paralelamente, traz consigo formas não homogêneas geradas pela destruição dos meios de vida da população local e pelo predomínio da monetarização nas relações sociais. Neste capítulo faremos, portanto, uma incursão pela região do que se costuma denominar de "cerrados nordestinos", com o interesse de tentar achar os nexos construídos pelo capital para dar forma a uma área que se reconfigura diante do avanço das forças produtivas associadas ao agronegócio.

\section{2 - Uma breve incursão pela região}

As características geográficas dos cerrados nordestinos indicam a ocorrência de particularidades espaciais em relação ao conjunto do Nordeste brasileiro, tanto no que diz respeito às formas fisiográficas quanto ao tipo de ocupação humana. No primeiro caso, predominam chapadões planos recobertos de vegetação de cerrado (foto 01), cuja extensão nos limites administrativos da região perpassa o oeste da Bahia, o sudoeste do Piauí e o sul e leste do Maranhão (mapa 08). Os cerrados nordestinos representam, entretanto, apenas um fragmento dessa unidade ecológica cujo prolongamento acompanha vastas áreas de todos os estados do Brasil Central e partes das terras de Minas Gerais e São Paulo (mapa 03). No que diz respeito à abrangência nordestina desse bioma, as primeiras formas de ocupação da região se caracterizaram pelo extrativismo vegetal, a agricultura camponesa e a pecuária extensiva, atividades que contribuíram para construir os contornos regionais modificados atualmente pela presença da agricultura moderna. 


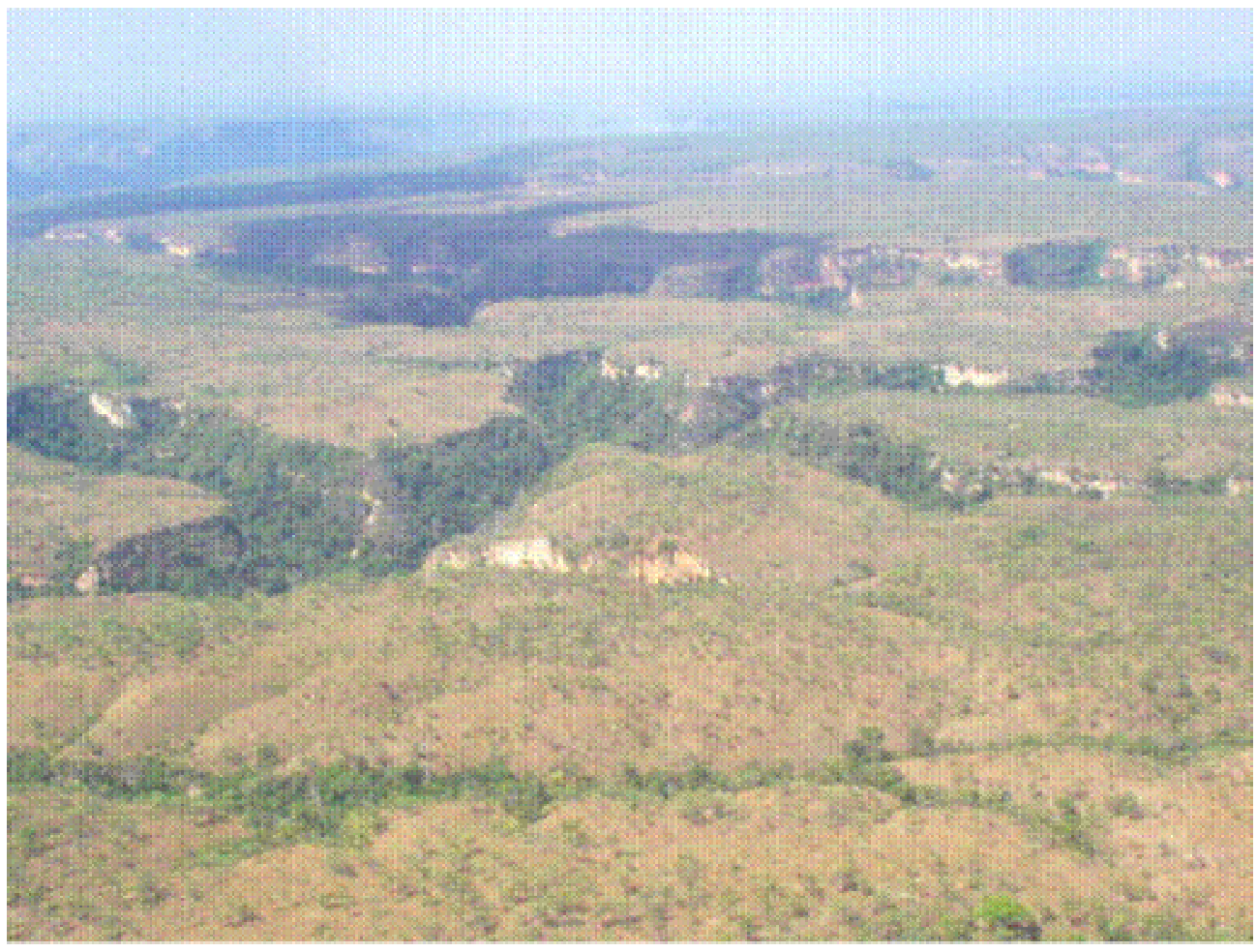

Foto 01 - Relevo $\theta$ vegetaça característicos dos platos planos dos cerfados nordestinos. Ibama, 2005. 
Mapa 08: Localização dos Cerrados Nordestinos

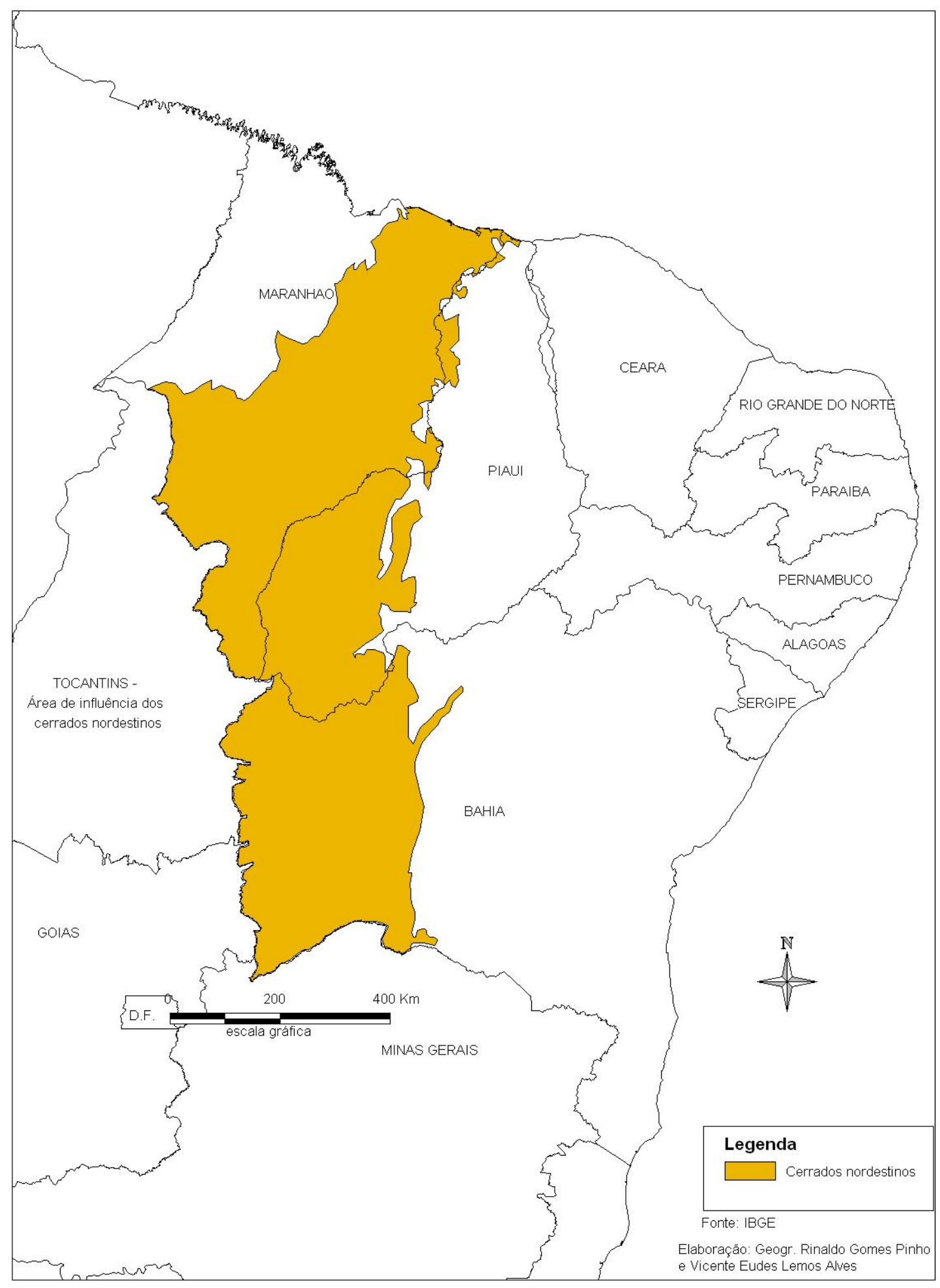


Segundo Diniz (1984:12), a porção ocidental do Nordeste expressa determinadas condições geográficas que possibilitam reconhecê-la como uma outra região no interior da diversidade sócio-ambiental nordestina. Tal autor reconhece uma unidade espacial abrangendo:

“(..) a porção mais centro-ocidental do Nordeste brasileiro, englobando 75 municípios do sul do Maranhão, sul do Piauí e oeste da Bahia. Abrange uma superfície de mais de 361 mil quilômetros quadrados, indo desde a depressão semiárida do São Francisco, a leste, onde as precipitações anuais não chegam a 800 milímetros, até as chapadas e chapadões do oeste, com precipitações anuais geralmente acima de 1200 mm, constituindo os Gerais".

Diniz aponta ainda uma outra especificidade no contexto geográfico daquela área, qual seja, um sistema de ocupação e uso do solo ligado: “(...) tradicionalmente à atividade pecuarista que lhe dá suporte econômico e explica seu povoamento". Sendo que, nesses domínios, aparecem quatro sistemas primários: "a) sistema da pecuária solta; b) sistema da roça; c) sistema de ocupação tradicional de várzeas e brejos; e d) sistema semi-extensivo tradicional de encostas e vales" (1984: 14).

Araújo (1995: 135) ao mencionar os cerrados nordestinos, associa essa base físico-geográfica aos acontecimentos econômicos manifestados nos últimos anos, cujo dinamismo resulta da expansão da atividade agroindustrial, sobretudo da soja. Ressalta a unidade regional pelo fato de corresponder a "áreas de moderna agricultura de grãos que se estendem dos cerrados do oeste baiano ao sul do Maranhão e Piauí".

Haesbaert (1996: 382) usa a expressão "novo nordeste" para caracterizar a região dos cerrados nordestinos, cuja:

“(...) ebulição econômica (e o aumento brutal das desigualdades sociais com as migrações do sertão impulsionadas pelo mito do 'eldorado' da soja) faz com que muitos denominem estas áreas de 'novo' Nordeste, e alguns políticos (inclusive com apoio de grupos sulistas) já começam a articular novos recortes políticoadministrativos capazes de corroborar essa nova divisão territorial do trabalho, ditada pela modernização seletiva da agricultura".

Consideramos, a rigor, que a região dos cerrados nordestinos abrange 0 oeste baiano e o sul dos estados do Maranhão e do Piauí, mas pode ser estendida como área de influência ao leste de Tocantins, que vive uma situação de modernização contemporânea semelhante e possui fortes vínculos econômicos com 
a parte nordestina dos cerrados, principalmente por que se tornou uma importante fornecedora de grãos de soja para as plantas esmagadoras da Bunge Alimentos de Luis Eduardo Magalhães - BA e Uruçuí - PI. Esses liames se estreitam, inclusive, pela emergência de disputas territoriais visando à posse de determinadas áreas de platôs planos que despontam para a produção de soja nas divisas dos estados de Tocantins, Bahia, Maranhão e Piauí. É nessas terras de domínios dos platôs recobertos pela vegetação de cerrados onde o movimento de aceleração da modernização contemporânea se impõe, caracterizando-se pela expansão da agricultura capitalista em bases tecnicamente modernas. Processo esse desencadeado a partir da década de 1970, mas que avança velozmente nos anos 1990.

A região em questão de recente expansão da agricultura capitalista apresenta uma configuração constando três $\operatorname{centros}^{31}$ de produção: oeste da Bahia (liderado por Barreiras e Luis Eduardo Magalhães), sul do Maranhão (liderado por Balsas) e sul do Piauí (liderado por Uruçuí e Bom Jesus). Apesar dessas áreas fazerem parte de um mesmo processo de imposição da modernização contemporânea e serem interdependentes, apresentam crescimento econômico não homogêneos. O oeste da Bahia, porém, é a área mais consolidada na manifestação do agronegócio.

Tal avanço da agricultura capitalista nos cerrados nordestinos transformou essas áreas em convergência de fluxos financeiros decorrentes da instalação de cooperativas, empresas de apoio à produção agrícola (revendedoras de insumos, implementos agrícolas, transportadoras, indústria de beneficiamento, de serviços especializados na agricultura etc.), além de agricultores capitalizados e de trabalhadores com ou sem qualificação em busca de empregos. Esses fatores impulsionaram a urbanização da região, sobretudo naquelas cidades onde ocorreu a intensificação da circulação de mercadorias tornando-se centro de realização da monetarização.

O fato de tal movimento apresentar situações distintas em função do avanço das novas forças produtivas confirma que a expansão do capital agropecuário na região ocorreu de forma não-simultânea, no que se refere tanto à localização das atividades econômicas, concentradas em poucas áreas criando espaços descompassos dentro do próprio conjunto regional, quanto à impossibilidade de

\footnotetext{
${ }^{31}$ Consideraremos para o estudo apenas os estados nordestinos com presença de cerrados.
} 
atender as demandas fundamentais da população local e dos que desembarcam na região com a esperança de acesso a uma ocupação, nem sempre concretizado.

\section{3 - Os cerrados baianos e suas novas dinâmicas: os casos de Barreiras e Luis Eduardo Magalhães}

Os cerrados do oeste da Bahia representam a principal área do Nordeste para a produção agrícola moderna de grãos, principalmente soja (mapa 09). Nessa subregião dos cerrados nordestinos encontram-se instaladas importantes empresas privadas processadoras de soja, como a Cargill e a Bunge Alimentos, além de cooperativas agrícolas e uma variedade de empresas de comércio e de prestação de serviços. A maior importância econômica nos cerrados nordestinos - pela presença de grandes empresas da cadeia da agroindústria, nos setores a montante e a jusante, e de comércio e serviços destinados à agricultura - coloca o oeste da Bahia como área de fluxo de produtores das outras sub-regiões, principalmente em busca de peças de maquinários e de serviços especializados. 
Mapa 09: Produção de Soja nos Cerrados Nordestinos, por Município - 2005

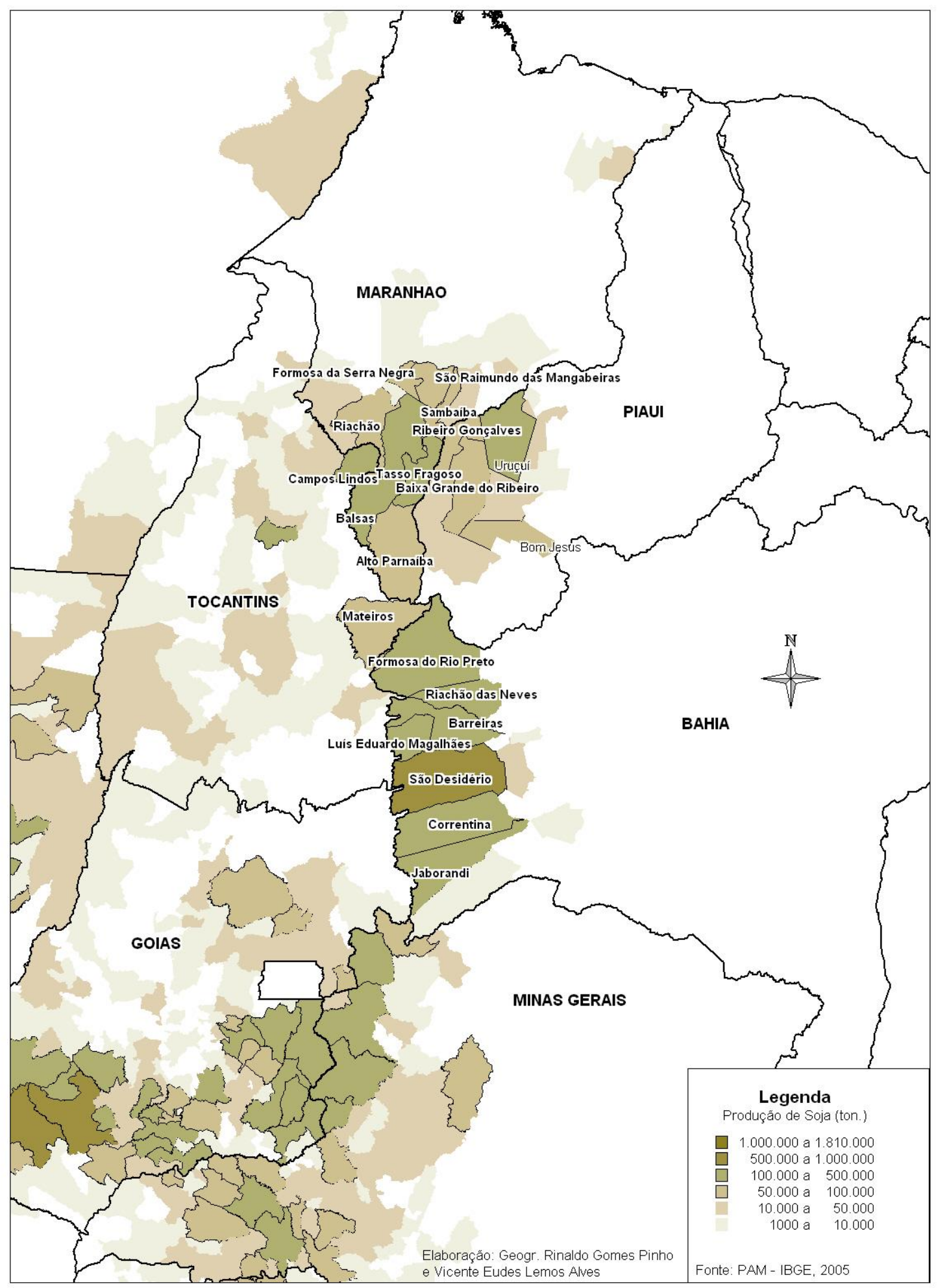


$\mathrm{Na}$ modernização agrícola contemporânea dos cerrados baianos, as ações econômicas estatais e privadas tiveram importante participação. A implantação de programas de desenvolvimento agropecuário contribuiu para que esse processo ganhasse amplitude. Ainda nos anos 1970, a Companhia de Desenvolvimento do Vale do São Francisco (CODEVASF) financiou projetos de colonização e irrigação em Barreiras e São Desidério (Superintendência de Estudos Econômicos e Sociais da Bahia/SEI, 2000). Destacam-se, também, os projetos e financiamentos agrícolas administrados pelo Programa de Desenvolvimento dos Cerrados (PRODECER), que teve atuação no oeste da Bahia em sua segunda etapa (PRODECER II); o apoio a pesquisas de melhoramento agrícola, através da Embrapa; os créditos financeiros facilitados, sobretudo em bancos públicos etc. Tais iniciativas colaboraram sobremaneira para o direcionamento do fluxo migratório para o oeste baiano, especialmente para Barreiras.

Aproveitando-se das ações governamentais e do baixo preço das terras, os sulistas lideraram a corrente migratória para os cerrados baianos e tornaram-se os principais responsáveis pela produção de grãos dessa área. Muitos desses produtores, acompanhados de seus familiares, venderam suas propriedades no Sul e resolveram tentar a sorte no oeste baiano investindo sua poupança em terras e maquinários. Os primeiros grupos chegaram na área no final da década de 1970, mas esse movimento se consolidou mesmo nos anos 1980. A presença desses migrantes com conhecimento de técnicas agrícolas modernas, com posse de grandes extensões de terras adquiridas e com possibilidade de obter financiamentos bancários facilitados permitiram o impulso das grandes lavouras, sobretudo de soja. Essa leguminosa passa em pouco tempo a deter a dianteira na produção agrícola do oeste baiano, atraindo capital não somente para a lavoura, mas também para seu beneficiamento, além de atrair comércio e serviços subsidiários.

Apesar da soja continuar liderando amplamente a produção agrícola dessa sub-região, percebe-se, em anos recentes, uma relevante expansão de outros produtos, como é o caso do café, do algodão, do sorgo e do milho (tabela 01). $\mathrm{O}$ algodão, que é plantado em sistema de rotação com a soja e o milho, vem se destacando no oeste baiano, ocupando atualmente a segunda extensão em área de produção e de movimento de capital, fato que desperta 
atenção de representantes do agronegócio, inclusive de empresas estrangeiras interessadas nesse lucrativo mercado. O cultivo dessa planta ocorre com o uso intensivo de mecanização agrícola e assessoramento técnico; além disso, crescem nos municípios dos cerrados baianos o número de usinas de beneficiamento e o de empresas compradoras do produto.

\begin{tabular}{|r|r|r|r|r|r|}
\hline \multicolumn{6}{|c|}{ Tabela 01 - Região oeste da Bahia - safra de grãos 2004/2005 } \\
\hline Cultura & Área (ha) & $\begin{array}{c}\text { Produção } \\
\text { (ton.) }\end{array}$ & $\begin{array}{c}\text { Produtividade } \\
\text { (kg/ha) }\end{array}$ & $\begin{array}{r}\text { Produtividade } \\
\text { (unidade) }\end{array}$ & $\begin{array}{r}\text { Valor bruto } \\
\text { Produção } \\
\text { (milhões } \\
\text { R } \$ \text { ) }\end{array}$ \\
\hline SOJA & 870.000 & 2.505 .600 & 2.880 & 48 sacas & $1.169,28$ \\
\hline ALGODÃO & 207.000 & 807.300 & 3.900 & 260 @car & 861,12 \\
\hline MILHO & 129.500 & 823.620 & 6.360 & 106 sacas & 205,91 \\
\hline CAPIM & 10.000 & 4.500 & 450 & 450 kg & 18,00 \\
\hline ARROZ & 30.000 & 68.400 & 2.280 & 38 sacas & 34,20 \\
\hline CAFÉ & 13.665 & 45.095 & 3.300 & 55 sacas & 263,05 \\
\hline PIPOCA & 6.000 & 18.000 & 3.000 & 50 sacas & 8,40 \\
\hline SORGO & 5.800 & 13.920 & 2.400 & 40 sacas & 2,55 \\
\hline MAMONA & 5.000 & 10.800 & 2.160 & 36 sacas & 6,84 \\
\hline FEIJÃO & 2.000 & 5.400 & 2.700 & 45 sacas & 6,30 \\
\hline OUTRAS & 210.000 & 650.000 & -------- & ----------- & 600,00 \\
\hline TOTAL & 1.448 .965 & 4.952 .635 & & & $3.175,65$ \\
\hline
\end{tabular}

Fonte: IBGE/AIBA - março/2005.

A pecuária bovina também ocupa uma extensão considerável dessas terras. Praticada de maneira extensiva até recentemente, e apesar de ainda ser feita desse modo em algumas das fazendas, sobretudo entre os antigos pecuaristas baianos, ocorreu um substantivo melhoramento do rebanho, o que torna a bovinocultura, juntamente com a avicultura e a suinocultura, um importante elo da cadeia de produção de alimentos sob o comando das grandes empresas.

O oeste da Bahia congrega, comparativamente aos outros centros dos cerrados nordestinos, uma melhor infra-estrutura viária, ocorrendo ligações com os principais mercados do país e os portos exportadores. A localização 
geográfica dessa área permite acesso facilitado a dois importantes corredores de exportação: aquele que se direciona aos portos de Aratu e llhéus com conexão aos portos de Tubarão (ES) e Suape (PE); e aquele que se comunica com o Corredor de Exportação Norte, a partir da conexão com o sul do Maranhão, atingindo o porto de Itaqui.

O melhoramento das condições de produção e a integração da área aos grandes mercados consumidores, externo e interno, produziram uma elevação do preço da terra com grande velocidade. A título de exemplo, para um hectare de terra nessa área que poderia ser comprado, no final da década de 1980 , por até $R \$ 25,00$, atualmente é preciso desembolsar de $R \$ 1.000,00$ a $R \$ 2.000,00$ no caso de terra bruta, e de $R \$ 2.000,00$ a $R \$ 3.500,00$ no caso de terra cultivada ${ }^{41}$. A rápida elevação no preço da terra indica que a especulação fundiária tornou-se um elemento importante no processo de ocupação do oeste baiano recentemente, produzindo uma outra camada de grandes proprietários de terra, representada agora por agricultores modernos.

\subsection{1 - Barreiras: ascensão e perda da centralidade do agronegócio nos cerrados nordestinos}

O município de Barreiras no contexto do oeste baiano é o de maior população e o principal concentrador de indústrias, de comércio e de serviços, assumindo o papel de área mais monetarizada dos cerrados nordestinos. Embora se trate de um núcleo antigo, surgido ainda no período colonial e marcado pela mineração, Barreiras foi elevada à categoria de município somente no final de século XIX (Velasco, 2004). Antes mesmo da década de 1970, o município já se destacava no Nordeste ocidental, na medida em que era a principal área de entreposto comercial, especialmente de produtos da pecuária. O município ganha impulsão na sua economia na década de 1960, após a fundação de Brasília, quando se tornou local de passagem de migrantes em direção à nova capital federal e lugar de entroncamento de rodovias ligando as regiões Norte, Centro-Oeste e a outras localidades do Nordeste. Até o início da década de 1980, todavia, a importância econômica

\footnotetext{
${ }^{41}$ Jornal Folha de S.Paulo, Dinheiro (04/05/2004).
} 
de Barreiras não expressava uma abrangência para além da própria subregião; os 41.454 habitantes (Censo do IBGE, 1980) não representavam mais do que $12,31 \%$ da população do oeste da Bahia.

Nas décadas de 1980 e 1990, entretanto, o município adquire uma nova dinâmica expandindo e diversificando suas atividades econômicas sob a liderança, a partir de então, das empresas do agronegócio. Houve uma acumulação progressiva da atividade comercial, sobretudo a de varejo, que passa de 216 estabelecimentos, em 1980, para 3.342, em 2000. No mesmo ritmo cresceram as atividades prestadoras de serviços, de 62 estabelecimentos, em 1980, para 1.520, em 2000. Ocorreu também um incremento da indústria de transformação no município, passando, no período indicado acima, respectivamente, de 17 para 406 estabelecimentos ${ }^{42}$. Esse avanço das atividades foi acompanhado por um fluxo migratório de população com destino ao município, que teve uma taxa média de crescimento populacional anual de 7,58\% (no período intercensitário de 1980 e 1991), de 4,18\% (entre 1991 e 1996) (SEI, 2000) e de 3,20\% (entre 1996 e 2000, segundo o IBGE). Ou seja, a população que era de 92.462 habitantes, em 1991, passa para 113.695, em 1996, e para 131.849, em 2000. A incorporação de população revela, ainda, que esse fluxo direcionou-se, principalmente para a área urbana do município, haja vista a sua expansão urbana ocorrer num ritmo muito mais acelerado do que a área rural. $A$ população urbana de Barreiras que era de 30.055 habitantes, em 1980, passa para 70.870 habitantes, em 1991; 87.455, em 1996; e 115.784, em 2000 (tabela 02).

\footnotetext{
${ }^{42}$ Dados levantados pela JUCEB, em novembro de 2003, in: Velasco, 2004.
} 


\begin{tabular}{|c|c|c|c|c|}
\hline \multicolumn{5}{|c|}{$\begin{array}{l}\text { Tabela } 02 \text { - População total residente no municipio de Barreiras - BA por } \\
\text { situação de domícilio }\end{array}$} \\
\hline \multicolumn{5}{|c|}{ Município = Barreiras - BA } \\
\hline \multicolumn{5}{|c|}{ Variável = População residente (Habitante) } \\
\hline \multicolumn{5}{|c|}{ Sexo $=$ Total } \\
\hline \multirow{2}{*}{ Situação do domicílio } & \multicolumn{4}{|c|}{ Ano } \\
\hline & 1980 & 1991 & 1996 & 2000 \\
\hline Total & 41.454 & 92.640 & 113.695 & 131.849 \\
\hline Urbana & 30.055 & 70.870 & 87.455 & 115.784 \\
\hline Rural & 11.399 & 21.770 & 26.240 & 16.065 \\
\hline
\end{tabular}

Fonte: Censo Demográfico, IBGE, 2000.

Apesar da expansão rápida da urbanização, houve também um saldo positivo da população rural de Barreiras entre os anos de 1980 e 1991, ocorrendo um arrefecimento do crescimento nesse setor somente em anos mais recentes, o que contrasta com a maioria dos municípios da região cujo saldo de população rural foi negativo desde a década de 1980 (SEI, 2000). Em Barreiras a população rural cresceu, em média, 6,05\% ao ano, entre 1980 e 1991, e 3,81\%, entre 1991 e 1996. O campo de Barreiras que abrigava 11.399 habitantes, em 1980, passa para 21.770, em 1991, e 26.240, em 1996. Somente no período intercensitário de 1996 e 2000 há um acentuado decréscimo da população rural do município, passando para 16.065 habitantes, ou seja, uma média de redução anual de 7,76\%.

As causas da urbanização acelerada de Barreiras estão associadas à expulsão da população rural do próprio município ou principalmente das áreas vizinhas decorrente da expansão da agricultura moderna que ocupou terras de posseiros e pequenos proprietários. Esse avanço da agricultura de grãos além de aumentar a mecanização, desocupando trabalhadores, implicou numa maior concentração fundiária dessa área (SEI, 2000), fatores que tiveram reflexos sobre a urbanização de Barreiras. Acrescenta-se também o fato de muitos dos migrantes sulistas escolherem a cidade de Barreiras para fixar residência.

A expansão da população rural nos períodos analisados de 1980 a 1996, com decréscimos nos anos posteriores, explica-se porque uma outra 
parte das famílias de migrantes, sobretudo os sulistas, foi residir nas próprias propriedades adquiridas. Esses novos moradores formaram pequenos povoados com características inicialmente agrícolas, núcleos que freqüentemente eram mantidos por uma cooperativa. Surgem daí (a partir da aglomeração de produtores e trabalhadores rurais, de empregados das cooperativas e de empresas agrícolas recém-instaladas) vários novos povoados nessa área. Destacam-se nesse caso: Mimoso do Oeste, Novo Paraná e Bela Vista (em Barreiras); Roda Velha de Cima e Roda Velha de Baixo (em São Desidério); Placas, Águas Claras e Rosário (em Correntina) (SEl, 2000).

Muitos deles tornaram-se áreas urbanas, como é o caso de Mimoso do Oeste, transformado em distrito do município de Barreiras em 1997. A população do então povoado, em 1996, era de 4.600 habitantes (SEI, 2000), aumentando para aproximadamente 20.000 habitantes segundo levantamentos do último Censo Demográfico do IBGE, de 2000. Essa população, provavelmente, foi incluída na primeira situação como rural e na segunda como urbana, visto que Mimoso do Oeste teve um rápido adensamento urbano na segunda metade dos anos 1990 e já apresentava todas as características e infra-estrutura de uma cidade. Outra explicação para a acelerada perda de população rural do município de Barreiras, entre 1996 e 2000, diz respeito ao avanço do agronegócio na região nos últimos dez anos, agravando ainda mais a situação dos camponeses, seja porque perderam suas terras para os grandes produtores/especuladores, seja porque tornou-se quase inviável produzir em pequena escala diante do cerco da grande produção agrícola monocultora ou da pecuária melhorada nessa região. Agrava-se, ainda, pelo aumento da degradação dos ambientes naturais, verificado em anos recentes, tais como o desmatamento, o assoreamento dos rios, o desaparecimento das nascentes dos principais rios e da fauna da região etc. Ou seja, a extinção dos meios de vida da população camponesa produz como conseqüência o abandono de suas unidades produtivas, tendo como uma alternativa encaminhar para as cidades; a cidade de Barreiras recebeu parte dessa população.

A consolidação da liderança regional de Barreiras, nos anos 1980 e 1990, como principal área do oeste baiano do agronegócio, abranda-se nos 
primeiros anos do novo século; o ritmo de crescimento das atividades econômicas do município não apresenta a mesma intensidade (gráfico 05). Isso se explica pelo fato da perda, em 2000, de parte de seus domínios para a constituição do município de Luis Eduardo Magalhães na antiga área do povoado Mimoso do Oeste. O recém-formado município ficou não somente com uma parcela da produção agrícola local, mas com importantes empresas do agronegócio, transferindo o eixo econômico da região de Barreiras para Luis Eduardo Magalhães.

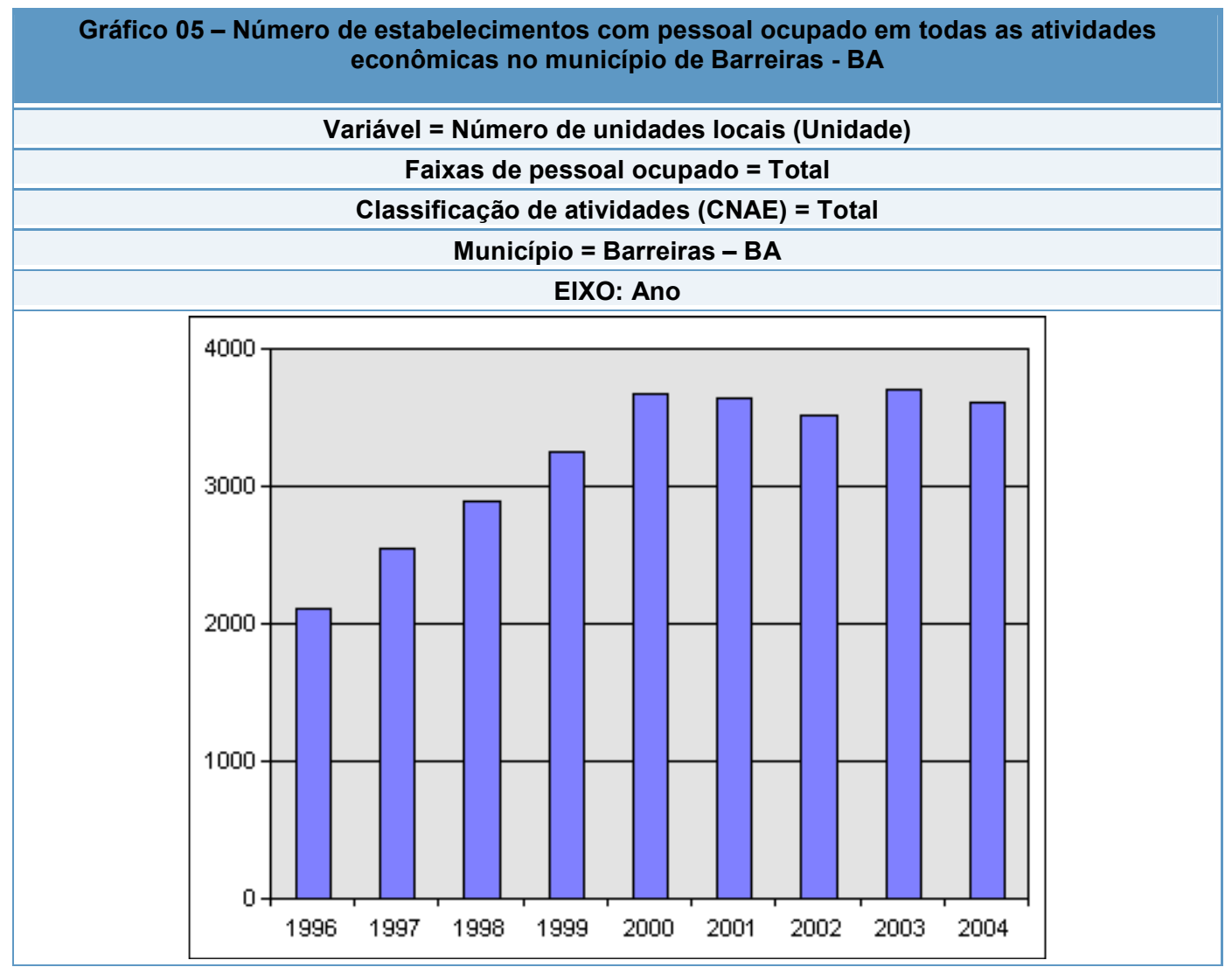

Fonte: IBGE - Cadastro Central de Empresas, 1996-2004

Percebe-se, nesse sentido, que a concorrência entre os lugares também se coloca para outros níveis de relações seja de pessoas, de empresas ou mesmo de mercadorias, confirmando o papel da universalidade do mercado como mediador das relações. As decisões, portanto, de produção de mercadorias não competem mais aos lugares seguindo a orientação de suas necessidades, nem mesmo às economias nacionais, mas aos grandes 
mercados consumidores. A agricultura do oeste baiano confirma essa premissa, na medida em que ela se ajusta a todo instante às leis totalitárias do mercado. Em Barreiras, assim como nos demais municípios dessa sub-região dos cerrados, a soja não representa atualmente a mercadoria de maior dinamismo na produção agrícola local, sofre a concorrência do algodão, transformado no principal produto agrícola de interesse das grandes empresas. A expansão do algodão nos cerrados baianos afeta mais diretamente, entretanto, as culturas voltadas prioritariamente para mercado interno, como o feijão (tabela 03).

\begin{tabular}{|c|r|r|r|r|}
\hline \multicolumn{2}{|l|}{ Tabela 03 - Produção de algodão e feijão no município de Barreiras - BA } \\
\hline \multirow{2}{*}{ Anos } & \multicolumn{2}{|c|}{ Área colhida (ha) } & \multicolumn{2}{c|}{ Quantidade produzida (t) } \\
\cline { 2 - 5 } & $\begin{array}{c}\text { Algodão } \\
\text { herbáceo }\end{array}$ & Feijão em grão & $\begin{array}{c}\text { Algodão } \\
\text { herbáceo }\end{array}$ & Feijão em grão \\
\hline 1995 & 1.339 & 6.320 & 3.252 & 11.395 \\
\hline 1996 & 1.100 & 7.397 & 2.750 & 15.246 \\
\hline 1997 & 1.300 & 11.404 & 2.250 & 30.787 \\
\hline 1998 & 1.050 & 10.930 & 2.363 & 20.704 \\
\hline 1999 & 3.140 & 10.301 & 8.304 & 11.852 \\
\hline 2000 & 8.150 & 7.655 & 24.630 & 12.858 \\
\hline 2001 & 6.680 & 4.026 & 24.944 & 9.531 \\
\hline 2002 & 9.526 & 3.840 & 19.742 & 8.998 \\
\hline 2003 & 13.653 & 4.550 & 52.259 & 5.999 \\
\hline 2004 & 34.044 & 3.080 & 131.392 & 5.400 \\
\hline 2005 & 38.315 & 2.850 & 140.079 & \\
\hline
\end{tabular}

Fonte: IBGE - Pesquisa Agrícola Municipal, 1995-2005.

As mudanças verificadas nos números de produção agrícola acima corroboram a idéia de que a demanda do mercado externo ou do grande mercado consumidor interno tornou-se o fator determinante da dinâmica agrícola em Barreiras, assim como nos demais municípios da região. As oscilações na produção e na área ocupada dentre as culturas destinadas ao mercado alimentar interno (nesse caso, o feijão), com desempenho negativo, e as que atendem a setores da grande indústria têxtil (nesse caso, o algodão), 
com desempenho positivo, indicam que os lugares de produção são condicionados pelas decisões tomadas por agentes econômicos hegemônicos. As grandes empresas possuem, nesse sentido, um papel de destaque nessas decisões, pois elas comandam o processo de circulação dessas mercadorias; interessam a esses grupos, portanto, tomar posse daqueles produtos agrícolas que, em cada situação, possuem maiores potencialidades de inserção nos mercados globais. Acabam por comandar, portanto, o processo de produção desses produtos.

O urbano, do mesmo modo, acelera os processos de modernização se adaptando às novas contingências do mercado. A cidade de Barreiras é um exemplo da maneira pela qual a agricultura moderna influencia nas transformações do urbano. De reduzidas estruturas urbanas até os anos 1980, a cidade se fortalece a partir de então como o lugar dos principais fluxos de capital da região, potencializados pelo aumento da rede de comércio, de serviços e de algumas indústrias de transformação. Isso permitiu a expansão da urbanização, com o surgimento de inúmeros bairros que passam a abrigar trabalhadores expulsos do campo e migrantes atraídos pelas perspectivas do agronegócio. O urbano de Barreiras avança fragmentando seu espaço, com uma nítida segregação entre os pobres e os ricos: os que chegam para ocupar-se em trabalhos braçais nas lavouras, freqüentemente os nordestinos, e os que dirigem o processo de produção agrícola moderno, os sulistas. Estes últimos costumam habitar os setores mais valorizados da cidade e parecem empreender ali um outro tempo e outras formas de organização da vida que foge a qualquer determinação da cultura local; nessa parcela do urbano a organização predominante é a da cidade moderna, com infra-estrutura adequada aos anseios dos moradores endinheirados pelo sucesso do agronegócio. Destaca-se, nesse caso, o denominado "Bairro dos Gaúchos", localizado numa das extremidades da cidade e onde se encontram também alguns nordestinos com mais poder econômico. Nele, as casas são predominantemente de alto padrão em ruas asfaltadas, situação que contrasta com outras partes da mesma cidade.

No sentido inverso ao da cidade moderna que se ajusta aos novos tempos, impulsionados pelo poder das empresas, que direcionam as decisões 
sobre a configuração do novo urbano ${ }^{43}$, proliferam as periferias habitadas por um volume crescente dos cada vez mais pobres. São os sem-trabalho, mobilizados pelo trabalho e para o trabalho, mas que não conseguem se ocupar diante das impossibilidades do agronegócio de criar condições dignas para uma legião de desvalidos. Os que logram uma ocupação nas fazendas agrícolas modernas permanecem trabalhando apenas por pequenos períodos do ano, o restante do tempo sobrevivem de atividades informais na cidade e habitando os "aglomerados humanos de exclusão", conforme aponta Haesbaert (1997: 150):

"Uma cidade como Barreiras, que praticamente explodiu na última década, aumentando de maneira assustadora as desigualdades sociais, exibe de forma modelar os extremos a que pode chegar a desterritorialização no entrecruzamento confuso de múltiplos territórios e redes e nos aglomerados humanos de exclusão, com o surgimento de uma verdadeira cidade clandestina e excluída ou imersa em redes e territórios ilegais de sobrevivência".

Esse movimento de urbanização não homogêneo que cresce amparado na lógica da segregação sócio-espacial e pela especulação imobiliária ampliou os limites do urbano em várias direções afastando o antigo centro dos novos loteamentos, num contexto em que distâncias entre os locais de moradia e de trabalho se dilataram. Produz-se daí a necessidade de adaptar suas estruturas espaciais às novas formas de vida que, assim como nas metrópoles, estão associadas à presença do automóvel. Em Barreiras, nos últimos anos, cresceu substancialmente o uso de veículos automotores, sobretudo de modelos bastante requisitados nas áreas de agricultura moderna, como as camionetas, conforme se observa na tabela 04 . Tal fato indica que a cidade torna-se portadora de desigualdades de ritmos e formas, pois abandona suas antigas estruturas simples de relações de maior proximidade física e social entre os seus moradores para uma outra marcada

\footnotetext{
${ }^{43}$ Matos (1996:171) aponta que uma das características importantes do novo urbano que se consolida no espaço metropolitano (ao nosso ver, também podem ser estendida às cidades médias que se adaptaram ao processo de modernização agropecuário, guardadas, evidentemente, as devidas proporções entre as duas realidades urbanas), é a da "Persistência e consolidação de uma estrutura urbana polarizada e segregada, em que a estratificação social tem uma clara leitura territorial".
} 
por um sistema complexo de organização prevalecendo conteúdos regidos pelo dinheiro regulando e distanciando os indivíduos.

\begin{tabular}{|c|c|c|}
\hline \multicolumn{3}{|c|}{$\begin{array}{c}\text { Tabela 04 - Veículos cadastrados no município de Barreiras - BA, } \\
\text { segundo o tipo (1995 - 2003) }\end{array}$} \\
\hline \multirow{2}{*}{ Anos } & \multicolumn{2}{|c|}{ Tipo de veículo } \\
\hline & Automóvel (unidades) & Camioneta (unidades) \\
\hline 1995 & 44.265 & 11.768 \\
\hline 1996 & 44.469 & 11.833 \\
\hline 1997 & 55.379 & 22.116 \\
\hline 1998 & 66.071 & 22.364 \\
\hline 1999 & 66.746 & 22.581 \\
\hline 2000 & 77.375 & 22.913 \\
\hline 2001 & 77.760 & 33.089 \\
\hline 2002 & 88.052 & 33.183 \\
\hline 2003 & 88.524 & 33.311 \\
\hline
\end{tabular}

Fonte: Detran/SEI, 1995-2003.

A urbanização de Barreiras das duas últimas décadas revelou também uma área que se expande sob a insígnia dos especuladores da terra urbana. Ávidos por incrementar os seus lucros induziram a formação de loteamentos mesmo não portando as condições básicas para os transformar num lugar habitável. Além disso, impeliram o deslocamento da cidade em determinadas direções para viabilizar a valorização de áreas ainda não ocupadas. Cita-se como exemplo os loteamentos construídos nas proximidades dos eixos rodoviários formados pelas BR-242 e BR-020 e as estradas vicinais. O diagnóstico de Velasco (2004: 223) sobre a ocupação do solo urbano de Barreiras após a instalação do agronegócio confirma que a apropriação privada daquele espaço reverteu-se em novas modalidades de disparidades. Conforme aponta a autora: 
“(...) na cidade de Barreiras, historicamente, as ações implementadas não decorrem de uma política de desenvolvimento urbano. Não faltou solo urbano para atender o incremento populacional, contudo parece ter faltado a articulação de um projeto de cidade por cima dos interesses particulares, pontuais e conjunturais. Em síntese, Barreiras é o caso exemplar de pólo regional fortalecido em decorrência da modernização da organização produtiva no setor primário. Porém, esse crescimento econômico não foi acompanhado pela expansão e qualificação da infra-estrutura urbana e pela construção de instrumentos que orientassem essa expansão e contribuíssem para superar as mazelas e contradições inerentes, decorrentes das particularidades do processo de acumulação capitalista assentado nessa região".

No que diz respeito ao espaço agrícola, as formas não homogêneas impostas pelo processo de modernização contemporânea se assemelham às do urbano, ou seja, evidenciam-se dois conjuntos de áreas com formas e características distintas de reprodução: o da agricultura moderna e o da agricultura camponesa. O primeiro, de posse dos instrumentais de alta tecnologia avança sobre o da produção agrícola dos camponeses que ainda se valem de antigas estruturas agrárias para garantir os seus meios de vida, imprimindo nele um outro tempo, baseado no ritmo da natureza e com apoio de técnicas menos aperfeiçoadas. Esses grupos ainda permanecem instalados nos vales úmidos, no entanto, suas terras estão cada vez mais isoladas diante da investida dos agricultores capitalistas, que, na tentativa de homogeneização valem-se da coerção.

\subsection{2 - Luis Eduardo Magalhães (LEM) e a busca da homogeneização nos cerrados baianos através do fetiche da mercadoria}

O crescimento econômico dos cerrados baianos, sustentado no agronegócio, teve como conseqüência imediata o fortalecimento das cidades. O fluxo de empresas e de agricultores interessados em grandes extensões de terras a preços baixos desencadeou uma ocupação mais intensa naquela área, alterando os padrões de povoamento existentes até a década de 1980. Além de agravar a concentração da estrutura fundiária motivada também pela posse irregular de terras devolutas, esse movimento produziu uma rápida expansão da urbanização no oeste baiano. O processo contemporâneo de modernização conduziu, por um lado, a dilatação dos antigos centros urbanos 
da região, como é o caso de Barreiras, presenciando nos últimos anos o crescimento de sua população moradora na cidade. Por outro lado, a emancipação política de municípios da sub-região, antigos povoados que se desmembraram nos anos 1980 de suas antigas sedes, como Mansidão (1985), Wanderley (1985), Jaborandi (1985) e São Felix do Coribe (1989) (SEI, 2000).

O povoado de Mimoso do Oeste, transformado em município em 2000, se caracteriza pela diferenciação de outras aglomerações urbanas do oeste baiano, tanto nas formas de ocupação, subordinadas ao movimento do agronegócio, quanto nas características culturais e econômicas de seus habitantes, com predomínio de produtores sulistas. Esses fatores revelam os rumos adquiridos nessa sub-região a partir do avanço da agricultura capitalista. O início de Mimoso do Oeste ocorreu a partir da ocupação por migrantes - principalmente sulistas - dos gerais ao sul do município de Barreiras, de vastos chapadões que até o final da década de 1960 eram terras devolutas ocupadas por famílias de posseiros e por latifundiários baianos. Consta que o primeiro a chegar para comprar terras nesses domínios foi o alemão Hans Weprajetsky, que se apossou, em 1968, de uma área de 165 mil hectares. Posteriormente, em 1979, essas terras foram adquiridas pelo goiano Arnaldo Horácio Ferreira, dono de uma empresa de colonização que, além dessa área, incorporou outros milhares de hectares completando uma extensão de 172.800 hectares.

No entroncamento das rodovias BR-242 e BR-020, o migrante goiano construiu o posto de nome Mimoso em referência a uma antiga fazenda do lugar. Nas cercanias do posto se forma, no início dos anos 1980, o primeiro loteamento para abrigar os funcionários e os migrantes sulistas que desembarcam nos gerais baianos em busca de terras baratas. Muitos desses migrantes se transformam não somente em produtores agrícolas, mas também em comerciantes fundiários e de outros tipos de comércio e serviços no povoado, que se expandia velozmente pela instalação de novos migrantes. Além da comercialização de combustível, o proprietário do posto Mimoso adotou também uma outra estratégia para a ampliação de seus lucros, o comércio de terras para a agricultura e para a formação de novos loteamentos do ainda incipiente núcleo urbano que ganha formas ainda nos anos 1980 . 
Seguem esse mesmo caminho outros migrantes instalados em Mimoso do Oeste, tornando-se donos de imobiliárias. Tal fato indica que os primeiros moradores do então povoado, ao adquirir terras, vislumbravam, de posse delas, a possibilidade de aproveitá-las para a elevação de seu capital a partir da especulação imobiliária urbana, o que efetivamente aconteceu.

O posto Mimoso desempenhou uma importante função de aglutinar os novos moradores (foto 02). Além de local de abastecimento e de descanso de caminhoneiros, gerando um movimento intenso por conta da nova fronteira agrícola que crescia, no entorno do posto surgiam estabelecimentos comerciais de equipamentos e de serviços agrícolas, e as primeiras empresas, tal como a Cooperativa Agrícola de Cotia (CAC) que se instalou no local em 1985. Diante das novas oportunidades que se colocavam, muitos dos sulistas escolheram fixar naquela área suas moradias criando demandas para aberturas de novos loteamentos.

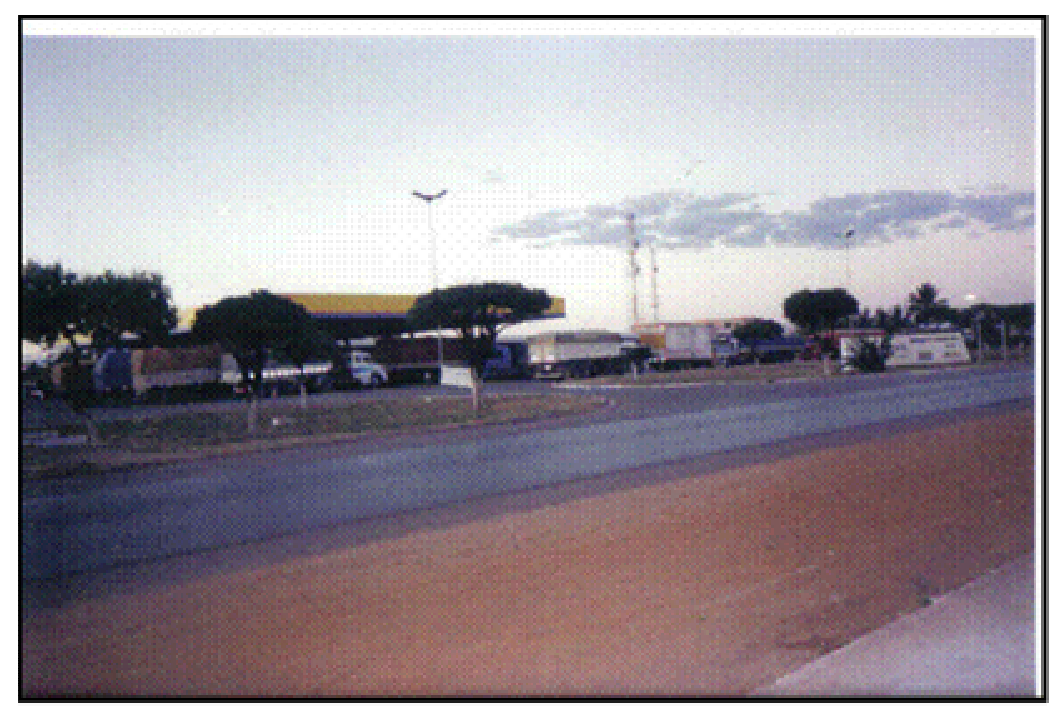

Foto 02 - Posto Mimoso - ao redor do qual iniciou-se o povoado de Mimoso do Oeste, atual cidade de Luis Eduardo Magalhães. Foto do autor, julho de 2005 .

O crescente interesse pelos cerrados baianos por pessoas de outras regiões e a expansão econômica permitiram à população do povoado de Mimoso do Oeste manter, desde o início de sua formação, o discurso de autonomia em relação a Barreiras, ampliando as manifestações em busca da emancipação. Esse movimento ganha volume também em decorrência de outros fatores, tais como: a estratégica localização do povoado no entroncamento para as cidades de Salvador, Brasília e Palmas (que o tornava 
mais atrativo do ponto de vista da lucratividade para grupos econômicos, já que existem mais possibilidades de relações econômicas com outros centros); a distância de cerca de cem quilômetros da cidade de Barreiras; a rápida expansão demográfica e econômica do povoado e o avivamento da rivalidade entre as populações das duas localidades cujas identidades étnico-culturais apresentam diferenças - as de Mimoso, de maioria sulista e as de Barreiras, predominantemente nordestina. Essa última questão tornou-se fundamental no processo de emancipação de Mimoso, na medida em que o discurso apontando a existência de uma identidade sulista contrapondo a baiana, inexistente no povoado, teve grande adesão de seus moradores. A disputa política pelo controle do território de Mimoso do Oeste, que se prolongou durante os anos 1980 e 1990, evidenciava uma notável oposição entre os dois grupos de identidades culturais distintas, como aponta Haesbaert (1997: 219222):

"Na escala municipal, considerando a imensa área da maioria dos municípios na região do oeste baiano, a luta pela emancipação de Mimoso do Oeste é o melhor exemplo de como o recorte identitário entre baianos e gaúchos permeia as relações sociais e os conflitos em curso na região, complexificando-se e fortalecendo-se através do espaço. [...] Entretanto, em certos níveis, a disputa com Barreiras, vista como uma 'cidade nordestina' e 'suja', desordenada, é muito nítida. Trata-se de uma disputa que vai além da nova divisão territorial do trabalho estabelecida com a chegada da modernização agrícola, desdobrando-se também numa espécie de divisão cultural do território que constrói, pelo menos ao nível das representações simbólicas, oposições que fornecem uma distinção clara entre sulistas e "nativos"'.

A criação do novo município somente se concretizou em março de 2000, rebatizado de Luis Eduardo Magalhães. A escolha do nome foi uma homenagem ao deputado federal morto em 1998, filho do então mais influente político da Bahia, o senador Antônio Carlos Magalhães. Resultou também de uma estratégia dos representantes do agronegócio, em sua maioria sulistas, para dirimir a resistência da oligarquia tradicional baiana, cujo principal representante é o próprio senador mencionado. A nova situação possibilitou ao recém criado município de Luis Eduardo Magalhães (LEM) controlar uma parcela considerável das terras agricultáveis da região, sendo que, em parte 
delas, havia a presença de projetos agropecuários modernos, sobretudo de produção de soja, algodão e café.

Atualmente, o grande dinamismo econômico que se reflete na área rural do município também se manifesta na área urbana, onde estão instaladas as mais importantes empresas da cadeia do complexo agroindustrial do oeste baiano, com destaque para a Bunge Alimentos e Fertlizantes, a Cargill, a Mauricéia Alimentos e a Galvani Fertilizantes. A presença dessas empresas, somada com outras demandas de produtores agrícolas e da própria população do município, gerou um crescimento substancial de novas atividades econômicas (gráfico 06), sobretudo de serviços, setor que mais se expande no município.

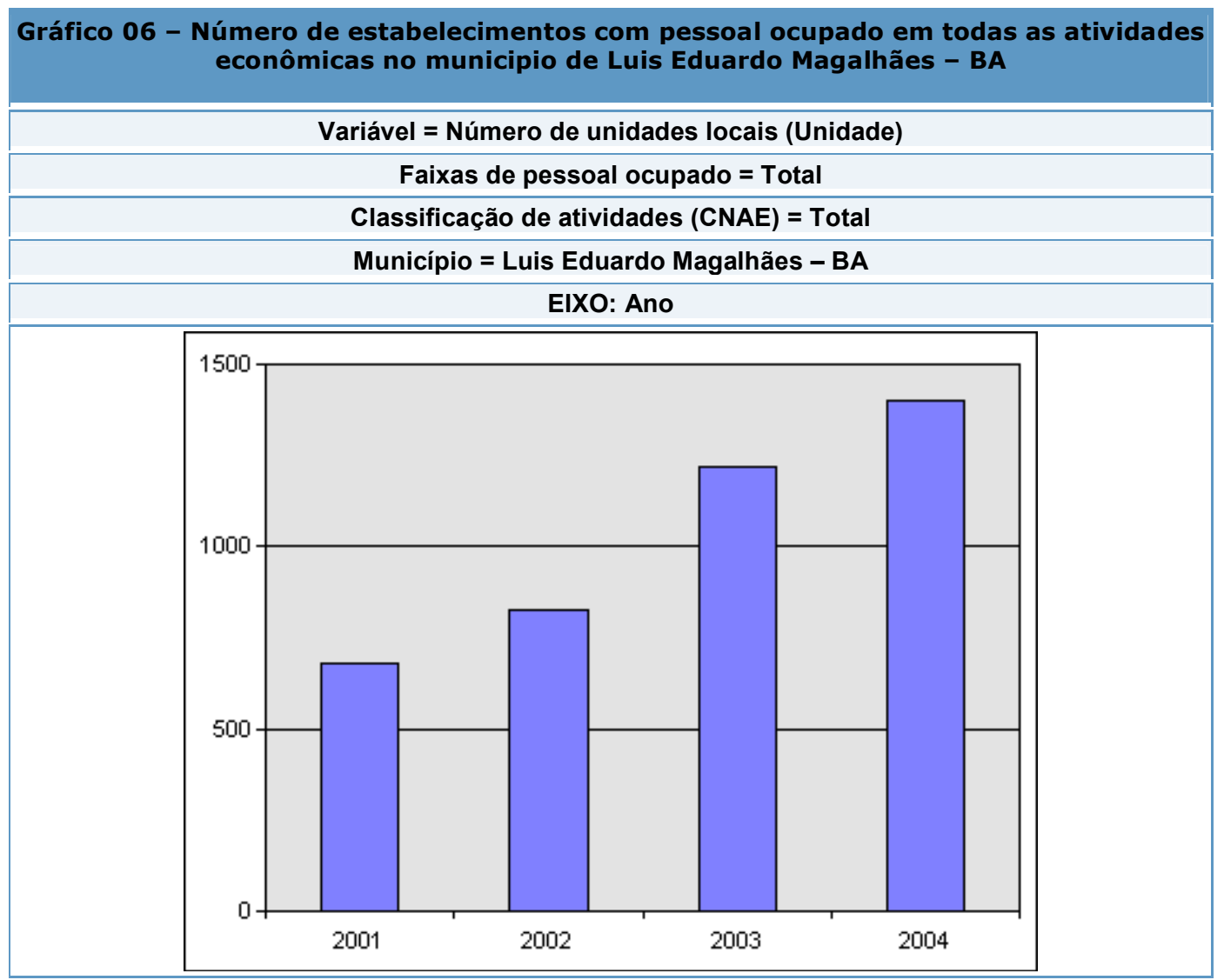

Fonte: IBGE - Cadastro Central de Empresas, 2001-2004.

O fluxo de atividades econômicas para Luis Eduardo Magalhães, especialmente após sua emancipação, provocou uma expressiva expansão urbana no novo município, originando grandes e rápidas transformações em 
seu espaço. A proliferação de loteamentos residenciais urbanos mostra uma cidade em construção. A maioria dos loteamentos encontra-se em formação, alguns apresentando somente terraplanagem, outros contêm casas dispersas em extensas e largas ruas traçadas em linha reta em forma de quadrado (foto 03). Tais loteamentos exibem uma padronização nas suas formas, apontando para novas manifestações de estilos de vida no oeste baiano. $O$ urbano de LEM implementa um novo padrão de arquitetura das residências, sem qualquer referência às formas difundidas pela cultura da região. Predominam os novos modos de vida urbanos difundidos pela sociedade moderna monetarizada, que dispensa a convivência com o vizinho ou com o espaço público. Em Luis Eduardo Magalhães a característica que destaca nos principais bairros é a ausência de pessoas circulando pelas ruas, nesses são valorizadas as habitações cercadas de muros quase instransponíveis, em que a comunicação com os vizinhos não é freqüente. As ruas do núcleo urbano estão mais adaptadas à circulação dos automóveis do que ao convívio social. Verifica-se, assim, em Luis Eduardo Magalhães a gestação de "um espaço fora do lugar" (Haesbaert, 1997), na medida em que se introduz naquela área uma outra concepção de funcionalidade do espaço urbano, que atende fundamentalmente às preocupações econômicas e culturais das empresas e das pessoas de outros lugares. É um espaço regido, dessa maneira, pela formalidade, diferentemente de Barreiras, que apesar das mudanças de forma, produzidas pela modernização contemporânea, ainda é um lugar que não perdeu o "espírito" da cultura local. Luis Eduardo Magalhães, ao contrário, é uma cidade no espaço baiano, mas não é uma cidade baiana ${ }^{44}$, haja vista que estão pouco presentes elementos da cultura nordestina, especialmente a baiana. A rua, tão presente na cultura nordestina, em LEM não se confirma como uma extensão da vida ou como o lugar da informalidade e do encontro (Haesbaert, 1997). Nos bairros residenciais de Luis Eduardo Magalhães predominam muito mais os traços da cultura sulista, em que o espaço de convivência social ocorre principalmente no âmbito do privado, no qual se valorizam mais os relacionamentos no interior da casa e da empresa do que os dos espaços públicos.

\footnotetext{
${ }^{44}$ Haesbaert (1997) já identificava em seu trabalho uma nítida separação e jogo de interesses de grupos regionais desde o inicio do então povoado de Mimoso do Oeste.
} 


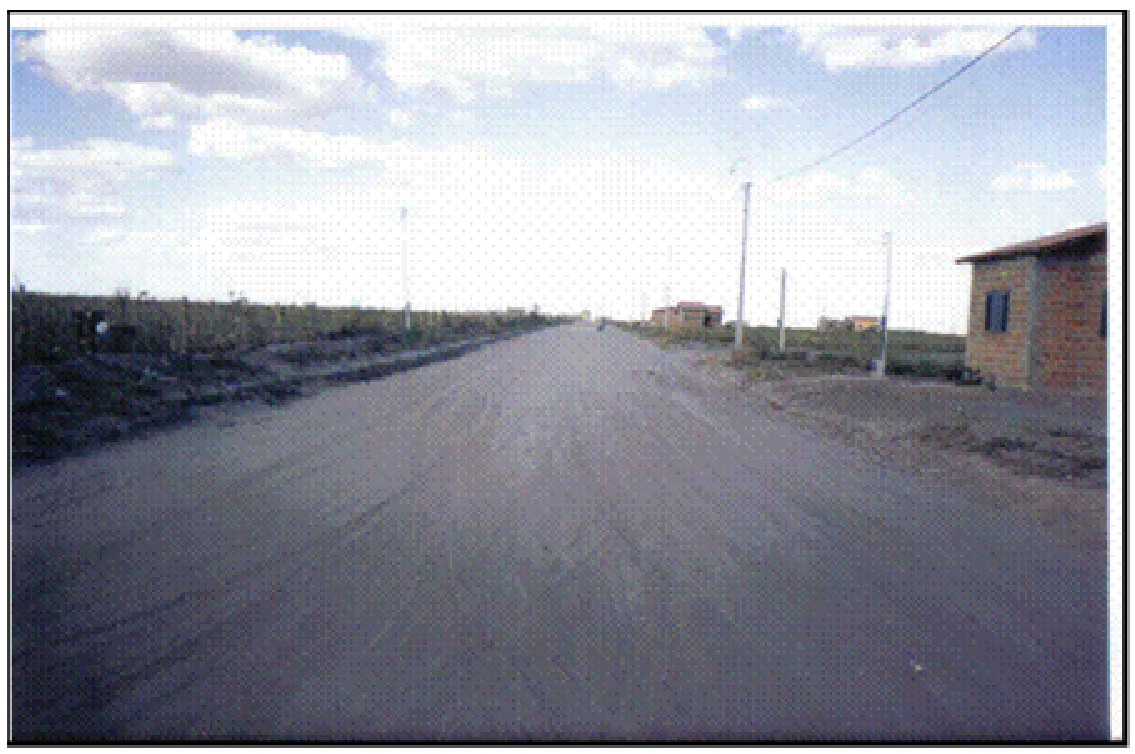

Foto 03 - Loteamento em formaça no municipio de Luis Eduardo Magalhề . Foto do autor, dezembro de 2005.

O movimento rarefeito de pessoas nas ruas dos loteamentos habitados predominantemente por sulistas demonstra a reduzida disposição desse grupo em explorar esses espaços públicos para expressar suas várias manifestações cotidianas. Conta-se, ainda, o fato do sulista representar os estratos sociais mais elevados do município, dificultando manifestações cotidianas com maior espontaneidade. Essa formalidade que sedimenta a identidade de Luis Eduardo Magalhães resulta da marcante influência sulista na construção da sociedade local. Tal presença da cultura sulista no espaço baiano já havia sido identificada por Haesbaert (1997: 184), quando tratou da instalação dos "gaúchos" em Barreiras, conforme nos esclarece:

"No sul, nas localidades do interior de onde provém a maioria dos migrantes [para Barreiras], as pessoas costumam colocar as melhores roupas quando saem para as compras ou simplesmente quando passam pelo centro da cidade. A rua e os espaços públicos (em especial a igreja, durante a missa de domingo) tornam-se um pouco a passarela onde desfila a riqueza (material) e a 'finura' de cada um. Para a classe média, ir ao centro 'de chinelo de dedo' é considerado vergonhoso. Tenta-se competir em boa aparência e formalismo os gestos e as falas muitas vezes são ensaiados e comedidos - qualquer deslize é logo denunciado. Ou seja, pretende-se que a rua seja também um espaço de ordem e disciplina, onde o individuo difunda, por extensão, predicados que cultiva dentro de casa." 
Assim como no rural, o mercado imobiliário urbano de Luis Eduardo Magalhães cresceu e tornou-se valorizado na mesma medida em que ampliava a demanda dos migrantes desembarcados nos últimos anos na cidade. A procura por imóveis elevou os preços dos terrenos numa velocidade somente acompanhada pela euforia dos que chegam esperançosos pelo enriquecimento numa terra de pretensas oportunidades. Um lote urbano de 12 x 35 metros quadrados, fora do centro da cidade, que em 2001 custava 3.500 reais, passou a custar 47 mil reais, em 2004. $\mathrm{Na}$ área central esse preço se eleva para aproximadamente 300 mil reais.

A valorização da terra urbana - controlada por um seleto grupo de proprietários pertencente ao que se costuma chamar de pioneiros do povoado de Mimoso do Oeste - é responsável também pela segregação dos indivíduos moradores em Luis Eduardo Magalhães. O alto preço de um lote seleciona os habitantes dos bairros. Para os mais pobres, a única possibilidade de moradia é o bairro de Santa Cruz, onde estão a quase totalidade dos migrantes nordestinos e onde se avistam os negros e os mestiços, diferentemente dos outros bairros mais ricos, onde se percebe predomínio da presença de brancos, principalmente, sulistas.

A expressão da cultura nordestina, em Luis Eduardo Magalhães, acontece preferencialmente no bairro de Santa Cruz. Naquela área se verifica outra lógica de funcionamento da cidade. As pessoas circulam pelas ruas num movimento intenso, em que a informalidade é a manifestação predominante. Encontram-se as barracas de lona, que compõem uma parte da paisagem local, comercializando uma variedade de mercadorias; ouve-se o som inconfundível das músicas regionais tocadas nos bares e/ou em camelôs num aparente caos sonoro; presenciam-se as conversas nas portas das casas com os vizinhos sem a pressa e a formalidade presentes em outros cantos da cidade. Estas expressões denunciam as oposições de um espaço urbano que se constrói pela segregação e pela divisão de grupos sociais e regionais.

O bairro de Santa Cruz é altamente adensado, um aglomerado de moradias precárias, instaladas em ruas estreitas, empoeiradas, com esgoto correndo a céu aberto (fotos 04 e 05). Às vezes, num mesmo lote de tamanho padrão de 400 metros quadrados, adotado para o plano urbanístico, são construídas duas ou três habitações para abrigar vários membros da família, 
atraídos para Luis Eduardo pelo sonho da cidade promissora. A falta de área para novas construções em Santa Cruz e o elevado preço dos terrenos urbanos, impossibilitando o acesso dos novos habitantes a moradias, já produz o parcelamento de lotes em outros bairros. Ademais, suscitou-se uma inquietação na sociedade local de que possam surgir movimentos organizados voltados para a conquista de moradias, interferindo na ordem da anunciada "cidade da prosperidade". Tal situação obrigou o poder público a elaborar, em 2005, uma nova legislação para o plano diretor urbano, obrigando as imobiliárias destinarem em seus novos loteamentos $20 \%$ dos terrenos para a população de menor poder aquisitivo. Permite-se, nesse caso, que os lotes comercializados sejam de dimensões menores. Evidentemente, para não desvalorizar os loteamentos destinados às classes mais abastadas, o loteador adota como estratégia formar áreas de habitação destinadas somente aos pobres, evidentemente, separadas de outros terrenos mais valorizados. O especulador cumpre, dessa maneira, a exigência da lei e ao mesmo tempo afasta a possibilidade dos mais endinheirados conviver com vizinhos indesejados.

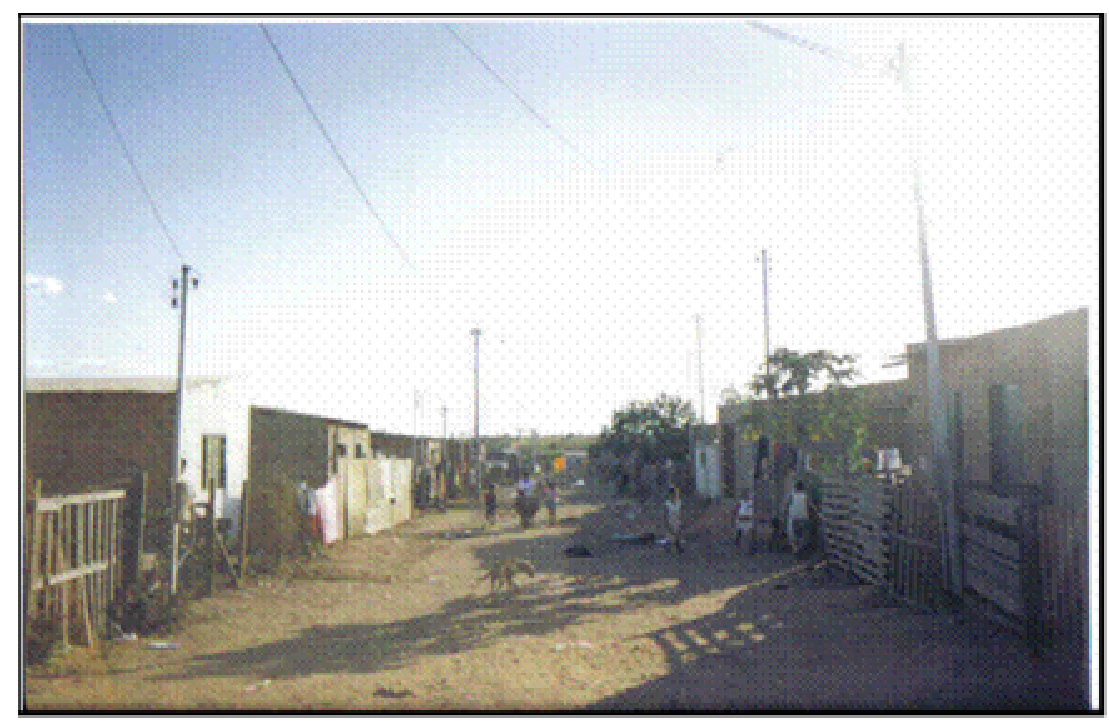

Foto 04 - Rua do bairo de Santa Cruz em Luis Eduardo Magalhăes area de grande conoentragâo de migrantes nordestinos. Foto do autor: julho de 2005. 


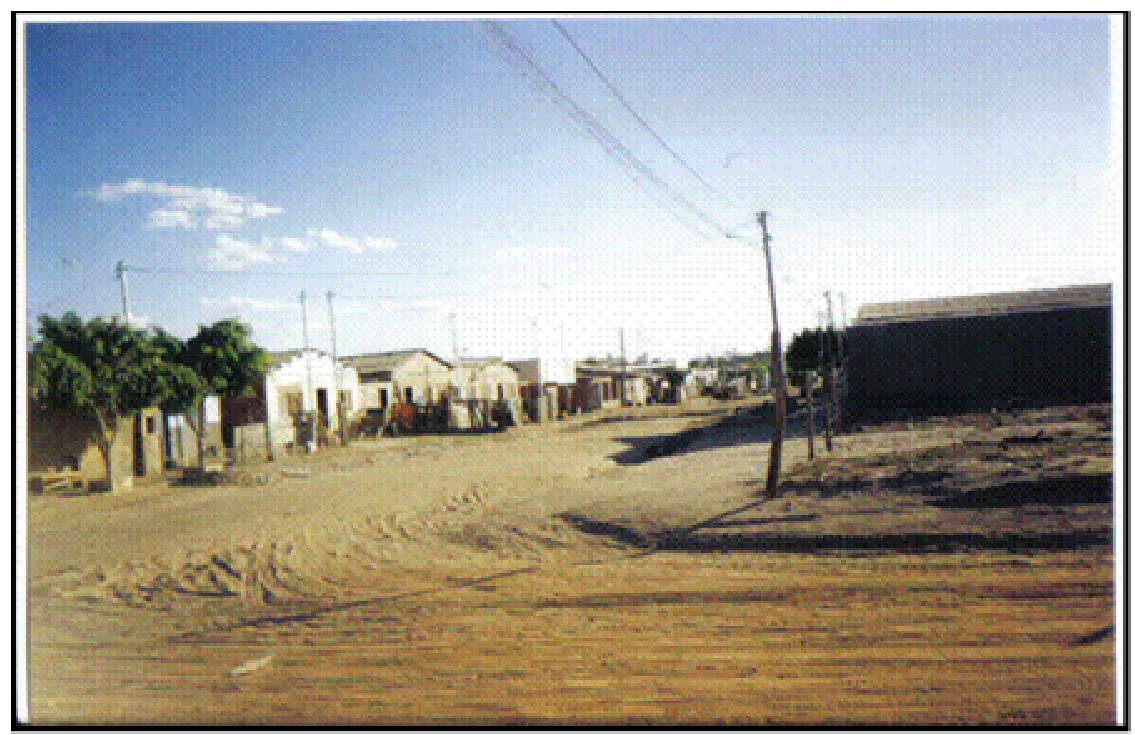

Foto 05 - Bairro de Santa Cruz - arrea com grandes carencias de infraestrutura urbana. Foto do autor, julho de 2005.

A especulação imobiliária, além de fomentar a segregação espacial construída pela seletividade dos que podem pagar mais pela terra, também gera uma área urbana com várias deficiências de infra-estrutura. A pressa com que os donos dos terrenos de Luis Eduardo Magalhães comercializam os novos loteamentos que, via de regra, são apenas recortes de arruamento separados em quadras - mas sem os outros beneficiamentos necessários de empreendimentos dessa natureza - produz uma cidade de carências, mesmo nos bairros mais ricos. Poucas são as áreas onde se observam asfaltamento das ruas, galerias pluviais, postes com iluminação pública e outros requisitos previstos em legislação. Vê-se, assim, que a cidade tomou forma sob a insígnia dos especuladores imobiliários, os quais definiram as regras da produção do espaço. O poder público chega depois tentando contornar as mazelas produzidas pelos interesses privados.

O discurso hegemônico das autoridades, e da população de maneira geral, é o de que Luis Eduardo Magalhães representa para os cerrados baianos um espaço pujante cuja construção, segundo alegam, está sendo feita, valorizando a eficiência e a organização dos que chegaram à Bahia e venceram todas as dificuldades através do trabalho. A idéia do pioneirismo reaparece em todas as falas dos que desembarcaram no oeste da Bahia e ascenderam socialmente. Coincidentemente, os outros que, por algum motivo, 
não obtiveram sucesso econômico nessa empreitada, inclusive os sulistas, são apagados da memória da cidade e de seus habitantes mais ilustres. Aqueles que obtiveram riqueza material são vistos como os vencedores, que diante de um lugar inóspito nos 1970 e 1980 conseguiram transformar, com "seu pioneirismo", coragem e muito trabalho, uma região atrasada em área de crescimento econômico.

Os discursos do triunfalismo e da eficiência profissional, que perpassam o imaginário de empresários e produtores agrícolas e se estendem para quase toda a sociedade, são também transferidos para os que ocupam a administração pública, gerenciada, aliás, em sua quase totalidade, pelos migrantes originários do centro-sul. O prefeito das duas únicas gestões, por exemplo, é originário de São Paulo; o mesmo ocorre com seu secretariado, em sua maioria, composto por pessoas de outras regiões. Os representantes da Câmara Municipal também não são baianos. Todos eles adotam o discurso de uma administração eficiente como diferenciador de outros municípios baianos, daí, avaliam, a receita de sucesso. São esses grupos, formados por representantes da agricultura moderna, os que assumem a liderança em Luis Eduardo Magalhães, caracterizando uma nova configuração de poder político regional. Como fica claro no depoimento de um migrante baiano morador na cidade:

"Olha, na verdade a classe dominante aqui é sulista. Os homens do poder são sulistas. Bem diferente de Barreiras, lá o pessoal do Sul não tem muita força política. Aqui é o contrário, os grandes empresários são os que mandam, nós nordestinos viemos para trabalhar, nós somos os proletários e eles são os empresários. O incrível é que eles são muito unidos, então, quando um chega, o outro dá uma força e logo eles crescem".

(Entrevista concedida em 30/12/2005, em Luis Eduardo Magalhães).

Intitulada por seus habitantes de "capital do agronegócio", Luis Eduardo Magalhães apresenta uma organização espacial diferenciada das outras cidades da região, não somente pelas características dos loteamentos residenciais, mas o planejamento urbano no seu conjunto segue o modelo das cidades modernas, com largas avenidas formando corredores para facilitar a circulação de veículos. Há um corredor central formado pela rodovia BR-242 
que corta a cidade no sentido norte-sul; às suas margens estão instaladas lojas comerciais de revenda de maquinários e peças automotivas, hotéis e postos de combustíveis, esses últimos com um movimento intenso de caminhões carregados ou que irão se abastecer de grãos. Isso indica que é a produção no campo quem define a dinâmica do lugar. A dez quilômetros da cidade, fora do perímetro urbano, em direção a Tocantins, encontra-se o Centro Industrial dos Cerrados (CIC), uma área de 250 hectares munida de infra-estrutura para o funcionamento de empresas, algumas delas já instaladas, tais como a Mauricéia do Nordeste, fábrica de ração e integrado de frango; Grupo Taji, fábrica de extração de óleo de algodão; DaSilveira South América Ltda., fábrica de equipamentos para bovinocultura leiteira e confinamento; dentre outras. Surgem também, às margens da BR-242, loteamentos cujos preços dos terrenos variam de 30 a 40 mil reais. Além disso, são lançados vários condomínios fechados de alto padrão, como o "Pedra dos Sonhos", anunciado no município como "o mais moderno complexo residencial da América Latina”. Tal condomínio, cujos moradores são ricos agricultores e executivos das empresas instaladas no município, possui modernos equipamentos de lazer, com destaque para campo de golfe, kartógramo, restaurante de cozinha internacional etc. O estilo de vida é semelhante ao que se observa nos residenciais de algumas cidades norteamericanas, copiado pelos diversos condomínios fechados espalhados pelo Brasil, ou seja, no intramuros do condomínio cria-se toda uma estética de se morar e de se comportar: as casas são amplas e seguem uma arquitetura mais ou menos padronizada; a garagem, disponibilizando vagas para vários carros, tornou-se um complemento indispensável à moradia. O automóvel, nesses lugares, é o principal símbolo de status na concorrência com os vizinhos. A área é vigiada por câmeras digitais e um visitante somente pode acessar o interior dos condomínios após a sua rigorosa identificação. No condomínio Pedra dos Sonhos, um lote contendo uma casa de alto padrão é vendido por, aproximadamente, 1,5 milhão de reais, preço compatível com os dos mais luxuosos condomínios das áreas mais valorizadas do eixo São Paulo-Rio de Janeiro (fotos 06 e 07). 


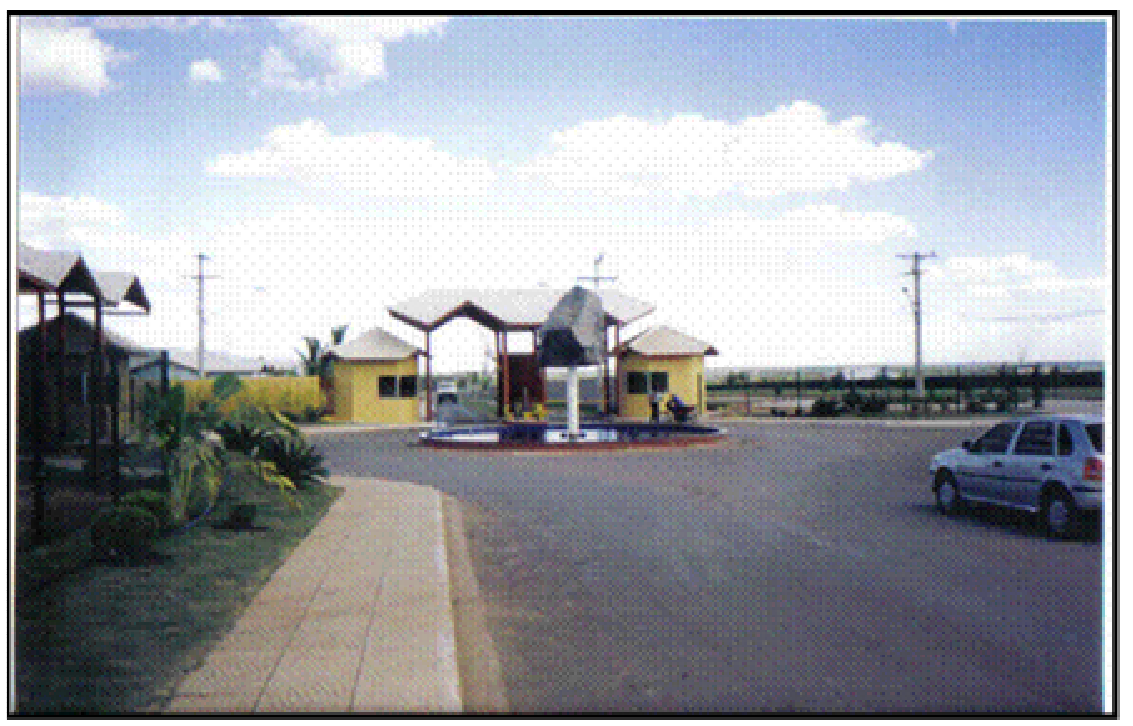

Foto 06 - Entrada de um dos condominios em Luis Eduardo Magalhäes. Foto do autor, dezembro de 2005.

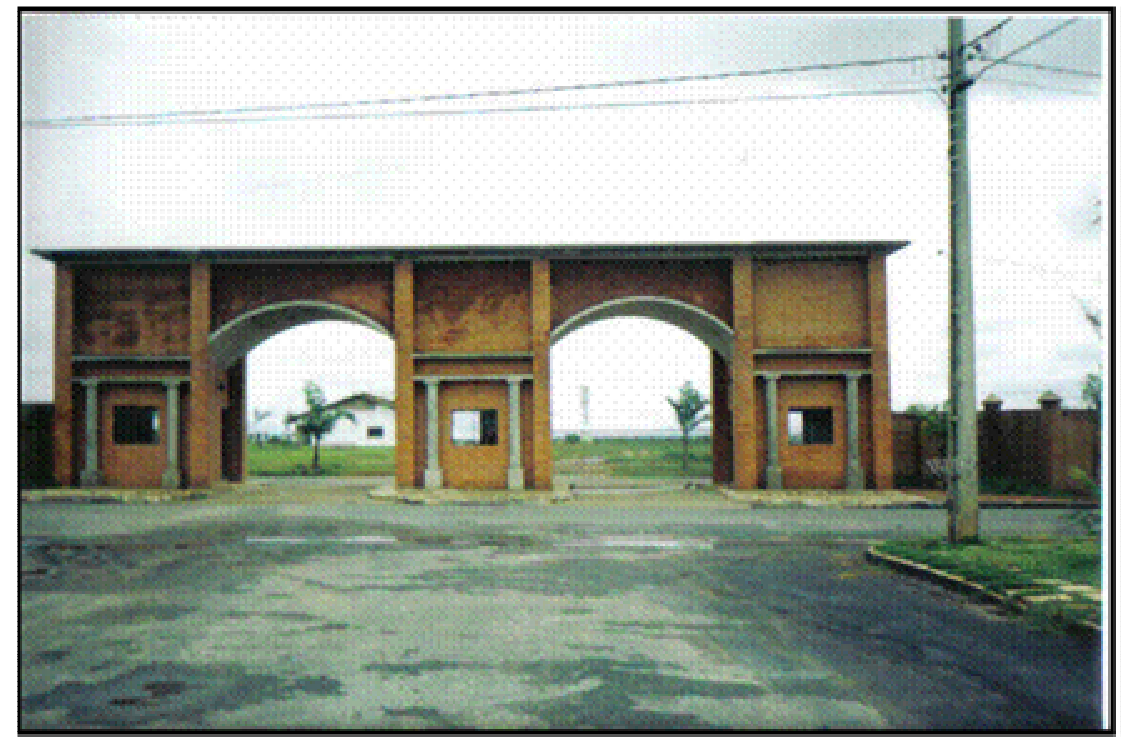

Foto $\mathbf{0 7}$ - Entrada de condominio ainda em formaçăo no municipio de Luis Eduardo Magalhâes. Foto do autor, dezembro de 2005. 
Além da proliferação de condomínios fechados, a cidade experimenta um processo inicial de verticalização. Existem ou estão em construção edifícios para moradias e escritórios, muitos deles ultrapassando oito andares, cujos preços, assim como nos demais casos de comércio de imóveis, são cotados em sacas de soja. Os prédios de apartamentos lançados destinamse, prioritariamente, à classe média urbana do município; neles se vende também a idéia da segurança e do lazer, exclusivos aos condôminos.

A população de Luis Eduardo Magalhães que, em 2000, era em torno de 20.000 habitantes; no final de 2005, esse número já se aproximava, segundo estimativas da prefeitura local, de 50.000 habitantes. Nesse rápido crescimento surgiram situações inusitadas no município: o pleito eleitoral, por exemplo, ocorrido em 2004 estava até inícios de 2006 sob investigação judicial, pois se detectou o comparecimento de mais eleitores do que a população registrada no Censo oficial do IBGE, de 2000. Nesse caso, compareceram para votar mais de 23 mil eleitores e um número semelhante de pessoas que foram às sessões de votação para justificar a ausência de sua sede eleitoral. Ou seja, havia no município, no dia da votação, morando ou em trânsito, duas vezes mais eleitores do que o número de habitantes constatado no período censitário. Essa diferença de números somente pode ser explicada pelo grande fluxo de pessoas nos últimos cinco anos que se dirigiram para Luis Eduardo, algumas fixando residência no município, outras apenas com moradia temporária. A primeira situação é a de maior ocorrência, haja vista o grande deslocamento de população em busca de trabalho e lugar para morar.

Além dos migrantes que chegam a Luis Eduardo Magalhães com melhor poder aquisitivo, inserindo-se mais rapidamente no mercado de trabalho ou que com seu capital procuram iniciar um negócio, adquirindo com maior facilidade imóveis residenciais e/ou comerciais, existem aqueles que chegam desprovidos de capital e de qualificação. Estes últimos possuem escassos recursos e desembarcam no município com a esperança de adquirir logo uma ocupação na própria cidade ou nas fazendas, como trabalhadores temporários. Forma-se, nesse caso, freqüentemente, uma rede migratória constituída de população nordestina de estados vizinhos, como o Piauí, ou de outros municípios baianos. Migram porque os familiares, os amigos etc. que já 
se estabeleceram na cidade incentivam os demais a realizarem o mesmo percurso. Muitos conseguem ocupações por intermédio de um familiar morador no município, como fica claro no depoimento que segue:

"Normalmente, vem uma pessoa para trabalhar, aí já fica morando aqui, daí um parente já chama outro parente (...) quando uma empresa precisa de mãode-obra que ele sabe ai ele faz contato com parentes, vem, trabalha, ganha um dinheirinho e volta pra casa, outros acaba ficando e constrói uma casinha no terreno do parente"

(Entrevista concedida por gerente de hotel em Luis Eduardo Magalhães, em dezembro de 2005).

Luis Eduardo Magalhães nasce como cidade essencialmente monetarizada, na medida em que se organiza a partir do e para o consumo consuntivo e produtivo (Santos, 1993). Ela se abastece de profissionais de grande qualificação técnica que atendem tanto às demandas das empresas e dos produtores agrícolas quanto da população de maior poder aquisitivo. É a área de maior consumo per capita de telefonia celular do estado da Bahia e o de maior PIB entre os novos municípios criados desde de 1999. Funcionam duas faculdades particulares no município e duas estão sendo instaladas, oferecendo cursos superiores de várias modalidades do agronegócio, além de MBA em gestão empresarial do agronegócio e pós-graduação em administração de agronegócios com ênfase no mercado internacional. É a única cidade do Nordeste a sediar a Feira Internacional de Tecnologia Agrícola (Agrishow). A sua segunda versão, realizada em junho de 2005, movimentou 220 milhões de reais. A capacidade de dar respostas econômicas imediatas às demandas das empresas instaladas, que exigem a presença das condições materiais com conteúdo informacional e científico, torna Luis Eduardo Magalhães mais habilitada do que qualquer outra aglomeração urbana da região para cumprir o papel exigido pelo novo capital. Representa, nesse sentido, um novo conjunto de cidades do Brasil agrário, as quais deixam de ser uma "cidade no campo" para se transformar numa "cidade do campo", conforme definiu Santos (1993: 52): 
"A cidade torna-se o locus da regulação do que se faz no campo. É ela que assegura a nova cooperação imposta pela nova divisão do trabalho agrícola, porque obrigada a se afeiçoar às exigências do campo, respondendo às suas demandas cada vez mais prementes e dando-lhe respostas cada vez mais imediatas. Como o campo se torna extremamente diferenciado pela multiplicidade de objetos geográficos que o formam, pelo fato de que esses objetos geográficos têm um conteúdo informacional cada vez mais distinto (o que se impõe, porque o trabalho no campo é cada vez mais carregado de ciência) tudo isso faz com que a cidade local deixe de ser cidade no campo e se transforme na cidade do campo".

Esses fatores confirmam o município como o principal centro econômico dos cerrados nordestinos, ao mesmo tempo em que colocam Barreiras numa posição secundária para os interesses do capital agropecuário. Apesar de se manter com uma maior concentração de população e de empresas, Barreiras vem perdendo rapidamente receitas para Luis Eduardo Magalhães, indicando uma inversão nos papéis de centralidade econômica no oeste da Bahia, conforme se verificou no caso da produção de soja e se observa na arrecadação do ICMS que consta na tabela 05.

\begin{tabular}{|c|c|c|}
\hline Tabela $05-$ & \multicolumn{2}{|c|}{ Eduardo Magalhães $(1995-2003)-$ em reais } \\
\hline Anos & Barreiras & Luis Eduardo Magalhães \\
\hline 1995 & $32.659 .617,89$ & --------י \\
\hline 1996 & $39.304 .453,00$ & ---------- \\
\hline 1997 & $40.881 .874,81$ & ---------- \\
\hline 1998 & $32.469 .103,23$ & --------- \\
\hline 1999 & $34.073 .278,49$ & --------- \\
\hline 2000 & $38.832 .805,91$ & 25,00 \\
\hline 2001 & $26.151 .476,00$ & $21.910 .731,00$ \\
\hline 2002 & $26.955 .448,00$ & $26.605 .167,00$ \\
\hline 2003 & $29.628 .479,00$ & $40.703 .846,00$ \\
\hline
\end{tabular}

Fonte: Superintendência de Estudos Econômicos e Sociais da Bahia (SEI) - 1995-2003. 
Os dados acima apontam que a emancipação de Luis Eduardo Magalhães reverteu-se numa perda de aproximadamente $30,5 \%$ da arrecadação de Barreiras, proveniente do ICMS; em contrapartida, Luis Eduardo Magalhães começa arrecadando 21.910.731 reais, em 2001, e passa logo depois para 40.703.846 reais, em 2003. Ou seja, em dois anos obteve um aumento de $86,2 \%$ na participação de tal imposto, ultrapassando largamente a arrecadação de Barreiras.

A liderança econômica de Luis Eduardo nos indica que a produção agrícola moderna torna-se a predominante na sub-região e é ela a definidora dos padrões, tanto no uso dos sistemas técnicos, quanto na difusão de comportamentos sociais. Esse processo hegemônico e homogeneizador sucumbe às outras formas de produção da vida, relegando-nas a um plano inferior. Diferentemente das cidades baianas formadas antes da expansão do agronegócio na sub-região, em Luis Eduardo não existe a festa com as mesmas dimensões simbólicas que elas representam para cultura local. É a economia quem impõe as formas de manifestações culturais que as pessoas deverão seguir. Consta, por exemplo, no calendário festivo da cidade, o Baile do Havaí e a festa da colheita (ou Agrifest). Esta última ocorre no mesmo período da Agrishow e é organizada pelo poder público junto com produtores agrícolas para comemorar os resultados da produção agrícola moderna e a feira de agronegócios. No evento acontecem apresentações de bandas de forrós que aparecem na grande mídia e de grupos de músicas folclóricas do Sul do Brasil. Acontecem também festas nos principais hotéis e corridas de automóveis realizadas no autódromo construído na cidade. Esse tipo de evento, entretanto, indica que a festa ganha outros sentidos nos cerrados baianos, não representa mais associação ao tempo da natureza e às manifestações religiosas locais. Em Luis Eduardo Magalhães é o poder do dinheiro quem decide o que é importante de ser apropriado pelo tempo livre das pessoas, oferecendo a elas expressões culturais padronizadas, as quais são mediadas pelo mundo da mercadoria. Nessas ocasiões, o conteúdo simbólico manifestado pela sociedade agrária camponesa não faz mais sentido nesse novo rural, visto que agora o que se torna interessante nas formas de mediações dos grupos sociais emergentes é o consumo dos fetiches produzidos pela sociedade da mercadoria. 
As manifestações culturais que resultam de uma tradição que se instala em Luis Eduardo Magalhães não são verdadeiramente constituídas no lugar, mas chegaram junto com os migrantes sulistas. Os principais eventos nesse sentido ocorrem numa associação direta com as tradições do Sul do Brasil. A cidade abriga um grande Centro de Tradições Gaúchas (CTG) denominado "Sinuelo dos Gerais" (foto 08), numa área de 25 hectares, onde estão os equipamentos destinados à divulgação da cultura sulista: um salão para as festas, recinto para apresentação e competição de cavaleiros (pistas de laço), churrasqueiras etc. Anualmente, no mês de setembro, reúnem-se no CTG para participar da "Festa Criola" ou "Invernada" cerca de três mil sulistas, migrantes das regiões de fronteira agrícola e pessoas que saem diretamente do Sul do Brasil para prestigiar a festa. Há, nos quatro dias de evento, torneios de laços no qual o cavaleiro demonstra suas perícias no lombo de um cavalo, ao estilo da cultura crioula; apresentação de músicas e danças típicas, em que os figurantes trajam vestimentas características dos grupos folclóricos gaúchos; e os tradicionais churrascos oferecidos aos participantes. Tais atividades são esclarecedoras de que aquele espaço se organiza demonstrando uma outra lógica econômico-cultural, da qual participa um outro grupo regional sob a subordinação do capital agroindustrial.

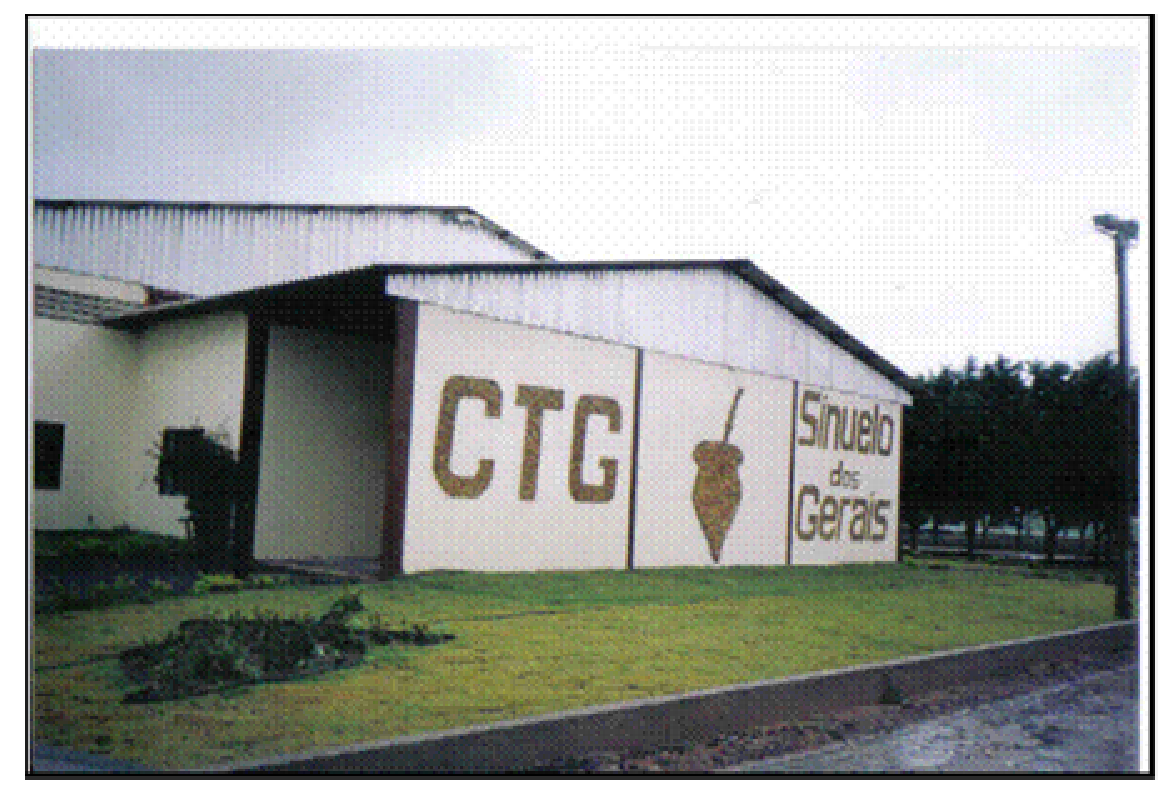

Foto 08 - Centro de Tradiçóes Gaúchas (CTG) em Luis Eduardo Magalhases. Foto do autor, dezembro de 2005. 


\section{4 - A expansão da agricultura moderna nos cerrados maranhense}

Os primeiros agentes modernizadores contemporâneos chegaram ao sul do Maranhão na década de 1970, valendo-se de recursos disponibilizados pela Superintendência de Desenvolvimento do Nordeste (SUDENE) através dos programas de desenvolvimento regional. Os grupos beneficiados com linhas de créditos estavam associados, sobretudo, à pecuária melhorada e à lavoura, inicialmente com a produção de arroz de sequeiro (Diniz, 1984). Os sinais da modernização contemporânea, no entanto, são mais evidentes a partir de meados dos anos 1980, quando surgem as primeiras cifras de produção de soja no Maranhão, com destaque para o sul do estado, onde se encontram os cerrados. É na década dos 1990, no entanto, que esse fenômeno se consolida, pois a produção dessa oleaginosa apresenta substancial expansão (tabela 06) nas terras sul-maranhense onde é plantada.

\begin{tabular}{|c|c|c|c|}
\hline \multicolumn{4}{|c|}{ Tabela 06 - Série histórica das safras de soja - Estado do Maranhão } \\
\hline Anos & $\begin{array}{c}\text { Área Plantada } \\
\text { (mil hectares) }\end{array}$ & $\begin{array}{c}\text { Produção } \\
\text { (mil toneladas) }\end{array}$ & $\begin{array}{c}\text { Produtividade } \\
\text { (kg/ha) }\end{array}$ \\
\hline $1990 / 91$ & 4,6 & 8,3 & 1.800 \\
\hline $1991 / 92$ & 21,1 & 25,3 & 1.201 \\
\hline $1992 / 93$ & 42,7 & 91,2 & 2.135 \\
\hline $1993 / 94$ & 62,8 & 138,2 & 2.200 \\
\hline $1994 / 95$ & 91,7 & 169,6 & 1.850 \\
\hline $1995 / 96$ & 89,1 & 199,6 & 2.240 \\
\hline $1996 / 97$ & 120,0 & 252,0 & 2.100 \\
\hline $1997 / 98$ & 144,0 & 302,4 & 2.100 \\
\hline $1998 / 99$ & 162,7 & 390,5 & 2.400 \\
\hline $1999 / 2000$ & 175,7 & 439,3 & 2.500 \\
\hline $2000 / 01$ & 210,0 & 483,0 & 2.300 \\
\hline $2001 / 02$ & 238,3 & 540,9 & 2.270 \\
\hline $2002 / 03$ & 274,0 & 654,9 & 2.390 \\
\hline $2003 / 04$ & 342,5 & 924,1 & 2.698 \\
\hline $2004 / 05$ & 375,0 & 997,5 & 2.660 \\
\hline
\end{tabular}

Fonte: Conab - Série Histórica de Produção, Área Plantada e Produtividade - Safras 1990/91 a 2004/05. 
Como se observa na tabela acima, a produção de soja foi ano a ano se destacando na produção agrícola maranhense, ocorrendo um aumento expressivo de 1990 a 2004, situação semelhante foi detectada com relação à expansão da área de plantação de soja.

O Estado participou ativamente do início desse processo, através de políticas de incentivos fiscais e de créditos subsidiados, principalmente recursos advindos de fundos de financiamentos federais, como o Fundo Constitucional de Financiamento do Nordeste (FNE), administrado pelo Banco do Nordeste (BNB); e do Fundo de Desenvolvimento do Nordeste (FNDE), da antiga SUDENE (atualmente ADENE). A intervenção das políticas públicas nacionais também ocorreu no nível da unidade da federação, através de outros mecanismos de incentivos fiscais às empresas, principalmente àquelas voltadas para o comércio exterior, tais como o Sistema de Apoio à Indústria e ao Comércio Exterior do Estado do Maranhão (SINCOEX), e o de empresas Especializadas em Comércio Exterior (ECEX) (Mesquita, 2002). Além disso, o Maranhão foi o primeiro estado brasileiro a abolir o ICMS para exportação de soja, em 1994. Isenção fiscal que posteriormente foi estendida, por lei federal, ao restante dos estados exportadores brasileiros, amparados pela denominada "Lei Kandir", de 1995.

O impulso à agricultura capitalista moderna no sul do Maranhão foi conduzido também por migrantes, predominantemente, sulistas ${ }^{45}$. Os registros históricos apontam o ano de 1974 como o início do desembarque das primeiras famílias do Sul do Brasil em terras dos cerrados maranhenses, após a visita do então prefeito de Balsas ao Rio Grande do Sul, a fim de divulgar para os agricultores gaúchos o potencial daquelas terras. Esse fenômeno ganha maiores dimensões, no entanto, a partir de meados dos anos 1980 , com o acréscimo de levas de migrantes sulistas instalados nos platôs planos dos gerais de Balsas.

Contam-se, ainda, para o avanço da agricultura moderna nos cerrados maranhenses, a possibilidade de empresas e agricultores adquirirem terras a baixos preços em grandes extensões e a alocação de recursos provenientes

\footnotetext{
${ }^{45} \mathrm{Em}$ toda a área dos cerrados do Nordeste houve a participação também de nordestinos nos projetos, principalmente como agentes modernizadores amparados por recursos da SUDENE para o melhoramento de rebanho bovino, implantação de projetos de reflorestamento e de produção de arroz em sistema semi-intensivo mecanizado (Diniz, 1984).
} 
do Prodecer, em sua terceira etapa (Prodecer III) destinados ao desenvolvimento de projetos agrícolas na sub-região. A participação desse programa no Maranhão limitou-se à participação em um projeto de colonização agrícola implantado, em 1995, no município de Balsas, envolvendo 40 famílias de agricultores, sendo vinte sulistas e vinte de outras regiões. Tal projeto foi executado sob a coordenação da Cooperativa Agropecuária Batavo ${ }^{46}$, de Castro- PR; da Campo - Companhia de Promoção Agrícola; e do Banco do Nordeste. O assentamento, conhecido como "Colônia da Batavo", ocupava uma área de 40 mil hectares, na Chapada das Mangabeiras, a uma distância de cerca de 200 quilômetros da sede do município, nos limites com o estado do Tocantins. Essa agrovila, atualmente distrito de Balsas, apresentou crescimento de seu núcleo urbano decorrente da instalação das famílias de produtores, onde se criou uma estrutura de pequena cidade, ocorrendo, inclusive por parte de seus moradores, manifestação de emancipação da área, onde nasceria o pretenso município de Campos Gerais (Melo \& Mota, 2004).

O projeto recebeu importantes investimentos advindos do acordo de cooperação nipo-brasileira, destinados à aquisição de terras e maquinários para os produtores, à instalação de silos e ao custeio da plantação de soja, arroz, milho e fruticultura. O sucesso desse projeto, entretanto, não se concretizou; o sistema cooperativo se desintegrou alguns anos depois. Poucos dos colonos permanecem atualmente na área adquirida, a maioria perdeu suas terras, as instalações e os maquinários para os bancos financiadores, outros venderam ou arrendaram seus lotes para a SLC Agrícola, empresa de grande porte produtora de soja. Segundo técnicos da Embrapa, alocados na unidade de Balsas, o projeto não deu certo por acumular erros em sua concepção: falta de estratégia adequada; escolha de produtores sem estabelecer critérios mais ajustados aos objetivos do projeto, pois muitos não eram produtores em sua origem; preços elevados dos lotes não condizentes com o poder aquisitivo de alguns agricultores; além disso, o isolamento da área, necessitando percorrer grandes distâncias até a sede do município de Balsas.

\footnotetext{
${ }^{46}$ As famílias sulistas foram selecionadas pela Cooperativa Batavo.
} 
O fato de veicular a implantação de um projeto financiado pelo Prodecer de proporções financeiras elevadas funcionou, no entanto, como chamariz para produtores de outras regiões. Além disso, o avanço das pesquisas em soja e o aparecimento de novas cultivares, adaptadas a lugares de temperaturas mais elevadas, contribuíram para o aumento substancial da produtividade da região. Isso também foi responsável pelo interesse de agricultores de outras regiões pelo sul do Maranhão.

Como vimos anteriormente (primeiro capítulo), o sistema de escoamento é um outro fator diferencial de atração de agricultores empreendedores da agricultura capitalista e de empresas para essa subregião, haja vista sua proximidade com o Corredor de Exportação Norte (mapa 06). Soma-se a isso o interesse das grandes empresas em comprar a produção dos agricultores diretamente na região, sendo que elas criaram estratégias para a instalação de suas unidades produtivas ou de recebimento de grãos. Aproveitam, dessa forma, o fato de poder conciliar a proximidade das áreas produtoras de matérias-primas com a possibilidade de acessar vias de escoamento que atingem mais rapidamente os portos exportadores e o mercado consumidor interno (Castro, s/d). Essa estratégia é confirmada quando se verifica que, nos últimos anos, algumas dessas empresas instalaram nos cerrados nordestinos plantas de fábricas ou grandes centros armazenadores de soja, espalhados em áreas próximas da intensa produção agrícola. Além disso, para garantir maior agilidade, dispõem de serviços de logística junto aos terminais marítimos. Destacam-se, nesse caso, a Cargill e a Bunge Alimentos, empresas que montaram unidades receptoras de grãos no complexo portuário de Itaqui/Ponta da Madeira. As duas empresas possuem, cada uma, silos com capacidade de armazenamento de 50 mil toneladas.

O interesse das grandes empresas de processamento de soja pelos cerrados nordestinos é patente. No caso do município de Balsas, estão instaladas várias delas, como a ADM, a Bunge Alimentos, a Cargill, a Multigrain, dentre outras. Essas empresas arrematam dos agricultores a quase totalidade da produção de soja dos cerrados do Maranhão, da Bahia, do Piauí e de Tocantins, estabelecendo com tais agricultores uma relação comercial de subordinação, em que as dificuldades de desprendimento delas são enormes. 
Além dos grandes grupos econômicos, empregadores de pouca mãode-obra, e das pequenas empresas, Balsas atrai levas de migrantes, não somente agricultores sulistas, mas também trabalhadores empobrecidos da área rural ou de outros municípios da região. A variação positiva de crescimento demográfico do município foi de $49,89 \%$, entre 1991 e 2001 ; isto é, de 41.648 habitantes, em 1991, passa para 60.163 habitantes, em $2000^{47}$. Foi o município dos cerrados maranhenses com maior acréscimo de população (taxa média de crescimento anual de $3,75 \%$ ), e também o que mais estendeu sua área urbana, apresentando, em 2000, uma taxa de urbanização $83 \%$, a mais elevada da sub-região.

A concentração de população em Balsas, sobretudo na área urbana, indica que esse município exerce um papel de centralidade das atividades econômicas, atendendo as demandas do consumo produtivo e consuntivo dos cerrados maranhenses. Cálculos elaborados pelo BASA/IPEA/ANPEC (2002), a partir de fontes do IBGE/RAIS de 2000, apontavam Balsas como o principal município da sub-região em ocupação de mão-de-obra, com 4.198 ocupações formais, distribuídas pelos seguintes grandes setores econômicos: 9,29\%, na indústria; $34,28 \%$, no comércio; 44,50\%, em serviços; e 11,93\%, na agropecuária. Levantamentos mais recentes do Cadastro Central de Empresas (IBGE) apontam um acréscimo na ocupação da população de Balsas (gráfico 07), atingindo, em 2003, um total de 8.989 pessoas ocupadas, porém em 2004 houve uma redução do pessoal ocupado, passando para 8.539 pessoas. As atividades relacionadas ao comércio de peças automotivas, de objetos pessoais e domésticos aparecem como as que mais contratam, absorvendo em 1998 cerca de 3.665 pessoas, esse número acresceu para 3.943 pessoas, em 2003. Esses números confirmam que o setor de serviços é o de maior dinamismo no município. A administração pública, que em outros momentos predominava na economia dos municípios nordestinos, ocupando pessoas sobretudo no interior, perde posição para outras atividades mantidas pelas empresas do agronegócio. Entretanto, mesmo reduzindo seu papel na geração de ocupações, o setor público continua absorvendo uma parcela

\footnotetext{
${ }^{47}$ Fonte: Censos demográficos de 1991 e 2000. As porcentagens que seguem foram obtidas a partir de cálculos elaborados pelo BASA/IPEA/ANPEC. In: Projeto de contribuição ao desenvolvimento dos principais arranjos produtivos locais potenciais dos estados da Amazônia - Estado do Maranhão, dezembro de 2002.
} 
significativa da população. No município de Balsas, em 2003, a atividade de administração pública, defesa e seguridade social (segundo o tipo de classificação do IBGE) ocupava 2.817 pessoas, sendo que, em 1997, esse número era de 314 pessoas. Esses dados confirmam que o Estado vai adequando suas estruturas conforme as demandas do capital.

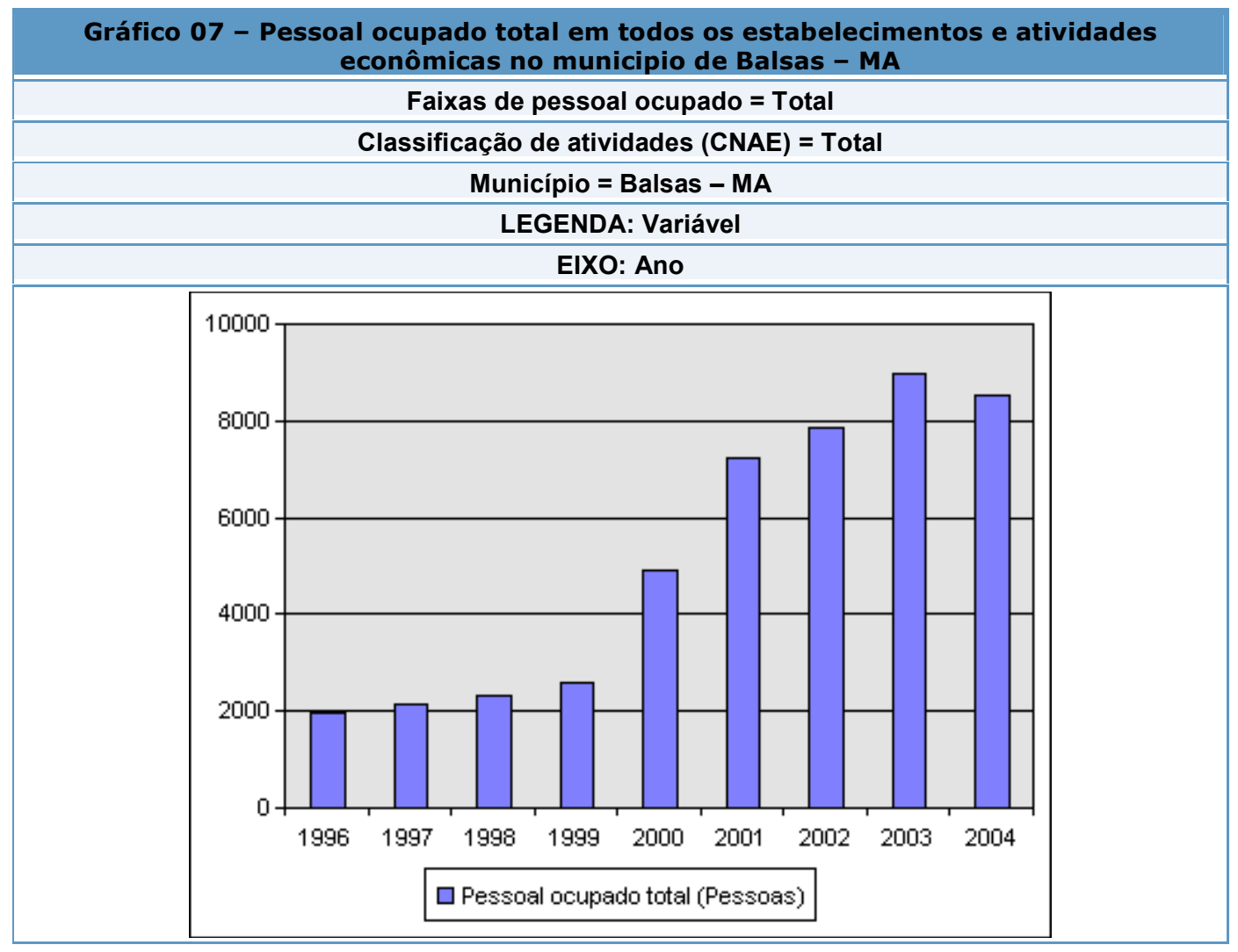

Fonte: IBGE - Cadastro Central de Empresas, 1996-2004

A presença de novos empreendimentos no município aqui analisado, com acréscimo de alguns postos de trabalho, é conseqüência do processo de ampliação da agricultura empreendedora capitalista que necessita criar, nas cidades locais, atividades para atender às novas modalidades de consumo.

Essa sensação de uma aparente prosperidade econômica valorizada nos discursos dos vencedores não revela, entretanto, as contradições próprias do avanço do sistema produtor de mercadorias. A tentativa de homogeneização pela mercadoria não se fez sem antes acionar os meios coercitivos para transformar terra e trabalho em capital.

Além de mobilizar agricultores empreendedores para produzir mercadorias agrícolas de exportação e gerar mão-de-obra local assalariada, o 
outro caminho para a aceleração da modernização contemporânea sulmaranhense foi o de transformar também a terra em mercadoria. Essa iniciativa aconteceu no mesmo instante ou um pouco antes da instalação dos primeiros sulistas nessa sub-região. Ou seja, também na década de 1970 ocorre a expansão da apropriação irregular das terras devolutas, compreendendo vastas extensões de áreas daquele estado. A maioria delas foi transferida para grupos privados de maneira ilegal, sob a articulação de uma eficiente rede de grilagem que já atuava no leste maranhense desde a década de 1960 e que transferiram seus métodos também para o sul do estado e outras áreas dos cerrados nordestinos (Asselin, 1982). Surgiram dessa rede de falsários as empresas de colonização cujos tentáculos se fixavam dentro de órgãos governamentais legislativos, executivos e judiciários, cartórios, fazendeiros locais etc. No caso das terras sul- maranhenses, uma das empresas que comercializava terras devolutas possuía sua sede em Goiânia, mas mesmo assim conseguia articular com agentes locais para transferir terras para os primeiros sulistas que desembarcavam na região. $A$ forma como ocorreu a transferência de terras públicas para mãos privadas é relatada no trecho que segue:

“Desse modo, com a chegada dos 'gaúchos', que procuravam terra para se fixarem, iniciou-se um intenso processo de grilagem. O primeiro momento de ocupação das terras de Balsas se desdobra em três etapas: a primeira, passando pela intermediação de uma certa empresa particular de colonização de Goiás que limpa e 'vende' terras públicas; a segunda, onde aparece a figura dos grileiros; a terceira, compra e venda de terras. Aqui temos os especuladores. Na região que a pesquisa aconteceu [sul do Maranhão] as três etapas foram executadas pela empresa acima mencionada. Neste caso, a situação de grilagem nas duas etapas [iniciais], implicou num apossamento ilegal daquelas terras, sendo que na segunda fase o grileiro compra uma posse e forja um título que lhe permite açambarcar enormes extensões" (CSEM, 2000: 54).

O governo maranhense - em sintonia com as políticas federais comandas pelo regime militar - teve fundamental importância em criar os mecanismos necessários para que os grupos econômicos se sentissem atraídos por aquelas terras, principalmente as do centro-oeste e sul do estado onde se concentram áreas propícias às atividades agrícolas modernas. 
Soma-se à Lei de Terras, de 17 de junho de 1969 (Lei $\mathrm{n}^{\circ}$ 2.979), a Comarco - Companhia Maranhense de Colonização, criada em 06 de dezembro de 1971 (Lei n 3.230); e a Colone - Companhia de Colonização do Nordeste, formada em 1972. Estes são alguns dos principais mecanismos adotados pelo Estado para empreender projetos de colonização. A proposta seria transformar parte dessas terras em projetos de assentamento para pequenos agricultores; a outra parcela (de maior extensão) se destinaria para grupos privados, predominantemente grandes empresas, as quais pretensamente investiriam em projetos agropecuários, industriais ou extrativos. Além disso, a sua aquisição ocorreria a preços bastante reduzidos e com incentivos financeiros governamentais (Pedrosa, s/d). Essas facilidades de acesso a terras e a recursos públicos motivaram poderosos grupos econômicos a se interessar pelo Maranhão. Por outro lado, esses mesmos grupos desencadearam uma intensa apropriação das terras devolutas a partir de uma violenta ofensiva sobre os posseiros, expulsando-nos dessas áreas. Esses trabalhadores posseiros tiveram, a partir de então, que se deslocar para as sedes dos municípios da sub-região, como a de Balsas, ou passaram a se sujeitar às novas relações de trabalho mantidas nas fazendas das grandes empresas, freqüentemente em condições precarizadas (Paula Andrade et al., 1995).

Conta-se ainda nesse contexto as empresas de celulose e de exploração mineral que optaram principalmente pelo oeste maranhense, região de constantes conflitos agrários e de ocorrência generalizada de trabalho forçado, sobretudo em fazendas de empresas produtoras de carvão vegetal.

A presença dos sulistas e de empresas interessados na exploração agropecuária ocorre principalmente no alto Parnaíba maranhense (mas também no oeste do estado). Esse movimento desencadeou uma ampla apropriação privada das terras públicas, repassadas posteriormente para grupos econômicos que chegaram ao Maranhão, sobretudo nos anos $1980 \mathrm{e}$ 1990. Parte, todavia, dessas terras voltaram novamente para o Estado mediante desapropriações realizadas pelo Incra, mas somente após uma grande valorização, em alguns casos com incorporação de ágio superior a $24.000 \%$, sucedido entre o momento de aquisição da terra e o seu repasse 
para o Incra, alguns anos depois (Pedrosa, s/d). Tais procedimentos foram adotados tanto por indivíduos quanto por empresas. Dentre estas últimas constam nomes importantes, tais como o Grupo Cacique, o Pirelli e a Fundação Rubem Berta, controladora da então Varig Agropecuária. Algumas dessas empresas negociaram terras não somente no Maranhão, mas estiveram presentes também no sul do Piauí, desenvolvendo estratégias semelhantes também naquele estado, ou seja, apropriaram-se das terras públicas dos cerrados, pagando por elas preços quase irrisórios, posteriormente repassaram-nas para outros investidores/especuladores que desembarcaram em terras piauienses nos anos 1990 (Alves, 2000). Algumas delas continuam bastante presentes nessa região, atuando em negócios diversos, dentre outros também na venda de terras.

O avanço privado em terras devolutas do sul do Maranhão, muitas habitadas por posseiros, e a especulação que cresce em função de um comércio fundiário cada vez mais lucrativo produzem, nos últimos anos, várias modalidades de violência praticadas pelos velhos e pelos novos latifundiários contra um número crescente de famílias camponesas. Dentre outras evidências, verifica-se um aumento dos conflitos pela posse da terra na região (tabela 07), revelando que a expansão da agropecuária moderna nos cerrados maranhenses não resulta apenas na geração de algumas ocupações, mas ela produz exclusão, principalmente porque retira daquela população seus meios de vida localizados nas áreas que hoje são de interesse desse capital. As formas de reação dos camponeses que perderam suas terras passam pelo enfrentamento direto com os representantes do capital agropecuário.

\begin{tabular}{|c|c|c|c|c|}
\hline \multicolumn{5}{|c|}{ Tabela 07 - Conflitos de terra no Estado do Maranhão e na mesorregião } \\
sul maranhense 1997 - 2003
\end{tabular}

Fonte: Comissão Pastoral da Terra (CPT), 1997-2003. 
A movimentação de capital ocorrida nos últimos anos no sul do Maranhão não reflete em mudanças nas estruturas de desigualdades sociais da região; pelo contrário, acentuam-se as contradições na medida em que se expandem velhas modalidades de tensões ao mesmo tempo em que outras aparecem.

O município de Balsas, por exemplo, teve uma expansão da periferia pobre, emergindo ali problemas muito semelhantes aos verificados no novo urbano do oeste baiano. A cidade cresce de forma desordenada, motivada pelo fluxo de população que deixou de habitar as áreas rurais, seja porque foi expulsa pelo capital agropecuário ou porque ela própria cria, no seu imaginário, a ilusão de que no urbano haverá alguma ocupação. É significativo o número de jovens que abandonam suas moradias nos povoados e migram para a cidade de Balsas, deixando seus familiares mais velhos cuidando da unidade camponesa. Essa, por conseguinte, desarticula-se pela falta de braços para levar adiante o trabalho nas pequenas roças. A imagem produzida de Balsas gera expectativas também na população de outros municípios e até de outros estados nordestinos, sobretudo do Piauí. A expectativa criada pelos migrantes a respeito de um urbano pretensamente próspero se dissipa rapidamente quando percebem que as riquezas produzidas se canalizam para o seleto grupo dos representantes do agronegócio. Aos novos pobres que chegam ao urbano, juntam-se também os antigos, e a ambos restam-lhes as sobras de um crescimento econômico concentrado e concentrador. A urbanização de Balsas traz, assim, uma importante revelação de que a modernização é um processo que se organiza pela seleção dos espaços e das pessoas, em um constante movimento de não-simultaneidade gerador de crise.

Contribuiu também para o crescimento demográfico de Balsas a chegada dos grupos de empreendedores sulistas, alguns deles, deslocandose diretamente para o trabalho na agricultura, com sua residência sendo construída na própria fazenda. Outros residem no urbano e se dedicam a algum tipo de comércio ou serviços voltados para a agricultura. O fluxo de migrantes em direção ao urbano de Balsas produziu uma mescla de pessoas de diferentes origens e distintas condições sociais e um substancial aumento 
da circulação de veículos produzindo uma sensação de caos urbano ${ }^{48}$ devido ao movimento intenso de pessoas, automóveis, camionetes, caminhões, motocicletas e bicicletas por ruas que ainda não estão adaptadas para o ritmo que desencadeou a modernização, como nos esclarece os depoimentos abaixo:

"Balsas ainda está no período de pioneirismo e intermediação. Ela ainda não se encontra definida, não é uma cidade nem sulista nem mais uma cidade nordestina. A prefeitura ainda não enxergou o crescimento demográfico pela qual a cidade passou. Uma cidade que se inchou; quando se sai ali na rua ao meio dia se vê bicicleta atropelando bicicleta, moto atropelando bicicleta, carro atropelando moto e bicicleta; ciclista se jogando na frente, é um verdadeiro caos, não é uma cidade planejada, não tem ciclovia, porque a maior parte da população anda de bicicleta, as ruas do centro são estreitas, incapazes de atender ao novo ritmo da cidade, quando chove alaga tudo e a luz acaba (...)"

(Gisela Introvini, superintendente da Fapcen. Entrevista concedida em janeiro de 2006).

"Balsas foi uma das cidades que mais cresceu no Brasil. Isso fez crescer o mercado informal e a violência por conta do inchaço. Isso porque quando um corpo incha é porque tá enfermo. Cresceu mas não se desenvolveu, há um crescimento econômico muito grande na região, mas não há um desenvolvimento econômico, porque a maior parte da população não está participando desse crescimento"

(Erivaldo Alves Fonseca, sub-secretário da agricultura do município de Balsas. Entrevista concedida em janeiro de 2006).

A aceleração com que o espaço da cidade se transforma é visível aos olhos de qualquer pessoa. O Plano Diretor urbano do município tornou-se obsoleto em pouco tempo e não atende mais às necessidades da nova urbanização. Áreas que há menos de vinte anos se localizavam na borda da cidade atualmente se transformam em centrais, pois o espalhamento urbano avança com expressiva velocidade (foto 09). A cidade ganha novas formas, o velho estilo urbano de ruas estreitas e casas cujas fachadas defrontam-se com a rua, separadas apenas por uma calçada, indicando uma maior sociabilidade no passado, é substituído pelo das ruas largas com prédios

\footnotetext{
${ }^{48}$ Isso não quer dizer que esse urbano se reproduza de forma aleatória sem a manifestação de um movimento do capital orquestrado conduzindo aquela organização. Concordamos com Seabra (2004: 185), quando afirma que está inserida nesse aparente caos uma "convergência de diferentes lógicas que, todavia, são contraditórias entre si".
} 
comerciais. Nos novos bairros proliferam as casas muradas, nelas os seus moradores abdicam do contato com o vizinho pelo consumo das mercadorias (aparelhos eletrônicos de última geração, por exemplo). Apenas algumas áreas da cidade, existentes anteriormente, são aproveitadas adaptando-nas às novas funcionalidades. $O$ que ganha importância nesse cenário são os bancos com suas agências com departamentos especializados para atender os representantes do agronegócio; os grandes supermercados que dividem espaços com as lojas de magazines, ao estilo dos shopping-centers das metrópoles; as lojas de máquinas agrícolas e de carros modernos; os postos de combustíveis movimentados pelos fluxos de caminhões. Enfim, Balsas está repleta de conteúdos da modernidade, mesmo tendo se inserido nela plenamente há apenas alguns anos.

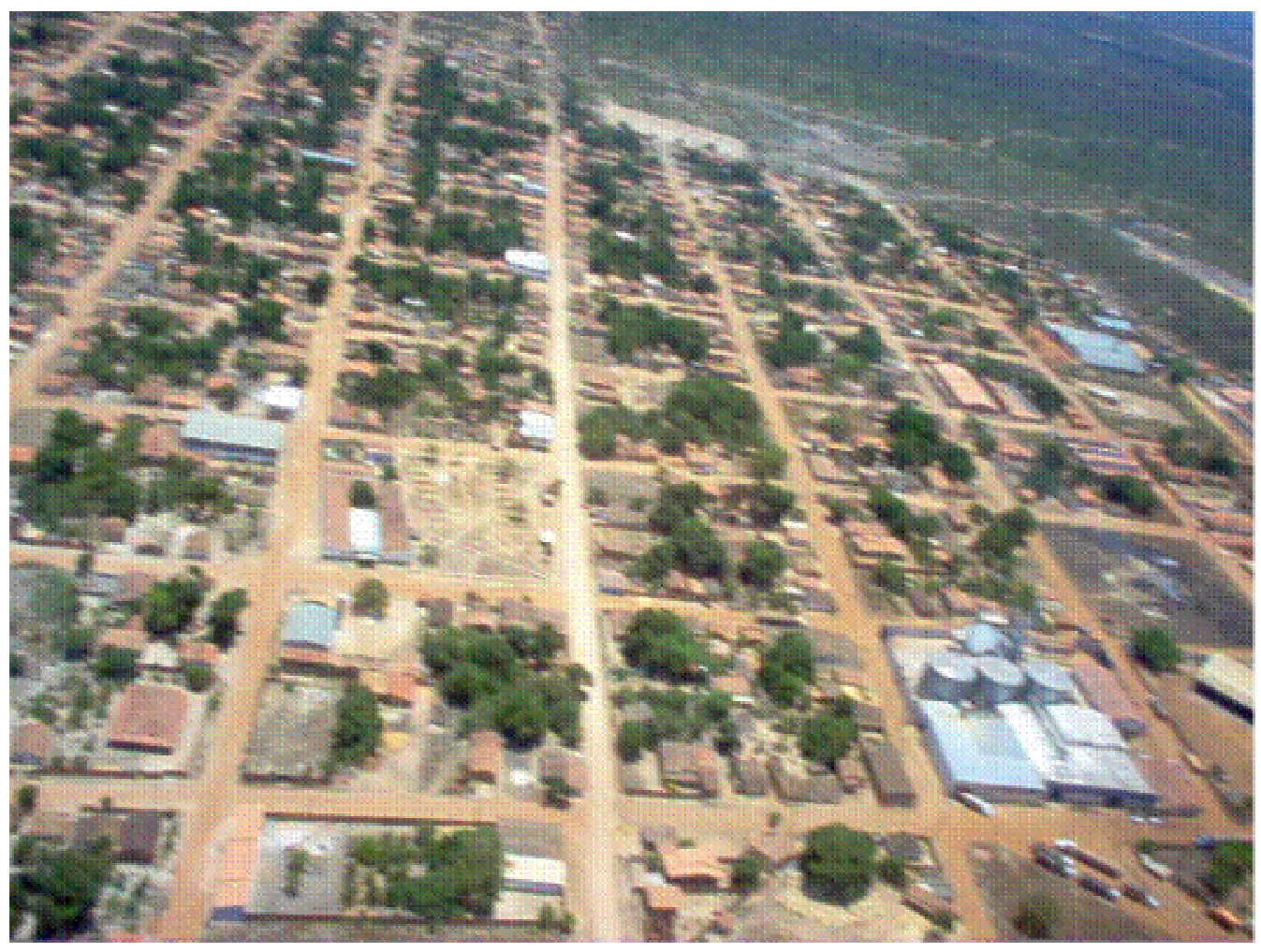

Foto 09 - Vista panorâmica de um dos novos bairros de Balsas. Ibama, 2005.

Se as velhas formas espaciais são adaptadas ou desaparecem pela insurgência do novo, a vida cotidiana também se adapta aos novos tempos, assimilando as manifestações dos grupos sociais que se instalam, 
particularmente os sulistas. As marcas dessa cultura, sobretudo a gaúcha, territorializaram-se não somente nos hábitos alimentares, mas em outras manifestações no novo contexto urbano de Balsas. A semana Farropilha é uma delas. Realizada pelo CTG local, no mês de setembro, o evento possui uma programação que inclui vestimentas características, comidas e músicas típicas. A festa conta com a participação de um grande número de migrantes sulistas, inclusive de outros municípios da região ou de outros estados da fronteira agrícola e mesmo da região Sul do Brasil. Poucos nordestinos participam, entretanto, do evento, o que demonstra um distanciamento que ainda impera entre os grupos.

Apesar do processo de aceleração da modernização se apropriar do tempo das pessoas dando-lhe outro sentido, do distanciamento do agrário e imposição dos hábitos da vida urbana, que rapidamente se difunde separando a festa da vida, nota-se que ainda persistem certas tradições da cultura local. É um espaço que sofre cada vez mais a influência do meio agrícola moderno, mas ainda está impregnado pelos valores da sociedade agrária, principalmente pela presença de pessoas que até há pouco tempo eram camponesas. Estes passam a viver na cidade, mas carregam consigo determinadas manifestações do antigo campo, dentre outros o sentido da festa e todos os seus simbolismos. Os festejos de Santo Antônio, padroeiro da cidade, acontecem no mês de junho e representam o momento do resgate das tradições marcadas pelo vivido em momentos passados e que ainda atribui sentido em tempos atuais, mesmo que enviesado pelo mundo da mercadoria, pois também a cultura popular vira espetáculo. Além da manifestação religiosa que está presente na festa e corresponde ao sagrado, nos dias do evento são realizadas também vaquejadas e a missa do vaqueiro. Estas últimas demarcam um tempo em que a economia e a vida da população local eram conduzidas pela pecuária, atividade responsável pela primeira ocupação da região e que perdeu força diante do avanço da agricultura moderna. Ficaram, no entanto, as marcas desse passado.

Bem como o que já vimos para o caso de Luis Eduardo Magalhães, o repentino crescimento urbano de Balsas se reflete também na valorização da terra urbana, fato que exclui uma parcela importante da população do direito à moradia, ao mesmo tempo em que se forma uma cidade segregada ou que se 
auto-segrega. Encontram-se instalados na cidade bairros de população mais abastada vivendo em condomínios fechados, como o "Jardim do Sol", habitado por ricos comerciantes, gerentes, médicos, fazendeiros (foto 10). Do outro, população vivendo em casas miseráveis instaladas em ruas quase intransitáveis nos dias de chuvas e empoeiradas na estiagem, construídas às pressas para abrigar os novos habitantes; são eles antigos posseiros que se transformaram em trabalhadores temporários nas fazendas de soja (foto 11). O bairro de São Felix, na periferia de Balsas, exemplifica os elementos de tal descrição. Até recentemente era uma fazenda que virou área urbana por conta do rápido avanço da cidade sobre o rural. Este bairro - cujas terras estão sob disputa judicial entre o fazendeiro e os novos moradores - é fruto de uma ocupação organizada através de movimentos populares conduzidos por pessoas excluídas do direito de morar. O bairro de São Felix se manifesta também como um símbolo da maneira contraditória pela qual avança a modernização contemporânea no sul do Maranhão. Balsas converte-se, nesse sentido, em um município que apesar de possuir um pouco mais de 70 mil habitantes (segundo estimativas do IBGE) já se depara com os mesmos problemas vividos pelos grandes centros urbanos, como os de produzir população excluída do direito de morar, necessitando, assim, de se ingressar em movimentos que lutam por esse direito. Até há pouco tempo essas situações eram raras de acontecer nos cerrados nordestinos, hoje representam a regra no urbano que surge.

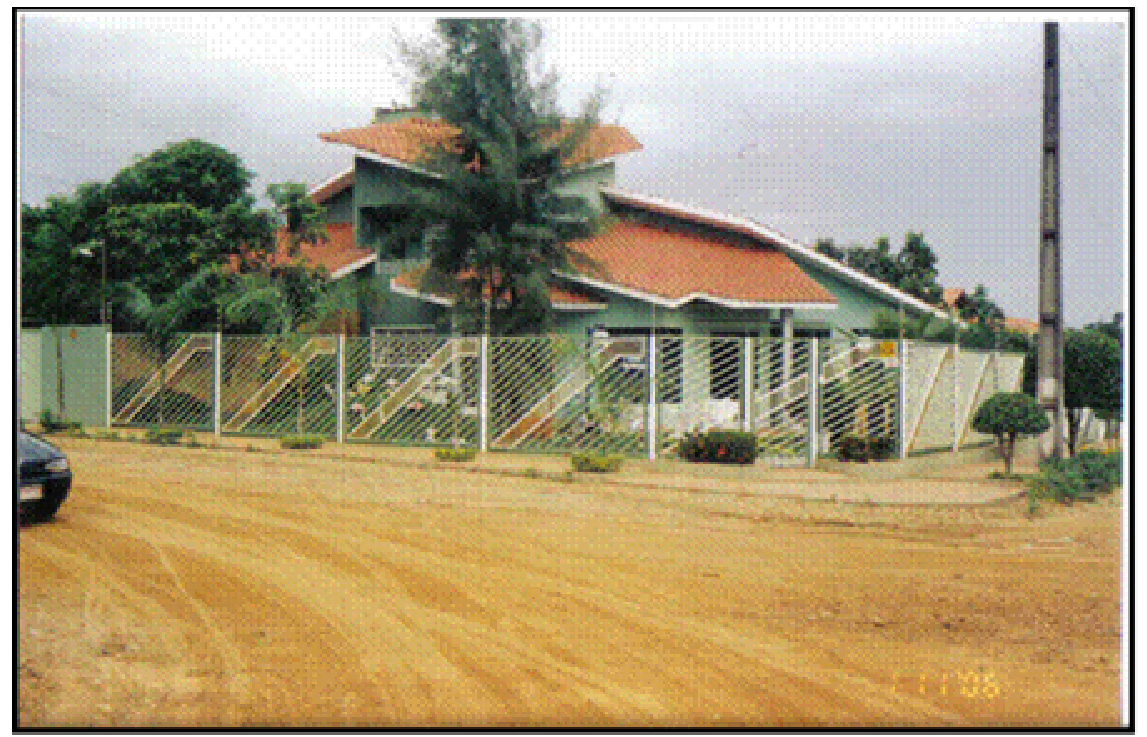

Foto 10 - Casa do condominio Jardim do Sol em Balsas. Foto do autor, janeiro de 2006. 


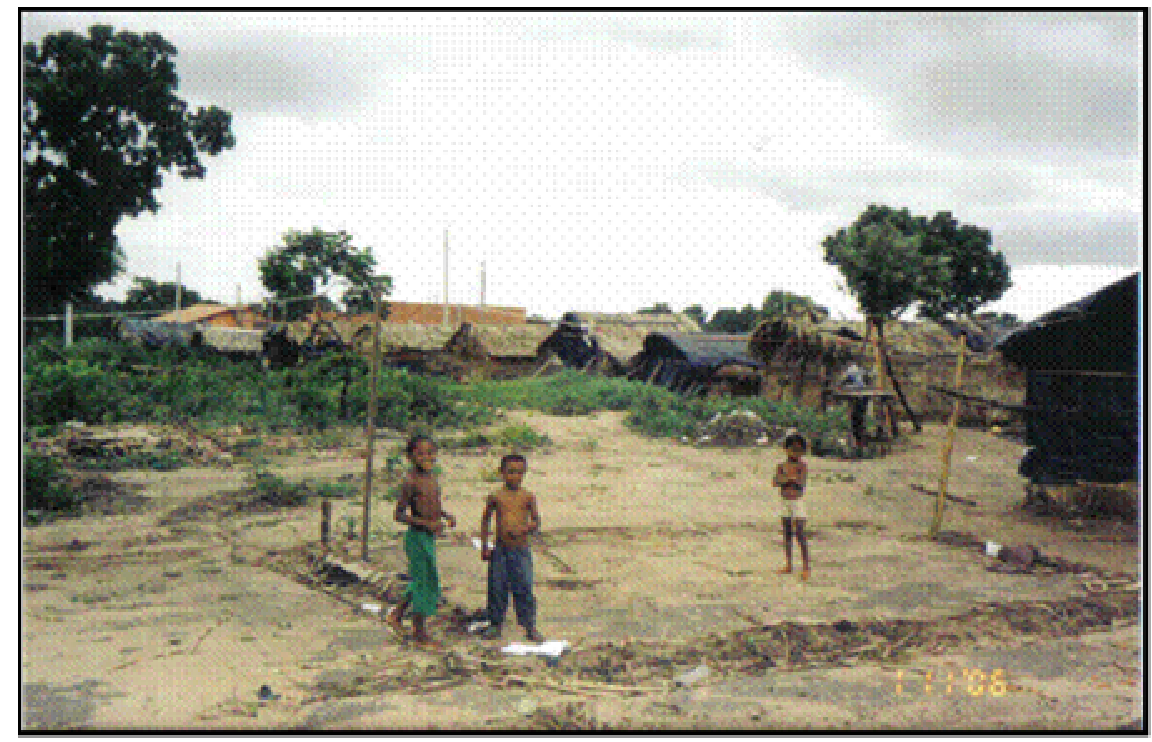

Foto 11 - Bairro de Sabo Felix na periferia de Balsas. Foto do autor, janeiro de 2006 .

Os indicadores de pobreza do município, do mesmo modo, continuam apresentando poucas alterações. O Índice de Desenvolvimento Humano (IDHM) do município é de 0,696 , pouco acima da média do estado $(0,636)$, e abaixo do restante do país $(0,766)$. A porcentagem de crianças de 07 a 14 anos analfabetas no município é de $22,2 \%$, enquanto a média brasileira para esse mesmo segmento de população é de $12,4 \%$. Dos jovens de 15 a 17 anos, 24,77\% estão fora da escola, enquanto que para as crianças de 10 a 14 anos esse índice é de 7,06\% (BASA/IPEA/ANPEC, 2002). Outros indicadores sociais apontam nessa mesma direção, demonstrando que a produção de riqueza advinda da modernização agropecuária não reflete sobre a população mais carente dessas regiões. $O$ trabalho precarizado é um outro fenômeno que passa a ocorrer com mais freqüência no sul do Maranhão, em muitos casos ele está associado diretamente às fazendas de agricultura moderna.

Acrescenta-se ao quadro de mudanças descrito o fato de que o avanço da agricultura moderna tem um efeito devastador sobre o ambiente natural, haja vista que produz a aceleração do desmatamento (foto 12), o envenenamento e o assoreamento dos cursos d'água, eliminando os principais meios de vida mantidos pela população camponesa local. O rio Balsas e seus afluentes sofrem com o assoreamento motivado pela abertura 
de áreas para a produção de soja, que vão inclusive avançando sobre as matas ciliares, reduzindo abruptamente o volume de água ou mesmo fazendo desaparecer alguns cursos. O problema é detectado nos platôs onde estão as nascentes dos principais rios que, com a eliminação da vegetação nativa, reduz-se significativamente o regime de alimentação hídrica dos mananciais. Ocorre também nos baixões, cujos rios e brejos estão secando, devido ao acúmulo de sedimentos transportados desde os platôs por conta das terras desnudadas. Proliferam também os casos de contaminação dos espaços de vida dessa população, sobretudo pelo uso indiscriminado de agrotóxicos das lavouras nas serras. Cita-se aqui os inúmeros povoados, como os de Boa Esperança, Vão das Salinas, Baixa Funda, dentre outros. Todos eles estão desaparecendo após a instalação do agronegócio na região. Esses fatores colocam em evidência as formas de colapso de uma sociedade em que o mercado passa a mediar todas as relações da vida.

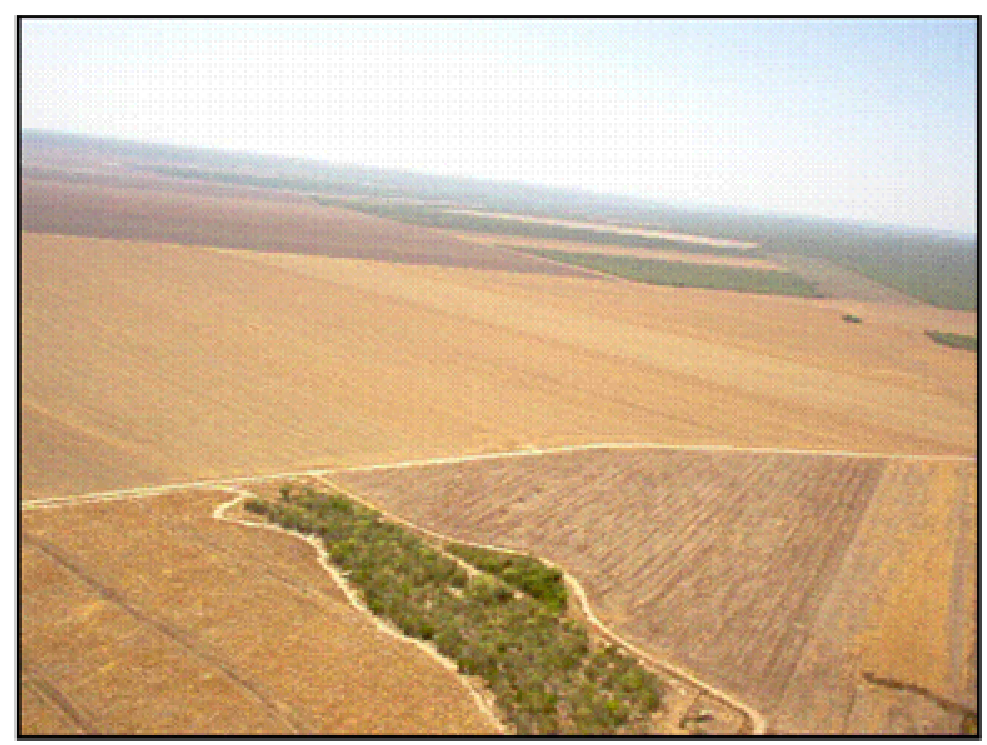

Fotos 12 - Area sendo preparada para o plantio de soja nos gerais de Balsas. Ibama, 2005. 


\section{3 - A CORRENTE MIGRATÓRIA SULISTA E A OCUPAÇÃO DOS CERRADOS PIAUIENSES}

\section{1 - A mobilização do trabalho no Brasil: algumas considerações}

O território brasileiro se formou a partir da migração de nacionais e de estrangeiros desde os anos de sua formação num processo contínuo de ocupação e re-ocupação de áreas. Dos primeiros portugueses ${ }^{49}$ que desembarcaram nessas terras até os nossos dias, uma das características que define a construção da sociedade brasileira é o fato dela ter sido constituída por diferentes grupos étnicos que se deslocaram para esse país, servindo de mão-de-obra e estoque de mão-de-obra às sucessivas etapas do processo de modernização capitalista. Essa modernização passada, no entanto, que teve como um dos seus pilares a disponibilidade de força de trabalho aproveitada ou em reserva, já não se efetiva plenamente no nosso atual período histórico, na medida em que a massa marginal de hoje não encontra mais os meios para empregar-se, portanto, está em disponibilidade, mas não se consumam mais as alternativas para tornar-se explorada. Isso evidencia, nesse sentido, o caráter de colapso do atual estágio da modernização.

O fato de uma mercadoria ser elevada à condição de protagonista em determinado momento histórico ou desaparecer em outro se dá pela lógica global de formação do sistema produtor de mercadorias, da qual o Brasil, assim como os demais países colonizados, tornaram-se alicerces para o processo de acumulação primitiva capitalista.

A dinâmica migratória da população brasileira esteve condicionada, seja no período colonial ou no pós-independência, pela escolha de novas áreas para a produção de mercadorias, atendendo ao sentido determinado pela demanda do mercado externo (Prado Jr., 1965). Assim, ao mesmo tempo em que o capital elege uma área para tornar-se o centro de produção de determinada mercadoria, elege também o grupo social e o coloca em movimento não importando onde ele esteja, escolhendo aquele que poderá

\footnotetext{
${ }^{49}$ Não estamos considerando os portugueses como migrantes estrangeiros, visto que o Brasil colônia era território luso.
} 
concretizar melhor o projeto do capital. O sujeito é mobilizado ou se mobiliza quando ele internaliza as exigências de valorização do capital, em ambos os casos, entretanto, resulta numa mobilização forçada. Essa perspectiva parece-nos mais adequada para entender a lógica que comanda os movimentos migratórios populacionais. Descarta-se, assim, a adoção do enfoque escolhido pelos chamados economistas neoclássicos, segundo os quais a migração resulta de atos de vontade dos indivíduos, na medida em que, acreditam, possuem autonomia para se colocar em movimento (Salim,1992). O deslocamento espacial dos indivíduos, nessa corrente interpretativa, assenta-se numa decisão pessoal e não nas forças econômicas produtoras da mobilidade. Ou seja, o trabalhador, ao optar pretensamente por outra área de moradia, faz antes um balanço dos ganhos e das perdas de seu deslocamento; a decisão de partir passa também, em certa medida, pelo crivo da subjetividade do migrante (Becker, 1997).

A intenção aqui é olhar a migração de uma outra perspectiva, qual seja, a do trabalho. Este, ao nosso ver, é o elemento central da discussão migratória, na medida em que representa um lado do tripé da acumulação capitalista (Marx, 1968 [1894]). Para dispor do trabalho, o capital define as estratégias e aciona os mecanismos necessários para sua mobilização. $\mathrm{O}$ trabalhador, por outro lado, coloca-se à disposição do capital e se vê forçado a migrar, pois a única mercadoria que possui é a si próprio; vende, então, seus atributos pessoais para se manter vivo. Sujeita-se, em última análise, à ação do capital (Becker, 1997). Ou seja, é necessário que os homens disponibilizem sua força de trabalho e tornem-na móvel para poder acompanhar o movimento do capital (Gaudemar, 1977). Nesse sentido, ao recorrer ao deslocamento, o migrante busca, sobretudo, garantir que haja a possibilidade de vender sua mercadoria, a força de trabalho, em outro lugar. Ao fazer isso, o migrante não faz simplesmente um cálculo individual de ganhos que possam existir em sua mobilidade espacial, mas está sendo forçado a participar do processo migratório para poder manter a sobrevivência sua e da família. Igualmente porque o capital está exercendo sobre ele uma pressão para colocá-lo em movimento, como nos esclarece Gaudemar (1977: 17): 
"Com a 'mobilidade' do trabalho manifesta-se sempre o modo como os homens submetem o seu comportamento às exigências do crescimento capitalista. Toda estratégia capitalista de mobilidade é igualmente estratégia de mobilidade forçada. O discurso econômico serve de verniz para demonstrar, quer a inevitabilidade do fenômeno, quer à existência de vantagens individuais ou coletivas que teoricamente ele deve apresentar".

Exceto a situação dos negros escravizados, os distintos grupos sociais colocados em movimento no Brasil resultam dessa lógica. Formaram-se, ao longo desses cinco séculos, correntes migratórias específicas que adquiriram importância num dado momento da história econômica do país, por serem requisitadas de acordo com suas características sócio-demográficas para tornar possível a reprodução ampliada do capital.

A questão migratória brasileira do século $\mathrm{XX}$, assim como em outros períodos, é ilustrativa de como o capital lança suas estratégias para colocar em movimento grupos sociais determinados. Apesar de sua complexidade e das diversas trajetórias envolvendo um volume considerável de pessoas de todos os lugares do país, dois grupos regionais ganham importância nos movimentos migratórios da população brasileira, constituindo-se duas correntes com grande destaque no cenário nacional, quais sejam: a nordestina e a sulista.

Os nordestinos representam uma corrente migratória relevante, com várias ramificações pelo território brasileiro. Essa corrente inicia-se com a decadência da cana-de-açúcar como mercadoria protagonista de transferência de riqueza para Portugal, em meados do século XVIII. O fim dessa etapa da modernização do Nordeste brasileiro fortalece o movimento populacional para fora de seus limites regionais. Mas, foi no século XX que a força de trabalho nordestina torna-se fundamental para a economia do Sudeste, sobretudo de São Paulo. Desde 1920, o governo paulista reordenou paulatinamente sua política de atração de força de trabalho, visando substituir, nas lavouras de café, os trabalhadores estrangeiros pelos nacionais. A condução dessa política contou com ampla participação do Estado brasileiro, que foi o responsável pela elaboração de leis dificultando a entrada de estrangeiros no país e, ao mesmo tempo, lançando mecanismos que possibilitassem a transferência de trabalhadores, predominantemente nordestinos e mineiros, para São Paulo (Paiva, 2000). São esses migrantes que, a partir de então, se 
tornarão referências dos grupos econômicos, inicialmente dos cafeicultores e, posteriormente, dos industriais do Sudeste. Se a corrente nordestina direcionou-se, principalmente a partir da década de 1930, para o Sudeste e, posteriormente também para o Centro-Oeste e áreas da Amazônia, ou seja, seguindo uma orientação mais para o "sul"; a sulista, também de grande relevância no cenário migratório brasileiro, toma um sentido inverso seguindo mais para o "norte" (mapa 10). Enquanto a primeira direciona-se para o rural e para o urbano, a segunda apresenta um perfil mais rural, embora com implicações diretamente no urbano, pois na trajetória do grupo que acompanha a expansão da agricultura capitalista moderna deslancha uma urbanização crescente. A corrente migratória sulista foi uma das principais responsáveis pela expansão da agricultura moderna no campo brasileiro nas últimas décadas. Atualmente, essa corrente se difunde velozmente nos cerrados nordestinos respondendo por uma nova dinâmica espacial urbana e agrícola naquela região. 
Mapa 10: Migração dos Colonos Gaúchos na Região Sul do Brasil

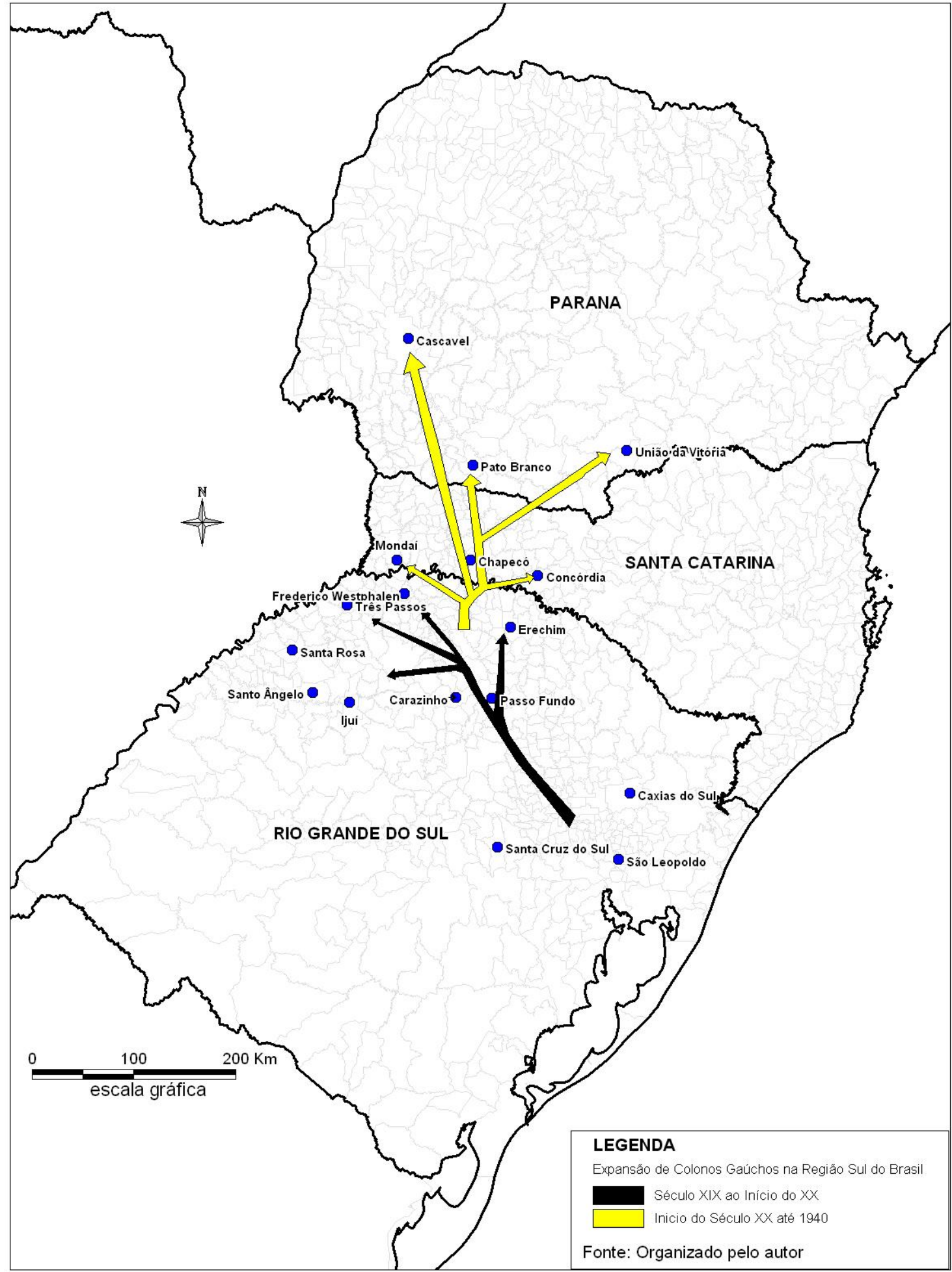

Elaboração: Geogr. Rinaldo Gomes Pinho e Vicente Eudes Lemos Alves 
Identificar um fluxo migratório que se direciona para uma área do interior do Nordeste parece, à primeira vista, contraditório, na medida em que tradicionalmente a região se inseriu no contexto de modernização brasileira como fornecedora de força de trabalho para outros centros econômicos do país. Esse fato não se alterou com o florescer de uma nova conjuntura econômica local; continua do mesmo modo gerando levas de migrantes para outras regiões, trabalhadores em busca de ocupação onde ainda se vislumbra que ela possa existir; muitas vezes isso se constitui apenas num ato iludido, devido a sua implosão no mundo moderno (Grupo Krisis, 2003). A diferença que ocorre atualmente nos cerrados nordestinos, quando se compara ao seu passado recente, é o fato de agora tornar-se também um espaço que recebe migrantes. Ou seja, os cerrados nordestinos configuram-se, a um só tempo, receptor de força de trabalho de outras regiões e fornecedor de força de trabalho para fora dos limites regionais, confirmando que a modernização é sempre um processo permanente de descontinuidade.

Tal situação nos coloca diante da necessidade de buscar paradigmas que nos dêem conta de entender o fenômeno migratório na sociedade capitalista contemporânea, a qual se move cada vez mais pela crise do trabalho (vivo). Adotar aquela visão dicotômica de que a migração se mede pelo balanço entre espaços que ganham e os que perdem população não dá mais conta de explicar esse fenômeno atualmente, se é que em algum momento foi possível explicar a migração da moderna sociedade produtora de mercadorias considerando apenas esse modelo interpretativo. No processo de formação do capital, os espaços se metamorfoseiam constantemente, de acordo com as necessidades de cada momento histórico, para que aconteça a reprodução do sistema. Segundo Gaudemar (1977: 13), "Desde os inícios do capitalismo, o capital tende a subjugar todas as esferas que podem contribuir para a sua valorização e, portanto, destruir todas as esferas concorrentes, a monopolizar toda a esfera produtora ou realizadora de mercadoria".

O direcionamento das forças produtivas obedecerá, nesse sentido, à orientação dada pelo capital. Pensar, portanto, a formação do território brasileiro para o capital, seja do passado ou do presente, requer debruçarmos sobre a questão da mobilização do trabalho, pois é necessário que os homens disponibilizem sua força de trabalho e sejam móveis para seguirem o movimento da reprodução capitalista (Gaudemar, 1977). 
A tentativa, nesse capítulo, será a de compreender a corrente migratória sulista como fazendo parte das estratégias do capital de tornar os grupos sociais móveis para ampliar o processo de acumulação. Para tanto, pretende-se fazer um breve percurso histórico de tal mobilidade e a maneira pela qual a presença desse grupo no Piauí resulta na formação de uma nova dinâmica econômica, social e espacial naquele estado, particularmente na região dos cerrados.

\section{2 - A corrente sulista: do núcleo irradiador à sua expansão pelo território brasileiro}

A corrente sulista ou "gaúcha" - como é predominante reconhecida - possui ramificações em quase todo o território nacional, principalmente acompanhando a expansão das áreas de produção agrícola do Brasil, mas também para além de nossas fronteiras políticas, adentrando em países vizinhos como Paraguai, Uruguai, Bolívia e Argentina (Haesbaert, 1998; Oliveira \& Barcelos, 1999). Em tais países, a presença de população sulista caracteriza-se também pela sua dedicação às atividades agrícolas, freqüentemente associadas a lavouras modernas de soja.

Destacam-se, nessa corrente, fortes manifestações étnico-culturais que permanecem como identidade na trajetória do grupo e que são, deliberadamente, difundidas, dentre outras: a ideologia da positivação do trabalho, advinda da cultura européia trazida pelos primeiros imigrantes; o pioneirismo na ocupação dos cerrados para o desenvolvimento da agricultura capitalista moderna; os hábitos alimentares originários principalmente no Rio Grande do sul, como o chimarrão e o churrasco; as instalações dos Centros de Tradições Gaúchas (CTGs) nas áreas onde o grupo se fixa. Tais manifestações são reveladoras das preocupações em preservar e difundir as identidades da região Sul do Brasil, especialmente no que diz respeito à "re-territorialização" das tradições gaúchas. (Haesbaert, 1997).

Os precursores dessa corrente são os imigrantes que desembarcam no Brasil nos seus primeiros anos pós-independência, liderados pelos alemães que, em 1824, fundaram a colônia de São Leopoldo, no Rio Grande do Sul. Direcionada pelo recém-constituído Estado brasileiro para ocupar terras do Sul, a colonização visava não somente garantir a manutenção do território nacional, mas também arregimentar grupos humanos para a execução do projeto de produção de gêneros agrícolas destinado ao abastecimento do mercado interno, haja vista que partes 
daquelas terras, da Campanha Gaúcha, eram aproveitadas para as atividades pastoris cujo interesse maior recaía sobre os lusos brasileiros. Nos arredores dessas zonas de campos, em terras de florestas e serras, foram assentados os primeiros imigrantes, sobretudo, os teutos e os italianos.

O projeto de colonização baseou-se na pequena propriedade fundiária ocupada por imigrantes agricultores que já possuíam essa condição desde seus países de origem, na Europa. Mesmo os que não eram, converteram-se em lavradores no Brasil por imposição do Estado nacional, permanecendo nesse ramo também as gerações posteriores. Ao estudar a colonização alemã no Rio Grande do Sul, Roche (1969: 243), ressalta a importância dos imigrantes teutos para o desenvolvimento da agricultura gaúcha, como fica claro em suas palavras:

"Com efeito, é à colonização alemã que o Rio Grande do Sul deve o ressurgimento de sua agricultura. Os imigrantes alemães e seus descendentes, dos quais nove décimos ainda são agricultores, corresponderam largamente ao desejo e à esperança da administração brasileira, que encorajara sua imigração para povoar as zonas até então abandonadas pelos luso-brasileiros, e para explorá-las, desbravando-as e cultivando-as depois. De sorte que, em 1885, um autor alemão pôde escrever a propósito do Rio Grande do Sul: 'a agricultura é exclusivamente nossa"'.

Acrescenta ainda:

"Se a legislação favorece a agricultura, o governo provincial envia, para as colônias que fundou, o maior número possível de imigrantes e faz deles agricultores, por bem ou por mal (...)" (p.103).

O fato de possuírem, em sua grande maioria, anteriormente uma forte ligação com a terra facilitou, sobremaneira, o cumprimento dos objetivos traçados para essa colonização. Além disso, pôde-se manter uma maior coesão entre os colonos povoadores, na medida em que eles puderam preservar, em solos brasileiros, certos costumes do mundo agrário europeu. Se, por um lado, os colonos lograram manter suas tradicionais técnicas no cultivo de alimentos, por outro, incorporaram, ao seu cotidiano, vários traços da cultura indígena, principalmente as práticas de uso da terra, tais como as queimadas, a rotação de terras e o aproveitamento de algumas plantas que já eram cultivadas no Brasil 
(milho, feijão preto, mandioca, batata-doce) e "até mesmo a ferramenta indígena, a cavadeira e o bastão de plantar" (Waibel, 1979: 246).

O pouco avanço, em terras brasileiras, dos métodos agrícolas trazidos da Europa e a incorporação de outros também rudimentares resultaram num rápido esgotamento do solo e, em conseqüência, tornou-se necessário avançar sobre novas áreas para continuar produzindo mercadorias agrícolas. Essa expansão freqüentemente ocorria sobre as matas virgens no planalto rio-grandense e, posteriormente, nos demais estados do Sul do Brasil. O uso de instrumentos agrícolas com pouca tecnologia ainda era bastante freqüente nas propriedades do Rio Grande do Sul ao longo de todo século XX, principalmente na sua primeira metade. Essa situação passa a se alterar apenas no pós-Segunda Guerra Mundial, quando acontecem as primeiras iniciativas de incorporação de equipamentos mais modernos, conforme relata Brum (1988: 56/59):

“(..) Os instrumentos de trabalho eram simples: foice e machado, para o desbravamento e derrubada do mato; enxada e arado de tração animal, para o preparo do solo e controle das ervas daninhas; máquina manual de plantar; foicinha de cortar trigo, arroz, etc.; máquina manual de matar formiga; carroça e outros veículos de tração animal, para o transporte, além de outros. As técnicas de preparação do solo, cultivo, colheita, etc. eram fruto da experiência e se transmitiam de uma geração para a seguinte, aperfeiçoadas lentamente. A sabedoria da vida e do trabalho tinham grande valor. As principais energias utilizadas eram oriundas diretamente da própria natureza: energia humana e animal, da água e do vento. (...) Após a Segunda Guerra Mundial foi se tornando cada vez mais sensível o declínio da agricultura tradicional. Essa queda progressiva manifestou-se primeiro nas áreas de ocupação mais antiga e avançou, com relativa rapidez, para as áreas de colonização mais recente".

Outro fator importante da migração do colono para novas terras diz respeito ao tamanho dos lotes concedidos pelo governo brasileiro, variando de 25 a 30 hectares, normalmente em relevo irregular, o que era considerado insuficiente para as características das famílias de imigrantes. Elas demandavam extensões maiores, tendo em vista que as técnicas adotadas limitavam o uso mais prolongado dos terrenos. Ademais, o acelerado crescimento populacional decorrente das altas taxas de natalidade nas famílias imigrantes provocava uma pressão por terra e, conseqüentemente, uma rápida divisão da propriedade da família. A expansão demográfica fazia desaparecer rapidamente as áreas ainda disponíveis para colonização. No término da década de 1940, por exemplo, registrava-se que nas 
colônias do Alto Jacuí e Alto Uruguai, no Rio Grande do Sul, não havia mais terras suficientes para absorver os contingentes populacionais, devido à elevada formação de novos cônjuges que demandavam terras livres (Roche, 1969).

Tais fatores produziam uma situação que se tornou comum nas regiões de colonização estrangeira no sul do Brasil, qual seja, poucos anos após a ocupação esgotava-se uma zona de povoamento, e logo se partia em direção a uma outra que pudesse abrigar as novas gerações de produtores agrícolas. Waibel (1979: 256/7), ao comentar o tamanho da propriedade concedida aos imigrantes colonos, manifestava seu descrédito com o sucesso de um tipo de colonização que se efetivava a partir do modelo de lotes pequenos, famílias numerosas e parcos recursos financeiros e que se valia do uso de sistemas agrícolas deficitários num relevo de topografia irregular. Nesse sentido, diz que:

"Por todo o sul do Brasil, o tamanho médio da propriedade de um colono da mata é de 25 a 30 hectares. É de surpreender como a maioria dos colonos e até agrônomos aceitam este tamanho, sem sequer duvidar da sua justificação e sua conveniência. Na minha opinião, uma propriedade de 25 a 30 hectares é excessivamente pequena para a aplicação do sistema de rotação de terras, especialmente em regiões montanhosas. O problema do tamanho adequado as propriedades é vital para qualquer projeto de colonização, e devia ser estudado cuidadosamente de todos os ângulos, antes de ser iniciada a colonização. Para a compreensão alemã minimale ackernahrung; refere-se ela à mínima quantidade de terra necessária para proporcionar a um agricultor e sua família um padrão econômico e cultural decente. O minimale ackernahrung depende principalmente de dois fatores: as características de terra e o sistema agrícola que o lavrador deverá aplicar".

A rápida divisão da propriedade - tornando inviável a absorção dos novos membros da família de colonos - teve como conseqüência imediata o avanço da fronteira agrícola sobre as terras devolutas gaúchas e, posteriormente, para os demais estados do Sul (mapa 10). Na medida em que elas também se esgotavam, surgiam novas modalidades de relações de produção, as quais asseguravam que parte da população pudesse permanecer em sua área de origem, como as relações de arrendamento. Esse sistema começa a se difundir pelas áreas de colonização, sobretudo nas mais antigas. De acordo com Roche (1969: 322): 
"Esperando, sem dúvida, o não fracionamento da propriedade, vemos surgir uma nova tendência, ainda tímida, mas clara, a do reagrupamento da exploração: os últimos censos revelam-nos que há menos estabelecimentos agrícolas que propriedades. Essa evolução, demasiado recente para ter modificado profundamente a estrutura agrária das colônias, é a conseqüência da contradição que existe entre o direito sucessório e o modo de exploração. O sistema de empréstimo por arrendamento começa a difundir-se, em correlação com o florescer das vilas rurais, onde se estabelecem os pequenos proprietários que já não podem viver em suas terras. Assim, modificam-se, sob nossos olhos, as relações 'tradicionais' da propriedade e da exploração".

No mesmo ritmo acelerado com que se desencadeava a ocupação de novas terras, seguia também a especulação imobiliária. O comércio de terras nas frentes de expansão dos estados do Sul do Brasil torna-se um negócio lucrativo para alguns colonos e para empresas privadas de colonização. A abertura de uma nova área significava para o colono uma garantia de possuir terra própria para morar e produzir, mas também para aplicar seus recursos financeiros. Adquirir um ou mais lotes representava, para os agricultores mobilizados, uma poupança segura, na medida em que, ao empregar as suas economias nesse tipo de investimento, tinhase a certeza de ganhos num futuro imediato, haja vista a rápida valorização da terra em curto intervalo de tempo. Essa lógica de ocupação produziu não somente um movimento de colonos em busca de novas áreas, mas a proliferação de lotes vazios esperando valorização, ou que serviria para acomodação posterior dos filhos crescidos. Roche (1969: 358/9) identificou com propriedade esse fenômeno na ocupação de terras de Santa Catarina e Paraná:

"Assim como se quisera ver na especulação praticada por certos colonos uma das causas das primeiras migrações internas, da mesma maneira foi ela denunciada desde o começo do êxodo do Rio Grande do Sul. Em 1919, julgava o governo que os colonos rio-grandenses compravam, em média, 2.000 lotes anuais no Estado de Santa Catarina, mas que o número dos que emigravam era bem menor: a maioria deles, segundo seu costume de empregar todos os haveres em terras, ter-se-ia, além disso, protegido contra o aviltamento do poder aquisitivo da moeda no primeiro após-guerra, comprando lotes de 25 hectares na intenção de revendê-los, depois, mais caro. Certamente o preço das terras se eleva, mas ao mesmo tempo crescia o número dos colonos rio-grandenses que emigravam para Santa Catarina e, posteriormente, para o Paraná. Por fim, essas aquisições perderam o caráter especulativo que podiam ter, servindo, muitas vezes, para estabelecer um ou dois filhos do comprador". 
Na década de 1940 e 1950 a expansão da pequena propriedade no Rio Grande do Sul ainda ocorria nas últimas terras devolutas existentes no alto Uruguai (Ruckert, 2003). Essas terras, porém, já não eram suficientes para atender ao elevado parcelamento da propriedade camponesa no estado. A crise nesse segmento se agravaria nos anos posteriores, principalmente com sua crescente subordinação à agroindústria que se expande rapidamente pelo Rio Grande do Sul eliminando as posses daqueles agricultores com menos terra, conforme nos esclarece Brum (1979: 96):

"A rápida valorização, aliada à perspectiva de maior garantia, maior volume de crédito e maior produção agrícola, torna a compra de terras um bom negócio para quem possui disponibilidade de recursos financeiros. A pressão é feita principalmente sobre os pequenos proprietários, em dificuldades ou impossibilitados de ingressar no processo de modernização".

A crise da pequena propriedade produziu, ao longo de todo o século passado, a migração de moradores das antigas colônias gaúchas visando ocupar novas áreas no oeste catarinense e sudoeste do Paraná, destacadamente as de produção agrícola, e logo continuou ocorrendo, num movimento contínuo rumo a outras terras mais ao norte, ultrapassando as fronteiras regionais. Nos anos de 1970, esse fluxo torna-se intensificado com os projetos de colonização dos governos militares, particularmente na Amazônia Legal ${ }^{50}$.

A escolha dos sulistas para a ocupação das terras a serem colonizadas, no que viria a ser a nova fronteira agrícola, não ocorreu de maneira aleatória, mas fazia parte da estratégia governamental desde o governo Vargas (1930-1945) quando orientou a migração de agricultores para as "colônias agrícolas nacionais" (Santos, 1993); continuou nos governos militares (1964-1985), dirigindo os fluxos populacionais para a ocupação das terras da Amazônia. A transferência de população sulista, particularmente nos governos militares, viabilizar-se-ia com a adoção de dois conjuntos de diretrizes articulados entre si: a) incorporação de novas terras em outras regiões, a serem ocupadas mantendo o sentido de produzir para o mercado externo; b) deliberação de situações que permitissem a

\footnotetext{
${ }^{50}$ Nos governos de Getúlio Vargas e Juscelino Kubitschek houve políticas de colonização, no entanto, foram os governos militares, sobretudo, nos anos 1970, que implementaram projetos mais ambiciosos nessa direção. In: SANTOS, J.V.T. dos. Matuchos: exclusão e luta - Do Sul para a Amazônia. Petrópolis: Vozes, 1993.
} 
concentração da propriedade da terra nas antigas áreas de ocupação, principalmente no noroeste do Rio Grande do Sul, para começar por lá o processo de modernização agropecuária.

Para tornar possível o primeiro conjunto de diretrizes era preciso destinar áreas do interior do Brasil para um novo uso capitalista. Foram escolhidas, então, áreas de cerrados e da floresta amazônica. Para abrir caminho à agricultura capitalista moderna nessas áreas era necessário legitimar o uso da violência contra aqueles (camponeses, indígenas) que dificultassem a realização da modernização. O segundo conjunto de diretrizes ocorreria com a reestruturação do espaço de produção da região Sul, para atender a uma nascente agricultura voltada diretamente para o mercado: ao invés de minifúndios decidiam-se por propriedades maiores que garantiriam a produção em larga escala. A agricultura de grãos, nesse sentido, ocupará vastas áreas onde antes existiam formas camponesas de produção. Acompanhando esse tipo de agricultura surgem novas manifestações no cotidiano social daquela população, sobretudo no Planalto Gaúcho. Novamente Brum (1988: 110), traz-nos uma importante visão desse fenômeno de expansão da agricultura moderna:

"O processo de modernização da agricultura rompeu com a relativa lentidão, o sossego e a vida pacata do mundo rural e introduziu o homem rural num ritmo muito mais dinâmico e febricitante, envolvendo-o com exigências maiores, mais amplas e absorventes. Do mundo restrito, limitado, da família, do povoado e do município teve que passar a inserir-se, rapidamente no agitado mundo dos negócios, a nível de país e mesmo no contexto internacional".

A substituição de formas com predomínio de pequenas propriedades para outras de médias e grandes somente se tornou possível pela imposição da violência. Ou seja, o agronegócio avança no Sul adotando métodos coercitivos contra os pequenos produtores agrícolas, inclusive se valendo do aparato militar estatal para coagir aqueles que insistissem em permanecer ou lutar pelo uso produtivo das terras onde moravam. Não é por acaso que um importante movimento de resistência camponesa se organizará no Rio Grande do Sul, particularmente na região de produção de grãos no noroeste do estado. Foi a área onde nasceu o Movimento dos Trabalhadores Rurais Sem-Terra (MST), nos anos 1980, e, duas décadas antes, o Movimento de Agricultores Sem-Terra (Master), demonstrando que, ao retirar as terras das mãos dos camponeses, a agricultura 
moderna produziria novos movimentos de resistências (lokoi, 1996). A transferência para outras regiões do Brasil, de parte desse contingente de trabalhadores sem ou com pouca terra, representaria a abertura do caminho para a sedimentação do agronegócio no Sul e também evitava que as tensões sociais naquela região tornassem ainda mais ameaçadora a manutenção do regime autoritário militar. Nesse sentido, tenta-se desmobilizar os nascentes movimentos de trabalhadores rurais, sobretudo do Rio Grande do Sul, oferecendo aos colonos terra na fronteira agrícola. É ilustrativo dessas intenções o projeto de colonização do Incra denominado "Lucas do Rio Verde", no norte do Mato Grosso, formado pelos colonos sem-terra participantes do acampamento Encruzilhada do Natalino, no município de Ronda Alta, RS (Oliveira, 2005).

\section{3 - As transferências de agricultores do Sul do Brasil para a nova fronteira agrícola}

Foram utilizados vários mecanismos cujos objetivos eram esvaziar as terras pertencentes a camponeses nos estados do Sul, especialmente no Rio Grande do Sul. Tinha-se como meta formar, a partir daquele estado, médias e grandes propriedades destinadas à prática da agricultura de mercado; ao mesmo tempo, arregimentar indivíduos para enviá-los a uma outra região distante da sua, espacial e culturalmente. Tentava-se solucionar, dessa forma, dois problemas: disponibilizar espaços para o crescimento da agricultura capitalista moderna no Sul e deslocar população para os espaços que se consideravam livres de homens, preferencialmente a Amazônia e os cerrados.

Para atingir os objetivos da transferência de população camponesa e de médios produtores sulistas possibilitando o acréscimo da produção de mercadorias agrícolas, houve importante participação do próprio Estado nacional atuando em sintonia com os grupos econômicos privados. Tais políticas visavam, dentre outros objetivos: estimular o pequeno produtor a vender sua propriedade ao vizinho - o lindeiro; oficializar um discurso voltado à população sulista com o intuito de convencê-la das vantagens de migrar para uma área de colonização $^{51}$; fundar

${ }^{51}$ Santos (1993: 69 a 88) aponta várias estratégias utilizadas para estimular a migração do sulista para a Amazônia, sobretudo a população do noroeste gaúcho. Foram criados, inclusive, veículos de comunicação que deveriam cumprir o papel de induzir o deslocamento da população. Esse é o 
cooperativas agrícolas para comandar o processo de transferência de colonos de uma região para outra; possibilitar, nas áreas de colonização, acesso a terras baratas, a créditos agrícolas bancários e a financiamentos facilitados para aquisição de lotes agrícolas e terrenos destinados às residências nas agrovilas. A execução do projeto de formação da fronteira agrícola acontece pela ação em conjunto do Estado e do capital, como nos afirma Oliveira (2005: 65) quando analisa o processo de colonização do norte do Mato Grosso:

"Nesse aspecto estrutural, o estado e o capital caminham juntos. Este, por meio da venda de terra aos camponeses nos seus projetos de colonização, além do lucro com a venda, foi formando os 'viveiros de mão-de-obra'. O estado ficou com a tarefa de conter as tensões sociais e fez dos projetos de colonização e dos assentamentos de reforma agrária 'válvulas de escape' das áreas de tensão social. Essa é a raiz histórica da 'marcha para oeste', da implantação dos projetos agropecuários, da colonização e da expansão do agronegócio na fronteira. Entretanto, contém uma característica específica: o corte monopolista do processo, quer dizer, o processo de ocupação recente traz novas formas de atuação. Não se está diante da lógica ditada pela disputa livre no mercado, há tão-somente a imposição dos monopólios. A mercadoria que comanda esse processo de ocupação é a propriedade privada da terra (...)".

Nesse projeto de transferência de sulistas para a fronteira agrícola, necessitava-se também legitimar um discurso que difundisse o tipo de agricultor que se queria para o país. Precisava-se escolher um grupo social e formar a partir dele uma representação de um novo produtor que pudesse congregar em torno de si a face da desejada agricultura capitalista moderna. O modelo de agricultor selecionado foi o do "colono sulista", pois ele melhor personificava o perfil procurado. Evocava-se, assim, nesse migrante a descendência européia; o pretenso espírito de pioneirismo do grupo, presente desde os primeiros colonos desembarcados no Brasil; e, ainda, a positividade do trabalho como parte do molde do migrante agricultor moderno. A construção de tal imagem foi importante para a difusão da proposta de aumento da produção agrícola para o mercado, na medida em que a ocupação das novas terras - com vistas à produção em larga escala para exportação - não poderia ocorrer com trabalhadores com forte enraizamento da

caso, por exemplo, da fundação, em 1970, da Rádio Municipal de Tenente Portela (RS) e do Jornal da Terra, publicado no mesmo município entre o início de 1971 e o final de 1972. Neles, segundo Santos, as mensagens compunham um conjunto de categorias que visavam identificar três temas principais: "a situação social na região de origem; a situação social na região de destino e os meios de realização do trajeto de uma situação de uma à outra região". 
cultura camponesa tradicional, associada à agricultura de subsistência e ao uso de técnicas agrícolas menos avançadas. Desejava-se um agricultor que transmitisse a idéia de moderno, sintonizado com as novas técnicas agrícolas, mesmo que apenas alguns deles portassem efetivamente condições ou experiências em lidar com maquinários modernos e com outras exigências da agricultura capitalista. Buscava-se, assim, uma homogeneização a partir da emancipação do indivíduo da condição de camponês ou pequeno produtor capitalista em um trabalhador rural essencialmente produtor de mercadorias para o capital.

A construção da representação do agricultor que se queria para conduzir a modernização contemporânea da agricultura brasileira é realçada por Santos (1993: 197), revelando-nos que:

"Entretanto, a seleção social e a seleção regional da clientela dos programas [de colonização] foram consolidadas por uma representação social particular. Trata-se da categoria do 'colono modelo': é o agricultor que, supostamente, tem mais instrução, mais acesso às modernas técnicas agrícolas, mais utilização de insumos agrícolas industrializados, mais recurso ao crédito agrícola e que devia ser associado a cooperativas e aceitar os conselhos dos técnicos agrícolas. Enfim, pequenos produtores tecnificados, cujas origens serão evocadas, isto é, descendentes de imigrantes europeus ou japoneses".

A concretização do projeto apontado acima se efetiva verdadeiramente com a seleção de uma ampla parcela de famílias de agricultores sulistas, em geral, sitiantes, mas também produtores médios praticantes da agricultura moderna em sua região de origem. Desse conjunto de agricultores sulistas mobilizados, a presença dos gaúchos se faz em maior número, por isso mesmo que, para o imaginário dos moradores das fronteiras agrícolas, "gaúcho" é sinônimo de agricultor capitalista modernizado. Tal representação nem sempre é condizente com a verdade, haja vista a ocorrência, nessas regiões, de agricultores de outros estados do Sul e do Sudeste fazendo parte desse processo. Nesse universo de migrantes sulistas encontram-se agricultores praticando pequenas lavouras com técnicas pouco avançadas ou trabalhando precariamente para os conterrâneos, os grandes e os médios produtores. O que caracteriza o perfil desses migrantes é o fato de o grupo ser predominantemente composto por descendentes dos colonos estrangeiros que se fixaram inicialmente no Rio Grande do Sul e de lá foram mobilizados para os que hoje podem ser considerados como novos espaços 
brasileiros de produção agrícola destinada ao mercado. Tais migrantes deixarão suas marcas nesses espaços cujas extensões cada dia se alargam em distintas direções, incorporando terras de todas as grandes regiões brasileiras. Constrói-se assim, a partir da migração sulista, uma nova face de aceleração da modernização do território brasileiro, motivando rápidas transformações no campo e nas cidades.

O espaço agrícola da fronteira que se visualiza atualmente é sintomático das grandes transformações tanto no que diz respeito ao aumento substancial, nas últimas décadas, do volume de produção agropecuária, quanto da introdução de complexos de alta tecnologia para obter uma maior eficiência nos resultados gerais da agricultura. Não se pode falar dessas mudanças, todavia, sem mencionar a contribuição do migrante sulista.

A corrente sulista compõe-se em sua essência de agricultores deslocados para praticar atividades agrícolas, seja dedicando-se diretamente à produção de mercadorias agrícolas, seja comercializando suportes para tal setor. Às vezes, o deslocamento ocorre diretamente de uma área rural para uma outra também rural, como aconteceu com os sitiantes sulistas que migraram para áreas da floresta amazônica ou dos cerrados, construindo suas moradias dentro da própria unidade de produção, em muitos casos, distante dos núcleos urbanos locais. Há, ainda, a migração de população vinda das cidades do Sul do Brasil que, nas regiões de destino, instalou-se em áreas essencialmente rurais, ocorrendo assim um fluxo urbano-rural. No seu contexto mais amplo, entretanto, não há nesse movimento a concretização de um processo de ruralização dessa população. O que se identifica, às vezes, é um deslocamento de pessoas de uma área de urbanização mais estruturada para outra com pouca ou nenhuma urbanização. Em um momento imediatamente posterior à instalação dos migrantes nos espaços de constituição da agricultura moderna, nos platôs, surge a germinação de uma urbanização que, em muitos casos, resulta em centros urbanos importantes, como se observa em Balsas e Luis Eduardo Magalhães e em muitos outros lugares, nos estados do CentroOeste brasileiro.

\section{4 - A presença dos sulistas nos cerrados piauienses}

O movimento contínuo da corrente sulista em direção ao "norte", ocupando novas áreas incorporadas à agricultura modernizada, já se encontra no núcleo de 
irradiação da outra corrente, a nordestina, que se desloca no sentido inverso, para o "sul". A expansão do deslocamento populacional sulista e sua chegada no Nordeste, particularmente na parte ocidental - nos cerrados do oeste baiano onde desembarcaram os primeiros grupos ainda na década de 1970, teve impacto importante sobre a modernização agrícola contemporânea dessa sub-região. Identifica-se, como vimos, nos cerrados nordestinos, nos últimos anos, um forte dinamismo econômico advindo da agricultura capitalista moderna, tanto da produção de grãos (sobretudo a soja) e de seus derivados, quanto do comércio de equipamentos e insumos agrícolas. Os migrantes sulistas são os responsáveis por introduzir as novas condições de produção nos cerrados nordestinos, na medida em que foram os precursores da agricultura produtivista naquela região.

A área mais recente de instalação de sulistas é a dos cerrados piauienses. Apesar dos primeiros grupos terem desembarcado naquele estado ainda nos anos 1980 (mapa 11), esse fluxo só ganha importância a partir de meados da década de 1990, mas ainda em menor expressividade do que os deslocamentos para os cerrados baianos e maranhenses (mapa 12). 
Mapa 11: Presença de Migrantes Sulistas no Brasil e em Países da América do Sul - 1950 a 2000

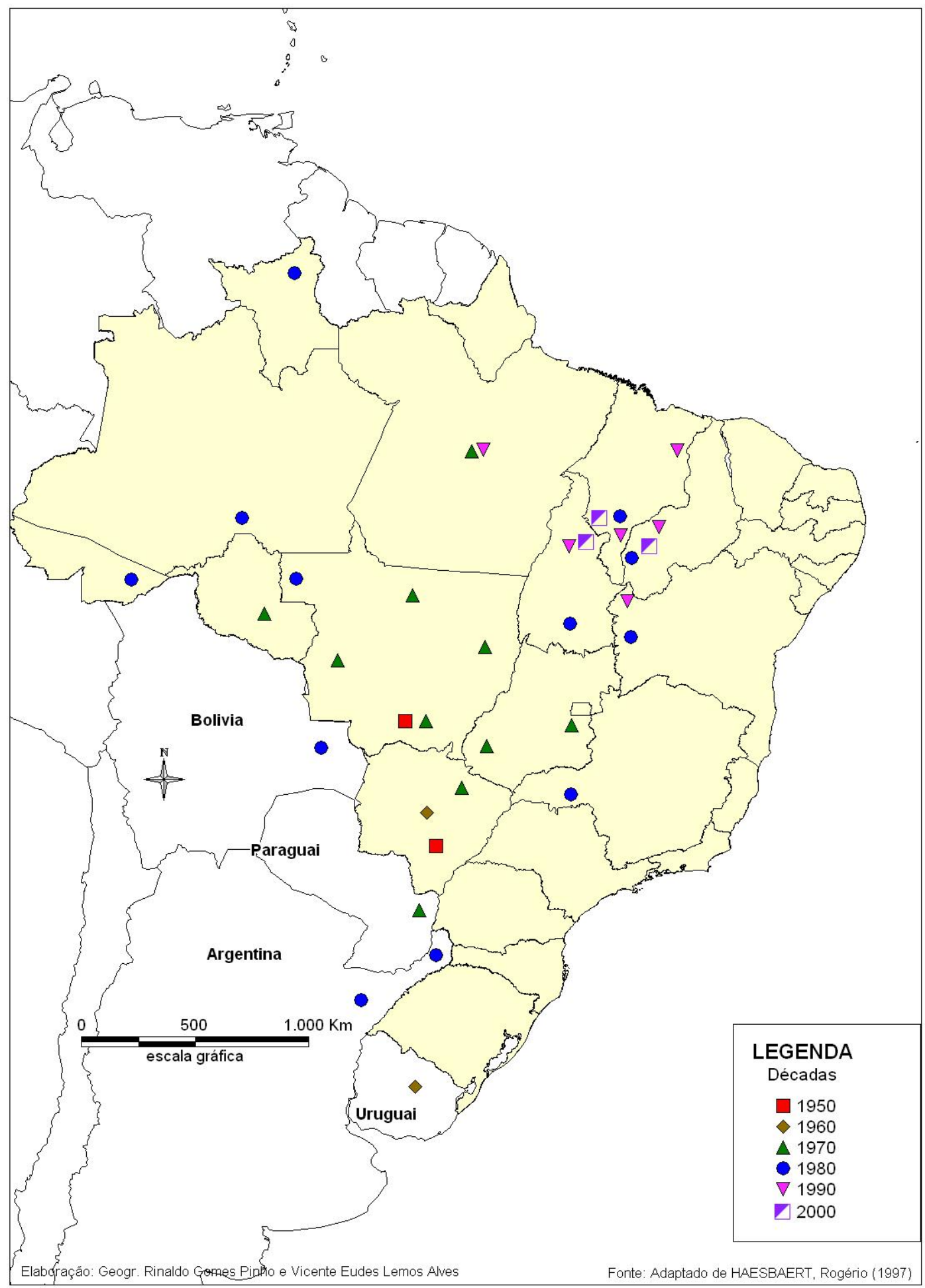


Mapa 12 - População Sulista nos Estados dos Cerrados Nordestinos

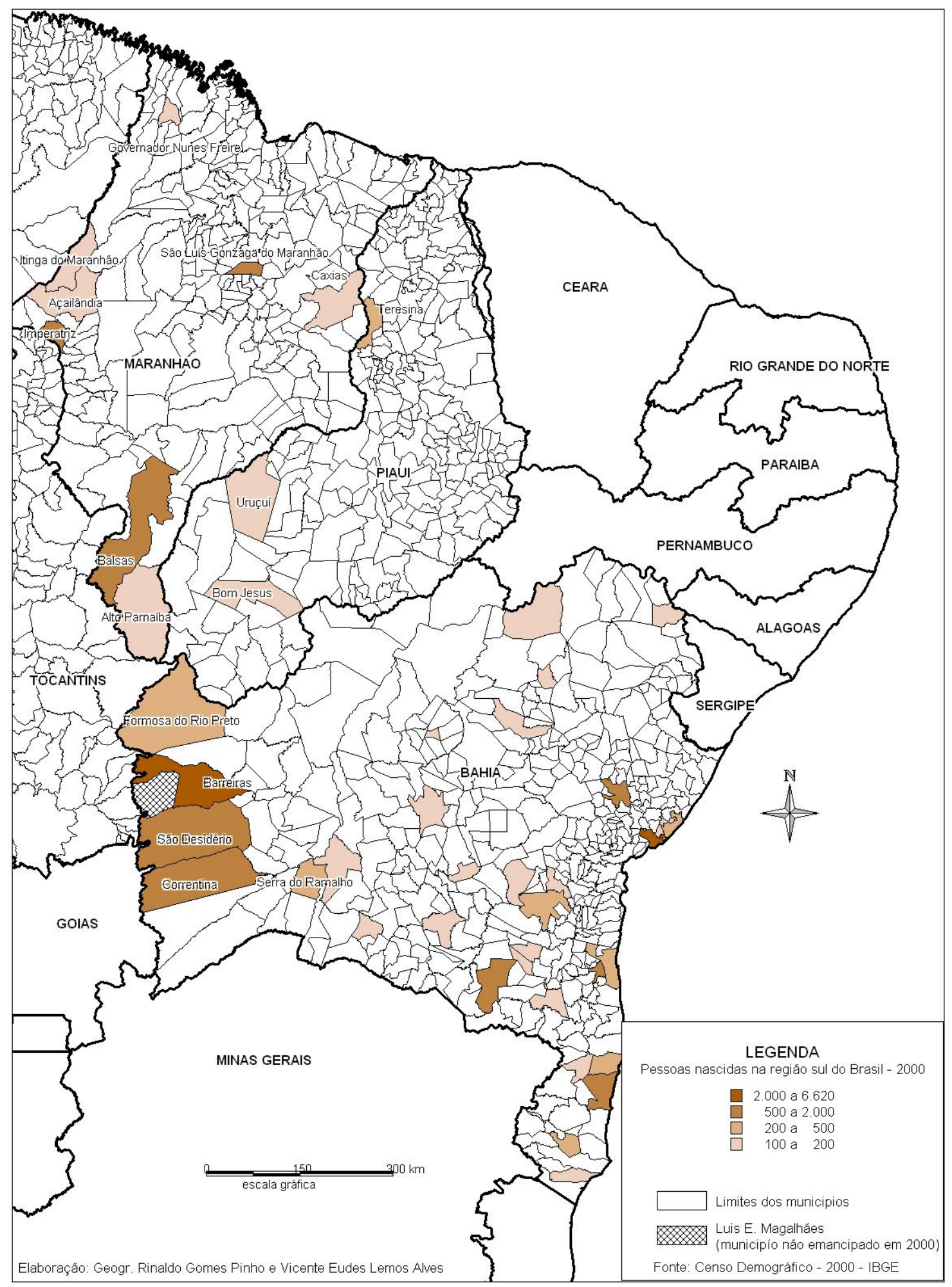


Os grupos populacionais que se deslocam para o Piauí são, em sua grande maioria, do Sul do Brasil, predominantemente gaúchos. Também chegam grupos de paranaenses e catarinenses (gráfico 08), mas todos são chamados de "gaúchos". Invariavelmente são descendentes de europeus, com vínculos marcantes com a agricultura. As áreas de onde saem no Sul do Brasil são aquelas pioneiras na produção agrícola de grãos, principalmente as do planalto meridional centro-noroeste rio-grandense, onde se localizam os municípios de Santa Rosa, Santo Ângelo, ljuí, Cruz Alta, região por onde a soja teve o seu primeiro impulso em terras brasileiras ${ }^{67}$.

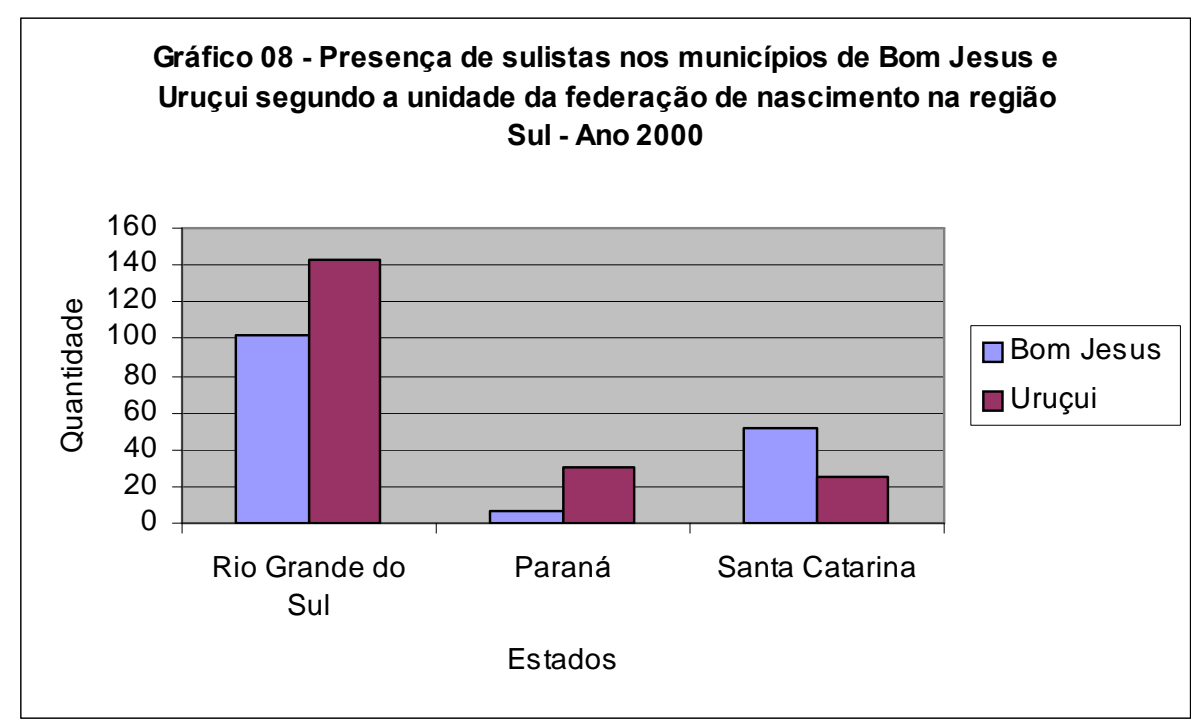

Fonte: IBGE - Censo Demográfico - 2000

A migração para os cerrados piauienses se caracteriza atualmente pela convergência de fluxos de sulistas de diferentes lugares: diretamente do Sul do Brasil, principalmente do Rio Grande do Sul e Paraná; dos estados do CentroOeste e do Norte; do oeste da Bahia e até mesmo do Paraguai. Não chegam mais em caminhões abarrotados de gente, como nos acostumamos

67 Segundo Santos (1993: 73) essa região foi estrategicamente escolhida como área de recrutamento de colonos para a ocupação da Amazônia. Tratava-se da região do Sul do Brasil com maior concentração de minifúndios e por onde o capital projetava expandir a agricultura de mercado, principalmente com a soja e o trigo. A opção foi então, por essas áreas, para tanto, o Estado teve participação fundamental no processo, ajudando na transferência da população camponesa, por indução ou por coerção, para os projetos de colonização que se formavam naquele momento na Amazônia. Articulava-se, ao mesmo tempo, repassar as terras dos que partiam para o agricultor modernizado (comumente 0 "lindeiro") que passa a concentrar terras naquela região. 
a ver na iconografia referente à ocupação do norte do Paraná ou, algumas décadas mais tarde, das terras do Brasil Central e da Amazônia. É freqüente, no entanto, encontrar excursões de ônibus com sulistas interessados em observar as condições das terras piauienses (foto 13). Dificilmente, quando resolvem comprar terra naquele estado, encaram sozinhos tais desafios. Estabelecem, comumente, parcerias: grupos de indivíduos com vínculos de parentesco, de amizade ou através de cooperativas. Costuma-se formar uma associação entre os migrantes num sistema de consórcio visando à aquisição de grandes extensões de terra. Nenhum migrante sulista, todavia, desembarca nos cerrados piauienses sem um volume razoável de informações a respeito das potencialidades das terras e das perspectivas de produção e escoamento das mercadorias da sub-região.

"Quase todos esses que a gente conhece, quase todos vêm com a família. Tem gente que chegou com a mudança em cima, mas, tem uma parte de proprietários aqui que têm propriedades aqui, são produtores, mas ainda moram lá no Sul. Deixam suas fazendas na gerência de uma outra pessoa"

(Dionésio Ferrari, paulista, de São José do Rio Preto, produtor agrícola e comerciante de maquinários agrícolas. Morou durante 23 anos no norte do Mato Grosso antes de migrar para Bom Jesus, no Piauí. Depoimento concedido em setembro de 2003).

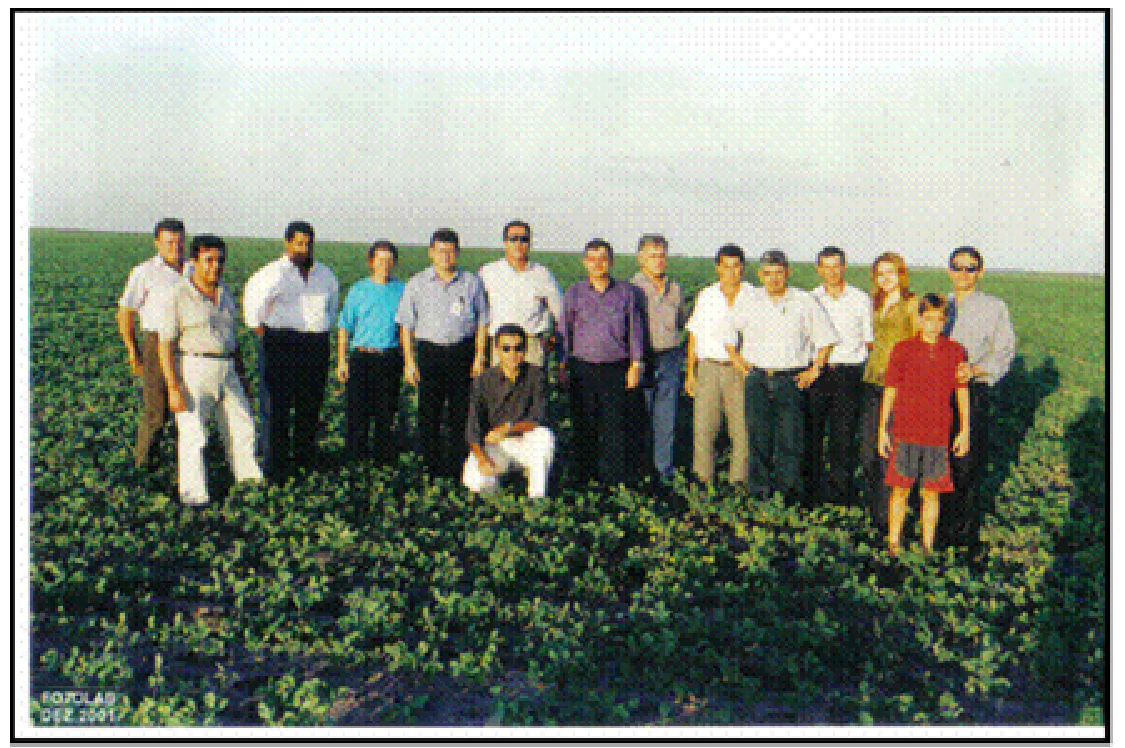

Foto 13 - Grupo de migrantes sulistas compradores de terra no sul do Piaul. Fotolab, juiho de 2001. 
As primeiras iniciativas para direcionar a migração sulista rumo aos cerrados do sul do Piauí partiram do próprio governo piauiense, que enviou, nos anos 1990, seus técnicos ou contratou empresas para a divulgação - a partir de diferentes meios de comunicação - dos cerrados. Apresentava-nos como a última fronteira agrícola brasileira à espera de exploradores com experiências em lidar com a agricultura capitalista para alcançar a modernização contemporânea induzida em outras áreas do Brasil. O Estado foi em busca desse produtor onde ele se encontrava, no Sul ou nas fronteiras agrícolas do Centro-Oeste, como nos esclarece o depoimento a seguir:

"Teve um pessoal daqui do Piauí que eles tiveram lá no Mato Grosso, em Água Boa. Era um pessoal do governo. Eles estiveram lá para conhecer o modelo de Água Boa, Canarana, porque lá é uma região (...), são cidades que já foram formadas exclusivamente pela agricultura. Foram formadas por intermédio de cooperativas do Sul que formou Água Boa, Canarana e outras cidades mais. Então, eles começaram a despertar na gente a curiosidade do Piauí, aí a gente veio; veio eu e um sobrinho meu pra cá, ficamos aqui uns dias, andando, conhecendo, conhecemos a primeira lavoura de arroz, a pioneira aqui na região"

(Dionésio Ferrari. Entrevista concedida em setembro de 2003).

Existiram outros agentes de propaganda dos cerrados piauienses, como os vendedores especuladores de terra que também traçaram suas estratégias de convencimento do futuro empreendedor do Piauí. Normalmente são gravadas fitas de vídeo com as informações a respeito da sub-região. Nelas são veiculadas as fazendas disponíveis para compra com suas características edafo-geográficas, localização das empresas compradoras de grãos; localização das fontes fornecedoras de calcário etc. Atualmente, há divulgação para venda das terras do sul do Piauí através de sítios da Internet. Ocorrem, ainda, situações em que os próprios migrantes sulistas, ao adquirir terras na região, passam a convencer seus parentes, amigos ou conhecidos a se mudarem para o Piauí, lembrando-os sempre das excelentes possibilidades de enriquecimento ao deslocar seus investimentos para as terras dos cerrados. $A$ construção dessa rede regional produziu um constante fluxo de pessoas entre os cerrados nordestinos e algumas cidades do Sul do Brasil. Do oeste da Bahia e do sul do Maranhão, várias empresas de ônibus fazem diariamente viagens 
para municípios sulistas e do Centro-Oeste. Um migrante localizado no sul do Piauí que deseja embarcar para essas regiões pode deslocar-se até Barreiras, Luis Eduardo Magalhães ou Balsas e de lá seguir para a área de destino. Essa rede torna-se bastante eficiente como estratégia de convencimento do sulista a ser um morador dos cerrados piauienses.

\subsection{1 - A corrente sulista e o encontro de suas ramificações nos cerrados piauienses}

Os fatores apontados acima contribuíram para que o sul do Piauí se revelasse, nos últimos anos, como uma região de encontro das distintas trajetórias desse grupo. Ou seja, os cerrados piauienses comportam-se atualmente como uma região de confluência de população sulista. Desembarcam naquelas terras, tanto parte da população que se desloca diretamente do Sul do Brasil, quanto sulistas estabelecidos em outras regiões,

principalmente em áreas que se constituíram anteriormente numa fronteira agrícola. Por isso, para melhor entendimento do processo de deslocamentos dos sulistas para Piauí, consideramos esse movimento divididos em dois grupos, mas de uma mesma corrente migratória. Isto é, esses migrantes pertencem a um mesmo grupo cultural, no entanto, é importante salientar que o seu espalhamento pelo território brasileiro produziu e produz ramificações. No nosso caso, classificamos uma das ramificações como fazendo parte do grupo que sai diretamente do Sul e, a outra, do grupo que se desloca das demais áreas de agricultura capitalista moderna. Esta última predomina amplamente nos cerrados piauienses. Os sulistas pertencentes a ela são os que, verdadeiramente, controlam os processos de aceleração da modernização agrícola sul-piauiense, no sentido de que são os que mais acumulam capital e terra nessa sub-região dos cerrados nordestinos.

Da ramificação que sai do Sul do Brasil diretamente para o Piauí faz parte um grupo de colonos gaúchos originários da região de Santa Rosa-RS. Sob o comando de uma cooperativa, esse grupo se instalou, em 1997, nos platôs planos de Uruçuí, distante cerca de 200 quilômetros da sede do município; junto à área adquirida formou-se um núcleo urbano: Nova Santa Rosa. 
O outro segmento de migrantes sulistas que se dirige ao Piauí resulta de uma ramificação ampla. Apesar das dificuldades de precisarmos em que momento se iniciou, no Sul do Brasil, o fluxo das famílias que chegam ao Piauí, sabe-se que muitas delas saíram de suas antigas áreas de colonização há vinte ou trinta anos, passando pelo Paraná, o Mato Grosso, o Mato Grosso do Sul, a Bahia e até mesmo o Paraguai ${ }^{68}$.

"Essas pessoas vieram do Mato Grosso, muitos vieram de Primavera do Leste; outros vieram da região de Dourados, tem um pessoal que vem de Rio Verde, têm uns que vieram de Canarana, tem de Barra da Garça, etc. Nos últimos anos tem bastante gente que vem do Paraná, Santa Catarina e do Rio Grande do Sul. Agora tem de outros estados: Rio de Janeiro, São Paulo, tem até da Bahia. Tem um pessoal que vem da Bahia pra cá, mas são provenientes todos do Rio Grande do Sul. (...)Têm pessoas que nasceram no Rio Grande do Sul, os pais se mudaram para o Paraná, daí partiram para o Paraguai e do Paraguai vieram para o Mato Grosso. Eu conheço um caso, que eles são natural do Rio Grande do Sul, são gaúchos, foram para o Paraná, do Paraná foram para o Paraguai e do Paraguai foram para a Bahia e da Bahia estão aqui. São vários casos desse tipo"

(Joabel Raabe, 21 anos, sulista do Rio Grande do Sul, morador em Bom Jesus. Entrevista concedida em setembro de 2003).

Ou seja, antes de seu desembarque nos cerrados piauienses, os sulistas já cumpriram duas ou três etapas de migração. Muitos deles nasceram na nova fronteira para onde seus pais migraram nos anos 1970 e 1980. Esses jovens, no entanto, também se intitulam sulistas e fazem questão de preservarem as identidades do Sul do Brasil. Vários desses migrantes que chegam ao Piauí foram responsáveis pela abertura, para a agricultura capitalista, dos cerrados e, por razões diversas, desfizeram-se de suas propriedades ou deixaram outros membros da família cuidando delas e seguiram adiante.

${ }^{68}$ Registramos no trabalho de campo uma presença significativa, nos municípios sul-piauiense (principalmente em Bom Jesus), de sulistas que saíram de Água Boa, no Mato Grosso. Isso indica a importância da rede que se estabelece com a migração. 
"Temos vínculo lá no Mato Grosso, porque a família da minha sogra, a família Riva são em oito irmãos, ficou um no sul e os outros sete irmãos estão em Primavera do Leste. Todos da família estão lá nessa cidade produzindo. A única família, desses sete, que veio para o Piauí foi a nossa, o restante está tudo lá em Primavera do Leste"

(Ana Luiza Secco, Sulista, moradora em Bom Jesus, ex-secretária da educação do município. Entrevista concedida em setembro de 2003).

Quando se toma a decisão de procurar novas terras, sem que se desfaça das conquistadas anteriormente, na maioria dos casos, são os filhos que seguem deixando seus pais ou familiares cuidando do patrimônio. Os argumentos desses migrantes para partir, normalmente rumo a uma nova fronteira, são invariavelmente os de que a antiga propriedade não comportava mais todos os herdeiros ou ela havia atingido o que se imagina ser seu auge de valorização. Por isso, a decisão de alguns ou todos os membros da família partirem para se tornarem donos de suas próprias terras ou, ainda, ampliarem o seu patrimônio. Tal situação fica evidente no depoimento que segue de um migrante gaúcho que passou pelo norte do Mato Grosso, antes de se instalar nos cerrados piauienses:

"A gente veio da região Sul, da cidade de Três Passos, que era uma região de minifúndio. Lá meu pai tinha 30 hectares, e aí a gente resolveu sair do Rio Grande do Sul e vir para o Mato Grosso (...). No Mato Grosso adquirimos 400 hectares. Era um loteamento de um ex-pastor da igreja luterana, ele fez esse convite, aí a gente veio pra Água Boa, onde não tinha nada, só cerrado. Isso foi em 1975, lá não tinha nada. Eu fui o primeiro que cheguei em Água Boa, tinha um matogrossense lá, que morava lá, tinha uma grande fazenda que ele comprou e loteou. Eu cheguei nesse matogrossense e ele me perguntou: - 'O que você veio fazer aqui gaúcho?'. Eu disse: - 'Eu vim plantar arroz'. Aí ele: 'Moço, vai embora, aqui não dá nada não';

Eu fiquei na minha, eu só olhei assim em volta da casa dele, eu vi só um pé de erva santa plantado. Então, eu deduzi que ele não era o homem para dar informação, porque ele nunca plantou. No primeiro ano em que plantamos nos demos bem, aí faltava o que pra nós, pra ter sucesso? Faltava estrada, faltava armazém, foi aquele corre-corre, e foi muitas famílias num tempo só que migrou, né. Então, sofremos muito no Mato Grosso. Foram 19 anos que convivi lá, aí chegou a história do Piauí. Lá no Mato Grosso o grande engole o pequeno. Aí encontrei um amigo em Goiânia, um corretor, ele falou: - 'Lá no Piauí temos terras baratas'. Aí vim conhecer aqui, vim em janeiro de 1994, cheguei bem na época da planta bonita, olhamos esses baixões. Me interessei por essas terras. Voltei para o Mato Grosso, ficamos lá um tempo, aí foi lá um diretor do BNB, foi lá e fez aquela propaganda de financiamento barato; o corretor mostrando as terras, ai veio aquelas levas, veio vindo cada vez mais gente" 
(Sr. Valdemar, gaúcho de Três Passos, passou pelo Mato Grasso, atualmente dono de churrascaria em Bom Jesus. Entrevista concedida em setembro de 2003).

Assim como no caso do migrante referido acima que, apesar de comprar terras, foi se dedicar à atividade comercial (no seu caso, montou uma churrascaria), outros se instalaram nos municípios dos cerrados piauienses como comerciantes de equipamentos e de insumos agrícolas e, às vezes, também de terras. Alguns deles dividem a rotina de atividades de comerciantes com de produtor agrícola.

Há, ainda, no universo de migrantes sulistas que passaram por uma outra fronteira, os trabalhadores com especializações: tratoristas, agrônomos, gerentes de fazendas, vendedores de insumos etc. Aqueles com melhor remuneração conseguem comprar terras, inclusive montando suas próprias fazendas; outros, entretanto, tornam-se trabalhadores proletarizados, principalmente os tratoristas ou pessoas que se dedicam a outras profissões similares. Não é difícil encontrar nos bairros pobres de cidades piauienses crescidas com o agronegócio, como Uruçuí e Bom Jesus, sulistas morando em residências precárias. Mas esses não são os que predominam, a maioria chega ao Piauí participando de um estrato social mais elevado quando se compara com o de uma parte significativa da população local.

Os sulistas que passaram por uma outra fronteira agrícola predominam como os detentores de melhores condições econômicas. Esses migrantes chegam nos cerrados piauienses com capital suficiente para comprar grandes extensões de terras e para montar unidades produtoras de grãos de médio e grande porte. Por vezes, ao longo de sua trajetória de deslocamento, foram acumulando riquezas, tornando-se, inclusive, grandes empresários do setor de agronegócios. Mas, na sua origem, muitos deles pertenciam ao campesinato sulista, congregando um perfil que Santos (1993: 80) identificou nos migrantes do Sul do Brasil que se deslocaram para a Amazônia: tratava-se, em geral, de pequenos agricultores ${ }^{69}$ que buscavam um pedaço de terra. Tal deslocamento,

${ }^{69}$ É importante salientar que nesse universo de produtores agrícolas do Sul que se deslocou para as fronteiras agrícolas da Amazônia havia uma diferenciação de classes no seu interior. Como ressalta Santos (1993:102) a respeito do projeto de colonização Canarana, no estado de Mato Grosso: "Em Canarana, produziu uma dupla diferenciação social entre os colonos, conferindo uma certa complexidade às relações sociais constatadas: primeiro, uma 
no mais das vezes, rumo a uma nova fronteira, representava o sonho da liberdade, de conquistar o trabalho autônomo, como ressalta o autor:

"[...] O outro aspecto é a vontade de abandonar o trabalho manual, a pá, a enxada, a picareta e o arado puxado a bois, para trabalhar com máquinas: a vontade de ter uma plantação mecanizada. Enfim, dizem eles, se a gente tem terra, tem também liberdade no próprio trabalho, e nem pais nem filhos precisarão trabalhar como peões, como assalariados agrícolas. O projeto desses camponeses do Sul que partiram para Canarana, esta 'influência', estendeu-se a diversas dimensões. Todos foram motivados pela falta de terras: uma terra que pudesse dar a eles e a seus filhos a possibilidade de também serem camponeses que não precisam trabalhar com tanto esforço, porque mecanizaram o trabalho. Uma terra que Ihes dê a possibilidade de ter a liberdade de um trabalho autônomo. Foi esse projeto que, face a uma situação de expulsão, fê-los escolher este destino de colonos, de preferência a qualquer outro que também fosse possível. Esses colonos do Sul queriam partir para novas regiões para realizar seu sonho de terra (...)".

Os migrantes sulistas que chegam aos cerrados piauienses, após experiências em outras fronteiras agrícolas, lograram realizar o sonho de autonomia relativa, na medida em que, a maioria deles, deixou a condição de agricultores sem ou com pouca terra e se inseriram na de proprietários, detentores, em muitos casos, de grandes extensões de terras, como fica evidente no texto e nas falas que se seguem:

"Os pioneiros da soja no Piauí têm origem e perfil semelhantes aos desbravadores do cerrado no Centro-Oeste, de 20 anos atrás. A maioria carrega sobrenomes de origem alemã ou italiana, quase todos com raízes no Sul do País, mas há também alguns paulistas. São movidos pelo espírito de migração e a vontade de expandir horizontes. 'Eu me criei em cima de 33 hectares na região de Cruz Alta, no Rio Grande do Sul, e hoje me sinto feliz porque consigo ajudar meus irmãos e meu pai', resume o produtor Max Plentz, dono de uma lavoura de 1,6 mil hectares na Chapada do Quilombo, município de Bom Jesus, próximo ao rio Gurguéia, quase no extremo Sul do

diferenciação entre grupos de colonos de condição social semelhante, mas com diferentes estatutos, no que diz respeito à terra, no programa de colonização. Uma diferenciação vertical, uma estratificação social, poderíamos dizer, que se estabelece entre os colonos segundo o tamanho da propriedade ou o tipo de meios de produção que possuem". Brum (1988), do mesmo modo, faz ressalva a respeito desse agricultor sulista que se desloca para as fronteiras agrícolas. Segundo tal autor, trata-se de agricultores que já eram médios e grandes (lá) no Sul. Realmente, encontramos na nossa área de pesquisa produtores que já saíram do Rio Grande do Sul ou do Paraná como grandes agricultores. Isso, no entanto, não é o que predomina no universo de migrantes sulistas que chega aos cerrados piauienses. 
Piauí. A área total da fazenda São Pedro, uma homenagem ao nome do pai, é de 15 mil hectares. 'Aqui temos o mundo para fazer', continua. Antes de chegar ao cerrado piauiense, Plentz comprou 3 mil hectares em Água Boa (MT), para realizar o desejo de possuir uma 'pecuária maior'. O Piauí o atraiu pela vontade de plantar soja, atividade original da família no Sul. Nos chapadões encontrou terra a preços mais baixos que em Mato Grosso, que 'já não é mais fronteira'. A soja também alcança preço melhor no Piauí". (In O Estado de S. Paulo, 20/09/2002).

“(...) Esse pessoal que vem do Mato Grosso, do Paraná, é um pessoal que já se instalou, eles têm um capital maior, os que saíram diretamente do Rio Grande do Sul é um pessoal com maior dificuldade".

(Cleimor Gerloff, gaúcho de Santa Rosa, morador em Nova Santa Rosa. Entrevista concedida em setembro de 2003).

"A mobilidade social ocorre principalmente com o pessoal que ocupou a Serra do Quilombo. Lá têm mais pessoas que saíram do Rio Grande do Sul e foram para o Mato Grosso, e agora compram cinco a dez mil hectares na Serra. Com o pequeno que saiu direto do Rio Grande, isso não acontece, porque ele tem que se enfiar lá no meio do mato, porque ele tem pouco dinheiro, tem que se sujeitar não só ao sacrifício na lavoura, mas também à falta de infra-estrutura das estradas".

(Lourival Bublitz, representante da Cotrirosa-Cooperativa Tritícola Santa Rosa). Entrevista concedida em julho de 2005 no município de Luis Eduardo Magalhães BA).

Tais depoimentos confirmam, desse modo, que o migrante sulista, em sua passagem por outras fronteiras agrícolas, metamorfoseia-se, na maioria dos casos, de camponês em produtor agrícola bem sucedido. De explorado, às vezes, transforma-se em explorador da força de trabalho alheia, seja de alguns de seus conterrâneos ou da população camponesa piauiense que se emprega precariamente nas fazendas produtoras da agricultura moderna. Dificilmente esse migrante aproveita apenas a força de trabalho de sua família, freqüentemente contrata $\circ$ trabalhador assalariado. Esse grupo se insere, nesse sentido, na condição de produtor rural capitalista e não mais na de camponês, salvo algumas exceções.

Além do poder aquisitivo maior, os migrantes que saem de uma outra fronteira agrícola apresentam algumas características que também os diferenciam daqueles que atualmente se deslocam diretamente do Sul do Brasil para os cerrados do Piauí. Trata-se do fator cultural. Apesar de carregarem os 
costumes do Sul e irem reproduzindo-nos onde se instalam, o tempo de afastamento e a convivência com culturas de outras regiões, onde inclusive muitos nasceram, permitem maior tolerância ou receptividade a outras manifestações culturais. Nesse sentido, a identidade desse grupo já se ressente da distância de tempo e de espaço do núcleo de onde se irradiou um estilo de vida, marcado pela idéia do tradicionalismo. Uma certa corrosão dessa identidade permite que os migrantes aceitem de forma mais espontânea alguns comportamentos da cultura piauiense, até convivendo e se relacionando com ela em algumas manifestações da vida cotidiana local. Não é difícil encontrarmos sulistas em festas de piauienses, embalados pelo ritmo do forró, ou assistirmos casamentos mistos de sulistas com nordestinos.

Entre os migrantes sulistas que saíram diretamente do Rio Grande do Sul para o Piauí, como no caso dos gaúchos originários do noroeste riograndense, no entanto, o distanciamento em relação à cultura piauiense tornase mais visível. O estranhamento ao modo de vida nordestino é evidente. São grupos mais fechados no sentido de pouco ultrapassar nos seus relacionamentos particulares os limites da sua rede social afetiva e familiar, que, nesse caso, congrega pessoas não somente com proximidade cultural, mas também geográfica e de certas condições sociais (foto 14).

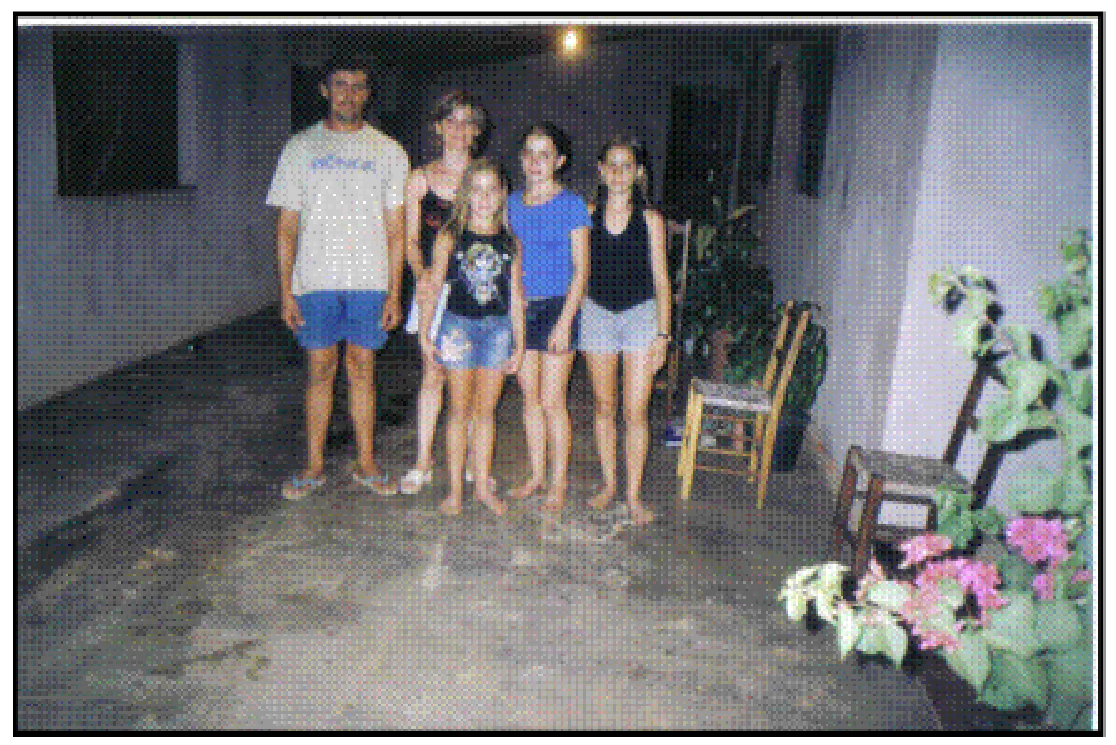

Foto 14 - Jovem familia gaĹcha instalada em Nova Banta Rosa. Foto do autor, setembro de 2003. 
$\mathrm{Na}$ área onde se pretende executar o projeto da futura cidade de Nova Santa Rosa, cujos moradores têm o desejo de que se transforme brevemente em um município, parece que a cultura gaúcha impregna muito mais o cotidiano. Os novos habitantes do lugar procuram reproduzir um estilo de vida idêntico àquele deixado em seu lugar de origem. As músicas tocadas na única pousada do núcleo urbano são quase todas com sotaques de descendentes de italianos ou alemães, como são características no Sul do Brasil. O mesmo ocorre com a arquitetura de várias das casas, reproduzindo o estilo do Sul (foto 15). Os traços étnicos logo denunciam a composição demográfica daquele lugar; pouco se vê vestígios de pessoas de cor de pele mais escura, o que denunciaria a presença de piauienses. Encontram-se apenas alguns trabalhadores braçais piauienses (homens, mulheres e crianças) instalados em galpões ou em outros tipos de moradias improvisadas, mas nenhum deles com residência fixa. O local de moradia desses últimos ocorre nos vales.

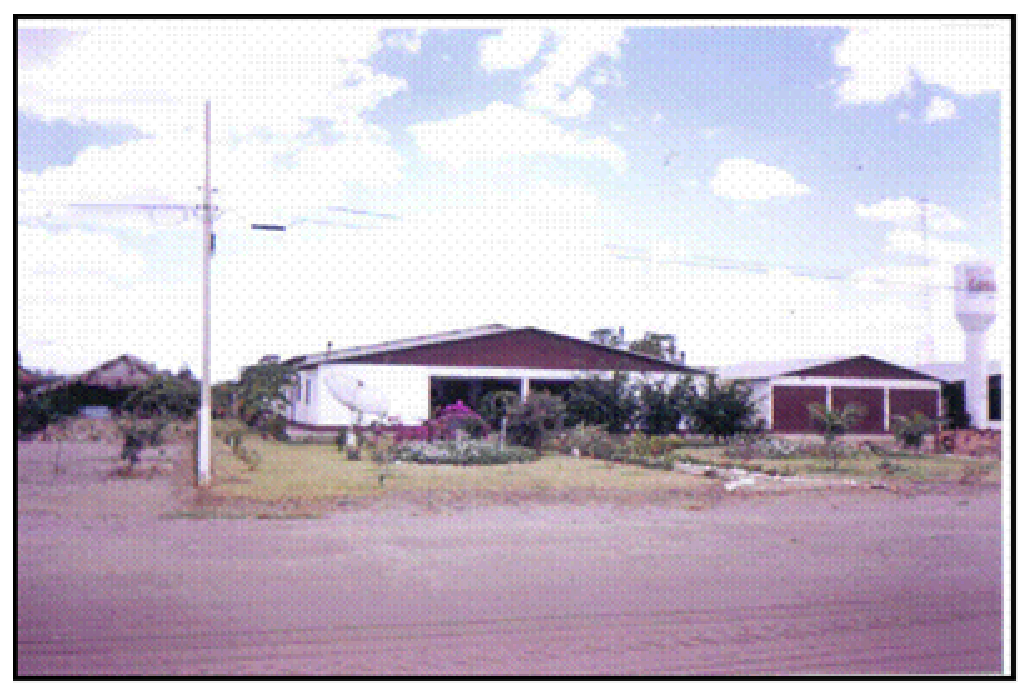

Foto 15 - Residencias instaladas em Nova Santa Rosa - a arquitelura das casas demonstra a influencia cultural dos migrantes sulistes na atual organizaça do espaço dos gerais piauienses. Foto do autor, setembro de 2003.

Nova Santa Rosa destoa também das áreas de ocupação dos piauienses pela aceleração das mudanças espaciais e pela forma como os moradores daquela área se apropriam do tempo de trabalho num ritmo muito mais intenso. No momento em que estive na agrovila, em setembro de 2003, as máquinas agrícolas trabalhavam ininterruptamente 24 horas por dia, 
havendo apenas revezamento de trabalhadores. À noite, observavam-se aqueles grandes objetos em movimentos contínuos, como se fossem "vagalumes gigantes", nos extensos platôs planos da chapada. Isso, entretanto, não se restringe a um período sazonal, mas prevalece a maior parte do ano, pois quando não é época de plantio, é de preparo da terra, ou é de colheita, ou ainda, é de armazenar para posteriormente enviar o produto à fábrica esmagadora. Quase não há tempo para as festas, nem ao menos para visitar um vizinho. Somente aos finais de semana reúnem-se para desenvolver algumas atividades coletivas: o culto luterano ou católico; algumas práticas esportivas, como o jogo de bocha, do qual participam os jovens e os mais velhos.

Apesar das diferenciações entre os indivíduos da corrente sulista, a identidade do grupo prevalece e os migrantes fazem questão de difundi-la, onde quer que estejam. A instalação dos CTGs (Centro de Tradições Gaúchas) é uma maneira de manifestar suas preocupações em reiterar tais identidades, principalmente a identidade gaúcha (Haesbaert, 1997). Mesmo não existindo ainda esses centros (mas, com projeto de construção) no sul do Piauí, os novos moradores manifestam preocupações em reforçar e divulgar suas "tradições" quando aparecem as oportunidades: nas festas dos padroeiros das cidades piauienses, nas ocasiões em que os próprios "gaúchos" organizam reuniões familiares, nas exposições e/ou feiras de maquinários agrícolas etc. (foto 16).

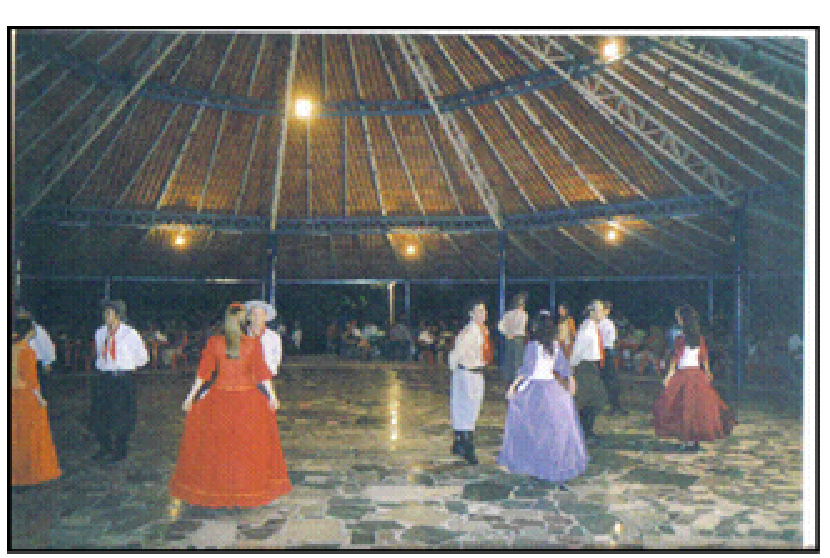

Foto 16 - Agresentaya do danca follotica sulsta na "Ptimeira Feste Gaukha de Bom desus". Foto do autor, outubro de 2003
Nesse independentemente de que caminhos percorreram até chegar ao Piauí, os costumes permanecem na trajetória do grupo. Uma dessas manifestações foi presenciada quando me encontrava em Bom Jesus, em outubro de 2003. Tratava-se da

denominada "Primeira Festa Gaúcha do Município de Bom Jesus". Nela, apareceram sulistas de vários municípios dos cerrados piauienses. As 
vestimentas seguiam os costumes do Sul, assim como o cardápio, com o tradicional churrasco. Havia poucos piauienses, a não ser algumas autoridades locais. Outro fato que nos chamou a atenção foi o discurso apresentado na abertura da festa preparado por uma jovem, no qual ela conclamava os presentes a preservarem os costumes dos pampas, como segue:

"Tomados pelo ritmo da gaita, do violão, da bateria e do canto do gaiteiro. De mãos que se apertam, se cumprimentam, corpos que se abraçam, se encontram, rostos que sorriem e observam. E não é para menos!

Nessa noite, muitas famílias sulistas, residentes nessa região, encontram-se com tantos outros irmãos rio-grandenses e também com amigos da sociedade bomjesuense, ansiosos por participar de um evento pioneiro de demonstração de nossa cultura.

O ambiente ainda não é, em seu espaço físico, um Centro de Tradições Gaúchas, com todos pilchados, onde o patrão e a patroa acolhem a indiada animada.

Mas isso não é motivo para dar menor brilho ao momento. Encontrarão razões maiores que vão tornar a noite um sucesso. Vejam:

- Muitos gaudérios de bombacha, prova de que têm sangue quente de farrapos;

- Muitas gurias em seus vestidos de prendas, símbolo da beleza e autenticidade de nossa mulher gaúcha, as quais preservam nossa tradição livre da invasão dos modismos;

- E, ainda, os piazitos, esses repartem conosco suas alegrias e orgulho das conquistas de nossos antepassados;

- Verão também uma comunidade de muita coragem, que nasceu ao som do minuano e hoje queimam o lombo no calor do sol nordestino;

- Terão grande prazer de ver o que para nós é uma das maiores expressões de nossa herança gaúcha - "Grupo Tradição".

É nesse momento que me faço porta voz da 'Família Tradição', para agradecer a presença de todos e o brilho que cada um possui nos olhos ao assistir esta 'chama de cultura criola'.

Acredito ser a hora oportuna de lembrar da história do tradicionalismo - onde há muito tempo o primeiro gaúcho foi obrigado a deixar a Campanha para viver na cidade - nasceu a tradição - porque esse gaúcho teve saudade do seu cavalo, da liberdade sem fim dos campos, da vida campeira e do chimarrão. Então mesmo na cidade ele continuou a comer churrasco e tomar mate e a usar expressões, ditados e palavras aprendidas na Campanha.

Nós, todos, não fomos obrigados a deixar nossas terras, como o gaúcho da história. Somos um grupo, que por opção decidiu viver em outra região para ampliar nossas fronteiras. Surge o tradicionalismo - a saudade de nossos costumes. Nasceu com isso - 'Grupo Tradição'.

Com muito Brilho, nessa noite, dançam para vocês - 'Grupo Tradição'”

(Rosane. Bom Jesus, 04 de outubro de 2003). 
Tal discurso mostra um forte apelo à manutenção da identidade "gaúcha" onde quer que o grupo esteja confirmando uma marca que acompanha o deslocamento desse grupo regional. Nesse sentido, é possível diferenciá-la, na sua essência, das demais correntes migratórias ocorridas no território brasileiro, pelo fato dela ser a única a demonstrar uma manifestação consciente da manutenção de um estilo de vida. Quero dizer que a identidade regional gaúcha não se difunde naturalmente como parte intrínseca de formação dos grupos culturais deslocados, mas é propositadamente "reterritorializada" no percurso seguido pelos migrantes.

A difusão dessa tradição cultural se origina numa região específica do Rio Grande do Sul, a dos pampas gaúchos de colonização portuguesa, cuja atividade econômica associa-se à pecuária. A pecuária forjou naquelas terras sulinas, da mesma maneira como a definida por Abreu (1969) para o caso da ocupação do interior do Nordeste brasileiro, uma civilização do couro. As constantes guerras contra os vizinhos de origem espanhola da Cisplatina e contra os índios guaranis e gês (grupos étnicos praticamente dizimados pelo avanço lusitano na região pampeana gaúcha) ajudariam a construir a imagem de um colonizador branco destemido e desbravador, o que viria a personificar a figura do novo gaúcho, fundada ao longo do século XIX, conforme nos esclarece Roche (1969: 21):

"Foi, por outro lado, o período em que desapareceram os primeiros gaúchos. Mestiços de brancos e índios guaicurus, tinham vivido em grupo originário à parte das raças de que saíram, vagueando pela planície. Rechaçados pela apropriação da terra, foram dizimados pelas guerras. Os sobreviventes extinguiram-se nas estâncias que cobriam a campanha, e nenhum novo rebento pôde brotar do tronco indiano, arrancado do Rio Grande do Sul. O nome gaúcho perdeu, então, o que havia podido ter de pejorativo e designa doravante o homem do cavalo, o criador, o habitante do pampa, de origem lusitana".

A construção da imagem da virilidade gaúcha frente aos outros habitantes brasileiros aparece em outro trecho do mesmo autor citado: 
"Os viajantes que vinham do norte ou do centro do Brasil admiravam-se da estatura e da figura dos rio-grandenses: os homens eram mais brancos, mas altos, mais robustos, mais viris que nas outras capitanias; também mais enérgicos e mais ativos. Isso provinha, diz-se, de seu regime alimentar. No Rio Grande, realmente, a alimentação, que parecia nada custar, era abundante e forte, à base de churrasco (carne assada sobre brasas), de farinha de mandioca e de chimarrão, infusão de erva-mate cujo amargor passa por combater os excessos de carne desse regime. Nem açúcar, nem sal, inexistentes no Pampa. O único 'doce' era o cigarro 'crioulo': o gaúcho corta meticulosamente, com sua faca, delgadas lâminas de fumo de corda, esmagaas, durante muito tempo, nas palmas da mão, e enrola, enfim, seu fumo numa folha de milho, acende-o com um tição do 'fogão', saboreia-o sentado sobre os calcanhares, na sua posição de repouso, depois das horas passadas na sela. O que, com efeito, distinguia o rio-grandense dos habitantes do resto do Brasil, era sua aliança com o cavalo. Montava-o com destreza, atravessando o imenso pampa, formando com ele um só corpo nas batalhas, mas tratava-o com um cuidado ciumento e aparelhava-o luxuosamente" (p. 26).

Essas manifestações da denominada cultura crioula, que embora tenham moldado um certo sentimento de identidade em todo o Rio Grande do Sul, estiveram pouco presentes nos planaltos Rio-grandenses onde predominou a colonização alemã e italiana, sustentada na pequena propriedade agrícola, e de onde irradiou a corrente migratória gaúcha para a fronteira agrícola. Esse discurso ressurge, entretanto, nessas áreas de aceleração da modernização para evocar o sentimento de uma regionalidade gaúcha.

\section{5 - O trabalho como elemento diferenciador entre o sulista e o piauiense}

Se, por um lado, nas fronteiras agrícolas do interior do Brasil forja-se a identidade sulista apoiada na idéia de uma certa superioridade "étnica", nascida ainda nos pampas gaúchos de predominância da pecuária, por outro lado, ela se reforça através da construção de uma outra imagem, desta vez difundida pelos imigrantes europeus colonizadores dos planaltos Rio-grandenses, qual seja, a do trabalhador. Essas duas representações se moldam e se difundem na trajetória migratória inicialmente do gaúcho e, posteriormente, do sulista em geral. A ética do trabalho embutida na mentalidade dos representantes da corrente sulista constituirá um fator importante de diferenciação frente aos 
outros grupos com que o sulista manterá contatos na fronteira, especialmente com os nordestinos (Haesbaert, 1997).

O trabalho para o sulista que migra para a fronteira agrícola representa tornar-se livre de uma antiga situação de privação financeira encontrada em seu lugar de origem. A inexistência ou a insuficiência de terra no Sul não permitia ao colono conceber um outro futuro, a não ser o de transformar-se em trabalhador explorado. Deslocar-se para a fronteira para ser proprietário é o que garantirá trabalho para toda a família e, ao mesmo tempo, a possibilidade de transpor a sua antiga condição de pequeno agricultor. A materialização do trabalho na terra, medida normalmente pela quantidade de hectares produzidos, é o que vai permitir, portanto, ao migrante sulista ser seu próprio patrão e, por ventura, até mesmo, conseguir superar a escala da reprodução das necessidades, tornando-se um produtor em larga escala de mercadorias para o mercado global. Quando atinge esse estágio de superação de sua condição anterior, passa a ser um explorador de mais-valia. Ele servirá, nesse caso, de espelho para outros migrantes que seguem rumo à fronteira agrícola. A respeito da importância que o trabalho adquire para o sulista que migra rumo à fronteira agrícola, a partir do qual busca atingir a libertação de uma condição anterior de limitações econômicas e o ingresso em outra, de produtor e consumidor de mercadorias, aponta Martins (1997: 126), ao analisar os discursos das crianças filhas de sulistas moradoras em Canarana-MT, a respeito do processo migratório desse grupo:

“(...) A diferença entre a situação atual e a anterior é que lá no Sul o crescimento da família e o crescimento dos filhos geravam uma escala de necessidades que não podia ser atendida pelo trabalho. Fosse porque a terra disponível não absorvesse a força de trabalho existente, fosse porque retribuísse com produção proporcionalmente menor do que o trabalho nela investido. Já no Mato Grosso, a terra pode absorver todo o trabalho da família. Mais ainda, o trabalho é insuficiente para ocupar toda a terra existente. Essa insuficiência é suprida por tecnologia. No Sul, ela estava limitada ao arado e ao boi. No Mato Grosso, envolveu o trator e a colheitadeira. A incorporação de equipamentos e técnicas muito mais avançados é o meio de conciliar a relação entre a terra e o trabalho, de maneira equilibrada. Nos dois casos, concretamente, é o trabalho o núcleo articulador e definidor da tecnologia empregada. O colono gaúcho vive sob o primado do trabalho". 
No universo da migração sulista nos cerrados piauienses se cria uma representação muito próxima ao de outras regiões de fronteira agrícola. Ou seja, freqüentemente atribui-se ao migrante sulista a idéia de sua disposição para o trabalho, por isso que no imaginário dos piauienses, corroborado pelos próprios migrantes, não se vê um sulista pobre; todos pretensamente apresentam boas condições de vida ${ }^{70}$. Por outro lado, o juízo que se faz dos piauienses freqüentemente é o oposto ao dos sulistas: são vistos como um grupo mais festeiro do que trabalhador, resultando daí a pobreza de uma grande parcela daquela população. Dessa visão participam tanto os sulistas quanto uma parte dos próprios piauienses.

Há também estranhamento entre a população sulista quanto à regularidade e ao tempo de duração dos festejos, que ocorrem por conta da homenagem aos padroeiros (tradição da cultura religiosa brasileira muito presente fora dos grandes centros urbanos) de cada município dos cerrados piauienses. Essas manifestações demonstram a permanência de uma religiosidade rústica ainda presente no seio de tal sociedade. Nesse caso, a duração de tais festividades chega a vários dias, nos quais participam intensamente uma significativa parcela da população. Além disso, quando um município é próximo de outro ou realizam-se as festas nos povoados ("as festas do interior"), esses lugares costumam receber um grande número de pessoas que se desloca a fim de participar também dessas ocasiões. Enfim, a festa é parte do universo de vida da população dos cerrados piauienses, o que a aceleração da modernização contemporânea ainda não se encarregou de destruir totalmente. A modernização, nesse caso, não é apenas produtora de processos não homogêneos sociais e econômicos, mas também esses processos se manifestam pelas formas do passado que permanecem tensionadas por aquelas do tempo único da globalização atual.

A tentativa de homogeneização através da mediação do trabalho também se coloca como campo de tensão entre os dois grupos regionais, o sulista e o piauiense. Várias situações presenciadas nas pesquisas de campo nos cerrados piauienses, onde percorremos algumas fazendas de sulistas nas

${ }^{70}$ Souza Santos (2003), em sua monografia de especialização, realizou um levantamento estatístico com 50 famílias migrantes sulistas que residiam em Bom Jesus, os dados apontaram que $87,6 \%$ dessas famílias apresentavam renda familiar de quatro ou mais salários mínimos. 
quais havia trabalhadores piauienses, e nas cidades onde presenciamos uma convivência mais intensa de tais grupos, confirmam tal premissa. Nesse sentido, foi bastante ilustrativo uma das entrevistas que realizamos, em 2003, com um migrante sulista produtor de soja, recém-instalado no Piauí. Nela, ele nos reclamava que, por ocasião dos festejos do padroeiro do município de Bom Jesus, todos os seus funcionários piauienses abandonaram subitamente 0 serviço na lavoura de soja sem maiores justificativas; tal migrante deduzira, então, que o motivo real fosse a participação deles nas festas, já que era o período de tais manifestações naquele município. Realmente, ao entrevistar alguns trabalhadores piauienses que prestavam serviços naquele momento para os sulistas, nos relatavam das angústias que possuíam em trabalhar cotidianamente nas áreas de serras sem muito contato com as pessoas, longe da família e da cidade, em condições precarizadas e ainda em tarefas repetitivas, em que o cumprimento de horários rígidos os aborreciam, diferentemente de quando lidava com as suas roças, em que o controle do tempo era flexível. Em épocas de festejos esses questionamentos tornavam-se mais freqüentes, pois tais ocasiões representam o momento do encontro com os familiares e com os amigos, muitos vindos de outros lugares, como São Paulo e Brasília. Em situações como essa não havia outra opção senão abandonar a ocupação nas lavouras agrícolas modernas.

A imposição ideológica do trabalho apresenta, dessa forma, resultados distintos quando se trata dos dois grupos. Para um, o sulista, o trabalho é a possibilidade de manter a propriedade e com isso garantir um bem estar para os atuais e os próximos herdeiros; para tanto, dedica-se com afinco, a partir da mediação da agricultura moderna produtora de grãos, às atividades que permitem assegurar um futuro mais promissor para a família. O capital, representado às vezes pelas grandes empresas, aproveitará essa ideologia para impor suas condições de reprodução. Para o outro, o piauiense, quando se trata principalmente do campesinato, o trabalho ainda é mediado por sua relação com a natureza, que deve ser exercido de acordo com as necessidades concretas da família, portanto, a imposição do trabalho abstrato ainda não se completou totalmente. A nova modalidade de reprodução do capital, que se manifesta pela organização da agropecuária em bases capitalistas modernas, tem dificuldade de se impor sobre os trabalhadores 
piauienses. Apesar disso, o capital fará uso da força de trabalho local aproveitando-se das levas de camponeses expropriados, adotando inclusive métodos coercitivos ou impondo-lhes condições extremamente precarizadas para poder se reproduzir, como veremos no próximo capítulo.

\section{6 - As características sócio-econômicas do migrante sulista nos cerrados piauienses}

O perfil etário dos migrantes sulistas é composto, em sua maioria, de jovens, alguns ainda solteiros, outros recém-casados com filhos ainda pequenos ou sem filhos. Mas, também, é possível encontrar casais mais velhos com família já constituída, os quais migram com todos os membros ou alguns deles. Há casos em que seguem para o Piauí dentro de um mesmo núcleo familiar, os pais, os filhos e os netos. Situação muito comum é a de acompanhamento do membro paterno ou materno que perdeu seu companheiro(a) e que passa a viver com os filhos (foto 17).

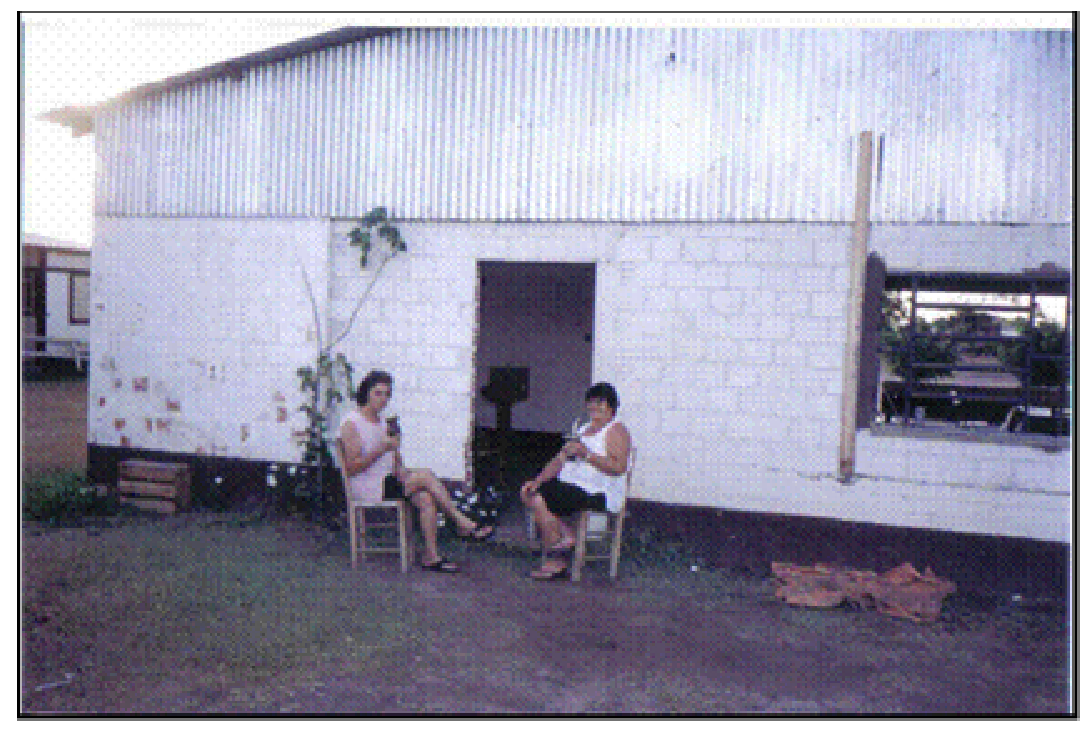

Foto 17 - Senhoras gauchas moradoras da agrovila Nova Santa Rosa. Foto do autor, setembro de 2003.

Muitos dos migrantes se desfazem da terra no Sul e de seus pertences móveis ou carregam consigo apenas o que é possível. Outros vão deixando os familiares ao longo de suas trajetórias. Ou seja, migraram os pais com seus 
filhos ainda pequenos para uma fronteira agrícola; os filhos cresceram e constituíram novas famílias, julgando necessária a construção de seu próprio patrimônio. Muitos migram com o projeto de possuir mais terras, pois as adquiridas por seus pais, em outro momento, não permitiam abrigar a todos os membros, ou o partilhamento da propriedade dificultava o sonho de se tornar um produtor capitalista. Decide-se, então, que alguns deverão partir em busca de novas terras, freqüentemente os jovens e/ou os que já adquiram alguma experiência no trabalho na lavoura que lhe habilite partir em busca de novos desafios. O perfil etário dos migrantes que chega aos cerrados piauienses é mencionado nas palavras de um sulista recém-instalado na região:

"O perfil de pessoas que chegam é em geral de meia idade, apenas algumas pessoas idosas que vieram com seus filhos, mas dá para dizer que os que chegam aqui tem aproximadamente 30 anos, ou de 30 a 40 anos, não mais velhos que isso. Essas pessoas ainda têm todo o gás para tocar a lavoura"

(Cleimor Gerloff, sulista de 27 anos. Entrevista em setembro de 2003).

Há uma inclinação entre esses migrantes para o trabalho na terra, ou por serviços que possuem alguma relação com a agricultura, preferencialmente, modernizada. A grande maioria dessa população adquiriu terras nos cerrados piauienses individualmente ou através de associação entre familiares, às vezes em sociedade com antigos vizinhos ou amigos. Em alguns casos é possível encontrar proprietários até mesmo entre aqueles que se deslocaram para empregar-se em reparos de maquinários nas fazendas agrícolas. Estes trabalhadores, contudo, já não representam mais um contingente tão considerável nos cerrados piauienses por exigirem salários mais elevados ou, em muitos casos, porque os próprios proprietários passam a executar tais serviços. Os trabalhos de aração da terra realizados pelos tratoristas, os quais num momento imediatamente posterior à chegada dos primeiros agricultores modernos ficavam a cargo dos sulistas, agora são repassados para os piauienses que aprenderam a realizar esse tipo de serviço. Mesmo porque, com a contratação desses últimos, o preço da mão-de-obra reduz significativamente, favorecendo, assim, a ampliação dos lucros dos donos de projetos agropecuários, como fica evidente no relato que segue: 
"Hoje a maioria dos trabalhadores é daqui, o peão do Sul ele não se adapta, aí ele não vem pra ganhar pouco. Então, hoje a gente já pega a mão-de-obra daqui, que fica mais em conta. O trabalhador daqui não sabia mexer com maquinários, mas ele aprendeu quando nós chegamos aqui. Antes eles só juntavam garranho, como se fala, hoje já tem muitos tratoristas, então tem muito peão daqui, quase todos fazendeiros do Sul tem um ou dois empregados daqui"

(Valdemar Gali, sulista de Três Passos-RS. Entrevista concedida em setembro de 2003).

Muitos dos migrantes que chegam ao Piauí implementam algum tipo de produção agrícola na propriedade adquirida. Há, porém, aqueles que compram a terra e deixam-na valorizando, à espera dos que chegam ou dos que chegarão. Há, ainda, casos em que o migrante monta uma empresa de venda de maquinários ou de insumos agrícolas e ao mesmo tempo realiza uma atividade paralela de venda de terra; às vezes, essa última torna-se mais lucrativa do que a primeira. Não são raras as situações de grilagem de terras envolvendo essa parcela de empreendedores capitalistas.

A terra é o fator que o migrante sulista visualiza como o mais importante na sua decisão de deslocar-se para o sul do Piauí. Migra para poder ter acesso à propriedade ou conquistar mais terra que, segundo avalia, permite a manutenção da sobrevivência ou, principalmente, a possibilidade de acumular capital dedicando-se à atividade agrícola. Mas a terra representa também uma mercadoria que pode se valorizar ao longo dos anos, seja deixando-a improdutiva esperando que a região se torne mais conhecida e incorpore mais infra-estrutura, seja implementando melhoramentos necessários à produção de outras mercadorias, como as commodities agrícolas. Tais características possibilitam elevar a valorização das terras. Os depoimentos a seguir são reveladores desse processo:

"Eu tinha o suficiente para viver lá no Sul, só que já para as próximas gerações, que são os netos, pois os meus filhos já não tinham condições de comprar terras pros netos lá"

(Anildo Schroreder, gaúcho de Santa Rosa-RS e morador em Nova Santa Rosa. Entrevista concedida em setembro de 2003).

"Nós queríamos um futuro melhor, porque lá no Sul também tá difícil, lá também tem que trabalhar muito, tem que lutar. A gente tem também os filhos 
e queremos dar um futuro melhor para eles. A gente era empregada onde morávamos. Aqui a gente já é autônomo, consegue trabalhar para conseguir uma coisa melhor.”

(Bernadete Renger, gaúcha de Santo Ângelo, moradora em Nova Santa Rosa. Entrevista concedida em setembro de 2003).

"A gente observou o seguinte, deveríamos ter um pouquinho mais de aspiração para obter uma área maior do que a nossa lá no Rio Grande do Sul. Eu já não tava lá tão esmagado, eu tinha 70 hectares de terra, já era considerado bom, mas pra quem quer mexer na agricultura de grãos era inviável. E lá acontecia o seguinte nós tava no esquema que era o seguinte: tinha muitas famílias com muito poder aquisitivo, então nós estávamos supervalorizando as nossas áreas. A gente então pensou que era melhor sair, nós passamos para quem tá lá crescer e nós crescermos também em outro lugar. Nem todos tinha esse espírito de aventura, eu graças a Deus, deus me deu esse espírito, foi o que me trouxe até aqui."

(Valdemar Kretschmer, gaúcho de Horizontina, morador em Nova Santa Rosa. Entrevista concedida em setembro de 2003).

Nos depoimentos acima se observa que a migração dos descendentes dos antigos colonos europeus se confunde com a busca de novas terras, possibilitando que as próximas gerações tenham acesso à propriedade. Mas também a migração representa a esperança de acumulação do capital, materializada na metamorfose da terra em mercadoria. Essa mobilidade paralela de gente e de capital pelas fronteiras agrícolas do Brasil é o que permite associar no imaginário do piauiense dos cerrados, ou de outros grupos das regiões de agricultura moderna, a imagem do sulista àquela de um empresário que carrega consigo todo o aparato das relações capitalistas, no que se refere às formas de apropriação da terra, das relações de trabalho, do uso das técnicas, da organização do espaço de produção etc.

Duas questões fundamentais colocam a propriedade da terra como um importante fator de transferência do migrante sulista para os cerrados piauienses: a sua pretensa disponibilidade e sua potencialidade produtiva em razão das condições naturais (grande insolação e distribuição mais regular das chuvas) e, ainda, a possibilidade de torná-la uma fonte futura de valorização do capital investido. No que se refere a essa última questão, observa-se que tanto o produtor agrícola, quanto o que possui apenas a propriedade da terra, mas não a utiliza produtivamente, ambos vislumbram num futuro próximo obter 
maiores ganhos com a grande valorização que se espera da área. Essa condição é admitida pela projeção que a sub-região dos cerrados nordestinos adquire, como uma promissora produtora de grãos, após a sua inserção numa outra lógica da valorização capitalista. Ocorre que alguns mais capitalizados logram comprar terras em grandes extensões passíveis de colocar uma parte delas no mercado de especulação fundiária; outros, em razão de seu capital limitado, compram apenas o suficiente para o desenvolvimento de uma produção média, para os novos padrões locais ${ }^{71}$. Esses últimos também mantêm a perspectiva de que suas terras possam rapidamente apresentar uma ascensão no preço.

A grande disponibilidade de terra que se acredita existir no sul do Piauí é outro motivador de mobilização dessa população. Nesse caso, a área de saída do migrante é tida como um lugar onde a terra já não se acha disponível para um determinado segmento da população - pequenos e médios proprietários. Busca-se, então, no Piauí, a terra que garantirá a materialização do trabalho de sua família e de gerações futuras. A execução desse projeto nem sempre é bem sucedida; muitos acabam apostando todas as suas economias no projeto de tornar-se donos de terra e grandes produtores agrícolas no Piauí, mas os riscos colocados para uma nova fronteira, às vezes, não permitem que alguns deles consigam atingir tal condição. Os que fracassam, nesse processo, são jogados à exclusão, vivendo nas mesmas condições dos camponeses locais que perderam suas terras por conta do agronegócio, e também se avolumam nas periferias das cidades. Ocorre ainda deles retornarem ao primeiro lugar de origem, no Sul do Brasil, ou partirem para novas áreas inseridas também recentemente na lógica de produção agrícola moderna. Esses que seguem cumprirão as mesmas etapas pelas quais passaram em um momento imediatamente anterior. A imagem do migrante sulista de sucesso para contrapor aos sujeitos sociais que ele encontrará na fronteira apresenta a sua outra face - freqüentemente ocultada, porque é útil ao capital -, das histórias de sacrifício que se abatem sobre aqueles que fraquejam nessa trajetória. Esse processo da não-simultaneidade interna manifestada na mobilidade do trabalho é apontado por Gaudemar (1977: 24):

\footnotetext{
${ }^{71}$ Para que um produtor modernizado consiga se estabelecer nos cerrados piauienses calculase que seja necessário possuir, no mínimo, 500 hectares de terra.
} 
"Face a imagem idílica mantida pelos discursos patronais governamentais - e seus semelhantes teóricos, os modelos neoclássicos -, imagem de uma mobilidade ao mesmo tempo desejada pelos trabalhadores, que lhes traria vantagens pessoais, e desejáveis para o bem-estar coletivo e crescimento, ergue-se então a realidade de uma mobilidade suportada, provocando fluxos de homens apenas ao ritmo das contracções ou expansões do capital; quantos desenraizamentos freqüentemente dolorosos, senão sempre dramáticos, quantos sinais de um progresso ilusório que modela a paisagem social e humana apenas à imagem desumana da polarização capitalista do espaço".

O depoimento que segue, de um dos primeiros sulistas desembarcados no Piauí, em 1985, o qual presenciou a construção dessa fronteira desde seus primeiros passos, traz-nos as seguintes revelações a respeito da seleção produzida pela agricultura moderna junto aos migrantes gaúchos da agrovila de Nova Santa Rosa:

“(..) Isso é uma coisa natural, acho que em dois ou três anos, pelo conhecimento que a gente tem, a grande parte dessas famílias que vieram com a Cotrirosa não vão suportar, não vão conseguir permanecer aqui. O cerrado te limita, não adianta tu plantar 200 hectares porque não sobrevive com 200 hectares, acaba comendo o que tu plantou. Então, não adianta tem que ser uma área maior e aí vai começar a ter restrições, porque eles fizeram lotes de 200 a 300 hectares, certamente parte desse pessoal vai começar a descer para o vale, ele vai virar mini ou micro produtor. Lá em cima da serra vai haver uma seleção natural, os maiores vão engolir os menores"

(Olívio Fonseca, gaúcho de Caxias do Sul, morador em Bom Jesus. Entrevista concedida em setembro de 2003).

As palavras acima nos esclarecem quem verdadeiramente consegue se tornar produtor agrícola modernizado nas novas áreas de agricultura capitalista, os que possuem capital suficiente para adquirir grandes extensões de terra e maquinários modernos. Aquele migrante sulista de posse de menos recursos financeiros que sonha em assegurar a propriedade da terra numa nova fronteira agrícola, utilizando apenas o trabalho seu e o da família, nem sempre consegue concretizar o sonho da promoção social. Em muitos casos ele é obrigado a seguir adiante, buscando assegurar um lote de terra. Nos 
cerrados piauienses, os sulistas que estão ali em condições precarizadas viveram antes tentativas semelhantes de se firmarem como produtores agrícolas em outras regiões, na maioria, projetos mal sucedidos. Os cerrados piauienses se revelam como mais uma esperança para esses trabalhadores, mas o percurso de ocupação daquelas terras se mostra pouco inclusivo também para esse grupo de migrantes. Estes que sobram, os "fracassados" como são denominados pelos outros do próprio grupo que se firmaram como produtores agrícolas, vivem em condições de mobilidade, semelhantes às de outros migrantes brasileiros andarilhos, conhecidos como "trecheiros", freqüentemente indesejados nas cidades do agronegócio do centro-sul (Póvoa Neto, 1997). Ou seja, deslocam-se pelo território nacional quase sem destino em busca de uma ocupação cada vez mais rara. Nas novas fronteiras agrícolas esses personagens estão presentes também entre os sulistas mobilizados, mesmo contrariando os que vêem essa migração freqüentemente como a de vencedores. A modernização, nesse sentido, encarrega-se de fazer uma seleção social daqueles aptos a oferecerem respostas mais imediatas ao processo de acumulação do capital. Aos perdedores resta a alternativa de tornarem-se trabalhadores a procura de trabalho (Martins, 1998), mesmo que a procura se realize pelas formas da precarização. 


\section{4 - OS CERRADOS PIAUIENSES E A SUA NOVA LÓgICA DE REPRODUÇÃO CAPITALISTA}

Compreender o espaço nacional brasileiro em suas múltiplas configurações (sociais, culturais, econômicas, espaciais, naturais etc.) requer um exercício de conhecer suas partes e as especificidades que elas apresentam. Definir esse recorte, portanto, torna-se fundamental, pois pode-se, através dele, chegar às manifestações particulares dos lugares e, ao mesmo tempo, desvendar aquelas que são conduzidas por um movimento exterior, global, mas que interfere na organização sócio-espacial local.

Tenta-se aqui focar o olhar sobre uma das partes do território brasileiro, o sul do Piauí, pertencente à unidade geográfica dos cerrados nordestinos. Tal sub-região participa, nas últimas três décadas, do processo de aceleração da modernização capitalista, cujas manifestações explícitas aparecem sobre a área agrícola, que se altera diante da incorporação de elementos da técnica e da ciência, e sobre a área urbana local, que ganha novas formas e funcionalidades a partir da instalação de produtores e de empresas do setor de agronegócio. Esses novos atores articulam novos cenários em detrimento ou com a anulação das organizações anteriormente existentes.

A recente chegada de grupos econômicos hegemônicos e a mobilização de agricultores empreendedores capitalistas confirmam aquela sub-região dos cerrados nordestinos, pelas novas formas de acumulação, como integrante da lógica global de reprodução do capital. Participa, nesse caso, com a produção de mercadorias agrícolas destinadas aos grandes mercados consumidores brasileiro e do mundo.

Propõe-se, portanto, nesse capítulo, entender de que maneira os cerrados piauienses se inserem nesse contexto de modernização e as alterações produzidas na organização daquele espaço.

\section{1 - As características da expansão da agricultura capitalista nos cerrados piauienses}

Nos anos 1980, e principalmente nos anos 1990, o fluxo migratório dos grupos apontados para as sub-regiões de Barreiras e Balsas também está 
acontecendo para o sul do Piauí. O impulso visando aos processos de modernização contemporânea, no entanto, dá-se de maneira mais comedida, somente adquirindo expressividade, no volume de migrantes e na instalação de empresas, de meados da década de 1990 em diante.

Apesar de constituir-se mais recentemente como área de ocupação da agricultura moderna, o sul do Piauí é parte do mesmo eixo de expansão dos grupos econômicos, os quais se orientaram inicialmente para as bordas sul (Barreiras) e noroeste (Balsas), logo chegando à borda leste dos cerrados nordestinos, onde se encontra o sul do Piauí. As formas de apropriação das terras sul-piauienses pelos agentes do agronegócio em muito se assemelham às adotadas no oeste da Bahia e no sul do Maranhão. Coincide, por exemplo, com a chegada dos primeiros grupos econômicos ao Piauí, nos anos 1970, a implementação de políticas governamentais naquele estado tais como: ampliação das linhas de créditos agrícolas do FINOR (Fundos de Investimentos do Nordeste), do Banco do Nordeste e do Brasil; a implantação ou melhoramento da infra-estrutura viária, de telecomunicações e de energia elétrica; além da grande disponibilidade de terras devolutas apropriadas indevidamente ou a preços muito reduzidos, o que permitiu a transferência de grandes extensões de terras de platôs para o poder de empresas e produtores agrícolas individuais. As terras dos platôs eram as que mais interessavam a tais grupos, porque, dentre outras coisas, possibilitavam o uso mecanizado das terras planas.

Os mecanismos de incentivos econômicos se fortaleceram na década de 1990, com a promessa de implantação do PRODECER, o que depois não se confirmou. Havia também as perspectivas previstas para a construção de corredores viários de exportação destinados ao escoamento da produção dessa sub-região dos cerrados aos grandes portos do Nordeste, especialmente ao complexo portuário de Itaqui/Ponta da Madeira, em São Luís-MA. Os diversos governos piauienses também se empenharam em "vender" a imagem de um Piauí que estava esperando pelos empreendedores capitalistas; para tanto, disponibilizava-se incentivos fiscais e programas de aquisição de terras nos cerrados.

Efetivamente na década de 1990, especialmente após a sua segunda metade, chegam a alguns municípios do sul do Piauí levas de migrantes 
sulistas e de empresas associadas ao agronegócio. A partir desse momento se desencadearam transformações importantes no perfil técnico, econômico, social, cultural e espacial do sul do Piauí.

A aceleração dos processos de modernização nos cerrados piauienses coloca em contradição formas emergidas do novo contexto de reprodução capitalista e as formas que permanecem de um outro momento dessa reprodução. Tais movimentos não simultâneos saltam aos olhos já no primeiro instante em que se chega à área de pesquisa. Depara-se com a construção e a concepção de elementos de tempos diferentes, percebidos distintamente quando se visualiza a organização do urbano ou do rural, desse e de outro momento da história do sul do Piauí. As formas espaciais de outrora, construídas pelos piauienses do passado, cuja geração atual de alguma maneira continua reproduzindo, baseia-se em um tempo muito mais regido pela racionalidade camponesa do que pelo mundo da mercadoria, embora as leis do mercado também ordenassem a vida local. As relações assentadas pela mediação do dinheiro não representavam, entretanto, a forma dominante. Em outras palavras, o tempo de reprodução da vida nos cerrados piauienses, conduzido especialmente pela população camponesa local, obedece, em grande medida, ao ritmo da natureza. Prevalece ainda, nesse universo, à lógica do trabalho concreto, destinado à manutenção da vida, sem passar necessariamente por mecanismos homogeneizadores do processo de produção de mercadorias.

No lugar desse tempo surge um outro que se impõe nos últimos anos e que busca homogeneizar os processos a partir da tutela do dinheiro; é o tempo de agora que deixa sua marca no espaço pela aceleração das transformações. Ele escapa ao controle dos piauienses, ao menos de uma parcela deles, pois é regido por grupos econômicos que impõem a racionalidade do trabalho abstrato. São as empresas associadas às agroindústrias e às famílias migrantes, que chegam sintonizadas com o tempo do capital, mesmo que estas últimas outrora tenham convivido, em sua região de origem, também com a lógica do tempo da natureza. Estão contaminadas (como elas próprias dizem) com o "espírito" de "empreendedores capitalistas", são os agentes de reprodução do valor para o capital; apropriam-se da lógica do tempo abstrato, visando ampliar sua riqueza material. Aqui 0 tempo 
da natureza é passível de ser controlado ou, ao menos, pode se usar dos aparatos disponíveis pelo avanço do capital (a tecnologia) para controlar certas "intempéries" do meio natural. Também estão em sintonia com o mundo organizado, pelo tempo acelerado do capital, permitindo, dentre outras coisas, estabelecer comunicação simultânea com vastos lugares do mundo possibilitando, com isso, avaliar os preços de suas mercadorias no mercado financeiro global. "Aqui nós calculamos diariamente o preço da nossa soja pelo o que é estipulado na Bolsa de Chicago", como me narrava um migrante modernizado, a respeito de sua sintonia com o mundo globalizado. Essa ampliação da modernização pelos aparatos da técnica coloca a população sulista como o principal agente econômico na condução da homogeneização dos processos capitalistas nos cerrados piauienses. A imposição desse novo estilo de vida ditado pelo mundo da mercadoria exclui uma ampla parcela da população local, cujo apego às formas residuais é uma tentativa de manter sua existência mesmo que os símbolos e as coerções materiais da modernidade coloquem obstáculos quase intransponíveis para outras experiências de organizações sociais.

A modernização contemporânea trouxe, nesse sentido, importantes alterações no espaço e nas formas de produção da agricultura sul-piauiense. Tem-se a pecuária extensiva e a agricultura camponesa que conduziam a vida econômica local, e que atualmente continuam existindo, porém é a agricultura modernizada com a produção para as grandes empresas processadoras e para o mercado externo que ganha larga vantagem no processo de concorrência. Nessa nova fase da agricultura piauiense o destaque fica para a soja, que teve uma expansão expressiva naquele estado nos últimos dez anos, inversamente ao que ocorreu com o arroz cuja produção ficou praticamente estagnada ou teve redução (gráfico 09). 


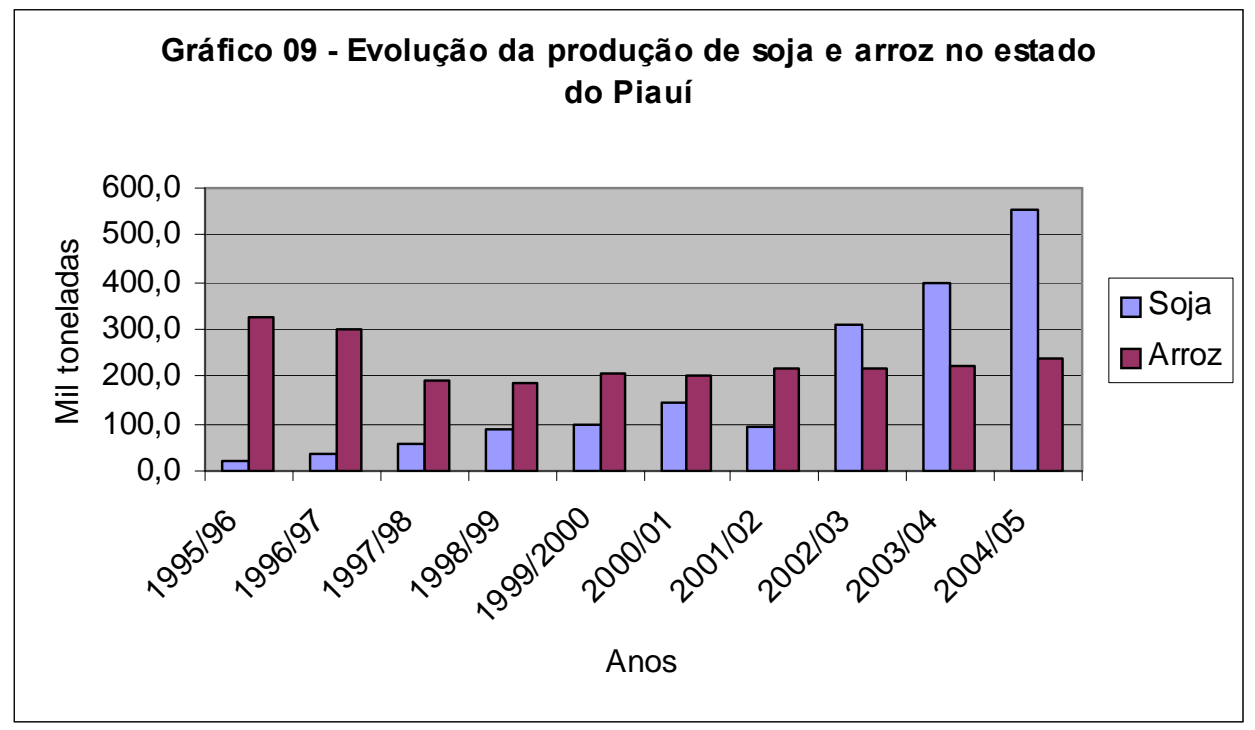

Fonte: Conab - Série Histórica de Produção - Safras 1995/96 a 2004/05.

Quando se analisa a produção agrícola dos dois principais municípios dos cerrados piauienses em grãos, dada a posição adquirida nos últimos anos por conta da expansão do agronegócio na sub-região, percebe-se que a soja torna-se a cultura com ampla predominância sobre as demais, superando em um curto intervalo de tempo o arroz, que até recentemente representava a mais importante cultura daqueles municípios (gráfico 10), sendo que abastecia o mercado local e regional. O salto na produção de soja nos municípios em questão ocorre principalmente a partir de 2002 e se justifica pelo fato de que naquele ano a Bunge Alimentos iniciava a instalação de uma fábrica de esmagamento dessa oleaginosa em Uruçuí, o que desencadeou uma expansão da produção sojicultora no sul do Piauí para atender à demanda da empresa. A chegada da Bunge nos cerrados piauienses consolidou as mudanças que já vinham se projetando no perfil agrícola daquela área, as quais apontavam para a substituição da cultura do arroz pela da soja. 


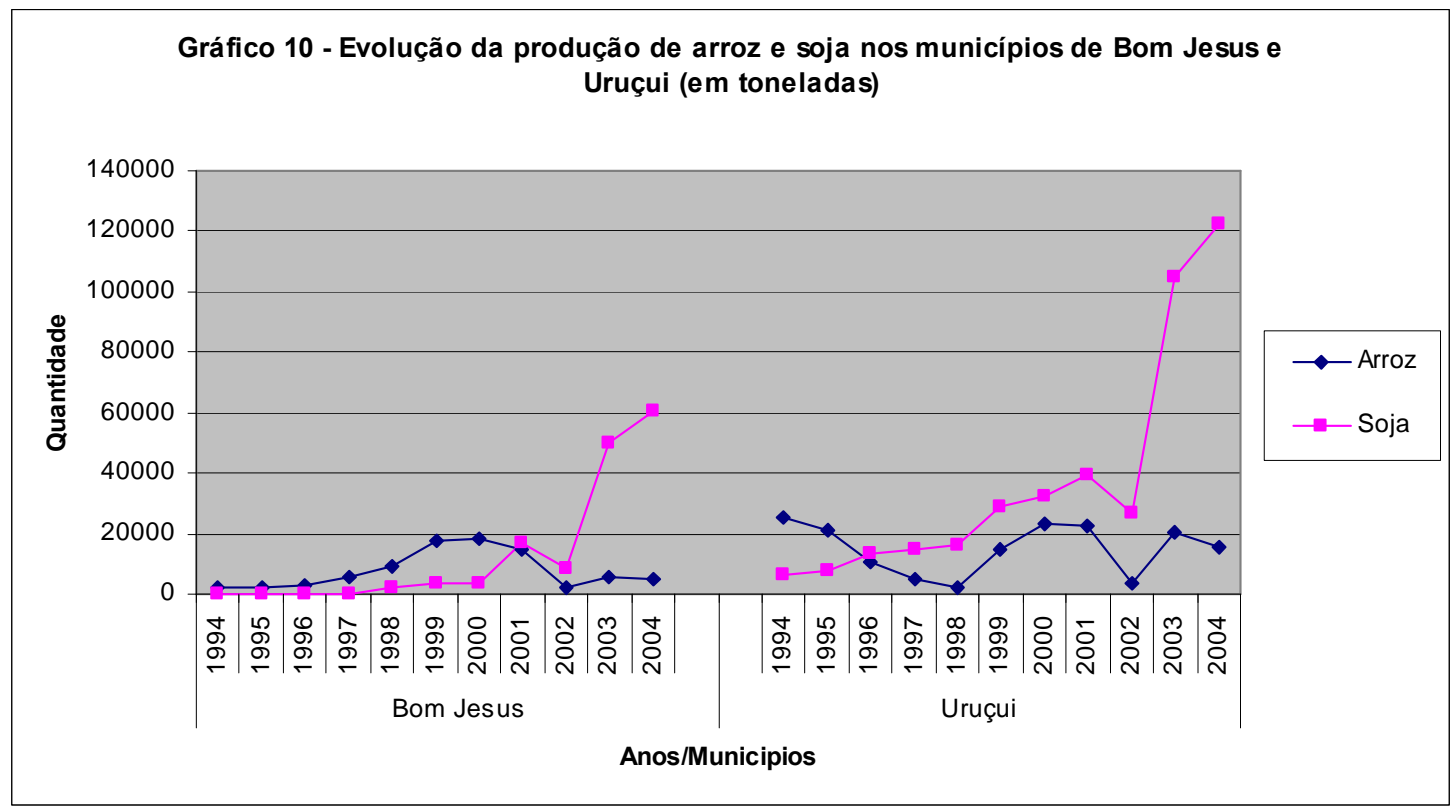

Fonte: IBGE - Produção Agrícola Municipal (PAM), 1994-2004.

A perspectiva de aumento na produção de mercadorias agrícolas, sobretudo a soja, e, ao mesmo tempo, de acesso a terras a baixos preços, desencadeou a instalação de empresas na sub-região, quase inexistentes em outros momentos. As relações de trabalho também se alteraram com a instalação do agronegócio. Nos últimos anos, houve acréscimo nos cerrados piauienses do trabalho assalariado e de novas profissões que atendem às demandas surgidas do movimento da agricultura capitalista moderna. O que se verifica, entretanto, é uma grande variação no regime de emprego e desemprego de trabalhadores naqueles municípios dos cerrados piauienses mais atingidos pelo movimento do agronegócio. O gráfico 11 nos mostra a dinâmica de ocupação ocorrida nos quatro municípios da sub-região, aqueles que receberam as maiores influências de empreendimentos agrícolas modernos em suas economias: Uruçuí, Bom Jesus, Ribeiro Gonçalves e Baixa Grande do Ribeiro. 


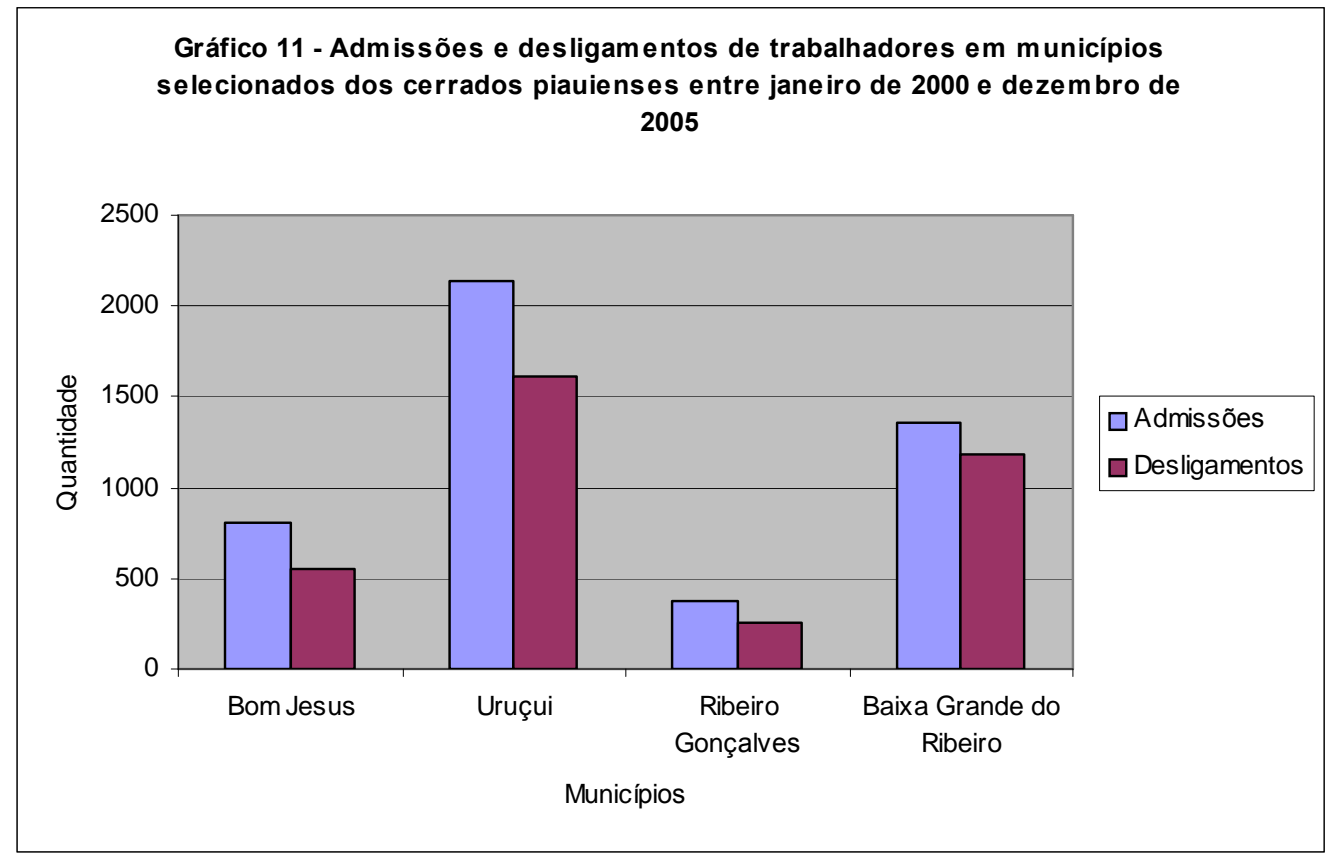

Fonte: Cadastro Geral de Empregados e Desempregados (CAGED) - Ministério do Trabalho e Emprego, 2005.

Os dados confirmam o aumento de ocupações nos principais municípios atingidos pela expansão agropecuária no sul do Piauí. Apesar do surgimento de algumas ocupações com mais especializações (tratorista, agrônomo, operador de máquinas de beneficiamento de produtos agrícolas etc), o que ainda predomina em tais municípios é o trabalho temporário com pouca ou nenhuma especialização (trabalhadores volantes da agricultura, vendedor de comércio varejista etc.). Esse último segmento de trabalhadores foi o que apresentou maior número de contratações, mas também o de desligamentos, isso vale tanto para as profissões exercidas no urbano (vendedores do comércio varejista, pedreiros etc.) quanto no rural (trabalhadores volantes). Essa flutuação no tempo de ocupação contribui para a permanência de uma instabilidade econômica dessa população, cuja remuneração ocorre apenas por um curto período do ano. Além disso, são trabalhadores freqüentemente contratados sem o devido respeito às leis trabalhistas vigentes, permanecendo na informalidade, o que os torna mais vulneráveis diante do novo contexto de vida a que se submetem, de moradores do urbano, portanto, sem a possibilidade de obter a sobrevivência senão através da venda de sua força de trabalho. 
O município de Uruçuí desponta como o mais dinâmico no mercado de trabalho local confirmando sua importância na condução do processo de modernização agrícola do sul do Piauí. A consolidação do agronegócio no município, que além da Bunge Alimentos recebeu outras empresas prestadoras de serviços e de comércio agrícola, não se reverteu numa situação muito diferenciada dos demais municípios quanto à expansão e ao recuo das contratações. Embora apresente um balanço positivo no número de pessoas ocupadas, os desligamentos são bastante elevados, o que reduz as possibilidades da formação de uma economia mais sustentável, sem contar que existem outros efeitos negativos resultantes desse processo: impacto ambiental; transferência de recursos públicos para o setor privado, através de incentivos fiscais; degradação do espaço urbano, que cresce desordenadamente etc. A presença de uma grande empresa como a Bunge Alimentos contribuiu, sem dúvida, para ampliação das ocupações, mas é necessário relativizar o seu papel como fomentador de emprego. As ocupações criadas após a sua instalação em Uruçuí ocorreram, sobretudo, de maneira indireta, decorrentes de outras empresas que chegaram ao município, principalmente associadas ao setor de comércio e de serviços. Presume-se, nesse sentido, que a empresa motivou a instalação de novos estabelecimentos na sub-região (gráfico 12), mas isso não se reverteu em aumento substancial de postos de trabalho mais duradouros. A própria Bunge funciona mantendo uma situação de sazonalidade no seu quadro de funcionários. Nos meses de safra, quando aumenta a necessidade de mão-de-obra, emprega diretamente cerca de 200 pessoas, mas no período de entresafra a fábrica reduz sensivelmente esse número para aproximadamente 80 funcionários, permanecendo, especialmente, os empregados de manutenção e administração. Apenas esses trabalhadores pertencem ao quadro de efetivos da empresa, são os que possuem mão-de-obra especializada e freqüentemente foram remanejados de unidades produtivas do grupo em outros estados brasileiros. Tal fato indica uma crise de realização da mercadoria força de trabalho, porque as empresas das novas áreas de produção agrícola moderna já chegam com um alto grau de mecanização. 


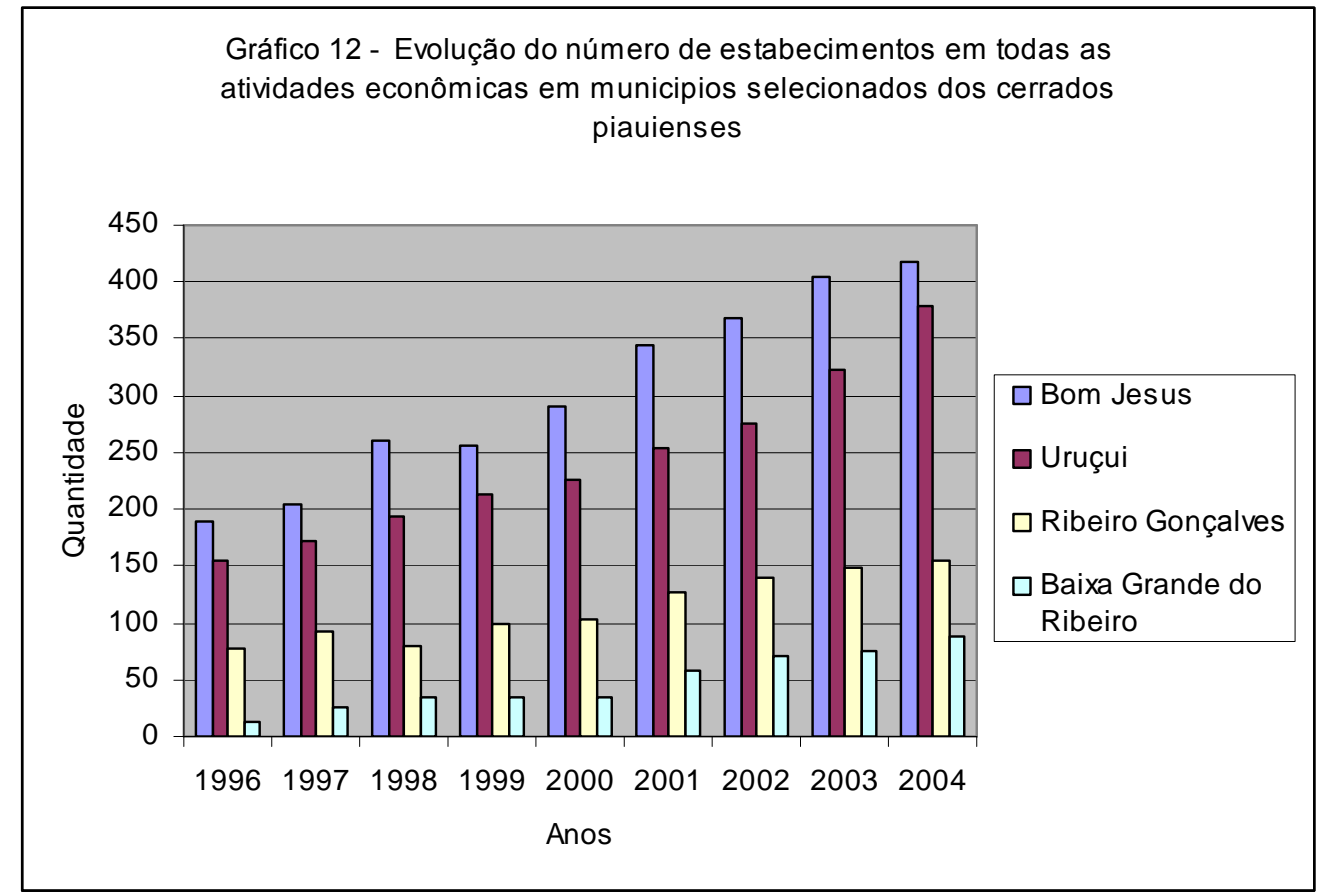

Fonte: IBGE - Cadastro Central de Empresas, 1996-2004.

Os números do gráfico acima indicam uma expansão considerável de estabelecimentos naqueles municípios do sul do Piauí onde o agronegócio se fez mais presente. Tal acréscimo se deve à instalação de empresas de diversas características e ramos de atuação: fazendas de produção de grãos, lojas de material da construção civil, lojas de magazines, padarias, mercearias, restaurantes, lojas de maquinários, escritórios de prestação de serviços agropecuários, hotéis etc. Esses estabelecimentos apresentam limitações, entretanto, para ocupar a força de trabalho local. Embora ocorra uma maior movimentação de capital nas fazendas modernas de produção de grãos e nas lojas de maquinários, o que predomina, freqüentemente, são pequenos negócios cuja capacidade de empregar a mão-de-obra é ainda mais reduzida; freqüentemente, ocupam a força de trabalho familiar ou, às vezes, contratam alguns poucos funcionários. Essa restrição em gerar postos de trabalho coloca em xeque o discurso presente no sul do Piauí de que o investimento na agricultura moderna representaria a solução para o problema do emprego nessa área. As expectativas que a população local depositou nesse processo tornam-se, dessa maneira, atenuadas ou mesmo frustradas. Além disso, as contratações, como os dados estatísticos apontam, ocorrem 
sazonalmente, o que não soluciona a carência econômica daquela população. Pelo contrário, a modernização contemporânea que se mostrou como uma promessa de inclusão, suscita uma nova situação de crise, na medida em que desarticula os meios de produção dos camponeses da sub-região. Agora, estes trabalhadores costumam deixar suas roças para empregar-se em serviços temporários cujas tarefas são, prioritariamente, limpar manualmente as áreas recém desmatadas que serão semeadas com arroz, milho e, principalmente, soja. Abandonam temporariamente suas propriedades ou posses em períodos importantes da produção familiar, coincidindo com as épocas de desmate, plantio ou colheita, seguindo para as fazendas agropecuárias. O trabalho assalariado se converte em desarticulação das formas de vida desse universo camponês, enfraquecendo as formas de relações mediadas pela natureza e fortalecendo as mediadas pelo dinheiro. Diante desse quadro, muitas famílias largam definitivamente suas unidades produtoras, deslocando-se para 0 urbano, onde ficam à espera de algum recrutamento das empresas ou dos produtores agrícolas modernos. Para lograr uma ocupação que Ihes renda de dez a quinze reais diários, esses trabalhadores postam-se numa situação de quase mendicância por uma vaga nas fazendas de produção de grãos. Os poucos selecionados permanecem durante dias longe da família, exercendo tarefas extenuantes, e vivem em condições mais degradantes do que em momentos anteriores à chegada da modernização agrícola contemporânea.

\section{2 - Os cerrados piauienses e as iniciativas governamentais direcionadas à aceleração dos processos de modernização}

As mudanças que se verificam hoje no Piauí, particularmente nos cerrados do sul do estado, têm suas origens entre as décadas de 1960 e 1970, particularmente nessa última, quando ocorreram investimentos públicos federais visando impulsionar a modernização do setor agropecuário de várias regiões brasileiras. No Nordeste, sobretudo, a preocupação era a de proporcionar condições para que a economia de áreas do interior da região, tradicionalmente de baixo rendimento produtivo, pudesse integrar-se ao mercado nacional, ou mesmo internacional, a partir das exportações de 
produtos primários: frutas, carne bovina etc. Foram criados, nesse sentido, dentre outros programas, o POLONORDESTE, o Projeto Sertanejo e o Programa de Irrigação do Nordeste. Além disso, disponibilizou-se linhas de créditos da SUDENE e do Banco do Nordeste para projetos de reflorestamento e melhoramento da pecuária.

No caso piauiense, dos recursos direcionados pelo POLONORDESTE para a modernização agropecuária, beneficiou-se principalmente a camada de médios e grandes proprietários rurais. Isso não ocorreu de maneira distinta na aplicação de recursos públicos no restante do Nordeste, o que confirma a intenção do programa de atingir especialmente esse segmento de produtores. De fato, buscava-se orientar os recursos para aqueles proprietários de estabelecimentos que se imaginava em condições de acelerar a construção de um mercado nacional mais homogêneo. Observa-se, assim, que não somente as diretrizes do POLONORDESTE seguiam essas orientações, mas também as de programas executados em outras regiões, como o do POLOCENTRO, no Centro-Oeste. Dessa maneira, as estratégias visavam dirigir recursos para aqueles agricultores que pudessem responder mais rapidamente ao propósito definido pelo Estado brasileiro naquele momento, qual seja, o de aumentar as exportações a partir da produção agropecuária, garantindo, com isso, 0 equilíbrio da balança comercial, além de responder à pressão crescente por alimento decorrente do processo de urbanização em curso no país.

Outros programas governamentais destinados ao Nordeste apresentaram objetivos semelhantes aos do POLONORDESTE. É o caso, por exemplo, dos Fundos de Investimentos do Nordeste (FINOR), administrados pela SUDENE, fundos que se derivaram do Mecanismo 34/18 criado em 1961, a partir do I Plano Diretor da própria SUDENE, cujo objetivo era disponibilizar investimentos públicos ao setor privado do Nordeste, através de incentivos fiscais. Uma parcela significativa dos recursos desse sistema (que passou posteriormente a se denominar FINOR) destinava-se prioritariamente para 0 setor rural, com destaque para a pecuária nordestina, cujo funcionamento ocorria com técnicas convencionais, como as de criar 0 gado solto alimentando-se de pastagens naturais. Dos projetos agropecuários aprovados pela SUDENE, entre os anos de 1965 e 1976, a pecuária bovina foi a que 
obteve maior participação (64,4\% do total dos projetos) no destino dos recursos (Carneiro, et al., 1984). Isso comprova que a preocupação das políticas públicas direcionadas ao campo brasileiro, naquele momento, era a de acelerar os processos de modernização, partindo dessa atividade econômica, particularmente no Nordeste.

A atuação do FINOR Agropecuário, no Piauí, concentrou-se, em grande medida, no centro-sul do estado, com destaque para a área de cerrados, do que fazendeiros locais e/ou de outras unidades da federação se beneficiaram, obtendo financiamentos públicos facilitados através de linhas de créditos de bancos oficiais (Banco do Brasil e do Nordeste). Tais recursos teriam teoricamente como destino o melhoramento da capacidade produtiva das tradicionais fazendas de gado (aquisição e melhoramento do rebanho, plantação de pastagens etc.), projetos de produção agrícola, sobretudo de arroz, e, em menor volume, a formação de áreas de extrativismo. Os reflexos econômicos positivos nesses setores, porém, não foram substanciais, haja vista que poucos são, atualmente, os pecuaristas do estado que criam seus rebanhos em bases mais modernas.

Complementando o FINOR, foram disponibilizados também para os cerrados piauienses recursos advindos dos Fundos de Investimentos Setoriais (FISET) que, prioritariamente, destinavam-se a projetos de reflorestamento

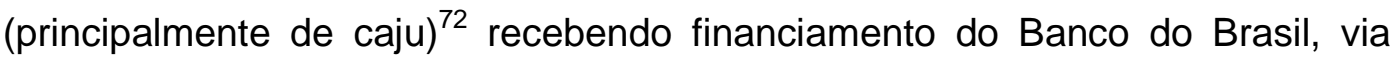
Instituto Brasileiro de Desenvolvimento Florestal (IBDF). A proposta era garantir que médios e pequenos empreendedores rurais pudessem desenvolver projetos geradores de renda aliados a preservação ambiental. O que se verificou, todavia, foi o direcionamento dos recursos e do acesso à terra para apenas algumas empresas, principalmente de outros estados, as quais obtinham aprovação de vários projetos seus em detrimento de uma participação mais numerosa de produtores locais. A concentração de recursos financeiros e de terra advindos do FISET foi verificada nos municípios de

72 O sul do Piauí foi, nos anos 1970 e 1980, a principal área do Brasil que abrigou projetos de reflorestamento com caju. Cerca de $108.871,52$ hectares, sendo que $88,90 \%$ correspondiam a áreas dos cerrados piauienses, destinaram-se aos projetos financiados para tal fim. Somente nos municípios de Uruçuí e Ribeiro Gonçalves as terras destinadas a reflorestamento com cultura de caju ocuparam uma extensão de 76.719,56 hectares. Essas áreas, em sua quase totalidade, foram transferidas posteriormente para projetos agropecuários modernos (Moraes, 2000: 210). 
Ribeiro Gonçalves e Uruçuí, conforme nos relata Monteiro (2002: 117), no que se refere aos efeitos dos projetos de reflorestamento instalados em tais municípios e quem foi favorecido:

"O IBDF estabelece o limite de, aproximadamente, 100 hectares de terra para incentivar, via FISET, projetos de (re)florestamento. No entanto, os laudos de vistoria de acompanhamento do IBAMA (instituição que substitui o IBDF, a partir de 1989), provam a existência de diversos grupos de empresas, que possuem áreas superiores ao limite fixado. Por exemplo, o grupo empresarial que administra os projetos instalados na Fazenda dos Gaúchos possui 32 projetos, totalizando 4.448,26 hectares de terras; o grupo empresarial que administra os projetos instalados na Fazenda Mafisa com 57 projetos para um total de 9.913,79 hectares de terra apropriada (ambos no município de Ribeiro Gonçalves); o grupo empresarial que administra os projetos da Fazenda Nova ou Bonita, em Uruçui, possui 58 projetos e uma área incorporada de 20.109 hectares. Comparando-se o total de área dos estabelecimentos dos municípios de Ribeiro Gonçalves (457.539 hectares) e Uruçui (361.654 hectares), em 1985, com a área total dos 243 projetos financiados pelo FISET, que chega a 60.692,11 hectares, registra-se que essa última representa a ocupação de $7,4 \%$ do território dos municípios. Este dado pode ser considerado aparentemente inexpressivo, mas quando se constata que três únicos grupos empresariais, como acima citados, possuem 34.471,05 hectares, representando $56,8 \%$, do total dos projetos incentivados, evidencia-se o nível de concentração na aquisição de terras nos referidos municípios".

Esses projetos de reflorestamento no Piauí tiveram o mesmo fim dos de pecuária melhorada ou de outros associados à agricultura comercial; quase todos eles foram abandonados restando apenas em algumas áreas vestígios de grandes plantações de cajueiros, hoje substituídas por lavouras modernas. Os sucessivos governos piauienses contribuíram sobremaneira para a difusão de tais projetos no sul do estado e foram coniventes com o agravamento da concentração da estrutura fundiária na região, pois permitiram, através da Companhia do Desenvolvimento do Piauí (COMDEPI), o repasse de grandes extensões de terras públicas às empresas interessadas em aquisição de áreas para a execução de pretensos projetos agropecuários e de reflorestamento ${ }^{73}$. A

\footnotetext{
${ }^{73}$ As empresas que adquiriram terras são dos mais variados ramos de atividade, demonstrando que o interesse não era tanto o de desenvolver produtivamente projetos agropecuários, mas o de acesso a recursos públicos e, ao mesmo tempo, tomar posse de grandes extensões de terras. Em Ribeiro Gonçalves (Guimarães, 1988, apud Moraes, 2000) foram identificadas 30 empresas com suas respectivas áreas apropriadas no município, o que confirma a afirmação acima. Segue a relação de tais empresas e as extensões adquiridas em hectares: "CONFIANÇA Agro-Industrial (25.000); José Gomes da Silva (12.000), Agro-pecuária Guimarães S/A (25.000); CREMAQ - Reflorestamento e Agropecuária Ltda. (25.000);
} 
participação da COMDEPI nas negociações de terras públicas repassadas às empresas representava uma estratégia do governo piauiense para despertar interesse dos investidores do agronegócio pelos cerrados e, ao mesmo tempo, garantir um mercado de terras na região. A transferência do patrimônio fundiário público para o setor privado não favoreceu ao estado, entretanto, obter ganhos financeiros com a venda das terras, pois os preços cobrados nas transações possuíam mais um caráter "simbólico", haja vista que a intenção era fomentar o fluxo de capital para um estado que se pretendia inserir no curso da modernização retardatária. Mesmo que para isso precisasse abrir mão de suas riquezas.

Como se vê, esses programas não atingiram o objetivo que se propunham, qual seja, o de destinar recursos para a sustentação do desenvolvimento agropecuário e florestal das regiões semi-árida e dos cerrados do Piauí. Em contrapartida, o que se presenciou foi um aumento substancial da concentração fundiária no estado, viabilizada também pela apropriação ilegal de terras públicas, sendo a região sul a mais atingida (Bandeira, 1993).

Transzero - Transportadora de Veículos Ltda. (24.736); MAFISA - Agropecuária Ltda. (24.984); Serviços Agropecuários Ltda. (24.984); Alimentos Básicos do Piauí S/A - ABAPISA (25.000); Bastos Locadora Ltda. (22.553); PAISAGRO Ltda. (24.829); Serviços Agropecuários Ltda. (24.993); O.N.V. Participação e Administração S/A (05.961); O.N.V Agropastoril Ltda (05.929); Economisa Administradora de Imóveis Ltda (05.952); Economisa Reflorestamento Ltda. (05.959); Antonio José Siqueira (02.990); Estrela - Engenharia Ltda. (20.059); BRASIDIESEL S/A Comercial e Importadora (12.000); Expresso Caxiense S/A (12.000); Automecânica S/A Importação e Comércio (12.000); Eletro Tecnodiesel S/A (12.000); EMAFLOR - Empreendimentos Agroflorestais Ltda. (12.000); Oscar Tadeu Medeiros (1.571); Osacra Dantas Medeiros (1.918); ELETRON - Produtos Químicos Ltda. (14.087); TAOMINA Agro Florestal Ltda. (23.580); Felipe José da Silva (387.28); Neuza Maria de Souza (103.50); Gilmar Carvalho de Souza (109.40); Izidoro Pereira dos Santos (103.90); Josias Lino Marques (73.50)" (In: Moraes, 2000: 208). 


\section{3 - A ocupação recente dos gerais sul-piauiense: a apropriação irregular da terra comunitária}

Os cerrados piauienses situam-se numa zona fisiográfica de transição, entre o semi-árido e a Amazônia. Pertencem à área nuclear dos cerrados brasileiros, na porção da bacia Maranhão-Piauí (Ab'Sáber, 2003). Os chapadões com vales encaixados, recobertos de vegetação de cerrado, campo cerrado, brejos e mata ciliar (Sales, 1997) compõem as principais características paisagísticas dessa sub-região dos cerrados nordestinos. Historicamente, os vales foram os preferidos pela população piauiense, principalmente porque foram os cursos d'água que conduziram o povoamento daquelas terras. Desde o início de sua inserção no processo de modernização capitalista, a partir da colonização portuguesa ou mesmo antes com as populações indígenas, a produção da vida dos piauienses dos cerrados passa a ser fundamentalmente nos vales próximos aos cursos d'água, seja para desenvolver atividades agrícolas, de criação de gado ou de extrativismo, seja para formação das aglomerações urbanas. Os vales e a água constituíram-se como as referências mais importantes para a construção daquele território.

Os cursos d'água são apontados por Prado Jr. (1965: 58) como o que verdadeiramente influenciou na ocupação das terras dos sertões nordestinos. Conforme aparece nas suas palavras:

“(...) Os fatores naturais, em particular a ocorrência da água, tão preciosa neste território semi-árido, tem aí um papel relevante. É sobretudo na margem dos poucos rios perenes que se condensa a vida humana. No São Francisco, nos rios do Piauí, e do alto Maranhão. Intercalam estas regiões mais favorecidas extensos desertos a que somente as vias de comunicação emprestam algumas vidas. (...) As 'cacimbas' (poços d'água) congregam quase todo o resto do povoamento; assim, onde o lençol de águas subterrâneas é mais permanente e resiste mais às secas prolongadas, bem como onde ele é mais acessível aos processos rudimentares de que dispõe a primitiva e miserável população local, o povoamento se adensa. 'Olho d'água' é uma designação que aparece freqüentemente na toponímia do interior nordestino: a atração do líquido é evidente."

Pereira D'Alencastro (1857: 5) também fez menção à importância da d'água para a ocupação do Piauí, particularmente no que se refere ao 
desenvolvimento da pecuária, importante atividade na formação daquele território:

"As fazendas de gado vacum estão situadas sobretudo nas fraldas de vários olhos d'água que delas nascem. Para que no sertão uma fazenda mereça o nome de boa, deve ser primeiro bem provida de água, porque sendo o Piauí sujeito a secas, como todos ao altos sertões do Brasil, as fazendas com faltas de água são as primeiras que ficam despovoadas de seus gados."

A pouca ocorrência de água na superfície dos platôs planos e a sua precária comunicação com os núcleos urbanos que se formavam, instalados freqüentemente próximos aos principais rios, impediam que os piauienses habitassem esses domínios, exceto nos vales intercalados, os baixões, onde havia água, e em muitos deles moravam posseiros que sobreviviam de suas pequenas roças e do que poderiam extrair dos gerais.

Os domínios dos platôs sempre representaram para os moradores dos cerrados piauienses lugares de usos complementares aos da vazante; eram pouco aproveitados para fins agrícolas ou de moradia, mas muito para a prática de uso comum. Caracterizavam-se como importantes reservas naturais onde se soltava o gado da população local (de fazendeiros a camponeses), que aproveitava das pastagens naturais em determinadas épocas do ano, ou serviam de lugar de caça e de extrativismo de lenha e de frutos e plantas medicinais (Alves, 2001). Por constituir-se predominantemente de terras devolutas, não cercadas, portanto, essas áreas formavam extensos descampados de matas de cerrados. No contexto social local, as terras dos gerais significavam um lugar de vital importância para a manutenção do modo de vida das comunidades camponesas. Seu equilíbrio se mantinha pelo uso privado das roças, na vazante, e o que se podia aproveitar, sem qualquer impedimento, dos recursos existentes nos gerais. A forma pela qual a população camponesa dos cerrados piauienses articulava o uso dos baixões e dos gerais (chapadas) para garantir a manutenção da vida é evidenciada por Moraes (2000: 267), conforme nos relata: 
“(...) os solos da chapada só passaram a ser propícios à prática da agricultura com as tecnologias geradas pela Revolução Verde. Esse terreno tampouco era tido pelos camponeses como lugar de agricultura. No entanto, a agricultura camponesa no ambiente dos cerrados, tomada como parte de um sistema produtivo em sentido mais amplo, supõe uma articulação essencial entre baixões e chapadas. Nesse sentido, se o baixão é o lugar do assentamento, da propriedade, da morada, da delimitação dos parentes e vizinhos, da nucleação em pequenas comunidades, a chapada é o mundo a perder de vista, terra de ninguém e, portanto, de todos - cujas funções são nem por isso menos básicas para a economia camponesa. Nesse sentido, era, no sistema antigo, segundo os camponeses, o lugar do uso em comum da terra voluntária, sem cercamento." (grifos da autora)

A constituição dos gerais como terra de uso comum nasce da própria estrutura da ocupação portuguesa nos sertões nordestinos e, em particular, nos do Piauí. No Brasil esse sistema de uso da terra é resíduo do que havia na Europa continental e Inglaterra até o século XVIII, quando as últimas terras comunais vão sendo cercadas, desaparecendo quase completamente o direito costumeiro que permanecia desde o antigo regime feudal (Thompson, 1998). Portugal foi uma das últimas nações a perder os traços do feudalismo. Nesse sentido, reproduziu certos mecanismos desse sistema em terras brasileiras (Campos, 2000), na tentativa de modernizar, num processo pautado pela não simultaneidade. No caso piauiense, costumava-se deixar áreas livres entre as concessões de sesmarias, o que possibilitava a prática do uso comunitário nessas terras. Em 1850, quando se implanta a Lei das Terras, o Estado brasileiro torna-se dono de parte das terras que não foram registradas onde havia as sesmarias, surgindo desse processo as áreas devolutas, o que permitiu a manutenção ou a ampliação do direito de uso em comum de vastas áreas do país.

A maneira como se distribuía a concessão das terras no Piauí e o uso que se fazia do terreno livre deixado entre as sesmarias é relatada por um viajante que passou pelo Piauí no século XVIII, conforme expõe o texto abaixo: 
"As terras do Piauí soam repartidas aos moradores em sesmarias ou datas de três léguas, cuja cultura consiste na criação de gados, mas vacum que cavalar. Cada uma das sesmarias forma uma fazenda, deixando-se uma légua para a divisão de uma e outra fazenda. Na dita légua entram igualmente os vizinhos a procurar os seus gados, sem contudo poderem nela levantar casas e currais" ${ }^{\text {"74 }}$.

A modernização contemporânea, com a instalação de novos agentes econômicos nos cerrados piauienses, a partir na década de 1970 em diante, significou uma importante metamorfose no uso das terras dos gerais: de espaço de uso tradicional explorado comunitariamente pelas necessidades concretas de vida da população local em espaço privado destinado à agricultura capitalista moderna.

A recente ocupação dos platôs se define pelo uso essencialmente capitalista. As terras se tornam em si mercadorias - apesar de que, desde a Lei de Terras, já o eram, juridicamente -, colocadas no mercado imobiliário apresentando uma rápida valorização. Poucas delas são efetivamente cercadas, mas a configuração da propriedade particular aparece nitidamente delimitada; o que era antes espaço de uso comunitário em áreas abertas sofreu metamorfose: às vezes, são as lavouras de soja, milho, algodão ou solos desnudos em imensos descampados que explicitam os limites da propriedade.

$\mathrm{Na}$ nova organização da área dos gerais, a paisagem anterior desaparece rapidamente, no lugar onde havia vegetação original com grande variedade de espécies da flora e da fauna, instalam-se elementos da agricultura moderna. Os sistemas técnicos tornam-se os principais elementos presentes e auxiliam o ritmo da produção de mercadorias agrícolas: pivôs de irrigação; máquinas agrícolas fiscalizadas por satélites; grandes galpões capazes de armazenar milhares de toneladas de grãos monitorados sob rígido controle de qualidade; escritórios controlando em tempo real o preço das commodities nas principais bolsas mundiais; unidades de recebimento de grãos das grandes empresas instaladas em pontos estratégicos, e próximo delas um movimento intenso de caminhões despejando ou retirando produtos para as fábricas esmagadoras ou para os portos exportadores. Esse movimento

\footnotetext{
74 "Roteiro do Piaui a Goiás." (Anônimo), Revista do Instituto Histórico e Geográfico Brasileiro, Tomo LXII, parte I, 1900, p.79. In: Mott, L.R.B. - (1985: 51).
} 
torna-se esclarecedor da insurgência de novos tempos vividos nos gerais dos cerrados piauienses.

A apropriação privada e a presença das técnicas modernas nos gerais reduziram significativamente as áreas de uso comunitário, cada vez menos disponíveis. Esse fato se reflete em toda a organização espacial e da vida da população local, inclusive no que diz respeito à ocupação dos vales. Como afirmamos anteriormente, os moradores dos cerrados se aproveitavam dos gerais para, em determinadas épocas do ano, ali mandar suas reses, a fim de usufruírem as pastagens naturais; agora essa prática reduziu significativamente. Sem a disponibilidade dos gerais, os criadores se utilizam cada vez mais das terras do vale para a atividade pecuária, avançando sobre as de agricultura, principalmente a camponesa.

O depoimento que segue de um camponês, morador em terras de baixões do município de Bom Jesus, é revelador da mudança do direito costumeiro suprimido com a instalação de novos agentes econômicos, os quais passam a ocupar áreas onde antes havia um outro uso:

"Não pode mais isso de colocar o gado na serra. Agora a lei (sic) garante o seguinte: que o gado tem que ser no cercado, tem que se criar preso para não entrá nos projeto lá da serra."

(Sr. Pedro, morador na posse Pirajá, no município de Bom Jesus, julho de 2005).

Outras formas de uso dos gerais também decresceram nos últimos anos, limitando a ação dos camponeses. As matas nativas possuidoras de variados tipos de frutos, de plantas medicinais e de mel desaparecem numa velocidade alucinante diante do desmatamento provocado pelas lavouras modernas, as quais não deixam quaisquer vestígios de vegetação original. $O$ mesmo ocorre com a caça e a madeira. A nova impossibilidade de usar os gerais para complementar sua alimentação ou para retirar de lá matéria-prima destinada a algumas atividades econômicas, como no caso, dentre outras, da madeira para produção de móveis, produziu impactos sócio-econômicos importantes em todo conjunto da população camponesa local, revelando as novas potencialidades de crise que se anunciam geradas pela modernização contemporânea. 
As mudanças de uso chegam juntas com a expropriação dos camponeses moradores nos baixões, a maioria deles posseiros habitantes dessas áreas desde tempos imemoriais. Há registros na história piauiense da presença deles nos baixões desde o início da colonização portuguesa, cujas terras constituiriam o Piauí. Tais personagens foram aproveitados para tomar frente do processo de conquista de território para a coroa portuguesa, em áreas que antes pertenciam a distintas nações indígenas praticamente exterminadas pelos novos povoadores.

Os baixões representavam para essa população excluída, a possibilidade de se manter com a sua família, produzindo apenas o necessário para sua sobrevivência e, eventualmente, comercializando o excedente nas feiras livres ou vendendo para algum comerciante das cidades locais. $O$ isolamento desses domínios tornava-se tanto um impedimento para o uso capitalista que mesmo os tradicionais fazendeiros piauienses pouco se interessavam por esses domínios, o que permitiu que levas de posseiros permanecessem nessas áreas, reproduzindo um modo de vida camponês até recentemente; em alguns casos, continuam, mas espremidos e pressionados pelos agentes do agronegócio.

O longo período de uso dessas áreas sedimentou um conhecimento por parte dos camponeses da dinâmica geográfica de tais domínios. Nesse sentido, a maior umidade se comparada com as terras dos gerais produziu o conhecimento e o manejo dos recursos ali existentes e as formas de seu aproveitamento, numa estreita relação com o tempo da natureza. A presença de dois tipos de terrenos: a vazante (área sedimentar de inundação periódica) e os brejos (formados de solos hidromórficos permanentemente inundáveis) ampliam as possibilidades de uso dos baixões. A vazante é o lugar para o desenvolvimento das roças, que se faz com uso de mão-de-obra familiar e instrumentos com pouco avanço tecnológico. Planta-se nelas quase tudo o que se necessita para a alimentação da família, em sistemas de consorciamento de culturas. Às vezes, as roças dividem o espaço da vazante com as pastagens, sobretudo aquelas destinadas à criação de bovinos, mas também a de caprinos e outros animais de pequeno porte. Os brejos constituem, por conseguinte, um ecossistema específico dentro da vazante, e também são fundamentais para os habitantes dos baixões. Caracterizam-se por terrenos planos encharcados 
onde afloram os lençóis freáticos e recebem água do transbordamento dos rios. Nesse lugar florescem, além de outras espécies, os buritizais (maurítia verifera) muito aproveitados, pois deles se retira o fruto consumido in natura ou em sucos e doces; extraem-se ainda a madeira e as folhas para a construção de casas. Quando o buritizeiro está recém-formado utiliza-se os seus galhos para a produção de uma espécie de fibra, destinada à confecção de utensílios de usos variados (balaios, chapéus, esteiras, tapetis ${ }^{75}$ etc.). Do solo hidromórfico encontrado nos brejos costuma-se retirar a matéria-prima para a elaboração de alguns recipientes, tais como: potes, vasos etc. Como se vê, tanto a vazante quanto os brejos cumprem um relevante papel na manutenção do modo de vida camponês dos cerrados piauienses, principalmente para a população que habita os baixões.

A presença da agricultura moderna vem alterando rapidamente esse quadro. Os camponeses dos baixões foram os primeiros a sofrerem o impacto da ocupação recente, pois no uso privado dos gerais também foram incluídas as terras de fundo de vale que separam os platôs, os baixões. Para a agricultura moderna essas terras não apresentam, neste momento, importância produtiva, mas são utilizadas para atender a legislação ambiental, pois é necessário reservar áreas de preservação permanente ${ }^{76}$. Como o empresário agrícola deseja retirar o máximo de vegetação das áreas nos platôs planos para a produção, sobram, então, os domínios dos baixões para cumprir as determinações legais ambientais.

Ao adquirir uma área de platôs onde existem também áreas de baixões, o empresário ou o especulador imobiliário freqüentemente se posiciona contra a permanência de posseiros na área, requisitando a saída das famílias, seja através da coerção seja tentando convencê-las a receber quantias em dinheiro (normalmente valores quase irrisórios) para deixar livres as terras de ocupação humana.

\footnotetext{
${ }^{75}$ Instrumento de origem indígena utilizado para o escaomento do líquido advindo da massa da mandioca que se destina à fabricação da tapioca.

${ }^{76}$ Pelo artigo 16 da MP no. 2.166-66, de 26 de julho de 2001, é necessário disponibilizar, como reserva legal, $20 \%$ da propriedade rural situada em área de floresta ou outras formas de vegetação nativa localizadas fora do perímetro da Amazônia Legal. No Piauí há um acordo entre governo e proprietário reservando $30 \%$ da propriedade para mata nativa (In: SEMAR$\mathrm{Pl})$.
} 
Nos cerrados piauienses os casos recentes de expulsões de trabalhadores dos seus locais de moradias são incontáveis. Em Bom Jesus, o Sindicato de Trabalhadores Rurais do município recebeu, nos últimos anos, várias denúncias apontando para a expropriação de posseiros, além de verificar a ocorrência de conflitos entre as próprias comunidades moradoras nos baixões, estimulados por especuladores fundiários interessados nas terras dos camponeses. Os documentos contendo registros de depoimentos dos moradores dos baixões no sindicado daquele município indicavam uma acelerada expansão do comércio de terras com o envolvimento de alguns posseiros e de agricultores modernos, produzindo prejuízo para os demais moradores dessas áreas.

Em 2005, havia várias denúncias registradas na documentação do sindicato, a principal delas referia-se a um conflito na Serra do Pirajá, nos municípios de Bom Jesus e Currais, área constituída de platôs e baixões. Uma parte dessas terras, predominantemente de platôs, foi distribuída pelo governo do Piauí para associações de pretensos produtores agrícolas de outros estados, sobretudo do Rio de Janeiro (Interpi, 28/06/2005). A outra parte, localizada nos baixões e também nos gerais, manteve-se sob posse de seus antigos moradores. Algumas famílias posseiras habitantes daquelas terras, entretanto, reclamavam de outras famílias da mesma condição, alegando que estas vendiam posses suas e de outros para empresários da agricultura moderna. Os denunciantes apontavam um grande especulador imobiliário incentivando anonimamente para que alguns posseiros vendessem a parcela que Ihes cabia na posse ou até mesmo ampliasse irregularmente seus domínios sobre as áreas dos demais, o que lhe renderia mais dinheiro. Após o negócio concluído, o dito especulador, além de pressionar os outros também a venderem suas terras, expandia o tamanho da propriedade adquirida a partir da elaboração de documentação fundiária falsificada. Esse fato gerou, no interior daquela comunidade camponesa, desconfianças e divisões no grupo, o que facilitava a ação dos compradores de terra. A expropriação conta, nesse sentido, com o apoio interno dos membros da comunidade, eles próprios mobilizam seus pares para o trabalho, como fica claro no depoimento que se segue: 
"Esses posseiros que o governo deu documento de terra, eles pegaram na parte que tinha na serra e já venderam tudo inclusive aqui do baixão, eles tiraram o arame deles da terra que foi feito projeto no banco, cercada pelo banco (...), pegaram, tiraram o arame, deixaram a terra deles limpa e invadiram as terras de outros. Uns venderam por 60 mil (reais) a propriedade. São mais ou menos 100 familias, só que alguns tão invadindo as terras dos outros para vender para esses empresários que chegam do Paraguai, do Rio de Janeiro, que vem comprar terras aqui. Então, os coitados mais fraquinhos estão sendo enganados por seus próprios companheiros dos baixões. Pode dá um conflito sério aqui entre os próprios pobres".

(Sr. Pedro, morador na posse Pirajá, no município de Bom Jesus. Entrevista concedida em julho de 2005).

Constam vários outros exemplos de expropriação de posseiros nos cerrados piauienses. Não são estranhas à população local, por exemplo, histórias de violência praticadas por fazendeiros, grileiros, autoridades locais contra os posseiros, num primeiro momento as principais vítimas do movimento de apropriação das terras devolutas dos cerrados. Esses camponeses são expulsos de suas terras, na maioria das vezes através da coerção física, ou por métodos questionáveis de transferências de famílias camponesas para outros lugares, inclusive com a colaboração do poder público.

No município de Currais, desmembrado recentemente de Bom Jesus por conta de seu fortalecimento político adquirido pela instalação de agricultores e algumas empresas agropecuárias modernas, foram registradas outras expulsões de posseiros de suas terras. É o caso, por exemplo, da fazenda Pitombeiras, em que famílias habitantes da área tiveram que abandonar suas posses sob a coerção de forças contratadas por fazendeiros, inclusive com o envolvimento de representantes do poder político local, conforme aparece no depoimento abaixo:

"Aqui têm vários casos de posseiros que perderam suas terras expulsados pela polícia. Só expulsa os pobres. Aqui teve o caso da fazenda Santa Tereza de 123 mil hectares, tiraram os pobres da roça e toraram o arame, queimaram a roça e o pobre ficou no prejuízo. A fazenda Pitombeiras era de uns pobres coitados que os rico tomou. O ex-prefeito de Currais tomou a propriedade, jogou o pessoal fora tacando o gadinho deles. Tá aqui o pessoal sofrendo, todo dia esse pessoal vai ao sindicato pedi socorro e não tem quem toma providência." 
(Sr. Pedro, morador na posse Pirajá, no município de Bom Jesus. Entrevista concedida em julho de 2005).

O caso mais emblemático, no entanto, envolvendo a expulsão de posseiros de áreas de baixões, o que demonstra a face perversa da sociedade moderna, ocorreu com a instalação de uma grande empresa estrangeira no Vale do Gurguéia, em terras dos municípios de Guadalupe, Cristino Castro e Colônia do Gurguéia. Trata-se da Anna Purna Ltda, conglomerado econômico de produção de alimentos orgânicos e ervas aromáticas de origem indiana, consorciado com grupos de capital especulativo de vários outros países. Essa empresa adquiriu no sul do Piauí uma propriedade de aproximadamente cinqüenta mil hectares para construir uma base de produção agrícola no Brasil, a partir de preceitos filosóficos de alimentos pretensamente saudáveis e de preservação da natureza. Atualmente possui uma moderna fazenda de produção de mel, de ervas e de frutas tropicais no sul do Piauí. Para realizar suas tarefas de manejo extrativo ou agrícola contratam alguns trabalhadores locais. Surpreende, entretanto, o fato de que, durante a permanência na fazenda da empresa, não se permite que tais trabalhadores façam uso de alimentação contendo carne ou derivados bovinos. Além disso, é preciso diariamente, numa determinada hora, a reunião de todos para reverenciarem a divindades hindus, ato que carece de qualquer sentido religioso para aquela população.

Para a sua instalação no cerrados piauienses o referido grupo econômico exigiu a apropriação de áreas que estivessem livres de posseiros. Como é quase impossível encontrar grandes extensões nos cerrados piauienses com essas características tornar-se-ia necessário, então, remover os moradores do local de interesse da empresa. As áreas para formação da fazenda da Anna Purna foram negociadas por um especulador fundiário cearense que havia adquirido grandes extensões de terras no Piauí na década de 1970, aproveitando-se das facilidades de obtenção de créditos públicos para projetos agropecuários ou de reflorestamentos. $O$ interesse, naquele momento, não era desenvolver qualquer projeto (tratava-se apenas de uma ação enganadora para ter acesso a recursos governamentais), mas o de assegurar a posse da terra. Para tanto, o referido especulador autorizou a 
permanência dos antigos moradores ou incentivou outros a se instalarem na área. Essa estratégia foi adotada por vários grileiros dos cerrados piauienses, os quais aproveitaram dos agregados para poder garantir que a terra incorporada não fosse ocupada por outros, mas apenas por aqueles que recebessem a sua autorização.

A possibilidade de obter elevados lucros fundiários caso se efetivasse a transação comercial daquelas terras com a Anna Purna fez com que tal especulador tratasse de remover todos os habitantes da área como recomendava a empresa. Era necessário, então, tirá-los pelo convencimento ou pela coerção. A proposta inicial apresentada aos posseiros habitantes da área era a de pagar valores de aproximadamente nove mil reais pelas benfeitorias existentes; algumas famílias foram convencidas a receber lotes de terras em lugares fora da fazenda ou ainda se mudar para uma agrovila que seria construída especialmente para receber os posseiros, onde eles ganhariam além da casa um lote de cerca de quinze hectares. A maioria aceitou esta última proposta; apenas duas famílias resistiram por mais tempo, conforme depoimento de um dos posseiros, cujos familiares mudaram-se para área a ser vendida a Anna Purna nos anos 1970:

"Olha, os donos daquelas terras antes da instalação da empresa, eles nunca vieram aí, vieram quando foi comprar e agora quando foi vender. Quando ele comprou colocou nóis lá como moradores, ai fiquemo lá trinta e três anos no poder deles, só que ele nunca veio aí não, eu sei que ele era de Fortaleza. Aí apareceram esses indianos querendo comprar aquelas terras, agora, eles colocava que só comprava se tirasse os morador, isso foi em 1999. Aí esse que se dizia dono das terras inventou de tirá nois de lá, né, mas não consiguiu tira, né. Aí inventou uma associação, inventou de dá uma outra fazenda pra nós de 500 hectares, mas tinha que passá por dentro da fazenda dos indianos, aí os indianos não queria. Aí começaro construir agrovila aqui sem consultá nóis, né. Alguns acabaram aceitando rápido e vieram pra cá. Mas, minha família e de outro companheiro não aceitemo logo de cara, porque as casinha aqui na vila é tudo pertinho uma da outra, aí não dá, porque nóis estava acostumado no mato criando nosso bichinhos. Ele mandou dividi as terra aqui. Nóis era 22 família, eles combinaram para dividi a terra em partes iguais onde nóis estamo hoje aqui. Foi que os indiano compraram a propriedade lá deles"

(Rosalvo, posseiro transfrido para a Vila Manoel Dias Branco. Entrevista concedida em janeiro de 2006). 
Para abrigar os posseiros da comunidade Deserto, um dos baixões localizados na área adquirida, foi construída a agrovila, às margens da rodovia BR-135, em Alvorada do Gurguéia, que receberia o nome de "Manoel Dias Branco" (foto 18). Nela os posseiros passam a morar num espaço que apresenta um outro tipo de organização, com casas próximas umas das outras acompanhadas de pequenos quintais, muito distinto da anterior situação onde as áreas de uso produtivo e de exploração comunitária eram mais amplas, possibilitando maior liberdade de ação e aproveitamento dos recursos naturais.

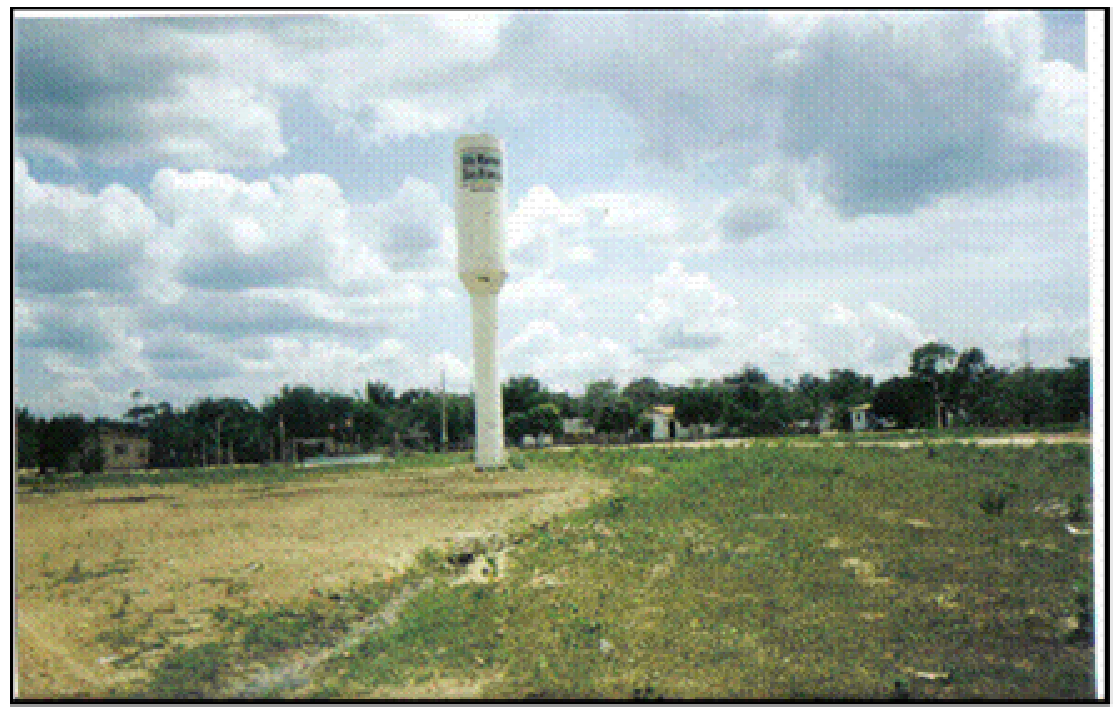

Foto 18 - Agrovila Manoel Dias Branco habitada por antigos posseiros da ärea adquirida pela empresa Anna Purna. Foto do autor. janeiro de 2006 .

A violência mais extrema, entretanto, praticada contra esse grupo ocorreu pela posição intransigente da Anna Purna para que se removessem os restos mortais dos familiares sepultados nas terras adquiridas pela empresa. Pretendia-se, assim, além de evitar contendas judiciais futuras coibir a circulação de posseiros por aquelas terras, os quais são proibidos de visitar seus antigos locais de moradia. O plano da empresa foi executado, pois todos os cemitérios pertencentes das comunidades instaladas na área adquirida foram transferidos. Os restos mortais da comunidade "Deserto" foram transferidos para as proximidades da agrovila (foto 19), mas não houve 
qualquer preocupação em identificar os cadáveres e a quais familiares vivos pertenciam. Muitos dos mortos foram enviados para valas comuns, sepultados sem identificação ou com nomes alterados. Suprime-se, assim, o direito do grupo de prestar cerimônia aos seus familiares mortos, manifestação sagrada que acompanha os seres humanos desde os seus primeiros passos e que 0 processo de modernização capitalista tenta destruir (Mumford, 1961). Essa forma de violência é ainda mais sentida para uma família camponesa cuja religiosidade se faz intensamente presente e representa os principais elementos estruturadores de suas manifestações sócio-culturais.

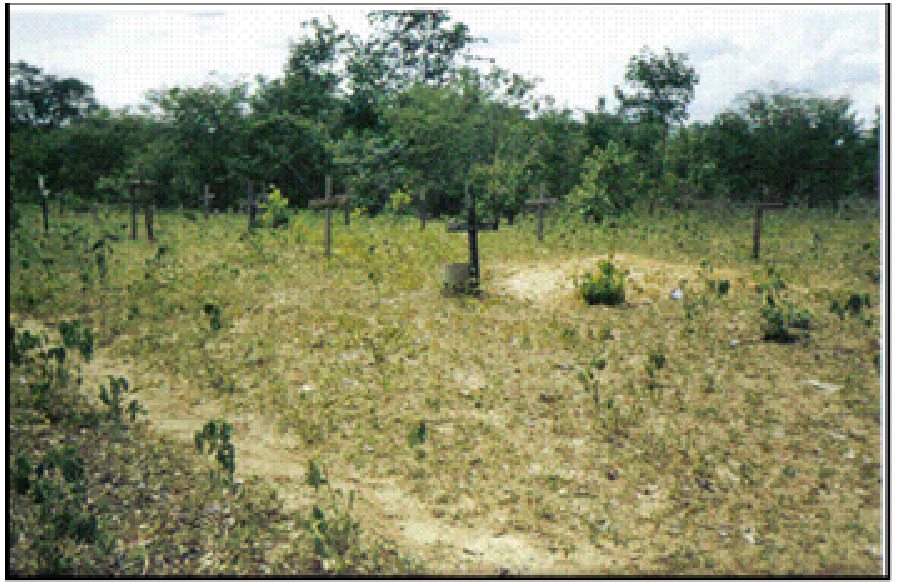

Foto 19 - Cemiterio instalado proximo a agrovila Manoel Dias Branco, com os restos mortais retirados da ares adquirida pela empresa Anna Purna Foto do autor, janeiro de 2006.
"Quando indianos aquelas inventaram de arrancar os morto, aí pegaram uma funerária de Bom Jesus para arrancar os morto. Porque o medo dos indiano era que as pessoa fosse lá acender vela. Quando foi arrancar os coveiro não tava arrancando direito não, arrancava uns dois osso e pronto, dizia que já tinha arrancado tudo, mas era

mentira. Aí trouxeram os osso e enterraram ali, ninguém nem sabe de quem é a cova ali, tá tudo misturado. Nóis entramo na justiça por causa disso, nóis coloquemo um advogado, mas o advogado não presta, eu acho que o advogado foi comprado pelos indianos. Estamos pedindo indenização, porque eles arrancaram sem a nossa autorização, e sem arrancar direito os corpo, deixaram a metade lá. Arrancaram e logo passaram a máquina pra ninguém descobri. Agora nóis não pode nem entra lá, só se for escondido. Foi três cemitério. Tinha muitas familia, tinha do projeto Piauí e muitas outras (...). Eles queria pagar cinco mil reais para todo mundo de indenização, aí nóis não quisemo"

(Rosalvo, posseiro transferido para a Vila Manoel Dias Branco. Entrevista concedida em janeiro de 2006).

Esse episódio é revelador de que o sistema produtor de mercadorias se forma eliminando todas as outras estruturas de organização social préexistentes. Distintos métodos coercitivos serão adotados para que o capital 
possa cumprir as etapas de sua acumulação. Utiliza-se, desse modo, da força do dinheiro para desarticular quem se coloque como impedimento à realização do projeto de expansão das forças capitalistas. No Piauí essa expansão ocorre pela apropriação dos espaços produtivos das comunidades camponesas ou dos do Estado, na maioria das vezes através de mecanismos escusos. São contabilizados, nos últimos anos, incontáveis casos de grilagem nessa região anunciando mais uma dimensão da crise proveniente da modernização contemporânea. O problema fundiário se agravou nos últimos anos nos cerrados piauienses por conta da apropriação privada de maneira ilegal de amplas parcelas de terras devolutas que posteriormente são comercializadas aos que chegam ao Piauí, para aqueles que se dispõem a pagar por elas preços medidos através da especulação. Muitos dos migrantes sulistas que adquiriram terras de grileiros nos cerrados piauienses não conseguem agora proceder à legalização delas, principalmente porque o próprio grileiro vendeu a mesma área para mais de uma pessoa.

\section{4 - O avanço da grilagem nos gerais piauienses}

A grilagem nos cerrados piauienses é atualmente um grave problema, dado o volume de terras apropriadas de maneira ilegal e o surgimento de conflitos agrários envolvendo posseiros, grileiros e produtores agrícolas modernizados. Essa questão, no entanto, tem suas raízes principalmente na década de 1970, quando se instalam as primeiras empresas sustentadas com recursos da SUDENE. Em meados da década de 1970 (conforme relatos da população local, obtidos em trabalhos de campo), era comum a presença de representantes de empresas de outros estados, sobretudo nordestinos, em diligência pelos municípios dos cerrados piauienses à procura de terras para aquisição. Segundo apontam os moradores, quem se dispunha a vendê-las necessitava apenas da apresentação de um simples documento (uma carta, por exemplo) que comprovasse a presença da família na área. A regularização das mesmas era providenciada, posteriormente, pelos advogados das empresas.

Essa prática foi extremamente difundida no sul do Piauí e revela que

uma das estratégias das pretensas empresas empreendedoras naquele 
momento era a de adquirir terras a baixo ou nenhum custo e utilizá-las para receber os benefícios governamentais, como os do FINOR agropecuário e do FISET. Isso porque somente poderiam ter acesso aos recursos de tais programas aquelas empresas que se apresentassem como detentoras de terra na área onde fossem executados os projetos agropecuários ou de reflorestamentos. Verificou-se, mais tarde, que poucas delas levaram adiante os projetos apresentados às instituições financiadoras públicas. Além de acesso ao dinheiro público as empresas ou os empreendedores individuais aproveitaram também para a apropriação de grandes extensões de áreas devolutas. Nasce desse processo uma das ramificações da grilagem que se fortalece nos anos posteriores.

Naquela etapa de ocupação do sul do Piauí predominam grupos econômicos nordestinos, mas também aparecem os primeiros empreendimentos sulistas nos cerrados nordestinos. Ambos amparados por políticas governamentais. Segundo Diniz (1984: 18);

"Os grupos econômicos são o segundo agente de penetração do capital [no Nordeste Centro-Ocidental Brasileiro]. Diferenciam-se dos agricultores individuais pelo suporte governamental de que dispõem, bem como pela violência de sua penetração. São, sobretudo, grupos nordestinos, mormente pernambucanos, amparados pelos incentivos da SUDENE e que tendem a ocupar e cercar grandes áreas. Aparecem também grupos extra-regionais, ligados ao sistema financeiro, como em Canto do Buriti, ou às vezes, acompanhando a migração individual, como em São Desidério, aonde começam a chegar grupos empresariais do Paraná”.

Superada a fase dos projetos agropecuários e de reflorestamentos, ocorridos principalmente entre as décadas de 1970 e 80, inicia-se a fase de mobilização dos agricultores sulistas interessados no Piauí, atraídos pela possibilidade de adquirir terras a preços menores aos de outras regiões do Brasil. Há registros dos primeiros sulistas no final dos anos 1970, mas, como vimos, as maiores levas ocorrem somente em meados dos anos 90. Nesse momento, expande-se o comércio fundiário nos municípios detentores de terras platôs, sobretudo os localizados na Serra do Uruçuí. Apesar da existência de propriedades abaixo de 1.000 hectares, o que predomina, entretanto, são extensões acima desse tamanho indicando o perfil do novo proprietário de terras que se instala no sul do Piauí. A pesquisa de Monteiro (2002) confirma 
(amparada em documentação fundiária dos cartórios das comarcas de Uruçuí e Ribeiro Gonçalves, em 2001) que a maioria dos negócios envolvendo aquisição de terras nesses dois municípios e mais no de Baixa Grande do Ribeiro (emancipado de Ribeiro Gonçalves em 1994) acontecia para os estratos de áreas acima de 1.000 hectares, conforme nos aponta a autora para o caso de baixa Grande do Ribeiro:

"Ao longo de sete anos (1994 a 2000), são realizados, em Baixa Grande do Ribeiro, 122 negócios, o que corresponde à incorporação de 363.520,19 hectares. Chama atenção a predominância do número de negócios no estrato de área de 1.000 a menor de 10.000 hectares, com 44 transações (36,1\% do total), apropriando-se de uma área de 137.469, 35 hectares, o que vale $37,8 \%$ da área total negociada. Enquanto isso, o estrato de 10.000 e mais hectares conta com 13 transações, equivalendo a 10,6\% dos negócios, mas, incorporando 207.763, 6 hectares, ou seja, 57,1\% da área total transacionada. Isto significa dizer que os dois maiores estratos de área 1.000 a menor de 10.000 hectares e 10.000 e mais hectares são responsáveis por 95\% do total da área transacionada, ou seja, o grande número de negócios é realizado, apropriando-se de vastas extensões de terras de Baixa Grande do Ribeiro".

A apropriação privada dessas terras foi coordenada no governo piauiense responsável pelos programas de distribuição de lotes destinados a empresas e agricultores individualizados, geralmente de outros estados (Moraes, 2000). O objetivo do governo, em diferentes administrações, era o de fazer da região dos cerrados um celeiro de produção de grãos, principalmente nos platôs planos, onde havia grandes extensões, constituídas, predominantemente, de terras devolutas. A presença de terras nessas condições era uma marca importante na caracterização da estrutura fundiária dos municípios dos cerrados piauienses (tabela 08).

O processo de ocupação de tais áreas foi extremamente conturbado, revertendo numa ampla transferência, de maneira ilícita, de terras de uso comunitário para as mãos de particulares, gerando descontrole na jurisdição da propriedade da terra. É possível encontrar atualmente nos cerrados piauienses documentação fundiária atestando dois ou mais proprietários de uma mesma área. Ou seja, sobreposição de proprietários de posse de documentos cujas terras não existem, ou com documentação no "segundo ou terceiro andar", como costumam relatar os técnicos que investigam os problemas fundiários do sul do Piauí. Essa situação advém da construção de uma ampla rede de 
grileiros com experiências em apropriação de terras públicas concebida em outras partes do país. A presença de falsificadores fundiários nos cerrados piauienses resulta da ramificação dessa rede, que se instala no Piauí disposta a usurpar um importante patrimônio de terras devolutas existentes nos municípios do sul do estado, conforme nos confirmam os números da tabela a seguir.

\begin{tabular}{|c|c|c|c|}
\hline Município & $\begin{array}{l}\text { Área Total do } \\
\text { Município (ha) }\end{array}$ & $\begin{array}{c}\text { Área Devoluta } \\
\text { (ha) }\end{array}$ & $\begin{array}{c}\text { Porcentagem } \\
\text { (\%) }\end{array}$ \\
\hline $\begin{array}{c}\text { Baixa Grande do } \\
\text { Ribeiro }\end{array}$ & $796.773,97$ & $615.638,97$ & 77,26 \\
\hline Bom Jesus & $568.558,13$ & $355.516,03$ & 62,29 \\
\hline Gilbués & $347.517,94$ & $143.287,04$ & 41,23 \\
\hline Ribeiro Gonçalves & $391.813,43$ & $192.424,03$ & 49,11 \\
\hline Santa Filomena & $536.890,12$ & $272.133,52$ & 50,68 \\
\hline Uruçuí & $854.231,83$ & $416.781,53$ & 48,79 \\
\hline Total do estado & $25.131 .152,16$ & $10.561 .277,79$ & 42,02 \\
\hline
\end{tabular}

Fonte: INCRA, 2003.

De acordo com Asselin (1982) acredita-se que a "escola" da grilagem tenha nascido no oeste do Paraná, quando da ocupação daquela região. De lá expandiu-se para outras regiões mais ao norte do Brasil. É provável que a apropriação das terras da Amazônia Ocidental tenha acontecido com a participação de membros dessa "escola".

A grilagem de terras no Brasil se transformou em uma verdadeira indústria, adquirindo a sofisticação de seus métodos à medida que novas terras do território nacional foram sendo incorporadas ao capital. Monbeig (1984: 144/5) faz referência a essa "indústria" na área de expansão do café no Oeste paulista, como nos esclarece o texto que segue: 
"[...] os falsários [grileiros] deram provas de imaginação e habilidades diabólicas: buscaram folhas de papel timbrado com as armas imperiais, imitaram escritas fora de uso, descolaram velhos selos, amareleceram propositalmente seus documentos, arrancaram páginas dos registros dos tabeliães. Implantavam-se à pressa cafeeiros de vinte ou trinta anos nas clareiras das florestas. Transportavam-se partes destacadas de casas velhas, que eram guarnecidas com móveis antigos, para criar o ambiente adequado e simular uma antiga ocupação do solo. Era preciso também premunir-se contra os adversários, pois muitas vezes dois ou três indivíduos moviam demandas ao mesmo território, com algumas variantes na delimitação. Nesse caso, era indispensável cair nas boas graças do juiz de direito e dos agrimessores. E, por fim, era o assassinato uma solução levada em conta".

A grilagem nos domínios dos platôs piauienses ganha notoriedade na década de 1970, mas se intensifica em meados dos anos 80 em diante, quando essa sub-região dos cerrados nordestinos começa a despertar maior interesse do capital agropecuário. Os mecanismos de apropriação irregular da propriedade da terra são variados, embora exista uma "metodologia" semelhante nas ações. Os agentes econômicos que primeiro se instalam no Piauí nessa nova fase da modernização procuravam tomar posse de grandes extensões de terras, freqüentemente, estabelecendo alianças com grupos locais ou de estados vizinhos, particularmente de municípios baianos na divisa com o sul do Piauí. Suspeita-se, também, de servidores do Instituto de Terras do Piauí (INTERPI) e da Companhia de Desenvolvimento do Piauí (COMDEPI), os quais auxiliavam nos esquemas de corrupção, facilitando a titulação de terras devolutas para grupos privados.

A participação dos cartórios dos municípios dos cerrados piauienses, entretanto, foi fundamental para a ampliação e a efetivação da rede de grilagem, acobertados, em muitos casos, por juízes de comarcas. Numa diligência fiscalizatória nos cartórios de notas e registros de imóveis do sul do Piauí, em 2001, a Corregedoria do Estado encontrou graves irregularidades em quase todos eles, sobretudo no que se refere à transferência de terras devolutas para um seleto grupo de grileiros. Em Bom Jesus, um dos municípios onde a participação de grileiros foi intensa nos últimos anos, a referida fiscalização detectou que em apenas uma das falsificações de documentos fundiários houve apropriação privada de aproximadamente 97.000 hectares de terras devolutas, referendada sob a anuência da juíza daquela comarca, conforme nos deixa claro o documento da Corregedoria: 
"No Cartório do $2^{\circ}$. Ofício de Bom Jesus, encontramos o processo no. 43/75, de Demarcação e Divisão Amigável, lavrada às fls. 99, do livro no. 30, de 15/07/1989, em que, 'num acerto' entre os condôminos Ademar Queiroz Diógenes, Manoel Holanda Saldanha e José Soares de Holanda, apoiada em planta e memorial descritivo, firmado pelo agrimensor Elizio Pereira da Cruz, em desacordo com a lei, foram transformados, 860 (oitocentos e sessenta) braças e 539,00,00 (quinhentos e trinta e nove) hectares, em 97.170.00,00 (noventa e sete mil e cento e setenta) hectares. (...) Nesse ilegal e danoso procedimento demarcatório e divisório, infelizmente homologado, em 30/06/89, pela Juíza Maria do Rosário de Fátima Matos (...)."

(Correição extraordinária nos cartórios da comarca de Santa Filomena - PI Corregedoria Geral da Justiça do Estado do Piauí. Abril de 2001).

O referido documento de fiscalização apontava outras situações em que ocorreu uma intensa ação de grileiros nos cerrados piauienses, com comprovação de que funcionários ou responsáveis pelos cartórios pertenciam à rede de falsários de terras devolutas. Apenas nos cartórios de Santa Filomena, Gilbués e Bertolínia foram encontradas pelos corregedores, em meses concentrados de 1996 e de 1997, vinte e três (23) matrículas de imóveis e muitas averbações executadas irregularmente, envolvendo transferência de terras devolutas para o poder de grileiros, sendo o principal deles João Emídio de Sousa, procurador na compra de terras para a empresa Solo Sagrado Colonizadora e Negócios Ltda. Para lograr a usurpação dessas terras, segundo consta no documento, tal grileiro contava com o auxílio de escreventes dos cartórios daquelas comarcas. Alguns dos registros expedidos nessas transações expõem falhas grosseiras, as quais indicam que os falsários pouco se preocupavam com possíveis revelações acerca das alterações nos registros da documentação, como fica evidente no referido relatório:

"para a melhor doutrina, é considerado terras devolutas aquelas que não estejam incorporadas ao domínio privado, como acontece em muitos casos vistos, pois as próprias escrituras estão dizendo que os imóveis não registrados no registro imobiliário. Exemplos das muitas escrituras lavradas nos Cartórios do $1^{\circ}$. Ofício de Gilbués e de Bertolínia, referidas nestes autos, item IV, números 6 a 17 e 19 a 22. Nas referidas escrituras constam o número de registro eclesiástico, contudo, na época das referidas transações já vigorava a lei dos registros públicos, assim, antes de vender, seus proprietários deviam ter cuidado de registrar seus títulos, se é que possuíam. A regra está no artigo 227 da lei. Estranhamos que se possa, no Registro Eclesiástico, em duas folhas - 
$89 \mathrm{v} / 90$ - de um mesmo livro, e sob o mesmo no. - 454 - ter sido registrados o elevado número de proprietários e de propriedades, umas sem divisão e outras divididas e demarcadas. Só vendo pra crer!!!. (...) As retificações do registro imobiliário são feitas respeitando o disposto no artigo 213, da lei de registros públicos. Deve ser através de processo judicial, quando altera a descrição da área, sendo nula as re-ratificações procedidas em cartório, descritas no item IV, números 1, 6 a 17. No número 18 há um outro caso de alterar registro anterior, na descrição da área, sem o processo legal. Em todos eles há uma ilegalidade sobre a ilegalidade, ou seja, falsificaram o que já era falso"

(Correição extraordinária nos cartórios da comarca de Santa Filomena - PI Corregedoria Geral da Justiça do Estado do Piauí. Abril de 2001).

As práticas golpistas apresentadas acima, empreendidas por grileiros profissionais, também são realizadas por indivíduos administradores dos cartórios dos municípios sul-piauienses. A participação comprovada de profissionais falsificadores de documentação pública no cartório de primeiro ofício do município de Gilbués, e em vários outros existentes nos cerrados piauienses, revela o comprometimento desses órgãos com a efetivação da propriedade privada da terra naquela área. Os métodos adotados pelos tabeliães envolvidos na falsificação dos registros fundiários consistiam em lavrar "escrituras públicas de compra e venda de imóveis ou de re-ratificação transformando ínfimos valores em cruzeiros de posse, em extensas áreas territoriais", conforme um dos exemplos que se segue:

"Escritura pública de re-ratificação, lavrada às fls 156, do livro 54, datada de 07/1997, em que o valor primitivo de Cr\$15,00 (quinze cruzeiros) de posse, foi convertido para 26.095,00,00 (vinte e seis mil, noventa e cinco) hectares, tendo como adquirente, João Emídio de Sousa Marques, e transmitentes, Antônio Lopes e outros."

(Correição extraordinária nos cartórios da comarca de Santa Filomena - PI Corregedoria Geral da Justiça do Estado do Piauí. Abril de 2001).

Somente no Cartório do $1^{\circ}$. Ofício de Gilbués foram encontradas trinta e duas (32) escrituras públicas de "re-ratificação", elaboradas entre 1997 e 2001, contendo esse "modus operandi", que totalizavam aproximadamente 258.464 hectares de terras devolutas transferidas ilegalmente para grileiros. Em apenas um dia, 02/02/2001, os corregedores identificaram a elaboração de dezoito dessas escrituras. 
Outro grande usurpador de terra pública no sul do Piauí e oeste da Bahia, segundo acusação da Promotoria Pública dos respectivos estados, é o empresário e colonizador rural baiano José Raul Alkimim Leão, proprietário da empresa Raul Leão - Agropecuária e Colonizadora (Agro-Pec), com sede em Brasília. Essa empresa organizou vários projetos de colonização nos cerrados nordestinos, principalmente para cooperativas do sul do Brasil. No Piauí, tal colonizador foi o responsável pela venda da gleba onde estão instaladas as famílias sulistas de Nova Santa Rosa, área pertencente a uma gleba de 68.900 hectares nos platôs dos municípios de Palmeira do Piauí, Bom Jesus e Uruçui. A área constitutiva do Projeto "Nova Mogiana", concebido e executado pela Agro-Pec, é mencionada nos documentos do Ministério Público Federal sob suspeita de ter sido adquirida pelo dito empresário através da ação de grilagem. Participam do Projeto "Nova Mogiana" vários empreendedores do agronegócio, como o ex-ministro da Agricultura do Governo Lula, Roberto Rodrigues; Grupo Kenyti Okano, grande produtor rural da região de Ituverava, São Paulo; Ivoncy Brochmann loschpe ${ }^{77}$, ex-presidente da Maxion, que fabrica tratores da marca Massey-Ferguson; dentre outros (Diário do Povo, 30/04/1999). A maneira pela qual José Raul Alkimim Leão se apropriou das terras do Projeto "Nova Mogiana” consta nos registros da Corregedoria Pública piauiense:

"No Cartório Único de Palmeira do Piauí, após as necessárias e percucientes investigações, além dos mesmos vícios encontrados em Bom Jesus e Cristino Castro, verificamos que por despacho prolatado pelo Juiz Plantonista, Osório Marques Bastos, no rosto de petição firmada por José Raul Alkimim Leão, e pelo seu advogado, Airton Teixeira Gomes, se a inafastável intervenção do

\footnotetext{
${ }^{77}$ A fazenda Vista Verde de produção de soja adquirida por esse empresário, foi objeto de fiscalização do Ministério do Trabalho, em 2005, onde os fiscais do trabalho encontraram trabalhadores em situação análoga à de escravidão, como aparece no depoimento de um dos trabalhadores contratados temporariamente para exercer atividades na fazenda, conforme consta no relatório:

“(...) Neste diapasão, relata o trabalhador Aluizio Pedro dos Santos (fl.30) '(...) que foi contratado dia 08/01/2005 pela empresa através do sr. Chico Novo para trabalhar na catação de tocos; que levanta(va) às 4 horas da manhã faz o almoço e vai para o campo; que, às vezes, caminha até 01 hora para chegar ao local de trabalho; que trabalha, mais ou menos, até o meio dia; que descansa e almoça em mais ou menos 01 hora; que, depois de comer, retorna novamente ao trabalho e vai até, mais ou menos, as $17 \mathrm{~h}$; que trabalha nesta jornada todos os dias, inclusive nos domingos e feriados; que não recebeu botas, nem luvas e nem chapéus; que trabalha de chinelo e com as mãos nuas; que os espinhos dos tocos de vez em quando furam suas mãos e seus pés". In: Relatório de Fiscalização (Fazenda Vista Verde Manoel Emidio - PI). Ministério do Trabalho e Emprego, novembro/2005.
} 
Ministério Público, portanto, em desacordo com a lei, 1.493,00,00 (hum mil e quatrocentos e noventa e três) hectares foram transformados em 68.900,00,00 (sessenta e oito mil e novecentos) hectares, indevidamente averbados na matrícula no. 1.748 daquela serventia. Após a indevida, ilegal e citada averbação, o senhor José Raul Alkimim Leão, adquirente do imóvel em alusão, através de sucessivas transações, o vendeu para terceiros, restando, apenas dos 68.900,00,00 (sessenta e oito mil e novecentos) hectares, uma área remanescente de aproximadamente 4.000,00,00 (quatro mil) hectares." (Correição extraordinária nos cartórios da comarca de Santa Filomena - PI Corregedoria Geral da Justiça do Estado do Piauí. Abril de 2001).

Prestigiado pelos grandes empresários rurais brasileiros, como ele próprio se promove numa reportagem paga no jornal piauiense "Diário do Povo", o colonizador José Raul Alkimim Leão atua no segmento do mercado imobiliário rural desde a década de 1980, inicialmente no oeste da Bahia, e, mais recentemente, no sul do Piauí. Diz ser proprietário de mais de 200 mil hectares de terra no Chapadão de Uruçuí, onde ocorrem instalações de fazendas destinadas à agricultura moderna. Para o Ministério Público, entretanto, as terras em poder de tal colonizador superam os 300.000 hectares, conforme menciona novamente o documento:

"Ressalte-se que José Raul Alkimim Leão, é o mesmo que se diz adquirente de uma área de 107.660,00,00 (cento e sete mil, seiscentos e sessenta) hectares de terras, em Avelino Lopes, e que, através de procedimentos ilegais e condenáveis, conseguiu a averbação de 68.900,00,00 (sessenta e oito mil e novecentos) hectares, em Palmeira do Piauí. Vê-se, pois, que se somando a área por ele adquirida e parte já ilegalmente averbada, perfaz um total de 312.560,00,00 (trezentos e doze mil e quinhentos e sessenta) hectares".

(Correição extraordinária nos cartórios da comarca de Santa Filomena - PI Corregedoria Geral da Justiça do Estado do Piauí. Abril de 2001).

As empresas do agronegócio, dentre elas as colonizadoras, são apontadas como os principais agentes promotores da rede de grilagem das terras no sul do Piauí, fenômeno que vem sendo alvo, atualmente, de investigação dos ministérios públicos estadual e federal, da Assembléia Legislativa do Piauí, da Polícia Federal, e, até mesmo, da Polícia Internacional (Interpol). A participação dessa última se deve à suspeita da existência de uma máfia estrangeira interessada em se apropriar de terras devolutas dos cerrados piauienses (Jornal Meio Norte, 19/06/2005). 
Após a efetivação de ampla apropriação irregular de terras devolutas que continua ainda em pleno vapor, surge nos últimos anos um intenso comércio imobiliário, principalmente envolvendo terras dos platôs planos cuja valorização econômica elevou os lucros dos especuladores. A apropriação privada das terras de uso comunitário não se restringe apenas a empresas do ramo imobiliário, como as colonizadoras (muitas delas remanescentes de empresas beneficiadas com recursos da SUDENE), mas se amplia para outros agentes econômicos: revendedoras de maquinários e equipamentos agrícolas, cooperativas, bancos, agricultores autônomos etc. O negócio com terra, circundando esses distintos ramos de atividades econômicas, denuncia que a terra transformada em mercadoria constitui um dos pilares do processo de acumulação capitalista, estruturadores da nova fase da modernização piauiense.

O acompanhamento do preço do hectare de terra nos últimos anos nos principais municípios de produção de grãos, como Uruçui e Bom Jesus, permite constatar uma grande valorização dessas áreas, principalmente as dos platôs, preferidas para servir de base à agricultura moderna. Atualmente, um hectare de terra bruta nos platôs é vendido pelo preço médio de trinta sacas de soja. Em meados dos anos noventa, entretanto, o hectare custava dez sacas de soja. No final dos anos oitenta, pagava-se por essa unidade de área uma saca de soja. Antes disso, porém, em meados dos anos oitenta, as terras planas dos platôs eram bem menos monetarizadas, costumava-se dizer, na região, que o hectare poderia ser adquirido pelo "preço de uma cerveja". Apesar de sua recente valorização, o preço da terra continua sendo o principal atrativo da população que se desloca para os cerrados piauienses.

As terras desses domínios, portanto, em que as comunidades locais usufruíam comunitariamente das riquezas naturais ali existentes, transformamse em posse de um seleto grupo de especuladores e produtores rurais, sem que ao menos se fosse pago por elas, pois sua apropriação ocorreu sob o desvio da lei. A apropriação privada dos platôs é a sentença final sobre o direito costumeiro praticado pela população local nessas áreas, restando-lhe agora reproduzir a vida lançando-se ao trabalho assalariado precarizado nas fazendas modernas, ou migrando para o urbano onde essa população se depara com novas formas de exclusão. 


\section{5 - A expansão do trabalho precarizado nas fazendas de soja dos cerrados piauienses}

Na reprodução do capital, na particularidade dos cerrados piauienses, as práticas de exploração do trabalho alheio não são distintas das ocorridas em outras áreas de expansão agrícola do Brasil. Cabe-nos perguntar: por que uma empresa como a transnacional Volkswagem que produz veículos automotores adotando as mais modernas tecnologias em suas fábricas na Alemanha ou em outros países nos mais diversos cantos do mundo, utilizou-se de mão-de-obra forçada em sua fazenda no sul do Pará no final da década de 1970? Procedimento que foi adotado também por tantas outras grandes empresas na sua lógica de imposição da acumulação capitalista. Não é difícil entender, entretanto, tal situação se considerarmos que é exatamente assim que se coloca o capital desde o início de sua formação, o que possibilitou a acumulação de riqueza não somente em poder desses grupos, mas dos países centrais, mantendo a expropriação e a exploração tanto de seus trabalhadores como do conjunto de países periféricos, como resgata Marx no célebre capítulo de O Capital, "A chamada acumulação primitiva” (Marx, 1968 [1890]). Nele o autor coloca em evidência o papel que os métodos coercitivos desempenharam, para que se tornasse possível o processo de acumulação, inclusive demandando das estruturas do aparelho estatal, como nos esclarece:

"Os diferentes meios propulsores da acumulação primitiva se repartem numa ordem mais ou menos cronológica por diferentes países, principalmente Espanha, Portugal, Holanda, França e Inglaterra. Na Inglaterra nos fins do século XVII, são coordenados através de vários sistemas: o colonial, o das dívidas púbricas, o moderno regime tributário e o protecionismo. Esses métodos se baseiam em parte na violência mais brutal, como é o caso do sistema colonial. Mas, todos eles utilizavam o poder do estado, a força concentrada e organizada da sociedade para ativar artificialmente o processo de transformação do modo feudal de produção no modo capitalista, abreviando assim as etapas de transição. A força é o parteiro de toda a sociedade velha que traz uma nova em suas entranhas. Ela mesma é uma potência econômica" (p.869).

Era necessário do mesmo modo criar as bases do trabalho assalariado mediante a expulsão dos camponeses de suas terras, para tanto o Estado é 
acionado dispondo dos seus aparatos de violência direta para tornar possível à liberação de mão-de-obra para a exploração do capital. Nesse sentido, Marx (1968[1890]:854), ao mencionar a formação de uma legislação contra os expropriados da Inglaterra e da França a partir do século $X V$, nos remete a reflexão do papel coercitivo do Estado como garantidor dos elementos que constituem a acumulação primitiva:

"Assim, a população rural, expropriada e expulsa de suas terras, compelida à vagabundagem, foi enquadrada na disciplina exigida pelo sistema de trabalho assalariado, por meio de um grotesco terrorismo legalizado em empregava o açoite, o ferro em brasa e a tortura".

Os métodos que se adotavam naquela sociedade do nascente sistema produtor de mercadorias manifestam também no início do século $\mathrm{XXI}$, ainda que modificados. Esse fator aponta que as bases com as quais se deu o processo de acumulação primitiva no período inicial da indústria moderna continuam, de certa maneira, presentes no atual período da sociedade sob a totalização da mercadoria. A diferença é que não ocorre mais o sistema de colonização como em outros tempos, dominado pelo mercantilismo ou por outras etapas da modernização. Entretanto, para a sua reprodução a "sociedade" continua adotando os mesmos recursos coercitivos de antes, mas com um caráter agora de homogeneização global. A violência continua sendo a referência para que aconteça a expropriação daqueles cujo trabalho proporcionará acumulação de riqueza ao capital. O Estado, nesse caso, é o que vai legitimar a ação do capital. Fica claro, portanto, entender porque a Volkswagem utiliza suas duas faces para se manter como uma grande empresa, gerando um contínuo movimento de não-simultaneidade capitalista.

Para Martins (1982: 16):

"[...] Em nosso país, nos dias de hoje, o capitalismo articula num só tempo, ainda que em espaços distintos, a expropriação e a exploração, processos que, a rigor, se deram separadamente na história clássica do capital. O mesmo grupo econômico nacional ou internacional, que utiliza técnicas sofisticadas e contratuais na exploração do trabalho do operário em São Paulo ou nas grandes capitais européias, utiliza a violência do jagunço, sobrepõe o poder privado ao poder público, para expropriar o posseiro na Amazônia e até mesmo emprega o trabalho escravo para abrir suas fazendas". 
Oliveira (2002: 74), ao analisar a modernização da agropecuária brasileira aponta nessa mesma direção, ou seja, no processo de expansão de relações capitalistas no campo, o capital estabelece uma lógica de imposição de valores que, a um só tempo, é contraditória e combinada. Como ressalta o referido autor:

"A análise da agricultura, especificamente a brasileira, neste final de século e milênio deve ser feita, portanto, no bojo da compreensão dos processos de desenvolvimento do modo capitalista de produção mundial. Esse procedimento passa necessariamente pelo entendimento de desenvolvimento como sendo contraditório e combinado, ou seja, ao mesmo tempo que segue reproduzindo relações especificamente capitalistas mais avançadas produz também, igual e contraditoriamente, relações não-capitalistas de produção e de trabalho, como as relações camponesas de produção, a peonagem etc.; todas necessárias à sua lógica de desenvolvimento."

No sul do Piauí, o capital se impõe confrontando essas velocidades distintas de reprodução. A sociedade mediada pelo mundo da monetarização, que acelera os processos de valorização do valor, depara-se com relações alicerçadas em outro momento da modernização, confirmando o descompasso dos tempos da reprodução. O que ocorre nas terras piauienses recentemente nada mais é do que a ampliação do descompasso. De um lado, a nova sociedade se organiza pelo uso de objetos tecnológicos modernos, como as máquinas de última geração, muitas delas guiadas por satélite para reduzir o "desperdício" dos grãos obtidos nos campos de produção de soja; Esses aparatos técnicos criam também as situações em que se observam pessoas em suas fazendas nos gerais em freqüente conexão com o mercado global acompanhando os preços de seus produtos praticados nas grandes bolsas de mercadorias mundiais. Esse novo Piauí globalizado que se forja no discurso dos órgãos estatais ou na grande mídia não eliminou, contudo, a exploração aviltante dos trabalhadores, principalmente da população camponesa, carente de acesso às redes de informação ou de proteção restritas a um seleto grupo de indivíduos da sociedade contemporânea.

As condições de extrema precariedade de trabalho nos cerrados piauienses são denunciadas por sindicatos de trabalhadores e constatadas em investigações promovidas pelo Ministério do Trabalho e do Emprego naquela área. Os relatórios de fiscalização emitidos por esse órgão nos últimos anos, a 
respeito da contratação do trabalho nas fazendas produtoras de grãos do sul do Piauí, denunciam inúmeras irregularidades cometidas pelos representantes do agronegócio. Os procedimentos ilegais de exploração do trabalho alheio em nada diferem de outros momentos da modernização capitalista.

São incontáveis as ocorrências constatando situações humilhantes vividas pelos trabalhadores braçais nas fazendas de soja mantidas por empresas e/ou produtores individuais. Somente nos últimos cinco anos, momento em que as lavouras modernas cresceram substancialmente em área e produção nos cerrados piauienses, o Ministério do Trabalho e do Emprego encontrou grandes levas de camponeses em condições de trabalho degradantes nas fazendas de produção de soja. Constou-se que a manutenção dessas práticas de trabalho precarizadas ocorria com mais intensidade nos campos agrícolas pertencentes a grandes grupos econômicos instalados no sul do Piauí, demonstrando que a ampliação da riqueza por parte desses grupos se faz sustentada na exploração extrema de trabalhadores, principalmente da população camponesa menos capaz de se desvencilhar das armadilhas impostas pelos processos de modernização contemporânea.

As novas relações de trabalho difundidas pela agricultura moderna nos cerrados piauienses são representativas do quão coercitivos são os meios adotados para promover o sistema produtor de mercadorias. No contexto de ampliação da modernização em que se insere o sul do Piauí recentemente, a população camponesa não é apenas expropriada de seus meios de produção, necessitando monetarizar sua força de trabalho, senão que se submete a um regime de trabalho de extrema exploração, comparável aos de períodos mais sombrios da acumulação primitiva ocorridos nas mais diversas partes do planeta.

Os postos de trabalho gerados pela ampliação da produção agrícola moderna piauiense resumem-se a algumas poucas atividades cuja máquina não pode realizar, freqüentemente tarefas extenuantes executadas sob a vigilância disciplinada de emissários administradores dos interesses das empresas do agronegócio. As ocupações para as quais são contratados trabalhadores piauienses (denominados de catadores) consistem basicamente 
em tarefas de recolher os resíduos de vegetação encontrados no solo, uma árdua empreitada que, às vezes, ocupa mais de dez horas diárias em condições ordinárias de trabalho. Além disso, a execução de tais atividades ocorre em locais distantes das moradias dos trabalhadores (homens, mulheres e crianças), exigindo permanência deles nas fazendas de produção de soja durante dias em frágeis alojamentos; comumente, são barracos de lona plástica preta ou de palhas sem qualquer proteção nas laterais correndo riscos de serem atacados por animais, sofrendo os efeitos do calor e dos ventos intensos muito freqüentes na estiagem, período em que ocorre o preparo das fazendas para o plantio agrícola. Faltam-Ihes, também, acomodações para dormir, para preparar os alimentos e para satisfazer às necessidades fisiológicas. Não são disponibilizados aos trabalhadores equipamentos de proteção individual, a não ser que eles próprios comprem da empresa contratadora ou do agenciador por um preço por vezes muito superior ao que poderia ser adquirido no mercado.

Essas formas de exploração extrema de trabalhadores piauienses recém-ingressados no assalariamento foram registradas em diversos relatórios de fiscalização do Ministério do Trabalho. Nesses documentos são retratadas condições indecorosas, às quais se submetem famílias inteiras de camponeses expropriados, comprovando tratar-se de uma prática notória das empresas agrícolas modernas instaladas recentemente nos cerrados piauienses. Dentre os inúmeros casos de empresas do agronegócio que adotam métodos coercitivos contra trabalhadores encontra-se o da denominada "Fazenda Cosmos", pertencente ao empresário Eduardo Dall Magro, detentor de uma extensão de 37 mil hectares de terra no município de Ribeiro Gonçalves. As diligências fiscalizatórias assinalaram, em 2004, a presença, nas dependências de tal fazenda, de trabalhadores em indignas condições de sobrevivência, conforme nos indicam alguns trechos do referido documento:

"Não obstante o trabalho escabroso desempenhado pelos trabalhadores sob um sol inclemente o dia inteiro, foi constatado que a empresa não havia tomado qualquer providência visando ao menos amenizar o sofrimento destas pessoas ocasionado pela situação de trabalho aviltante a que eram submetidas. Ao contrário, as verificações físicas e os depoimentos colhidos na 
ação fiscal demonstraram que, além de não Ihes fornecer nenhum tipo de equipamento de proteção individual, ainda submetia a uma jornada de em média 10 horas diárias, inclusive aos sábados, domingos e feriados. (...) Dramático também foi o caso do trabalhador Luciano Cesário Lopes, que, mesmo sem comer há dois dias, devido a uma inflamação provocada por um dente, e sem assistência alguma, ainda teve que caminhar mais de $60 \mathrm{Km}$ de volta para casa. (...) Durante a ação fiscal foi constatado que os empregados também não tinham qualquer conforto na ocasião das refeições, que eram realizadas nos próprios barracos, sem as condições mínimas de higiene e sem a existência de sequer uma mesa ou de cadeiras. Entre os empregados, e submetidos ao mesmo tratamento desumano, constatamos a presença de dois menores, de dezesseis anos e menor de quinze anos de idade. (...) Com efeito, a empresa, através do sr. Luizão, fornecia aos empregados, além de gêneros de primeira necessidade, botas, que deveriam ser fornecidas gratuitamente, $e$ drogas nocivas, como fumo e cachaça, todos a preços superiores aos praticados nas cidades mais próximas".

(Relatório de Fiscalização (Fazenda Cosmos - Ribeiro Gonçalves-PI) - Ministério do Trabalho e Emprego/Delegacia Regional do Trabalho-PI, julho de 2004).

Em um outro relatório de fiscalização do Ministério do Trabalho e do Emprego, do ano de 2003, a Reflorestadora Serra Branca Ltda, instalada no município de Uruçuí, mas com sede em Londrina/PR, aparecia como uma das empresas que também adotava procedimentos ilícitos nas relações de trabalho mantidas com empregados da fazenda. Constam no documento doze autuações de infração contra essa empresa por não cumprimento das leis trabalhistas. Dentre outros, destacam-se o fato de que os seus empregados não obtinham registro em carteira e para contratá-los a empresa utilizava os serviços do agenciador (o "gato"). Sendo que cabia a esse último agente econômico desempenhar a função de "arregimentar, contratar, além de acompanhar o desempenho dos empregados no campo, proceder às medições das áreas desmatadas para apuração da produção, e, principalmente, realizar pagamento do salário" ${ }^{78} \mathrm{Da}$ quantia de 15,00 reais que a empresa desembolsava pela limpeza de um hectare de mata derrubada, apenas 10,00 reais era repassado aos trabalhadores contratados, os 5,00 reais restantes permaneciam com o agenciador pelos serviços prestados de arregimentar trabalhadores e mantê-los sob seu controle. Além disso, esse agente cumpria também a tarefa de descontar do pagamento dos

\footnotetext{
${ }^{78}$ In: Relatório de Fiscalização (empresas dos cerrados piauienses - Uruçui, Ribeiro Gonçalves e Baixa Grande do Ribeiro). Serviço Público Federal/Ministério do Trabalho e do Emprego, junho/2003.
} 
trabalhadores "equipamentos de proteção (botas) e outros objetos essenciais ao desempenho da atividade" e ainda as despesas decorrentes das mercadorias (com preços superfaturados) adquiridas no comércio mantido pelo próprio agenciador.

Essas denúncias que se repetem em grande número pelos cerrados piauienses não diferem muito dos registros de outros contextos históricos que serviram de base para a formação do moderno sistema produtor de mercadoria, como 0 dos trabalhadores ingleses proletarizados pela a Revolução Industrial (Engels, 1986 [1845]). A aceleração dos processos de modernização capitalista que se evidenciava na Europa industrial representou para tais trabalhadores a sua inserção nas mais severas condições de miséria nas emergentes cidades, mas também no campo, devido à destituição de seus antigos meios de produção e de sua inserção na lógica de produção capitalista através do assalariamento (Marx, 1968 [1890]).

A tentativa de homogeneização dos processos de reprodução do capital gera, portanto, a perversidade indiscriminada em todos os momentos da construção história do sistema, deixando rastros de destruição e degradação nas condições de vida dos trabalhadores. Os processos de modernização contemporânea dos cerrados piauienses denunciam a manutenção dessa lógica, confirmando que o capital ao empreender a unificação global do sistema produtor de mercadorias adota em suas práticas o uso da violência. Novamente os registros encontrados nos referidos relatórios de fiscalização das fazendas agrícolas modernas deixam claro a que condições são submetidas as populações encarregadas da produção das mercadorias:

"Os trabalhadores da fazenda foram encontrados alojados em barracos precários cobertos de lona plástica preta, piso de chão bruto, sem proteções laterais e, ainda, sem qualquer tipo de instalação sanitária destinada ao aseio corporal e à realização das necessidades fisiológicas. [...] Alguns empregados dormiam em uma casa abandonada que não possuía sequer cobertura". (Relatório de Fiscalização (empresas dos Cerrados Piauienses - Uruçuí, Ribeiro Gonçalves e Baixa Grande do Ribeiro) - Ministério do Trabalho e Emprego/Delegacia Regional do Trabalho-PI, junho de 2003).

Os casos de abusos contra os trabalhadores promovidos pelos representantes do agronegócio envolvem também grandes grupos econômicos do centro-sul do País. O grupo Comil é um deles. Essa grande empresa 
brasileira, com matriz instalada em Erechim (RS) e filial no México, que atua na produção de carrocerias de ônibus e no setor de construção de silos e secadores de grãos, investe seu capital igualmente em fazendas de soja nos cerrados piauienses. Na "Fazenda Comil", no município de Uruçuí, foram encontradas situações de exploração do trabalho análogas às de outras empresas denunciadas acima. Além das condições precarizadas dos alojamentos aos quais os trabalhadores temporários faziam uso durante sua permanência na fazenda, a empresa servia-lhes água para consumo em tambores de produtos químicos, ocasionando a esses trabalhadores danos à sua saúde. Constam ainda outras formas de violência praticadas pelo grupo econômico, tais como coação física contra os trabalhadores contratados, conforme expressam as informações constantes no relatório de fiscalização:

"Em virtude dos trabalhadores terem sido encontrados em situação de trabalho degradante, agravada pelo fato de desempenharem suas atividades em uma região localizada a mais de $100 \mathrm{~km}$ de Uruçuí, de difícil acesso e sem transporte regular, foram tomadas pelos signatários as seguintes providências: os trabalhadores foram retirados do local e transportados até Uruçuí. [...] As CTPS dos empregados não foram assinadas pela empresa durante estes procedimentos em virtude dos seguintes fatos: a maioria dos trabalhadores não possuía CTPS e eram originários de outros municípios distantes como: Canto do Buriti, Colônia do Gurguéia e Guaribas; a empresa ainda não possuía CNPJ e nem CEI e, principalmente, devido ao caráter imediato das providências exigidas. Além disto, os empregados estavam apreensivos e temerosos, uma vez que existiam várias denúncias de trabalhadores feitas ao Sindicato, não reduzidas a termo, de que o encarregado da empresa, Sr. Antônio Valmir Rosa Machado, é uma pessoa violenta, que anda armado, e que, inclusive, já teria expulsado 'à bala' vários trabalhadores que prestaram serviços à Fazenda Comil"

(Relatório de Fiscalização (empresas dos Cerrados Piauienses - Uruçuí, Ribeiro Gonçalves e Baixa Grande do Ribeiro) - Ministério do Trabalho e do Emprego/Delegacia Regional do Trabalho-PI, junho de 2003).

Como se vê, o capital vai às últimas conseqüências para retirar do suor do trabalhador a mais-valia necessária à ampliação do valor, mesmo que para isso tenha que dispor de métodos explícitos de violência. Tal tarefa é facilitada pela conivência e/ou legitimação do Estado, mas, também e principalmente pela grande disponibilidade de pessoas sem nenhum trabalho e que buscam qualquer tipo de ocupação por mais precarizada que ela possa ser. Essa força de trabalho excedente, todavia, representa uma reserva importante para a 
valorização do capital. Ela foi, portanto, mobilizada para assegurar ao capital os meios de sua reprodução. Assim, como enfatiza Gaudemar (1977: 56), “(..) os homens estão disponíveis, o seu trabalho compra-se e vende-se facilmente num mercado alimentado permanentemente pelos desempregados e rurais desenraizados". Os trabalhadores camponeses dos cerrados piauienses que se submetem ao assalariamento de extrema precariedade transformam-se, dessa maneira, em desenraizados nas fazendas de produção agrícola modernas.

A necessidade de se manterem (sobretudo agora, após a redução de seus espaços de sobrevivência, como é o caso dos gerais) leva esses trabalhadores a se lançarem nessas redes de exploração do trabalho. Para tornar tal tarefa mais facilitada as empresas requisitam aos agenciadores de trabalho no seio da própria comunidade, buscam com isso proteger ao máximo seus nomes em situações de ilegalidades trabalhistas. Esses agentes que agem a mando do capital são importantes na engrenagem de funcionamento do agronegócio, pois acobertam aqueles que verdadeiramente se beneficiam dessas práticas. Tal estratégia das empresas agropecuárias foi constada em mais um dos relatórios de fiscalização do Ministério do Trabalho e do Emprego em 2005, no município de Manoel Emidio - PI. Tratava-se, desta vez, da fazenda Vista Verde, de propriedade do empresário Ivoncy Brochmann loschpe. Segue abaixo um pequeno trecho do relatório no qual desvenda um dos papéis a que se subordina o agenciador de trabalho:

"Pelo que apuramos, o 'gato', como empregado da empresa, era um mero preposto que recebia incumbência de recrutar e contratar trabalhadores em nome dela, única beneficiária desta exploração, e quem na verdade remunerava os empregados".

(Relatório de Fiscalização (Fazenda Vista Verde - Manoel Emidio - PI) - Ministério do Trabalho e Emprego/Delegacia Regional do Trabalho-PI, novembro de 2005).

As empresas praticamente não despendem seus recursos com o agenciador, pois os rendimentos deste indivíduo são obtidos do que ele retira de seus contratados. Ao arregimentá-los, o "gato" estabelece acordos de receber, pela tarefa da intermediação, parte do salário que deveria ser pago ao trabalhador. Em um dos povoados visitados no município de Currais, depareime com uma situação que retratava bem 0 funcionamento desse 
universo de relações de trabalho envolvendo a empresa agropecuária, o agenciador e os trabalhadores contratados para prestar serviços temporários numa futura fazenda de soja. No diálogo com uma senhora proprietária de uma pequena mercearia daquela localidade ela me relatava que seu esposo encontrava-se ausente naquele momento, pois foi incumbido, por um novo proprietário de terras nos cerrados piauienses, de recrutar trabalhadores entre seus pares para a limpeza da área, restos de vegetação deixados pelas máquinas desflorestadoras. O pagamento ao agenciador era proporcional à quantidade de trabalhadores recrutados e o que esses aceitariam receber para a execução do serviço; quanto menor o preço pago aos trabalhadores, maiores os lucros do agenciador, que obtinha vantagens nessa relação pelo fato de possuir uma mercearia onde os contratados poderiam comprar produtos para suas necessidades. A função do agenciador, entretanto, relatava sua esposa, também era a de controlar qualquer tipo de manifestação de desagravo por parte do trabalhador contratado, durante o período em que ele permanecesse executando serviços na área que se destinaria à produção de soja.

Muitas das empresas preferem contratar os mediadores de trabalho da própria comunidade, pelo fato das relações familiares e afetivas (ou mesmo morais) se submeterem cada vez mais às questões econômicas. Por participarem de um mesmo universo de valores, os novos agentes econômicos dos cerrados piauienses se beneficiam do pacto que se cria entre o grupo contratado. Surgem daí as condições ideais para a exploração desmedida da força de trabalho local resultantes da presença de empresários ávidos por maximizar seus lucros de maneira imediata e da situação de carência econômica extrema de famílias camponesas. O cenário de reprodução do capital se completa nessa área pela deficiência do aparelhamento estatal que pudesse coibir de maneira mais eficaz as ações dos grupos econômicos que se favorecem de práticas ilícitas de exploração do trabalho.

Esse processo de modernização contemporânea dos cerrados piauienses produziu uma situação nova no estado: antes o Piauí figurava como uma das principais áreas do Brasil de "exportação" de trabalhadores para serem utilizados em trabalhos forçados em outras regiões do país; 
atualmente, entretanto, além de continuar "exportando", passa também a absorver trabalhadores nessas condições. As áreas piauienses apontadas como as principais de disseminação dessas formas de precarização do trabalho correspondem às de cerrados, principalmente àquelas onde instalaram as empresas agropecuárias modernizadas.

As estratégias de arregimentação de trabalhadores nos cerrados piauienses mantêm muitas semelhanças com àquelas dos capitalistas ingleses do século XIX, os quais contratavam trabalhadores, principalmente mulheres e crianças, para as tarefas na lavoura em condados da Inglaterra oriental, relação de trabalho conhecida como "sistema de bandos", relatado por Marx (1968: 807[1890]). Embora nesse caso o sistema de bandos tenha menor participação de homens adultos, contrariamente ao que ocorre no sul do Piauí - mas há também, nesse último, participação marcante de mulheres e crianças -, serve para identificarmos certas semelhanças nos métodos adotados pelo capital para a formação das bases de sua acumulação em períodos históricos e em espaços diversos, como fica explícito no trecho que segue:

"A terra exige muito trabalho leve como o de arrancar as ervas ruins, sachar, adubar, limpar o terreno de pedras etc. Essas tarefas são realizadas pelos grupos ou bandos organizados, sediados nas aldeias abertas. O grupo é constituído de 10 a 40 ou 50 pessoas, mulheres jovens de ambos os sexos entre 13 e 18 anos, embora os rapazes de 13 anos sejam em regra excluídos, e finalmente crianças de ambos os sexos entre 6 e 13 anos. À frente deles está o chefe do bando, um trabalhador agrícola comum, geralmente velhaco, debochado, boêmio, bêbedo, mas com certo espírito de iniciativa e 'savoir faire'. Ele recruta o bando que trabalha sob suas ordens e não sob as do arrendatário. Ajusta com este por empreitada, e seu ganho, que em média não ultrapassa de muito o de um trabalhador agrícola comum, depende da habilidade de fazer seu bando realizar a tarefa contratada no menor tempo possível. (...)"

As relações de trabalho na Inglaterra no século XIX expostas acima ou as ocorridas nos cerrados piauienses atualmente, no início do século XXI, deixam claro que o capital age adotando métodos similares em qualquer tempo histórico e espaço geográfico. Tornam-se nulos, portanto, os discursos do status quo de que vivemos numa sociedade na qual, pretensamente, todos possuem uma suposta liberdade de oferecer sua mercadoria, força de trabalho, 
a quem quer que seja, num movimento de livre concorrência. A realidade, no entanto, é outra; estão escondidas aí as leis de reprodução do capital, sinalizadas pela adoção de um amplo aparato de violência explicita e implícita, mantida por meios particulares e/ou delegando essa função ao Estado.

As transformações em curso nos cerrados piauienses apontam, nesse sentido, um processo de reorganização das bases de ampliação do capital naquela região. As atividades sustentadas na agricultura camponesa e na pecuária extensiva - até recentemente as principais responsáveis pela economia do sul do Piauí - são substituídas rapidamente por novas estruturas de produção, sob a liderança da agricultura capitalista. Os campos agrícolas detentores de técnicas sofisticadas de produção e as novas formas de consumo surgidas nas cidades sul piauienses, como veremos no próximo capítulo, são indicativos de uma modernidade em curso pautada na nãosimultaneidade.

A idéia de que agronegócio transformou-se, conforme o discurso dominante, na salvação dos cerrados piauienses que, segundo alega, sempre foi carente de modernidade se desfaz diante da expressão de aprofundamento de processos não-homogêneos gerando novas modalidades de crises para aquela área. Esses reflexos da modernização contemporânea se aplicam porque as empresas que contratam profissionais com especializações seguindo os preceitos da chamada empresa moderna são as mesmas que utilizam famílias camponesas (inclusive crianças) para serviços pouco dignificados, concedendo-lhes remuneração irrisória e sem as garantias trabalhistas legais. Elas comercializam suas mercadorias agrícolas adotando os preços do mercado internacional, pois estão sintonizadas em tempo real com o comércio das principais bolsas de valores do mundo; mas, ao mesmo tempo, apropriam-se, ilegalmente, dos espaços de vida da população local, destruindo os recursos naturais importantes para aquele contexto social. Essa população expropriada, por conseguinte, transforma-se na massa de trabalhadores desenraizados e sem trabalho que busca também a sobrevivência no urbano, que, aliás, não os pode incluir, visto que se converte do mesmo modo em um espaço de manifestação da crise. 


\section{5 - AS TRANSFORMAÇÕES NO URBANO DOS CERRADOS PIAUIENSES}

A expansão da fronteira agrícola para os cerrados brasileiros, sobretudo nas últimas décadas, caracterizou-se por um novo ordenamento territorial tanto do espaço agrícola quanto do urbano. No espaço de produção agrícola destaca-se o papel das novas técnicas incorporadas a esse setor, que possibilitaram não somente um aumento substancial no volume de produção agropecuária do país, mas foram responsáveis também pela inserção de novas áreas para a agricultura capitalista, como as dos cerrados. Esse bioma, no qual até a década de 1960 predominava uma ocupação camponesa e de pecuária extensiva, ganha agora centralidade no contexto de produção agrícola moderna.

O urbano dessas áreas, da mesma maneira, segue uma trajetória de mudanças importantes. Se antes apresentava uma área tênue, recentemente as cidades do agronegócio adquirem crescimentos expressivos. Cita-se aqui, dentre outras, as do norte de Mato Grosso (Aripuanã, Colider, Sorriso, Sinop, Juina, Alta Floresta etc.); oeste da Bahia (São Desidério, Barreiras e Luis Eduardo Magalhães); sul do Maranhão (Balsas) e sul do Piauí (Uruçuí e Bom Jesus). Na fronteira agrícola, a nova urbanização se submete aos anseios das atividades agrícolas e a eles se subordina, isto é, organiza sua vida econômica e social ao ritmo e às necessidades da produção da agricultura moderna.

Como vimos no capítulo 3 , as cidades da fronteira agrícola se especializam em serviços para atender às atividades produtivas do campo: lojas de maquinários, de sementes e de defensivos; escritórios de prestação de serviços agropecuários etc. Nesses lugares observa-se também um intenso fluxo de caminhões nos postos de combustíveis e os últimos modelos de camionetas, estas representando os símbolos de status dos novos ricos do campo. É uma constante, ainda, o acontecimento das feiras do agronegócio, cujo volume de dinheiro movimentado supera a arrecadação anual de muitos dos municípios brasileiros. A paisagem no entorno dessas cidades, do mesmo modo, denuncia a interferência da agricultura na dinâmica urbana local, através dos grandes silos, dos armazéns e das instalações das plantas de fábricas das processadoras de soja. Enfim, visitar uma cidade da fronteira agrícola é 
acompanhar as profundas transformações em curso do Brasil agrário contemporâneo.

\section{1 - O antigo urbano dos cerrados piauienses e suas novas dinâmicas}

Embora mais recente do que em outras áreas brasileiras de inserção da agricultura moderna, a urbanização dos cerrados piauienses se destaca nos últimos dez anos, motivada pela instalação de famílias sulistas e de empresas do agronegócio, além dos camponeses expropriados, antigos habitantes do entorno rural. Esse movimento é mais intenso naqueles municípios com grande presença de terras de platôs. As cidades dos cerrados que antes se moviam predominantemente pela lógica do tempo camponês, quase imóvel no que se refere a alterações em sua paisagem, adquirem agora novas formas e novas funcionalidades. O tempo do capital se impõe pela presença das empresas e dos produtores agrícolas modernizados, os quais imprimem maior velocidade nas mudanças espaciais, seja adensando o urbano com novos objetos fixos gerando, por conseguinte, maior fluidez de pessoas e de mercadorias (Santos, 1996), seja alargando o tamanho do urbano com a presença de novos moradores.

Há vários municípios do sul do Piauí (Corrente, Gilbués, Santa Filomena, Ribeiro Gonçalves, Baixa Grande do Ribeiro etc.) com um novo dinamismo urbano provocado pela chegada de grupos que trabalham com a agricultura moderna, mas Uruçuí e Bom Jesus apresentam mais nitidamente as mudanças em curso. Estes dois municípios tornaram-se os maiores produtores de grãos do estado, condição alcançada nos últimos anos por conta da expansão das lavouras de soja. Ambos receberam recentemente um volume considerável, para os padrões locais, de migrantes e de empresas. A presença desses grupos trouxe mudanças importantes tanto na dinamização da área urbana quanto na incorporação de novos costumes antes estranhos aos piauienses dos cerrados, como freqüentar churrascarias, pizzarias e padarias (fotos 20 e 21). 


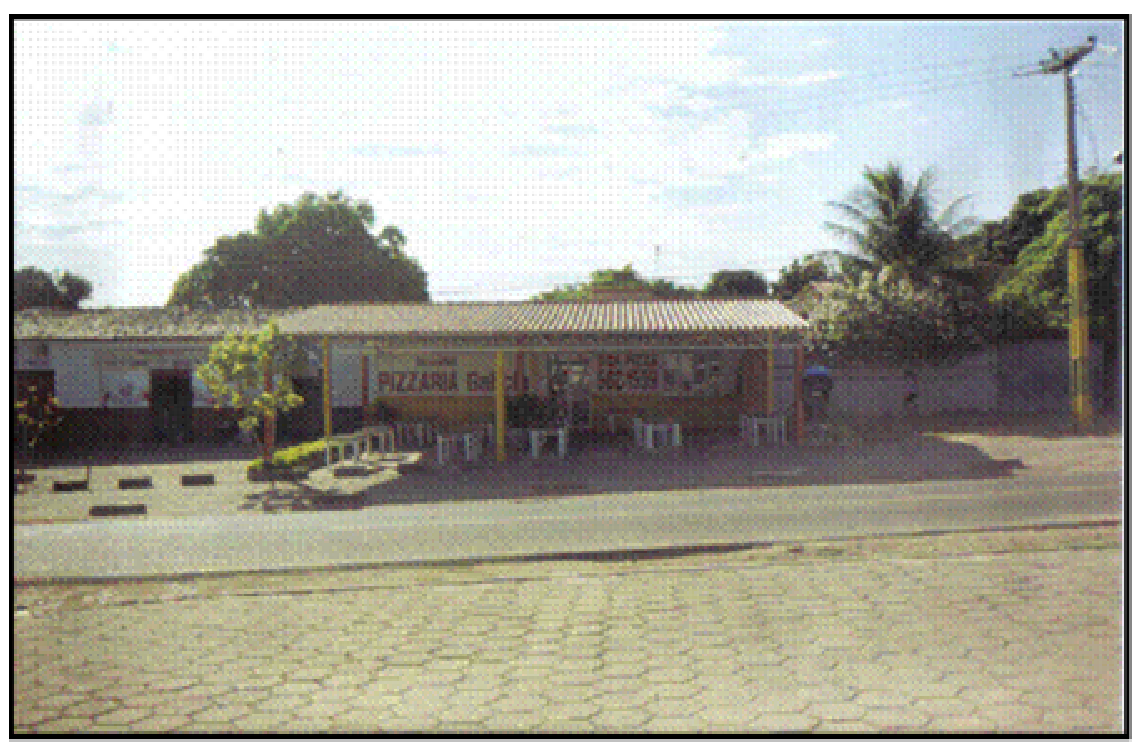

Foto 20 - Pizzaria no municipio de Bom Jesus, Foto do autor. setembro de 2003.

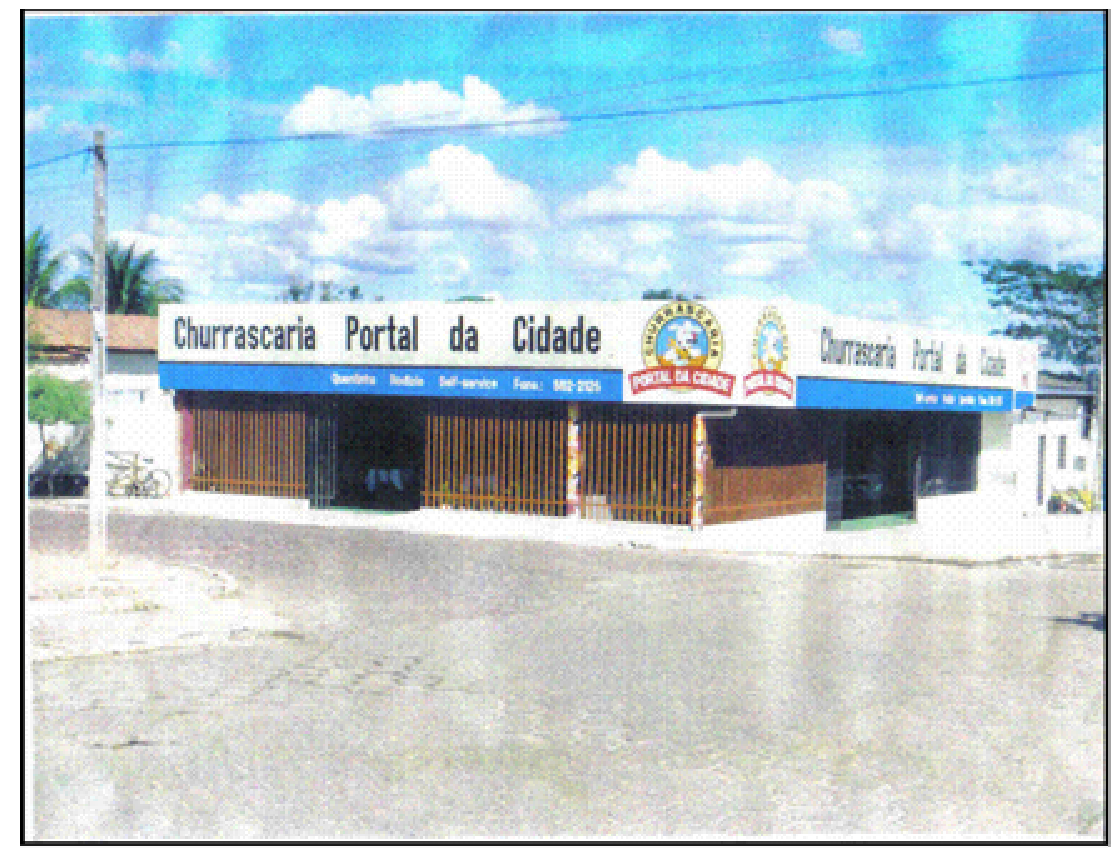

Foto 21 - Novos serviços instalados nas cidades dos cerrados piauienses, atê recentemente estranhos à população local - Bom Jesus. Foto do autor, setembro de 2003. 
Nota-se que, em um curto intervalo de tempo, a paisagem dessas cidades adquire novas formas e funções. Nela, não se refletem mais apenas os traços da cultura piauiense, mas são cada vez mais nítidos novos elementos na sua constituição, anunciando as transformações em curso. Além das empresas que se instalam interessadas em atender às novas demandas, sobretudo no comércio e nos serviços voltados para o consumo produtivo, surgem também outros estilos de vida trazidos pelos novos habitantes, ajudando a compor novas manifestações sociais e formas de organização da paisagem. Nesse contexto, destacam-se: a introdução dos cultos da igreja luterana antes estranhos aos moradores dessa sub-região dos cerrados nordestinos; bailes gaúchos; erva mate nas prateleiras dos supermercados para o preparo do chimarrão, ou outros produtos destinados aos novos moradores; bairros predominantemente de população sulista; características distintas na organização das residências que, além de uma arquitetura diferenciada, mantêm outra relação com o espaço da rua. Freqüentemente, as casas dos sulistas são muradas, dificultando a interação de seus moradores com a rua, o oposto do que ocorre tradicionalmente com as antigas residências dos piauienses, construídas fazendo fronteira quase que diretamente com a rua, separadas apenas por uma calçada. Nas primeiras, o quintal é instalado na parte da frente, nas segundas, no fundo. Até mesmo as cores das casas, segundo nos alertava um fotógrafo de Bom Jesus, foram alteradas com a chegada dos sulistas: "Estes preferem tonalidades mais diversificadas".

Esses fatores indicam o aparecimento de um outro sentido nas características de ocupação do urbano-sul piauiense. As mudanças produzidas, entretanto, são mais incisivas nas manifestações econômicas, sobretudo nas que se referem a novas formas de consumo. As cidades (especialmente as anunciadas acima) transformam-se, em pouco tempo, de portadoras de atividades econômicas de fraca expressão (sustentadas, predominantemente, na agricultura de subsistência e na pecuária extensiva) em fornecedoras de bens e serviços dotados de grande aporte técnico.

Esse movimento de modernização agrícola dos cerrados permitiu, como as estatísticas indicam, a expansão do comércio e dos serviços naquelas cidades que mais receberam fluxo de capital decorrente das atividades agrícolas. Esse fator de alguma forma atinge positivamente a população local, 
principalmente pela ampliação de serviços antes escassos nesses lugares, como os de saúde e de educação, mas também porque possibilitou a alguns habitantes locais terem acesso a novas ocupações, mesmo ocorrendo às vezes em condições de precarização absoluta e por tempo limitado. As profissões mais requisitadas são aquelas com maiores especializações, tais como: tratoristas, técnicos agrícolas, agrônomos, mecânicos, etc, ocupadas principalmente por pessoas de outros estados. Mas há também inserção da população local em algumas das novas profissões, como as de mecânico, borracheiros ou mesmo técnicos agrícolas.

Tanto em Uruçuí quanto em Bom Jesus é visível a ampliação da rede hoteleira, de supermercados, de lojas de maquinários e de material de construção. Estas últimas obtiveram crescimento expressivo em ambas as cidades, indicando que a expansão desse setor ocorre por conta da construção de novas moradias para os que chegam, além dos galpões, armazéns e estabelecimentos de outros segmentos econômicos ${ }^{79}$. No que diz respeito à rede hoteleira é significativa a sua ampliação nessas cidades; além disso, houve uma substancial mudança nas características dos hotéis, tanto nos seus aspectos físicos quanto no seu atendimento. As estruturas que antes eram simples, oferecendo serviços deficientes, contrastam com as atuais, cujas instalações são mais modernas e confortáveis, visando atender aos novos consumidores. Os preços também foram inflacionados muito próximo aos cobrados pelas grandes redes hoteleiras dos principais centros urbanos do país.

Os postos de combustíveis, da mesma maneira, expandem-se nessa área e recebem um grande volume de caminhões. Em Uruçuí, por conta da instalação da Bunge Alimentos, há uma grande circulação desses veículos de carga atravessando as ruas estreitas do centro urbano da cidade. Costuma-se, em épocas de maior movimento produzido pelo abastecimento dos silos da empresa, circular pela cidade diariamente cerca de 500 caminhões com grande

\footnotetext{
${ }^{79}$ De 2000 a março de 2004 foram abertas 457 novas empresas em Uruçuí, a maioria delas estabelecimentos comerciais. In: Folha de S.Paulo (Caderno Dinheiro), 14 de março de 2004. No caso de Bom Jesus, Araújo (2006) identificou nos cadastros do Departamento Tributário do município, entre os anos de 1997 e 2005, um acréscimo de 331 novos estabelecimentos comerciais e de serviços no município.
} 
impacto no calçamento das ruas, nas estruturas das casas, além da poluição sonora.

Tal movimento da modernização contemporânea trouxe consigo, entretanto, outros impactos importantes a essas cidades. Dentre eles a grande valorização no preço da terra urbana, semelhante ao que ocorre com a terra dos platôs destinada à agricultura. O fenômeno da especulação imobiliária do solo urbano e rural tornou-se uma das principais expressões do comércio de terras nos cerrados piauienses. De meados da década de 1990 em diante, a grande procura por terrenos em alguns desses núcleos urbanos produziu uma rápida expansão do preço da terra, digna de comparação com a que ocorreu na formação das metrópoles brasileiras no seu período de maior expansão. Em Uruçuí ou em Bom Jesus, um terreno, que no ano 2000 podia ser adquirido por 5.000 reais, em 2006 não sai por menos de 50.000 reais, podendo alguns chegar a 250.000 ou até 300.000 reais, dependendo da sua localização no perímetro urbano ${ }^{80}$. Os detentores desse comércio imobiliário são alguns dos antigos moradores locais que visualizaram a acumulação de seu capital nesse negócio, mas também sulistas que tiveram experiências nesse ramo em outras regiões de fronteiras agrícolas.

Essa exponencial valorização dos imóveis ocorre porque os novos agentes econômicos se dispõem a pagar os preços estipulados, na medida em que os migrantes sulistas demonstram posse de maior poder aquisitivo, fato que estimula o especulador imobiliário a definir suas políticas de preços. É possível, nesse sentido, classificar boa parte da população que desembarca no sul do Piauí dentro dos estratos sociais mais elevados. Seus recursos permitem manter um bom padrão de vida nessas cidades; circulam, em grande número, com carros modernos; as casas onde moram são amplas e muitas delas com piscinas; os filhos estudam, em sua grande maioria, nas poucas escolas particulares existentes.

Os processos de aceleração da modernização em curso produzem no urbano dos cerrados piauienses, sobretudo naqueles que mais recebem migrantes sulistas, novos sentidos também na composição do poder político

${ }^{80}$ No município de Uruçuí entre os anos de 2002 a 2003, período de construção das instalações da Bunge, os preços dos aluguéis dos imóveis em poucos meses ampliaram-se em mais de dez vezes aos cobrados anteriormente. 
local. Os grupos locais não comandam mais sozinhos as instâncias públicas de alguns municípios dos cerrados, dividem-nas agora com os novos habitantes, os quais passam a compartilhar das esferas de decisões. As alianças entre os dois grupos se ampliam para outras frentes políticas, como as articulações para formar um movimento visando à criação do estado do Gurguéia. Embora seja um desejo antigo dos que sempre conservaram o poder político local, ele se amplia com a presença dos representantes do agronegócio que despertam interesses pela existência de um estado independente no sul do Piauí, para atender mais prontamente às suas reivindicações. Tal movimento pelo desmembramento do território, que adquire uma nova configuração pela ação da agricultura capitalista moderna, não se limita aos cerrados piauienses, mas acontece nas outras áreas de expansão da fronteira agrícola brasileira, indicando um fenômeno que ganha expressividade e do qual passam a fazer parte os novos agentes do agronegócio. Além da criação do estado do Gurguéia (em que já existe a relação dos municípios piauienses que comporão o novo estado, bem como, sua futura capital: Alvorada do Gurguéia), ocorrem movimentos a favor da formação dos estados do Rio São Francisco (no oeste da Bahia, com capital em Barreiras, mas já surgem reivindicações para que se estabeleça em Luis Eduardo Magalhães); Maranhão do Sul (sul do Maranhão, com capital em Imperatriz) e Araguaia (norte do Mato Grosso, com capital em Sinop) (Nonato, 2005).

Vê-se, assim, que a instalação dos agentes econômicos do agronegócio na fronteira agrícola contribui para redimensionar, a partir da presença de novas mercadorias, as relações de poder político nesses lugares, recompondonas em novas dimensões. As cidades dos notáveis (Santos, 1993) transformam-se, dessa forma, em centros de difusão dos sistemas técnicos sob o controle das empresas e de grandes produtores. Santos (1993:51), referindose a esse novo conjunto de cidades do Brasil agrícola, nos esclarece que:

"As cidades locais mudam de conteúdo. Antes, eram as cidades dos notáveis, hoje se transformam em cidades econômicas. A cidade dos notáveis, onde as personalidades notáveis eram o padre, o tabelião, a professora primária, o juiz, o promotor, o telegrafista, cede lugar à cidade econômica, onde são imprescindíveis o agrônomo (que antes vivia nas capitais), o veterinário, o bancário, o piloto agrícola, o especialista em adubos, o responsável pelos comércios especializados". 
Se, por um lado, a introdução da agricultura capitalista moderna nos cerrados piauienses confere aos moradores do urbano da região maiores oportunidades ao consumo de novos bens e de novos serviços, o que, por conseguinte, possibilita o surgimento de novas ocupações, por outro lado, esse fenômeno conduz à exclusão uma ampla parcela daquela população, aquela menos preparada para absorver o impacto dos novos processos da atual fase da modernização. Esses moradores não somente sofrem com os preços inflacionados das mercadorias que nos últimos anos são praticados, mas também são empurrados para a periferia dessas ainda pequenas cidades. $\mathrm{A}$ ocupação das franjas urbanas é feita, principalmente, por camponeses que deixaram - muitos expulsos pelo avanço da agricultura capitalista modernizada - as áreas rurais dos próprios municípios, e por outros que chegam de municípios vizinhos acreditando no discurso de prosperidade dos cerrados com a presença do agronegócio. Nesse sentido, as velhas formas urbanas que se metamorfoseiam diante das forças modernizadoras contemporâneas também se traduzem, assim como no rural, pela polarização das desigualdades. Enquanto determinados bairros nascem dotados mais completamente de equipamentos urbanos que atendem a uma parcela dos novos moradores, aquela de posse das riquezas produzidas pela agricultura moderna, aparecem, simultaneamente, as franjas urbanas empobrecidas. Elas são habitadas por trabalhadores - antigos pequenos proprietários, meeiros, posseiros, moradores de condição - que perderam suas casas e seus locais de produção, tornandose, freqüentemente, desocupados urbanos ou trabalhadores precarizados no urbano. Para esse grupo de piauienses dos cerrados, a expansão da agricultura capitalista moderna representou a perda de suas formas tradicionais de reprodução da vida e, ao mesmo tempo, a saída em busca da sobrevivência num urbano que se transforma e que também os marginaliza, na medida em que poucos deles conseguem lidar com os novos sistemas técnicos instalados nesses lugares. Essas manifestações são a expressão do colapso, da crise da socialização pelo trabalho. Além disso, aquela sociedade se torna cada vez mais sustentada no consumo de mercadorias industrializadas cuja aquisição ocorre apenas pela via do dinheiro, expressão da mobilização (expropriação) e imposição da forma-mercadoria. Tal fato agrava, sobremaneira, a situação 
dessa população que, diferentemente de outros momentos quando se poderia obter o sustento pelo seu trabalho na unidade familiar camponesa, somente consegue se manter com a venda de sua força de trabalho a qualquer preço. Às vezes essa possibilidade também inexiste, pois não se encontra quem queira comprá-la mesmo por preços aviltantes. Nesse caso, muitos se lançam numa nova modalidade de ocupação que surge nesse urbano expandido pelo agronegócio, qual seja, a de catadores de lixo, expressão crítica de uma mobilidade que não encontra ocupação e, portanto, como realizar a mercadoria força de trabalho, nesse contexto de crise. A presença de pessoas dedicandose à atividade de remover lixo em busca de algo que possa comercializar ou mesmo se alimentar, que é parte do cotidiano de uma parcela da população excluída das grandes cidades brasileiras, começa a se manifestar também nessas áreas que passam a se estruturar pelo consumo de bens industriais. Em Uruçuí e Bom Jesus, por exemplo, já se deparam com a questão do lixo enquanto problema ambiental, mas também enquanto questão que revela as mazelas que os processos de aceleração da modernização vêm produzindo naquela sociedade. As palavras de Araújo (2006: 121) deixam claro a presença de formas não-simultâneas na constituição do novo urbano do município de Bom Jesus:

"Sobre os serviços ambientais urbanos, há o aterro sanitário projetado em 1998 e instalado em 1999 que, na atualidade, funciona sem manejo adequado tanto no que se refere aos impactos ambientais decorrentes tanto da má localização, pois no seu entorno se aglomeram assentamentos humanos desordenados, além de bairros construídos pelo poder público, como a Cohab, por exemplo. Além da questão dos impactos no meio físico, verifica-se a questão da degradação humana no local, através da reprodução de práticas de cata de lixo pela população para a manutenção da própria vida, onde se registrou a presença de adultos e crianças catando os resíduos sólidos, em condições subumanas, ao mesmo tempo em que chegava o carro coletor de lixo para despejá-lo no chamado aterro, além da presença de animais domésticos que, na convivência com seres humanos, podem servir de vetores de doenças".

As antigas cidades piauienses que sofrem a intervenção de um outro tempo imposto pelo agronegócio, como Uruçuí e Bom Jesus, metamorfoseiamse, agregando as materialidades das grandes cidades, sem que, contudo, cumpram as outras fases percorridas pelo urbano em outros momentos históricos. Seus moradores se defrontam com dois tempos distintos mediados 
pelo conflito. As principais reclamações nas entrevistas com os representantes do agronegócio, durante $\mathrm{o}$ trabalho de campo, direcionavam-se para os trabalhadores piauienses contratados para exercer funções nas novas atividades desenvolvidas nas cidades. Nas palavras de tais entrevistados apareciam (implícita e explicitamente) a insatisfação com o ritmo empreendido por tais trabalhadores, muito aquém do que se desejava para tornar mais eficiente a produtividade do trabalho, seja no atendimento nos restaurantes, nas lojas de peças, ou em qualquer outra atividade. Os trabalhadores piauienses, por outro lado, posicionavam-se negativamente diante das exigências por parte de seus empregadores, quando esses cobravam mais agilidade nas ações.

Tal situação confirma o conflito de temporalidades que se aflora pelo encontro de duas concepções de mundo que se impõem em sentidos opostos. Oposição que também se coloca na forma como se separam no urbano os velhos e os novos moradores dessas cidades.

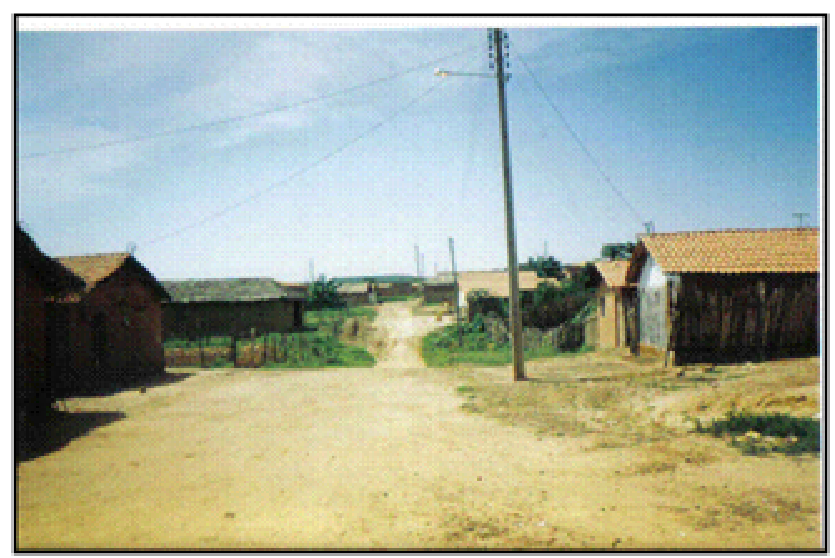

Foto 22 - Bamo pobre de uruyul oxpandido nos bitomos anos por conta da migracbo de antigos posseiros para o urbano. Foto do autor. janeino des 2006 .
No núcleo urbano de Uruçuí - que praticamente dobrou sua população nos últimos dez anos chegando a 30.000 habitantes, em 2005 (segundo estimativas da prefeitura) - são visíveis na paisagem vários loteamentos novos cujos moradores são antigos camponeses

expropriados que migraram para o urbano. É o caso, por exemplo, dos bairros Bela Vista e Aeroporto, na periferia do referido município, adensados rapidamente e de maneira desordenada com grandes carências de infraestrutura (foto 22). Neles, assim como em quase toda a área urbana de Uruçuí, faltam as condições mínimas de saneamento básico, tais como calçamento das ruas, tratamento de esgotos etc. Situações semelhantes ocorrem também no sítio urbano de Bom Jesus ${ }^{81}$. A mancha urbana deste município teve um

${ }^{81} \mathrm{Em} 2005$ (por conta da Lei Federal $n^{\circ} 11.107$ que trata da gestão associada de serviços públicos) iniciou-se nos municípios do sul do Piauí a primeira experiência seguindo as 
avanço considerável nos últimos anos com o surgimento de novos bairros (mapa 13), alguns deles com grande presença de moradores sulistas, como o bairro Judith Piauilino. Outros, entretanto, figuram-se apenas como loteamentos particulares, com pouca ou nenhuma habitação, mas para onde se projeta valorização em um futuro próximo. Destacam-se, nesse caso, o loteamento Alphaville e alguns outros designados de chácaras cujas áreas são limítrofes ao atual perímetro urbano, isso indica que a especulação imobiliária constitui, a partir de um determinado momento, a lógica que prevalece na expansão daquele urbano. Araújo (2006: 113), aponta que os meados dos anos 1990 representam um marco importante para o início de uma expansão urbana mais expressiva no município, conforme aparece em sua fala:

"A inexpressiva expansão do tecido urbano do município de Bom Jesus ocorrida entre os anos de 1985 e 1995, foi observada através da consulta das plantas urbanas da CEPISA E AGESPISA, respectivamente. Certamente naquele contexto, acredita-se que as mudanças, mesmo que modestas, tenham-se dado no âmbito interno aos limites do espaço urbano construído, não evidenciando expansão, mas provavelmente um adensamento dos equipamentos urbanos, seja habitacionais, comerciais, recreativos, dentre outros. No entanto, a partir do ano de 1995 torna-se evidente, mediante análise comparativa entre uma imagem de satélite e as plantas urbanas deste ano e de 2002 a dilatação do tecido urbano, principalmente na direção dos bairros cortados pela BR-135 (avenida Tiradentes), em especial o bairro Judith Piauilino, conhecido como Rodoviária, e o bairro Josué Parente, conhecido popularmente como Serra Pelada".

orientações da denominada Lei de Consórcios. Para o caso sul-piauiense formou-se o Consórcio Regional de Saneamento Básico - CORESA Sul do Piauí, com participação de 36 municípios sob a gerência de uma autarquia regional interfederativa cuja sede será em Bom Jesus. As principais funções de tal consórcio referem-se ao planejamento, a regulamentação e a fiscalização dos serviços de abastecimento de água e esgoto sanitário visando reduzir as carências de saneamento básico da região. Essa iniciativa poderá viabilizar novas formas de intervenção no sentido de melhorar as condições de saneamento das cidades sul piauienses, região cujos serviços de melhoramento sanitários sempre foram precários e que se agravaram com a expansão da área urbana a partir do advento do agronegócio. In: Montenegro, Lara - Revista Saneamento Ambiental, n 114 - Edição Especial, julho de 2005. 
Mapa 13: Evolução da Mancha Urbana do Município de Bom Jesus (PI) - 1995 a 2002

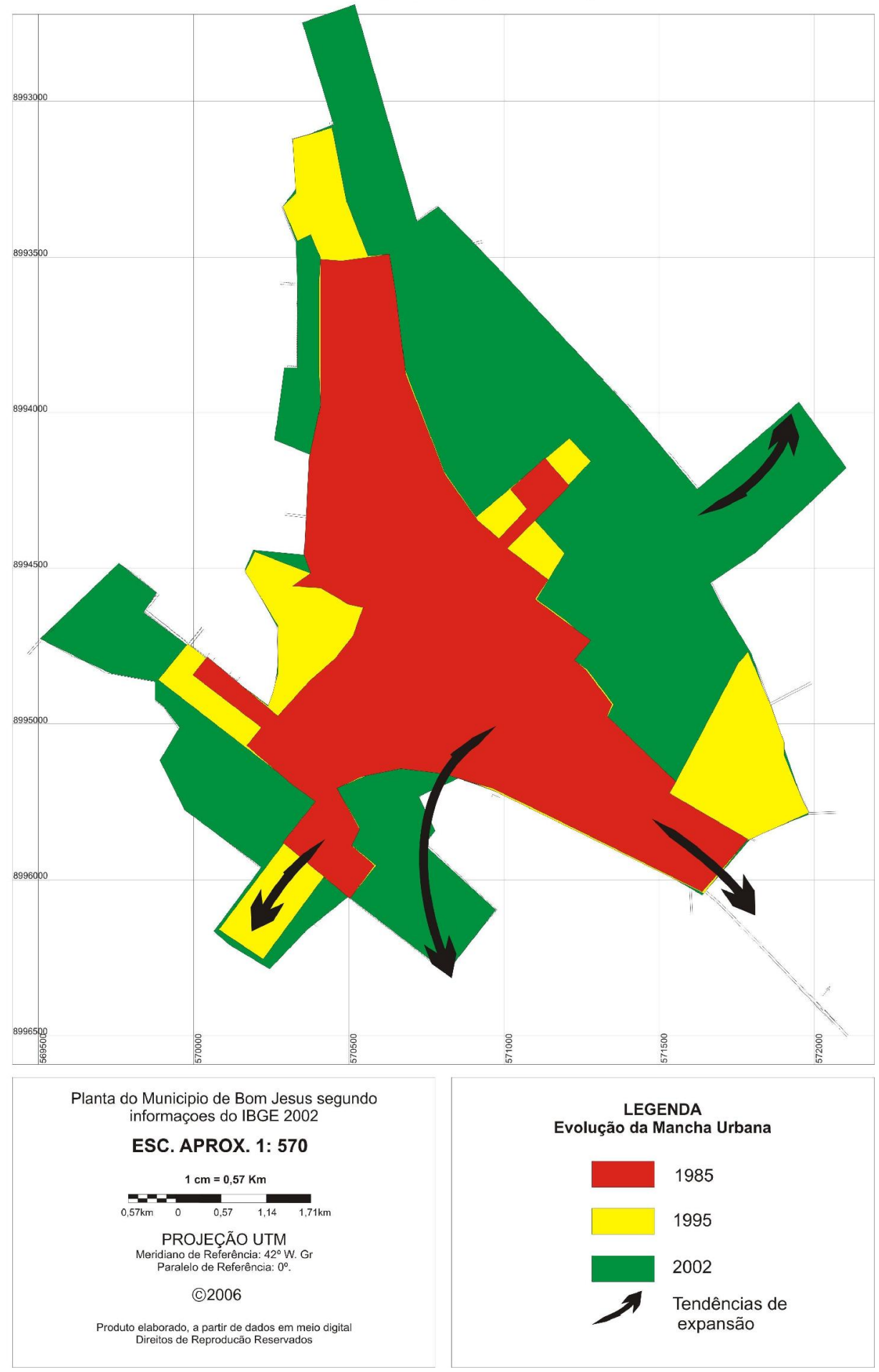

Fonte: Adaptado de ARAÚJO, Márcia Regina Soares de - 2006 
O poder público local possui um importante papel para que esse novo urbano se realize, na medida em que busca garantir não somente a infra-estrutura, mas também as bases legais para que ocorra a valorização do solo. A maneira como o Estado se torna legitimador desse processo se comprova, por exemplo, em Bom Jesus com a aprovação do Projeto de Lei $n^{\circ}$ 001/2006 de fevereiro de 2006, tratando da ampliação do perímetro urbano do município. A nova Lei é uma tentativa, nesse sentido, de afiançar aos novos espaços incorporados à malha urbana pela especulação imobiliária os mesmos serviços prestados pela administração pública às demais áreas do urbano pré-existente. Chama atenção em tal projeto de lei o texto impresso e assinado por um vereador (Jorge Luiz Santos Pereira) da Câmara Municipal de Bom Jesus, o qual apresenta sua justificativa para a necessidade de ampliação do perímetro urbano do município. Além das questões explícitas colocadas no que se refere às novas demandas por espaço no município, nas entrelinhas aparecem outras intencionalidades para tornar viável a presença do capital especulativo urbano, conforme podemos inferir a partir do texto que segue:

"Por vezes se tem discutido a necessidade de ampliação do perímetro urbano da cidade de Bom Jesus, haja vista a crescente movimentação migratória, a partir do desenvolvimento da agricultura (agronegócios) nos cerrados desta região. Hodiernamente, observa-se o fortalecimento e a confirmação desta cidade como o principal pólo de crescimento do comércio, indústria, prestação de serviços e, diga-se de passagem, excelência em educação e saúde, dentro das proporções engendrada numa região historicamente atrasada e esquecida pelo poder público. Por conta disso, tem-se aplicado investimentos maciços especialmente na construção civil (residencial, comercial, postos de atendimentos diversificados, etc.), o que tem gerado uma demanda vital por espaço territorial, consubstanciado também numa especulação imobiliária inexorável. De forma que, a possibilidade de se ampliar o perímetro urbano, faz-se urgente e necessário, no sentido de amainar os especuladores e colocar esta cidade na vanguarda de pólo irradiante de crescimento sustentável para todo o sul do Estado e possivelmente em todo o centro da Região Nordeste. Enfim, ampliar o espaço urbano a partir do lado direito do Rio Gurguéia, abre-se a possibilidade de num futuro Estado do Gurguéia, Bom Jesus se colocar como a cidade com maiores chances de ser a principal concorrente na disputa para sediar a futura capital do novo Estado. Por tanto, entendo que a maioria dos proprietários são favoráveis à mudança e que os ônus são compensados pelos bônus, a propositura que abraço é imprescindível e 
fundamental para o crescimento e maior desenvolvimento, sem valer-se de certa posição ou de circunstâncias para obter vantagens"

(Sala de Sessões, 20 de janeiro de $2006^{82}$ ).

Como se vê, as novas configurações urbanas dos cerrados piauienses diferem pouco de outras no contexto de expansão urbana dos cerrados nordestinos, como se observa para os casos de Balsas, Barreiras e Luis Eduardo Magalhães. Isso indica que estamos diante de um fenômeno cujas características de imposição capitalista se assemelham, fato que se explica pelo domínio da lógica da produção de mercadorias, manifestada também através da valorização da terra urbana.

Além de um novo urbano que se expande pelas antigas cidades dos cerrados piauienses, condicionado pelo processo de ampliação da produção do campo, esse mesmo fenômeno faz aparecer uma nova forma de produção de um outro tipo de urbano nessa área. A exemplo de Luis Eduardo Magalhães que, como vimos, apareceu nos platôs planos dos cerrados baianos pela instalação de migrantes sulistas, surgem, no sul do Piauí, núcleos habitados apresentando várias semelhanças com a formação do urbano daquele município e de muitas outras cidades que germinaram nas fronteiras agrícolas brasileiras, criadas para atender aos anseios dos representantes da agricultura capitalista moderna. Tentaremos a seguir identificar os principais vetores sócio-econômicos que suscitaram a formação desse novo tipo de urbano para o caso do sul do Piauí, e quais novidades são introduzidas nessa sub-região dos cerrados nordestinos no que se refere a tal questão.

\section{2 - A ocupação dos gerais piauienses para a formação de núcleos urbanos: o caso de Nova Santa Rosa}

Retomemos o grupo de migrantes gaúchos de Nova Santa Rosa, deslocados diretamente do Rio Grande do Sul para o sul do Piauí. É importante entender a presença dele nos cerrados piauienses porque, como dissemos,

\footnotetext{
${ }^{82}$ Texto retirado de cópia de documento que se encontra nos anexos da dissertação de mestrado
} de Araújo (2006). 
apresenta um perfil diferenciado do restante das outras famílias que chegou naquela área, tanto no que diz respeito à maneira de organização inicial do grupo que se destinaria ao Piauí, quanto ao tamanho da área individual adquirida e a forma de ocupação do lugar de morada.

Esse grupo chegou ao Piauí no ano de 1997 de maneira planejada sob o comando da Cotrirosa (Cooperativa Tritícola Santa Rosa), a qual conduziu o processo de organização/seleção das famílias no Rio Grande Sul e sua instalação no Piauí, permanecendo com elas os primeiros quatro anos, repassando, posteriormente, suas instalações para a Bunge Alimentos. O início da vida dessas famílias no Piauí se caracterizava, portanto, como um projeto coletivo privado de colonização cuja intenção era transformar pequenos agricultores gaúchos em produtores de grãos nos cerrados. Do início da presença da Cooperativa no Piauí à venda de suas instalações àquela multinacional, foi um período marcado por crises envolvendo a questão de gerenciamento financeiro, de relacionamento com os cooperandos e de dificuldades em lidar com as adversidades que aparecem num processo inicial de colonização, inclusive aquelas associadas às intempéries da natureza. O fato é que, após sucessivos problemas, a Cotrirosa abandonou o projeto de colonização no sul do Piauí, que incluía não somente transferir trabalhadores de uma região para outra, a fim de inseri-los na lógica da agricultura produtivista modernizada, mas também de construir um urbano a ser constituído predominantemente por seus pares, ou seja, o grupo de colonos selecionado pela cooperativa no sul do Brasil.

As famílias que participaram do processo de colonização do "Projeto Nova Santa Rosa", em sua maioria, consistem de pequenos produtores advindos do norte e noroeste do Rio Grande do Sul, principalmente da região de Santa Rosa. O projeto preliminar da Cotrirosa previa arregimentar 120 famílias gaúchas e transferi-las para o Piauí; entretanto, efetivamente se deslocaram cerca de 80 famílias, pois algumas delas compraram, mas não assumiram a área ou desistiram do negócio antes de efetivar a partida. Foram adquiridos para abrigar o grupo em torno de 50 mil hectares nos cerrados do Piauí, cujas terras se destinariam aos lotes agrícolas, a unidade de armazenamento de grãos, a uma agrovila e a uma 
futura cidade. Essa última receberia o nome de Nova Santa Rosa. Ao comprar o lote agrícola, com tamanho mínimo de 125 hectares, o colono receberia, financiado pela cooperativa, um outro, de um hectare, onde se instalaria uma agrovila e, ainda, um outro lote de tamanho $25 \times 35$ metros, na área reservada para o que constituiria a futura cidade. Os terrenos permaneceriam em nome da cooperativa até o momento em que o colono confirmasse o abatimento da dívida. Para formação do silo e do núcleo urbano foi reservado um módulo de 500 hectares, sendo que os lotes da agrovila pertenceriam somente às famílias pioneiras; no entanto, na futura cidade também haveria espaços disponíveis para os migrantes que chegassem posteriormente, aqueles não pertencentes ao núcleo inicial do projeto de colonização. As áreas para os lotes comerciais seriam doadas aos futuros empreendedores que quisessem se instalar na nova cidade.

Os problemas vivenciados no começo da colonização adiaram a execução do projeto da formação do núcleo urbano de Nova Santa Rosa. Atualmente há apenas o local destinado a esse fim, inclusive com a existência da planta na qual estão demarcados os arruamentos e a nomeação dos respectivos lotes dos colonos. Enquanto aguardam a efetivação do projeto, as famílias estão instaladas na agrovila que hoje já se configura em um outro núcleo urbano (foto 23), onde já existe o traçado do arruamento e as áreas destinadas às instalações de alguns equipamentos (escola, posto de saúde etc.). É nessa área que se delineia a germinação de uma urbanização. Apesar de não ter sido projetada para tornar-se um núcleo urbano, mas apenas uma área de moradia complementar temporária onde os colonos pudessem realizar pequenas criações de animais e hortas, a agrovila segue o padrão de outras cidades novas surgidas no percurso da agricultura capitalista moderna sob a liderança dos sulistas nos cerrados brasileiros. Adota uma lógica de ordenação urbana às vezes pensada ainda na região de origem, no Sul do Brasil, como é o caso de Nova Santa Rosa. Nela, projetam-se imensas ruas retilíneas formando quadras (foto 24 ), contrastando com as tradicionais estruturas urbanas das cidades piauienses. Para essas novas cidades se adota não somente um outro padrão de urbano, mas se reproduz na arquitetura das casas o estilo das antigas moradias, seguindo as tradições 
trazidas da Europa, mas também um padrão que está presente no traçado das ruas, na divisão dos lotes e, até mesmo, na ocorrência de uma certa seletividade dos moradores que habitarão esses lugares. Tal modelo de urbano se reproduz desde as primeiras cidades montadas pelos colonos imigrantes no Sul do Brasil e se irradia no caminho percorrido pelo grupo nas regiões de fronteiras agrícolas brasileiras. As características da formação do urbano no Rio Grande do Sul, de forte influência da colonização estrangeira, são mencionadas por Roche (1969: 218), como segue:

"É, sem dúvida, a planta que caracteriza as cidades pequenas do Rio Grande do Sul. Têm, todas, ruas retilíneas que se cortam regularmente em ângulos retos. Nas zonas colonizadas, a partir da segunda metade do século XIX, $O$ desenvolvimento das cidades se caracterizou da mesma forma. No lugar escolhido para o estabelecimento da cidade (sede), reservavam-se alguns lotes rurais (já geometricamente delimitado) e dividia-se-Ihes a área em quadrado iguais e contíguos, de 100 metros de lado, invariavelmente orientados para N-S e E-O. Alguns desses quadrados vinham a ser praças. Outros eram subdivididos em lotes urbanos de 20 × 50 metros. Esse urbanismo administrativo explica a regularidade da planta e o aspecto uniforme das cidades do interior do Estado. Essa mesma planta encontra-se em São Leopoldo, Caí, Venâncio Aires, Santa Cruz, Ijuí, Santa Rosa, por quase toda a parte. Raras são as cidades que têm outro traçado como Erechim, onde se adaptou o projeto de ruas e das praças à topografia (diagonais e semicírculos nas colinas, praças circulares). Mas, a distribuição dos lotes urbanos ali se efetuou com a mesma regularidade".

A reprodução de um urbano padronizado cria também, assim como na área de produção agrícola, uma certa homogeneização da paisagem dessas cidades. O novo urbano dos cerrados piauienses nasce com essa concepção. Ele se instala seguindo a orientação dos migrantes sulistas, que trazem consigo a marca da cultura européia. 


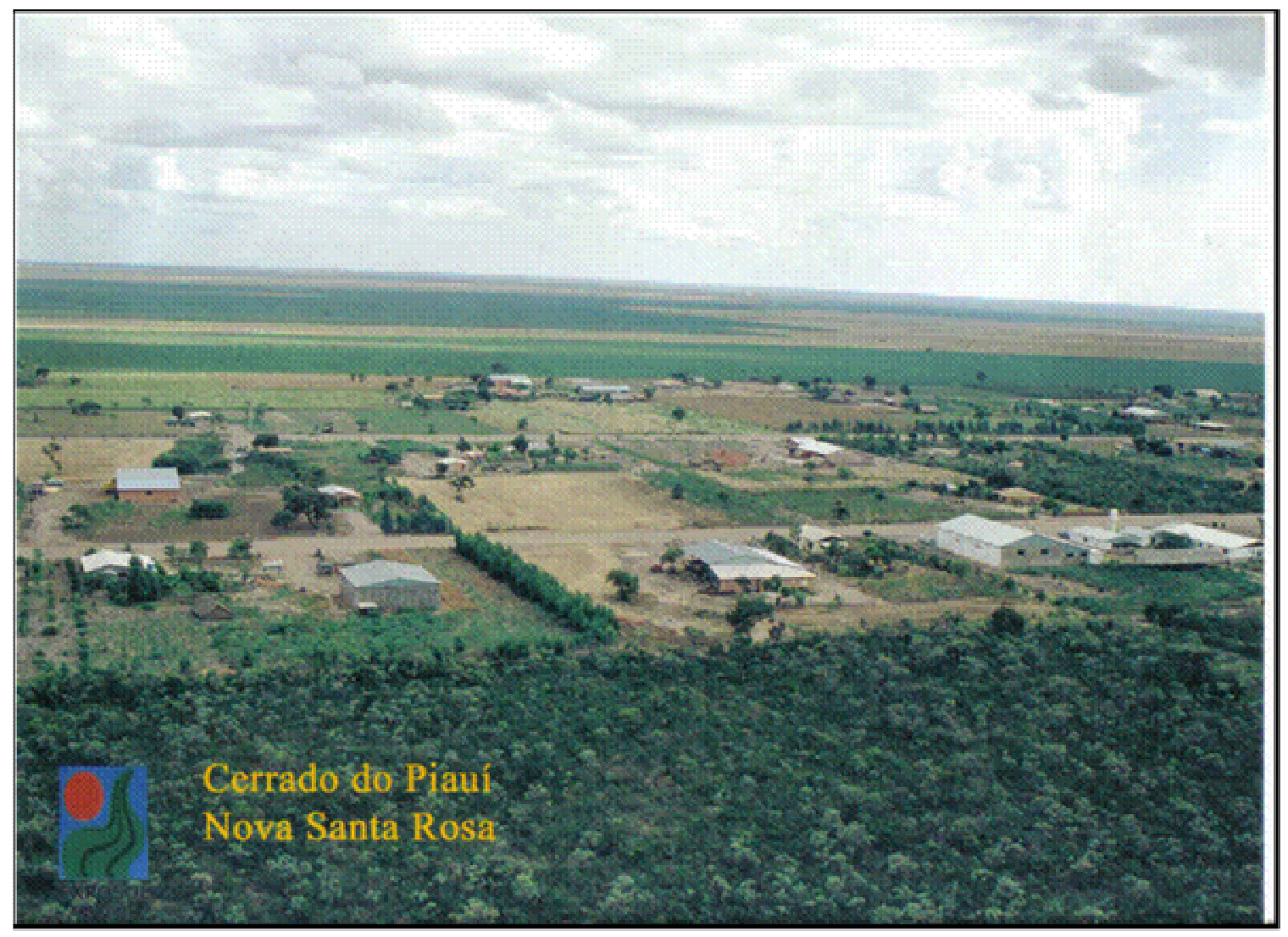

Foto 23 - Vista panorâmica da agrovila Nova Santa Rosa. Fotolab junho de 2003.

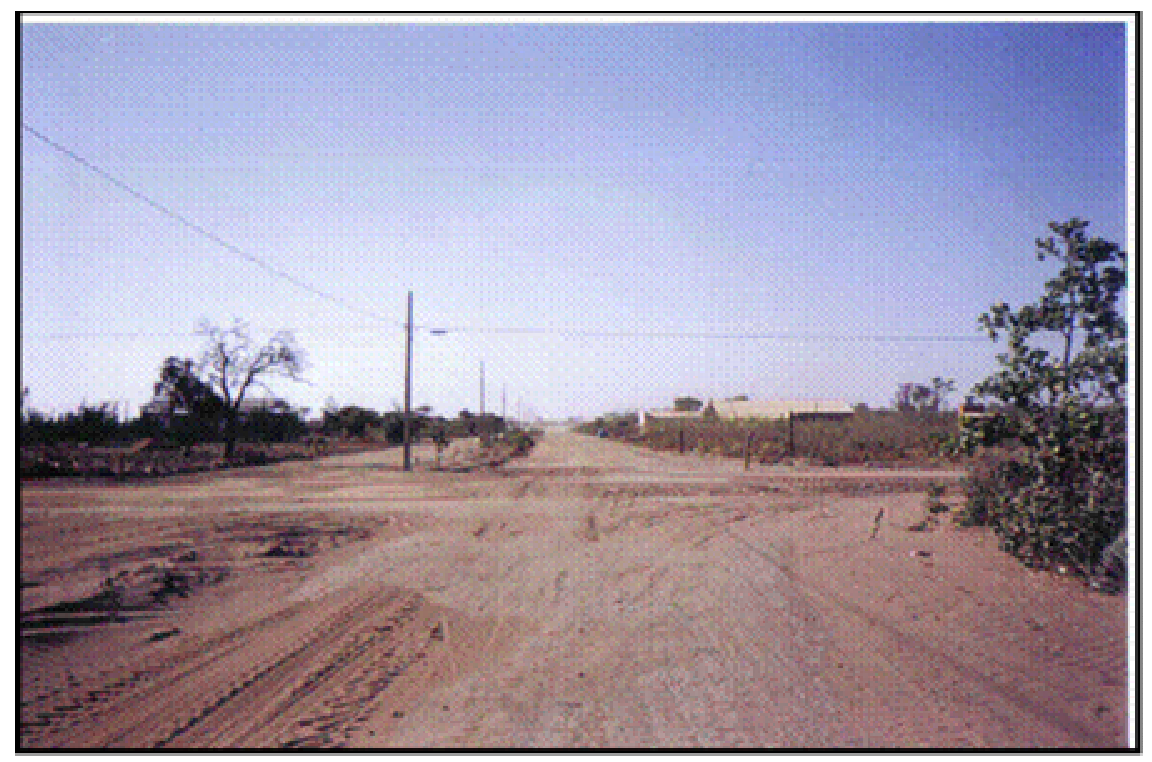

Foto 24 - Núcleo urbano de Nova Santa Rosa. Os traçados das ruas indicam uma futura urbanizaça seguindo o padrâ das novas cidades da fronteira agricola brasileira. Foto do autor, setembro de 2003. 
Com a instalação das famílias gaúchas em Nova Santa Rosa, inicia-se outra situação de uso dos cerrados piauienses, qual seja, a de destinar as terras das chapadas ou dos gerais para a formação de núcleos urbanos, algo inédito para as características de urbanização da região. Até então, os outros grupos de sulistas que chegaram ao sul do Piauí não adensavam um lugar específico dos platôs, mas a maioria optava por morar no urbano já existente, ou residir em suas próprias fazendas, ocorrendo, assim, a implantação de moradias dispersas. O que essa leva de migrantes sulistas - anterior à chegada dos migrantes da região de Santa Rosa - traz para os cerrados piauienses como inovação é o fato de aproveitar os domínios dos platôs para o uso agrícola, mas não despertava ainda o interesse pelo uso urbano dessa área.

A formação do núcleo de produção agrícola de "Nova Santa Rosa" inaugura efetivamente um novo processo de ocupação dos cerrados piauienses, não somente de ampliação do uso produtivo agrícola, mas de presença de estruturas urbanas. Nova Santa Rosa, dessa forma, segue um sentido inverso ao que se assistiu durante todo o percurso histórico anterior de formação do território piauiense. $\mathrm{Na}$ lógica de ocupação daquelas terras no passado (e isso é válido para o restante da formação espacial do sertão nordestino), como apontamos no capítulo 4, uma aglomeração urbana somente podia se concretizar levando em conta a presença de água. Esse era um fator de extrema importância para a escolha do sítio urbano. Por essa razão as cidades piauienses se concentraram, em sua grande maioria, próximas às vazantes, onde a maior umidade representava para os moradores do Piauí, desde o início da sua formação, um elo agregador do povoamento. Para a população dos cerrados imaginava-se improvável, antes desse processo de modernização contemporânea, nos domínios dos gerais, ocorrer qualquer fixação humana mais prolongada, a não ser nos baixões onde se anuncia a água. Mesmo porque nas adjacências dos vales úmidos localizavam-se os meios de produção da população, sejam as roças ou as fazendas de gado. Próximos aos poucos cursos d'água (eram onde se) germinavam os pequenos vilarejos, muitos deles, posteriormente, transformados em cidades. 
Os novos habitantes dos cerrados alteram substancialmente a regra exposta acima, impondo àquela área outra concepção de uso tanto no sentido de aproveitá-la para a produção de novas mercadorias quanto para fixar moradia. No contexto atual de ocupação do sul do Piauí, a água não significa mais um obstáculo fundamental que limita a prática da agricultura e nem a construção de moradias permanentes. Os sistemas técnicos se encarregam de resolver as limitações da natureza; a perfuração de poços contornou a ausência de água na superfície, buscando-na no subsolo a grandes profundidades. No caso de "Nova Santa Rosa", obtém-se água através de poços artesianos que chegam a 200 metros de profundidade, dali a água é bombeada para todas as casas e para a unidade de recebimento da Bunge Alimentos.

Superados os percalços naturais, o que se leva em conta agora para selecionar o local de um povoamento nos domínios dos platôs planos, como os núcleos que se observa surgir recentemente, é a sua localização estratégica; pela capacidade que o lugar possui para permitir maior fluidez das mercadorias produzidas. Ou seja, a escolha de uma área para estabelecer moradias é pronunciada segundo a proximidade das unidades de produção agrícola, no entroncamento de um corredor viário de escoamento ou, ainda, no entorno de uma grande empresa compradora de grãos. A moradia fica, nesse sentido, subordinada à produção. Mudam-se as relações de produção, mudam-se todas as instâncias de reprodução da vida.

O tipo de ocupação subordinado à produção agrícola moderna é o que se consolida recentemente nos cerrados piauienses, apontando para uma nova fase de sua organização espacial. A construção de núcleos de moradias nos gerais é parte das novas formas espaciais que se manifestam no sul do estado. Apesar de ainda embrionários, elas indicam a ocorrência de novos padrões de urbanização, na medida em que seguem estilos dos grupos sociais que ali desembarcam, representados, sobretudo, pelos sulistas. Além de Nova Santa Rosa, surgem outros núcleos de aglomeração humana nos cerrados piauienses cuja organização se reveste de outras intencionalidades. Destacam-se, por exemplo, os loteamentos "Portal dos Cerrados" (ou Cacique) e "Nova Uruçuí". Esses dois 
loteamentos estão localizados fora do núcleo urbano de Uruçuí e destinam-se, principalmente, aos representantes do agronegócio, aqueles com (posse de) maior poder aquisitivo. Nesse caso, a área dos loteamentos contém os requisitos necessários de urbanização apresentados pelos agentes imobiliários como um dos elementos que os diferencia da antiga área urbana de Uruçuí (foto 25 e 26).

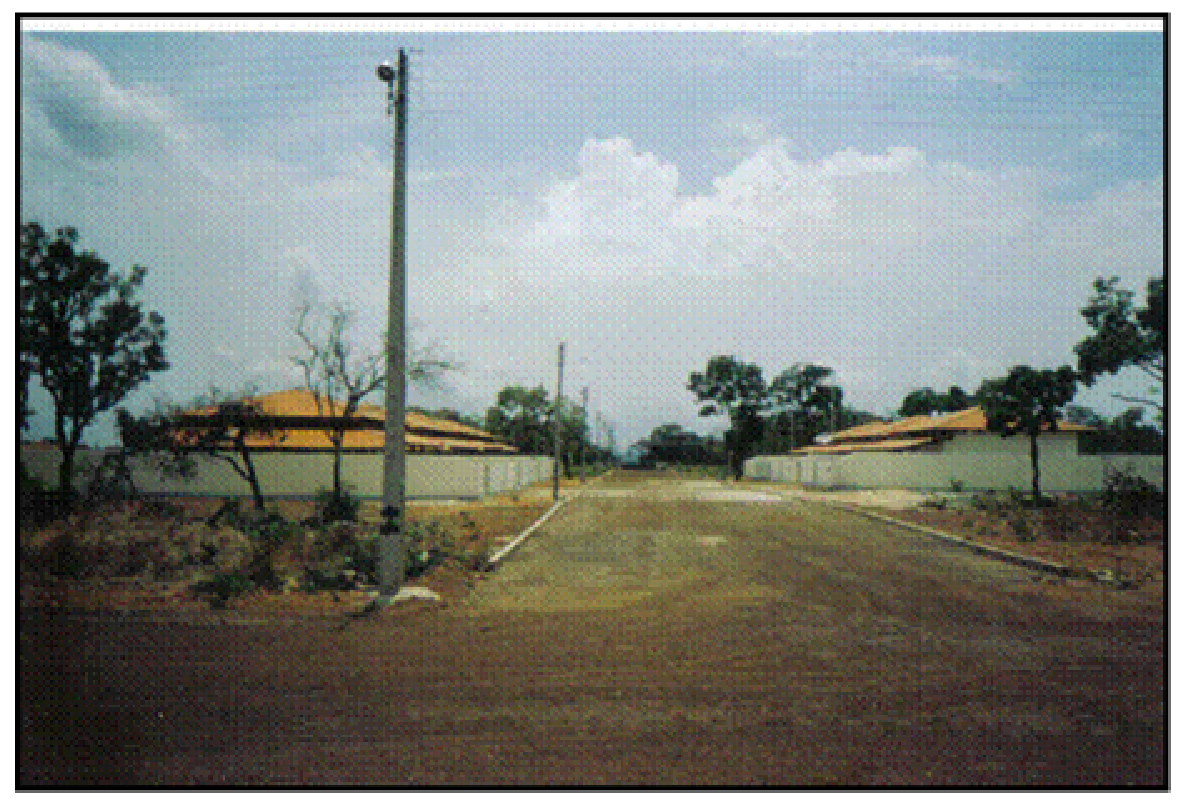

Foto 25 - Loteamento Portal dos Cerrados. Foto do autor, setembro de 2003.

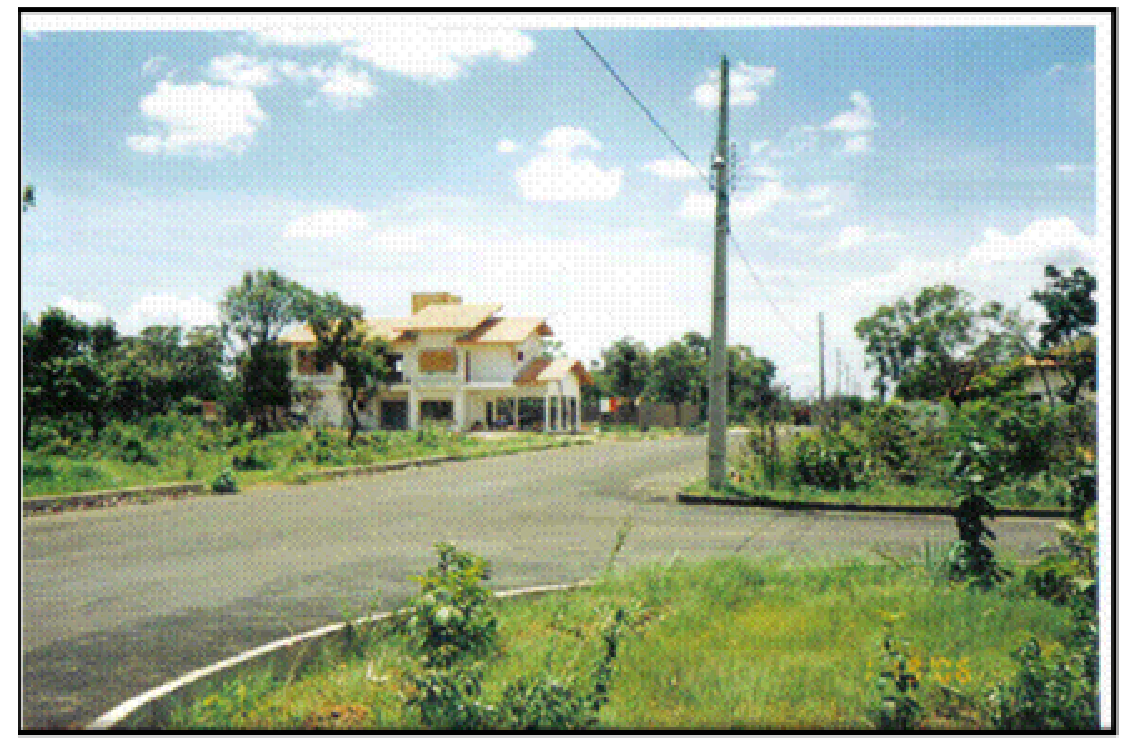

Foto 26 - Loteamento Portal dos Cerrados em fomaça, habitado por representantes do agronegocio. localiza-se cerca de 25 quilometros da sede do municipio de Urugui. Foto do autor, janeiro de 2006. 
O loteamento Portal dos Cerrados (conhecido popularmente por loteamento Cacique por encontrar-se nas cercanias do posto de combustível que pertence ao grupo econômico Cacique) foi lançado pela empresa imobiliária Central Logística no ano de 2002, em Uruçuí, para atender aos novos habitantes. Sua localização ocorre numa estrada de entroncamento com ramificações para a fábrica da Bunge Alimentos e para outros municípios do sul do Piauí (Bertolínia, Ribeiro Gonçalves e Baixa Grande do Ribeiro) e do Maranhão (Benedito Leite e Balsas). Antes da instalação de tal loteamento já existia ali o citado posto de combustível, cujo movimento de caminhões atualmente é intenso por conta das demandas da Bunge Alimentos (foto 27). Posteriormente foram instaladas também nas proximidades do posto algumas lojas de maquinários modernos, produzindo uma quase autonomia comercial em relação ao primeiro núcleo urbano de Uruçuí, distante cerca 25 quilômetros.

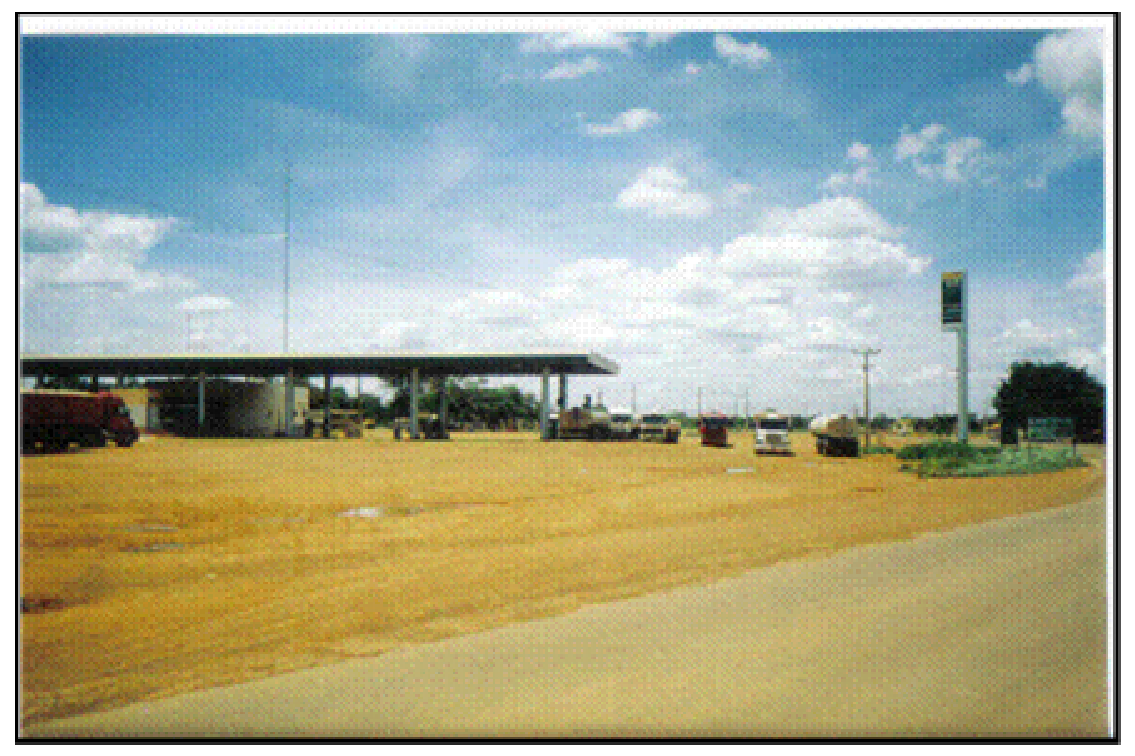

Foto 27 - Posto Cacique - no seu entorno ocome grande movimento de caminhoses por conta da presença da Bunge Alimentos, instalada nas proximidades. Foto do autor. janeiro de 2006. 
O Portal dos Cerrados é anunciado como um loteamento modelo e inédito no sul do Piauí, com lotes em traçados ortogonais (ver croqui, figura 01) que são adquiridos por funcionários da Bunge, mas também são vendidos para outros novos moradores dessa área, sobretudo sulistas. $O$ projeto urbanístico acompanha o padrão do estilo de vida que se consolidou na sociedade urbana contemporânea; isto é, os espaços de vida são concebidos separados do urbano pré-existente, e onde há pouca interação social com os demais moradores da cidade. Em outras palavras, os moradores mais ricos se auto-segregam (Seabra, 2004), como forma de evitar a convivência com os mais pobres. No Portal dos Cerrados se desenvolve um modo vida que pouco se assemelha ao que ocorre a alguns quilômetros dali, onde se localiza a sede da cidade de Uruçuí e onde acontece o movimento das pessoas estabelecendo um cotidiano pautado pelo encontro, produzindo daí suas diferentes dimensões. Nas novas áreas de moradias distanciadas, espacial, social e economicamente, do tradicional urbano, quase não há encontro de pessoas, as ruas permanecem vazias de gente durante todo o tempo, as casas são todas de alto padrão comumente cercadas de muros, permitindo maior isolamento e menos contato com o outro morador vizinho. Os deslocamentos até a sede do município somente ocorrem para certas necessidades burocráticas, como ir ao banco, ao cartório etc. 
Figura 01 - Croqui do Loteamento Portal dos Cerrados

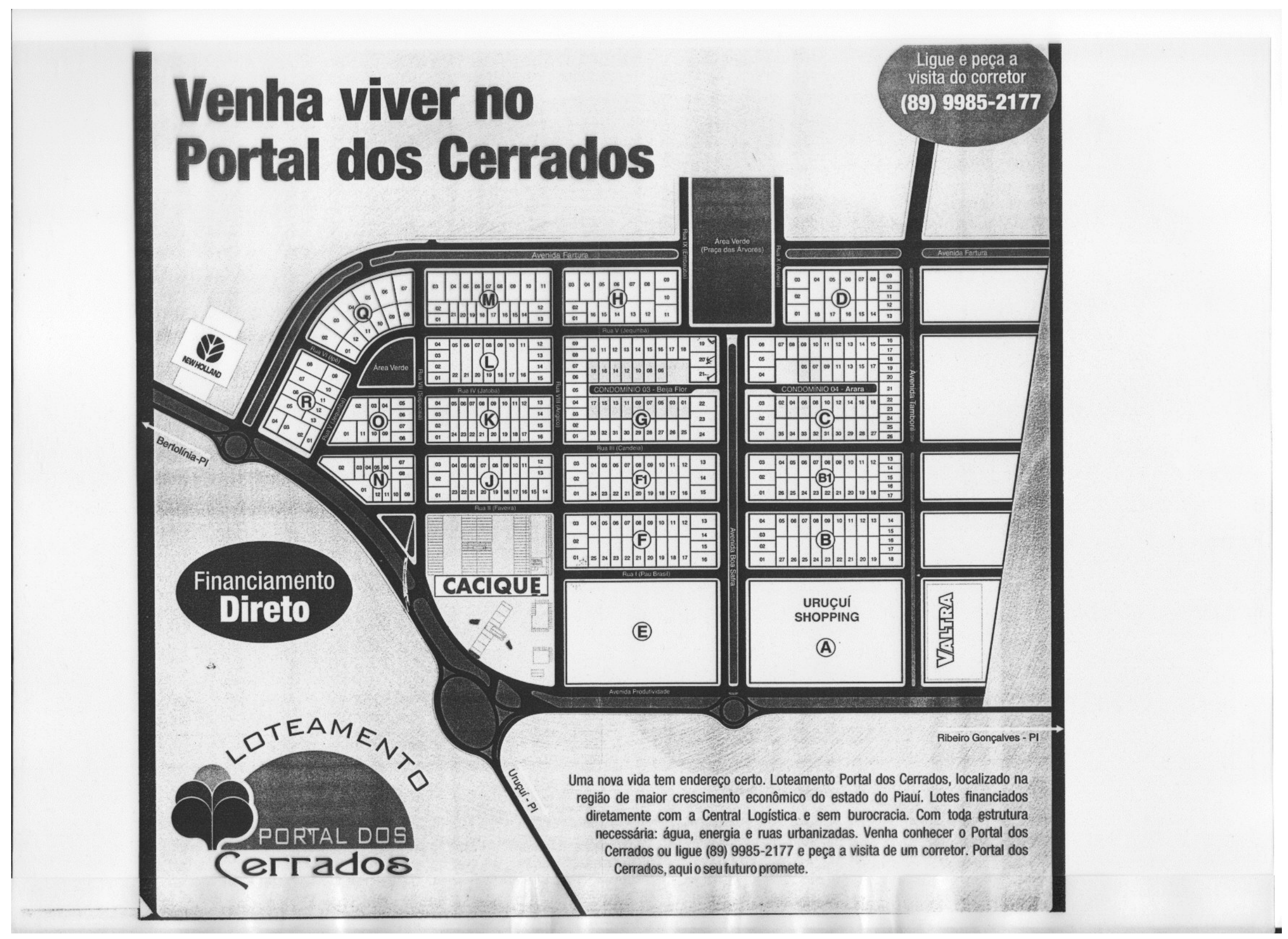


A fragmentação desse urbano, que registra a história recente da metrópole, também passa a ocorrer nas médias e pequenas cidades do interior do Brasil, sobretudo naquelas que sofrem maiores interferência da monetarização. Nesse sentido, as palavras de Seabra (2004:182) são esclarecedoras da forma como se generaliza na sociedade capitalista moderna um modo de vida urbano. A autora, ao apontar os caminhos das discussões que realizará no seu texto, a respeito desse fenômeno relata:

"O principal a ser considerado nesse breve ensaio é que, na urbanização contemporânea, o cotidiano emerge para análise na metamorfose das formas de uso do tempo vivido; que o cotidiano urbano prolonga e explicita o sentido da urbanização capitalista pela generalização de um modo de vida no qual foram sendo aprofundadas as separações no âmbito da vida social".

Projeta-se para o loteamento Portal dos Cerrados uma situação de autosuficiência, na medida em que ele contará em breve com escola, mercados, shopping-center etc. Os discursos de seus moradores mais endinheirados, em defesa dos estilos de vida do novo urbano, são os mesmos os adotados pelos das metrópoles, tais como os de usufruir áreas seletivas contendo uma suposta melhoria na qualidade de vida, principalmente pelo fato de se criar em seus habitantes a sensação de que vivendo separados das antigas áreas urbanas estariam mais protegidos de algumas das mazelas ali encontradas, como é o caso da segurança. Embora a realidade demonstre, muitas vezes, que a questão de fundo não seja essa, mas a de construir os limites que permitem diferenciar - numa sociedade que se pauta pela distinção social - os de posse de capital e os despossuídos das riquezas. Novamente Seabra (2004: 194) nos dá uma excelente contribuição a respeito desse distanciamento espacial e social que ocorre no novo urbano:

"A auto-segregação nada mais é do que um recurso estratégico que visa administrar a separação consumada nos territórios do urbano. Em decorrência, a apropriação, que é fruição de tempo e de espaço sob determinações e imperativos do movimento de propriedade em geral, é coagida, restringida, permitindo às experiências no âmbito do viver apenas o nível do irrisório, dado o fato que nada pode substituir aquilo que foi a maior de todas as riquezas: a cidade". 
O urbano sul piauiense - que até recentemente possuía apenas uma única centralidade que articulava as partes e para onde todos convergiam torna-se agora disperso. Deixa de existir uma convergência de seus moradores para um lugar onde havia encontro de todos, pois o centro urbano era o lugar do mercado, da feira, do cartório, da igreja etc. Surgem, nesse sentido, novos centros que se impõem com mais vigor, agora sob o comando das empresas, como nos relata um migrante sulista sobre a formação de novos núcleos urbanos em Uruçuí, os quais ganham centralidade em função da Bunge:

"A gente não sabe se daqui a cinco ou seis anos vai continuar isso. Acho que Uruçuí vai nascer mais em função da Bunge. Tem um novo loteamento sendo criado lá. A cidade de Uruçuí vai ficar uma cidade velha, e a cidade nova vai ser esse novo loteamento".

(Laurindo Allebrando. Entrevista concedida em setembro de 2003).

Esse novo urbano piauiense, que surge pelo poder que as empresas e/ou os produtores da agricultura capitalista possuem em comandar as ações transformadoras do espaço, não é capaz, entretanto, de apagar as marcas que se sedimentaram no processo histórico de construção desses lugares. Muito antes de se tornarem a expressão da modernização contemporânea no sul do Piauí como portadoras de mercadorias para atender os representantes do agronegócio, as cidades já existiam enquanto espaço de manifestação do cotidiano da população local. Algumas delas foram fundadas ainda no período inicial de colonização do Piauí, no século XVIII, eram pequenas aglomerações urbanas nascidas pelo avanço da pecuária no sertão piauiense que depois foram elevadas à categoria de vila e cidade. Bom Jesus, por exemplo, nasceu enquanto povoado no início do século XIX, 1805, e como a maioria das aglomerações urbanas do Brasil colônia, foi fundada mantendo uma forte ligação com o universo religioso e as práticas que daí emanam, dentre elas as novenas e os festejos para homenagear o Senhor Bom Jesus da Boa Sentença (Raposo, 2004, apud Araújo, 2006). Naquela ocasião, a construção da capela era o primeiro ato simbólico para se constituir em um lugar de morada, 
sob o imã da igreja é que o urbano se expandia. Em 1855, Bom Jesus transforma-se em vila e, em 1938, em cidade. No caso de Uruçuí, nasce como povoado no século XIX, mas em 1902 se constitui numa sede administrativa no sul do estado. Nessa mesma trajetória seguem várias cidades dos cerrados piauienses. Tal fato demonstra, portanto, que os espaços urbanos dos cerrados piauienses já estavam consolidados antes do atual processo de aceleração da modernização. O que se coloca como novidade para essas cidades, sobretudo Bom Jesus e Uruçuí, é a imposição de um outro sentido de construção do urbano, agora sob o controle dos agentes sócio-econômicos representantes da agricultura moderna, que se organizam essencialmente pela lógica do dinheiro. O tempo que prevalece, portanto, atualmente, é o da produção de mercadorias para a exportação, a velocidade nas transformações do urbano sul piauiense obedecerá agora a esse tempo.

\section{3 - Os gaúchos do núcleo urbano de Nova Santa Rosa}

Uma das características fundamentais presentes no imaginário das pessoas colocadas em movimento pelo capital é a de carregarem consigo invariavelmente o desejo de se depararem com oportunidades de ganhos econômicos que suas antigas áreas de moradias não eram mais capazes de oferecer. Partem contagiadas por uma euforia de se encontrarem com um cenário que dê conta de responder aos seus projetos de mudança para uma outra condição social. A esperança de uma melhoria de vida é um elemento a se considerar no processo de deslocamento dos trabalhadores. Estes aceitam migrar porque projetam serem também consumidores de bens (Gaudemar, 1977). No Brasil, essas circunstâncias favoreceram a mobilização e estavam no horizonte dos migrantes que se lançaram para os novos espaços incorporados ao capital. A população mobilizada foi responsável pelos novos arranjos que se sucederam no território brasileiro durante toda a sua formação. As palavras de Monbeig (1984:125) a respeito da ocupação do oeste paulista no início do século $X X$ são reveladoras das mudanças espaciais que acompanhavam esse movimento. A força de trabalho mobilizada 
e o café representavam as mercadorias estimuladoras da marcha de pessoas em direção àquela região produzindo grandes transformações no seu percurso, como nos esclarece o autor:

"Desde que tomou pé nos planaltos ocidentais, prosseguiu a vaga pioneira em sua marcha infatigável, sacudida pelas crises econômicas, aceleradas às vezes pelo jogo das circunstâncias políticas mundiais. Incessantemente engrossada por elementos novos, a multidão dos plantadores e dos pioneiros não cessou em progredir, mais ou menos depressa, mas sem fatigar-se. Testemunham avanços sucessivos as cidades, que se sucedem como contas de um rosário, ao longo das ferrovias. Por toda a parte, traz a paisagem a marca dessa ofensiva contínua, nos restos de florestas que subsistem, sobre os solos talados por essa cultura devastadora. Cada fase acarretou algo novo, que não desapareceu com a progressão. História bem curta, mas que cumpre conhecer, seguindo episódios da marcha pioneira, para compreender como se elaborou o seu mundo, tal como hoje se nos apresenta".

Guardadas as proporções de intensidade das mudanças empreendidas nas formas espaciais e o hiato de tempo entre as ocorrências, o cenário apresentado acima poderia ser descrito em condições semelhantes para o fenômeno de mobilização do trabalho e do capital no Centro-Oeste brasileiro nos anos 70 e, mais recentemente, nos cerrados nordestinos. Tal situação nos revela, assim, um território cuja formação possui uma inerente relação com as grandes marchas migratórias de trabalhadores a serviço do capital.

Se o café dominou o processo de avanço da fronteira desde meados do século XIX até as primeiras décadas do século passado, produzindo ao longo de seu percurso novas territorialidades, a partir da década de 1960, no entanto, entra em cena, como vimos, uma outra cultura não menos devastadora: a soja. Essa cultura também se vê favorecida por circunstâncias político-econômicas mundiais. Mudam o momento histórico e as áreas de incorporação de novos processos de modernização, mas as estruturas de expansão econômica seguem as mesmas, por vezes com participação dos mesmos grupos de personagens. Trata-se aqui da continuidade de um processo ainda em franca expansão de acumulação que deixa suas marcas na formação contemporânea do território brasileiro, principalmente pela destruição de formas tradicionais de organização de modos de vida e pela imposição de formas homogêneas sócioespaciais, adaptadas à fluidez do mundo da mercadoria. 
Se a marcha para o povoamento brasileiro constituía-se edificadora, ela também era dolorosa para aqueles grupos de migrantes menos favorecidos. Estes são os que comumente tomam a dianteira nesse processo e sofrem as conseqüências por cumprir tal papel. À frente deles, às vezes, somente os especuladores de terra, os quais estabelecem uma ampla rede de articulação com diversos grupos econômico-sociais nas distintas instâncias políticas e jurídicas locais. A construção desses laços é o que possibilita, nesse sentido, a apropriação privada das terras, lançadas ao mercado na medida em que adquirem valorização.

No Piauí, apesar das terras do domínio dos gerais já terem uso como o descrito anteriormente, eram terras com pouca gente, mas não com pouco uso. Não cabe aqui, dessa maneira, a idéia de frente pioneira, discutida por Monbeig e outros estudiosos sobre a ocupação de terras brasileiras para o capital. A ocupação dos cerrados piauienses nos termos que ocorrem atualmente mereceriam outras denominações. Apesar de recusarmos a idéia de pioneirismo como a que se atribuiu para outras áreas - que merece também ressalvas haja vista que eram terras habitadas por populações nativas - há também ali um universo de novidade nas características de ocupação, no sentido da abertura de um certo domínio de áreas para o uso do capital.

Essa etapa de ocupação, no entanto, num primeiro momento, não é realizada diretamente pelos principais agentes do capital, mas, em muitos casos, por pessoas comuns que incorporam a ideologia do capital, e que personificam o capital. A esperança de acesso à propriedade privada da terra $\mathrm{e}$ a possibilidade de acumular riquezas levam os migrantes a tomarem a dianteira na abertura dos espaços para transformá-los em bases de produção de mercadoria. São esses indivíduos anônimos que vão se defrontar com as adversidades que o lugar apresenta para construir o território de fluidez do capital. Eles são aproveitados também para aumentar os lucros dos especuladores imobiliários e os de outros agentes econômicos que se reproduzem pela exploração daqueles que não possuem qualquer alternativa senão a de se lançar às amarras do capital. Essa 
cadeia de exploradores do trabalho alheio é mencionada por um dos migrantes gaúchos que adquiriu aproximadamente 400 hectares nos cerrados piauienses:

“(...) Nós não conseguimos pagar a terra à vista, esse ano a gente pagou cinco mil saco de soja para o dono da terra. Isso também foi um dos problemas, é que tinha quatro que ganharam em cima dessa terra: foi o colonizador, o cara do escritório de quem a terra veio, o presidente da cooperativa e o dono da terra. Quatro pessoas, e ai a terra se tornou cara porque na verdade aqui a terra valia em torno de dois sacos de soja, nós pagamos dez, doze, ai ainda botaro $40 \%$ de juros em cima porque atrasou o pagamento".

(A.S., gaúcho de Santa Rosa, morador em Nova Santa Rosa. Entrevista concedida em setembro de 2003).

Os moradores de Nova Santa Rosa se inserem nesse contexto. Nas perguntas dirigidas aos colonos gaúchos que tentavam a sorte nos cerrados piauienses questionamos porque eles deixaram suas moradias lá no Sul mesmo que elas não fossem muito luxuosas, visto que em sua maioria eram pequenos produtores, mas todos apresentavam aparentemente uma situação econômica estruturada para os padrões de vida da maioria dos brasileiros, residindo próximo a cidades com equipamentos urbanos que supriam minimamente suas necessidades - para viver o universo incerto de ocupação no sul do Piauí. As repostas se direcionaram, predominantemente, para a questão da busca de oportunidades, de acumular ou de garantir o direito às gerações futuras a um pedaço de terra que pudesse garantir sua continuidade como produtor agrícola. Transparece, nesse sentido, no discurso desses migrantes a visão de que eles adotaram uma decisão meramente individual, a de buscar oportunidades em outro lugar, pois se projeta na área de destino a possibilidade de mudança de estrato social - portanto, a idéia de exercer o direito de liberdade de locomoção como a procura de benefícios para si. A verdade, todavia, é que sua atitude de se colocar em movimento revela mais os anseios do capital de tornar o trabalho do grupo mobilizado a fim de disponibilizar seus corpos ao serviço da produção do valor. O colono se esforça, assim, para colocar à disposição do mercado mais mercadorias. 
As famílias que participaram do projeto "Nova Santa Rosa" eram oriundas da região de Santa Rosa, todas elas de pequenos e médios produtores daquela região, como fica claro no relato que segue:

"Lá embaixo tudo era pequeno. A gente não tinha mais espaço para a gente se expandir. A gente era de pequenos agricultores e não tinha outra saída a não ser procurar um lugar onde tivesse terra barata. E lá a gente já morava em três famílias, era eu, meu cunhado e meu sogro. Então era praticamente uma parte só, trabalhávamos juntos. Era tudo pequeno. Lá era em torno de trinta hectares dividido por três".

(Laurindo Aldebrando, gaúcho de Santo Ângelo, morador em Nova Santa Rosa. Entrevista concedida em setembro de 2003).

O depoimento acima traz indícios importantes das transformações espaciais pelas quais passou o noroeste do Rio Grande do Sul onde se encontra Santa Rosa. As terras daquela região tornaram-se escassas para os pequenos produtores agrícolas, espremidos pelo avanço do agronegócio, principalmente pelas lavouras de soja, nessa região que foi por onde começou a produção dessa commodity no Rio Grande do Sul (Dietz, 2006). Tal fato constitui um dos motivos para o deslocamento de membros das famílias camponesas para o Piauí. A desarticulação das unidades de produção e a limitação de acesso à terra a novas gerações de agricultores transformou a região de Santa Rosa em um dos importantes focos de mobilidade dos migrantes em direção às novas áreas de colonização em vários estados brasileiros e em países como o Paraguai. Nesses lugares, inclusive, formaramse municípios que fazem referência ao lugar de origem dos migrantes, como é o caso, por exemplo, de Nova Santa Rosa, no Paraná, e Santa Rosa e Santo Cristo, no Paraguai (Dietz, 2006) ${ }^{88}$.

A transferência dos colonos de Santa Rosa para o Piauí ficou a cargo da Cotrirosa, empresa que se encarregou de realizar os levantamentos nos cerrados nordestinos dos lugares propícios para receber o grupo e de negociar o preço da propriedade a ser adquirida. A seleção das terras do sul do Piauí

\footnotetext{
${ }^{88}$ A instalação de migrantes oriundos da região de Santa Rosa em vários lugares do território brasileiro suscitou a criação de linhas de ônibus ligando as áreas de fronteiras agrícolas do país ao noroeste do Rio Grande do Sul (Dietz, 2006). Do oeste baiano (Barreiras e Luis Eduardo Magalhães) e do sul do Maranhão (Balsas) partem diariamente ônibus, de mais de uma empresa, com destino a Santa Rosa.
} 
para a instalação do grupo deveu-se à posição estratégica do lugar: localiza-se numa relativa proximidade de várias cidades importantes nordestinas, principalmente das capitais, pois num raio de 1500 quilômetros é possível atingir todas elas; maior facilidade de acesso ao Porto de Itaqui, se comparado ao de outras regiões do interior do Brasil produtoras de grãos; já se projetava naquele momento a presença de um grande corredor de escoamento que faria conexão com o sul do Piauí: tratava-se da ferrovia Transnordestina. Além disso, a cooperativa ficou encarregada de organizar a seleção das famílias participantes do projeto de colonização agrícola, executar a divisão dos lotes e elaborar o plano urbano do que seria a futura cidade. $O$ intuito era incentivar a esse colono adquirir lotes de, em média, 400 ha de área útil. Os que não podiam comprar as áreas com essas dimensões foram aconselhados pela cooperativa a se organizarem em grupo para tornar possível o empreendimento. Muitos dos produtores se associaram em grupos de dois, três e até cinco sócios, sendo que uma ou duas famílias migrariam para o Piauí e o restante permaneceria no Sul oferecendo as assistências necessárias aos seus sócios e/ou familiares que se transformariam em colonos nos cerrados. Os lotes foram adquiridos pelos colonos diretamente do vendedor a um preço, médio, de 10 sacas de soja por hectare, enquanto no sul pagava-se de 300 a 400 sacas por hectare. Cabia também à cooperativa organizar o planejamento urbano da cidade e da agrovila e vender os lotes para os associados ou os que chegariam, perfazendo, aproximadamente, 1.200 lotes. Além de construir um silo para armazenar a produção dos colonos.

O grupo de colonos selecionado é composto predominantemente de jovens, normalmente recém-casados, mas encontram-se também pessoas mais velhas, numa faixa etária acima de quarenta anos. Freqüentemente, os mais velhos seguiram para o Piauí acompanhando os filhos, para onde mudou toda a família ou apenas alguns de seus membros, os demais permanecendo no Sul. 
"Olha, na verdade, nós somos em três irmãos, aqui nós temos uma parceria aqui. Inclusive nós trouxemos nossa mãe. Vendemos tudo lá no sul e conseguimos passar para 500 hectares aqui. Nós entramos juntos também nesse comércio que temos aqui, o restaurante, a pousada. Mas, lá no sul ficou mais um irmão morando lá. Ele ficou meio com o pé atrás pra vim praqui, ele gosta de lá. Então a gente chegou aqui só em três irmãos".

(Adilson Jacob, gaúcho de Santa Rosa, morador em Nova Santa Rosa. Entrevista concedida em setembro de 2003).

"Eles firmaram a terra aqui, o filho veio olhar, o genro também, mas eu mesmo nem tinha vindo olhar, mas ai como eles iam vim, a gente não ia ter sossego ficar lá, né".

(Anildo Schored, gaúcho de Santa Rosa, morador em Nova Santa Rosa. Entrevista concedida em setembro de 2003).

Outra característica dos colonos de Nova Santa Rosa, que diferencia de muitos outros sulistas que se instalaram nos cerrados piauienses, diz respeito ao fato de serem médios e pequenos proprietários. Aumentaram seus domínios em comparação aos que possuíam no Rio Grande do Sul, mas suas terras são muito inferiores ao tamanho das propriedades de outros sulistas instalados no Piauí, principalmente os que passaram por uma outra fronteira agrícola. Além disso, a maioria deles realiza pela primeira vez uma migração para outra região do país, o que torna esse processo de deslocamento mais doloroso para alguns membros do grupo.

Antes da mudança definitiva para a área selecionada nos cerrados piauienses houve, em 1997, uma visita do grupo aos cerrados piauienses, através de excursões de ônibus. No início de 1998 desembarcam no Piauí os primeiros colonos, acompanhados, progressivamente, dos demais no decorrer daquele ano e do seguinte.

Os relatos dos migrantes sobre a ocupação das terras piauienses pouco se diferenciam dos de colonos que viveram essa mesma situação em áreas de fronteira agrícola ao longo do século $X X$ nesse país. Desembarcaram numa área onde o núcleo urbano piauiense mais próximo é a cidade de Palmeiras, que se localiza a uma distância de um pouco menos de 100 quilômetros, cujos 
ramais de ligação são precários, o que dificultava qualquer contato com maior freqüência a equipamentos urbanos mais estruturados. Antes da construção das moradias definitivas, instalaram-se, provisoriamente, em barracas de lona preparadas ainda no Rio Grande do Sul para agüentar o calor e as outras intempéries climáticas. A água disponível naquele momento encontrava-se a uma distância de mais de 40 quilômetros, transportada por veículos dos próprios colonos. Não havia escola; inicialmente foi montada uma de maneira improvisada, de "pau-e-pique", até construírem a definitiva, mais estruturada, que recebeu o nome de "Escola da Paz", construída com os esforços dos próprios colonos (foto 28). Essa unidade escolar atendia, em 2003, os filhos dos colonos - e também os filhos de piauienses que trabalhavam nos projetos agrícolas dos sulistas ou os que moravam nos povoados próximos - até a oitava série do ensino fundamental. Em 2004, foram implantadas, nessa escola, as séries do ensino médio, tentativa de assegurar a permanência dos jovens no povoado.

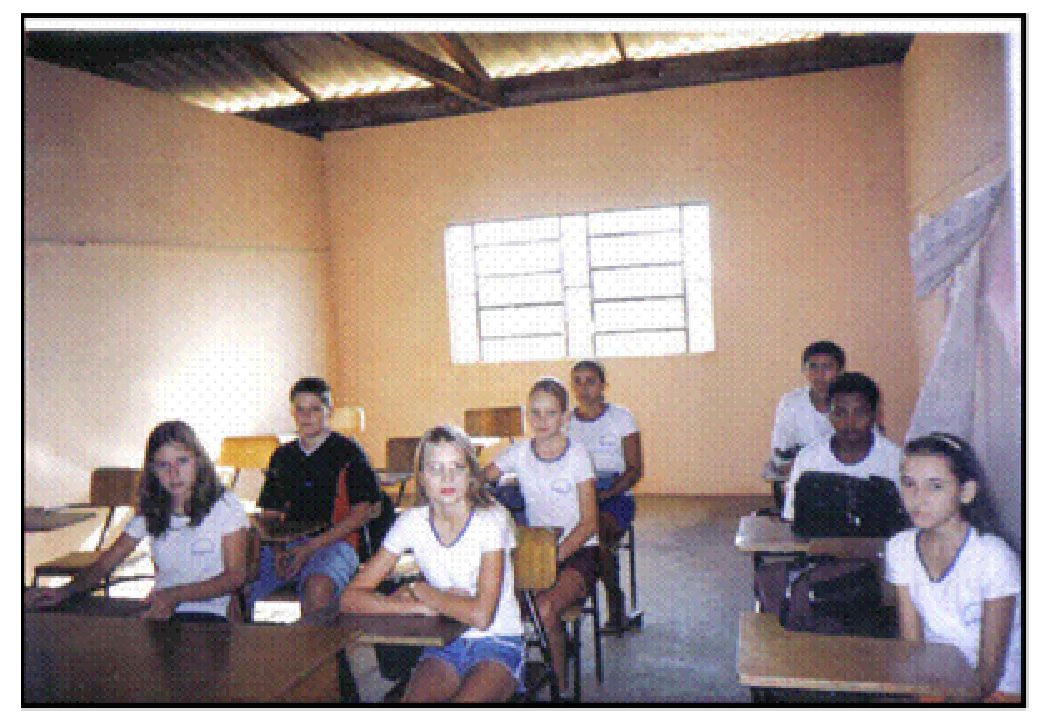

Foto 28 - Alunos da unioa escola instalada na agrovila Nova Santa Rosa. Observa-se a presença de piauienses e filhos de colonos sulistas. Foto do autor, setembro de 2006. 
A adaptação do grupo foi dificultada ainda pelos problemas de saúde que muitos se depararam diante de um ambiente natural novo e apresentando outras características naturais: intoxicação intestinal ocasionada pela mudança de ambientes e da água represada; ferimentos provocados por mordidas de insetos ou pelos pequenos acidentes ocorridos durantes os desmatamentos; problemas de pele produzidos pelo sol intenso e pelos ventos constantes em determinadas épocas do ano, numa população predominantemente de tez clara. Enfim, para tornar aquele um lugar em condições de habitação e em condições de sua incorporação à produção capitalista, os colonos de Santa Rosa precisaram superar vários obstáculos.

Alguns dos depoimentos são reveladores desse momento:

"Nós chegamos de ônibus até Bom Jesus, pegamos o caminhão com a mudança aqui, aí quando chegamos na serra aí veio o primeiro obstáculo que era subir a serra. Aí até chegar aqui não tinha estrada, não tinha nada, não tinha estrada para nós achar o lote para botar as coisas, tivemos que pegar um trator pequeno para limpar o ponto. Nós trouxemos nossa barraquinha junto, pronta com a armação de ferro para nós se instalar. A pior parte foi a falta d'água e a grande distância da cidade mais próxima."

(Bernadete Renger, moradora em Nova Santa Rosa. Entrevista concedida em setembro de 2003).

"Nós temos uma filha que dia 25 de março [de 1998] ela fazia 15 anos, que nós chegamos aqui dia 15, dez dias depois ela fez 15 anos. Aí para fazer o bolo, porque nós trouxemos galinha lá do Sul, umas 60 galinhas, mas elas não botava, porque elas entraram em estresse por causa da viagem, aí eu me lembrei que tinha um cara que ia descer para Bom Jesus, eu, então, pedi para ele trazer ovo e a vela de 15 anos, e assim foi indo, para conseguir fazer alguma coisa. Essa menina foi a que mais sentiu, porque menina moça na verdade veio muito pouco para cá. Rapaz na época tinha 22, nós tinha contado, mas moça mesmo tinha só ela e mais tarde que veio outras nessa idade."

(Anildo Schroder, morador em Nova Santa Rosa. Entrevista concedida em setembro de 2003).

"Quando chegamos aqui essa rua havia recém aberta, mas o mato havia crescido. Viemos com toda a mudança em cima de um caminhão, ficamos aqui debaixo de lona durante quatro meses, aí fizemos essa casa. Nunca tinha trabalhado de pedreiro (...). Água a gente ia buscar a 40 quilômetros. O projeto não saiu como tínhamos imaginado, porque os financiamentos não foram 
liberados no primeiro ano. Nós viemos em março e já logo a gente tinha se programado pra plantar (...) Chegar, abrir as áreas e plantar. Mas, não foi assim, o banco liberou o dinheiro já era muito tarde, sorte é que a Cooperativa ajudou um pouquinho. Isso foi mais difícil para a gente se animar, mas no segundo ano já começamos a se estruturar, mas não foi fácil (...). A gente tem três meninas agora, temos a mais velha já tá com 15 anos e, a mais nova, tá com 6 anos, então foi muito difícil."

(Laurindo Allebrando, morador em Nova Santa Rosa. Entrevista concedida em setembro de 2003).

"A gente chegou aqui dentro dessa gleba sabendo que aqui seria nossa cidade. Chegamos dia 22 [de fevereiro de 1998] à noite, eu cheguei, o Marcelo e o Tarcísio chegaram no dia 23 de manhã. A partir daquilo é que fomos abrir as ruas. Veio o agrimessor abrir as ruas, nós ficamos durante quatro a cinco meses puxando água da Vista Verde, da fazenda Agrobom. Eu puxei com minha caminhonete 45 pipas de água por dia, aí quem tinha uma bombona de 200 litros de água a gente enchia ela (...). A gente era parceiro desde o início até hoje (...). Havia uma necessidade entre nós, assim como há hoje, apesar de que hoje há um pouco mais de individualismo."

(Valdemar Kretschmer, morador em Nova Santa Rosa. Entrevista concedida em setembro de 2003).

A Nova Santa Rosa piauiense surge do trabalho coletivo dos colonos, que, diante da impossibilidade de continuar em seu espaço de origem por conta do cerco do capital sobre seus espaços de vida, decidem apostar a sorte em outro lugar. Uma trajetória que nem sempre todos conseguem suportar, muitos deles, dessa maneira, abandonam o projeto de vida traçado. Os que persistem se deparam com uma situação que exige inicialmente de todos uma ajuda mútua, pois a expectativa de obter o apoio das instituições não se realiza em sua totalidade, ou nunca se realiza conforme o prometido. Foi o que aconteceu na relação do grupo de colonos com a Cotrirosa.

O último depoimento exposto acima levanta uma questão importante presente no universo de construção de Nova Santa Rosa, verificado também em lugares onde acontece inicialmente um movimento de ocupação de migrantes empobrecidos e que despejam a esperança de uma vida melhor instalando-se em outra região, qual seja, o sentimento de solidariedade. Esse nasce das pessoas que participam do processo e ocorre em função da 
necessidade ou da dependência que se estabelece de um com os outros, pois todos se encontram numa mesma condição. Com o passar do tempo, no entanto, esses valores vão se perdendo, na medida em que a ajuda do outro deixa de ser tão premente. A partir daí transparece uma postura mais individualista e uma diferenciação de classe mais acentuada no interior do grupo.

As famílias de Nova Santa Rosa passaram por essa experiência. Os depoimentos obtidos dos colonos apontam que, no período imediatamente posterior à chegada dos primeiros indivíduos, houve uma aproximação do grupo por vários motivos: as dificuldades de lidar com um ambiente natural novo e hostil a que as pessoas não estavam acostumadas; as incertezas que surgiam diante de uma nova vida e o isolamento em relação a outros grupos sociais. Aparece nesse momento, então, um movimento de apoio ao outro, apesar de que já havia desde o início pessoas no grupo em condições econômicas distintas, medidas, por exemplo, pela quantidade de lotes adquiridos, algumas famílias apenas com um mínimo de 125 hectares, outras com vários. Num momento posterior, entretanto, quando começam a se estruturar economicamente, esse comportamento de coletividade vai cedendo lugar para o de individualidade, cada um buscando solucionar os seus próprios problemas.

A saída da Cotrirosa do projeto de colonização nos cerrados piauienses se insere nessa trajetória. A cooperativa que foi responsável pelo convencimento das famílias a aderir a um outro projeto de vida a ser executado a milhares de quilômetros de distância de sua região de origem - induzindo-as na idéia de praticar o cooperativismo em outro lugar - abandona-os logo após os primeiros anos de sua instalação no Piauí. Os colonos atribuem à Cotrirosa o princípio da divisão entre os então cooperados. Muitos deles denunciam a postura de alguns dirigentes da cooperativa, os quais, segundo alegam, tentavam administrar os recursos em benefício próprio ou que havia privilégios para determinados cooperados em detrimento de outros. Tal atitude provocou, na visão das famílias de Nova Santa Rosa, um descrédito nesse tipo de associação coletiva de classes, o que contribuiu também para espalhar a desconfiança entre os membros do grupo. 
“(...) No dia em que a Cooperativa foi vendida pra Bunge eu chorei, me manifestei e achei que foi uma lástima, porque se nós agricultores não podemos somar força, imagina individualmente, nós estamos mortos. Porque agora nós vamos chegar lá e negociar com eles um por um. Então, hoje nós vamos para o abatedor um por um. Então, como nós viemos com a cooperativa, eu acho uma infelicidade de nós ter vendido. Nós fomos vendidos, de tal forma que a gente ficou de uma maneira assim descrente (...). Eu disse para o meu filho: o dia em que você quiser se associar a uma cooperativa, eu como pai vou segurar tua mão pra você não entrar, porque muitas vezes as pessoas que são dirigentes usam desse expediente para manipular e fazer as coisas e acabam largando o navio a deriva, antes de chegar ao destino. Acho que não havia motivo para ter vendido, porque nós estávamos no lugar certo. Hoje o cooperativismo se perdeu, ninguém fala em cooperativa aqui, nós fomos traídos. Nunca mais eu vou entrar em cooperativismo, foi bom enquanto houve um interesse de certas pessoas, mas quando acharam que não éramos mais úteis nos deram um ponta pé".

(Valdemar Kretschmer. Entrevista concedida em setembro de 2003).

Entre os anos de 2001 e 2002, agravou-se a situação econômica da cooperativa e dos cooperados - embora tivessem uma boa colheita no ano de 2002, o que permitiu recuperar os ânimos. Os colonos foram abalados pelas safras ruins nos anos anteriores em razão das condições climáticas desfavoráveis e pelo acúmulo das dívidas decorrentes de empréstimos bancários e na cooperativa (aqueles que conseguiram), do pagamento da terra que foi adquirida em prestações, da aquisição de maquinários etc. $O$ fato é que em 2002 se desfez o projeto de construir um espaço de produção e de morada nos cerrados piauienses conduzido pela Cotrirosa. Naquele ano, as instalações da cooperativa foram transferidas para a Bunge Alimentos, que passou, a partir de então, a estabelecer novas regras com as famílias dos colonos; agora elas seguiriam atreladas aos ditames de uma grande empresa globalizada.

"(..)] Porque a Cotrirosa veio aqui com uma filosofia interessante, o cooperativismo é sempre interessante. Lá, no Sul, todas as cidades, numa região, têm cooperativa. É um sistema de produção que sem ele não teria como pequenos produtores, num imóvel de 25 hectares, se manter com estrutura. (...) É uma forma de defender, vamos dizer assim, os interesses num todo. A cooperativa veio pra cá em 1998 e se instalou com esse pessoal. Ela financiou uma estrutura de armazenagem que existe aqui hoje. Só que nesse meio caminho a gente teve algumas dificuldades climáticas e, de certa forma, 
econômicas, porque o pessoal que veio direto do Rio Grande do Sul é um pessoal que em termos de recurso é um pouquinho mais de dificuldade do que o pessoal que já vêm do Mato Grosso, Paraná, que já se instalou, que já tem um capital maior. Então, esse pessoal do Rio Grande do Sul tem uma dificuldade maior. (...) Só que nesse meio do caminho a gente teve algumas dificuldades, no primeiro ano a safra nunca é muito grande, a tecnologia não foi também muito elevada, a gente fez o que pôde. O segundo ano o clima também não foi tão bom, o dinheiro era curto, foi pouca soja. (...) Houve dificuldade de conseguir insumos, o calcário era uma coisa difícil. (...) o terceiro ano, 2001/2002, foi um ano que teve uma série de veranico que comprometeu muito, foi o ano que a gente entrou com a soja que é uma cultura que sofre menos, mas que também não fez milagre. (...) $O$ arroz ali foi praticamente perda total, soja ainda deu alguma coisinha. Então, todo mundo ficou meio mau das pernas, inclusive a cooperativa que até então havia investido no projeto, mas nunca investiu tanto, naquele ano não investiu no custeio do pessoal. 0 banco já não quis investir, porque o pessoal não conseguiu saldar o débito, num valor substancial. (...) Essa unidade era financiada pelo BNDES, como ela tinha que reembolsar o BNDES, surgiu, então, a Bunge que já estava interessada nessa unidade. A Bunge acabou, então, exatamente no dia 21 de junho de 2002, adquirindo essa unidade. Eu não me esqueço dessa data porque foi uma surpresa para todo mundo, ninguém esperava essa coisa de chegar a ter que vender a nossa cooperativa"

(Cleimor Gerloff, morador em Nova Santa Rosa. Entrevista concedida em setembro de 2003).

Do grupo que migrou para Nova Santa Rosa, os seus integrantes pouco se conheciam, pois saíram não somente de Santa Rosa, um município de médio porte com 65.016 habitantes (segundo Censo do IBGE, 2000), mas de vários municípios circunvizinhos. Os que se conheciam é porque são familiares ou amigos, mas não é o predominante entre os participantes dessa empreitada.

“(..) Tem gente que eu não conhecia, conheci aqui, porque de Santo Cristo veio muita gente. Era tudo gente meio estranha, mas aqui parece ser tudo gente da mesma família. Tem uma pessoa que veio da cidade de Santo Cristo que quando éramos pequenas brincávamos juntas, perdemos o contato e depois nós se encontremos aqui de novo. Eu vim antes, ela veio morar pra cá e nós se encontremos aqui, de anos. Estudamos juntas de pequena, perdemos $o$ contato e se encontremos aqui".

(Bernadete Renger. Entrevista concedida em setembro de 2003). 
A chegada em Nova Santa Rosa representava, nesse sentido, construir novas relações entre as pessoas e definir novas funções numa área em processo de formação, que deveria ser gerida tendo como parâmetro as condições definidas pelo ritmo da agricultura produtivista. Nesse caso, o que se vê em Nova Santa Rosa é uma diferenciação nas atribuições das funções entre os homens e as mulheres. Os primeiros encarregam-se, predominantemente, de gerenciar a propriedade e a produção, trabalham às vezes toda a noite, dormem uma parte do dia, na outra preocupam-se em reparar os maquinários agrícolas, ou vice-versa. Não há tempo para participação em outras atividades relativas à organização de um espaço coletivo recém-fundado, esse papel comumente cabe às mulheres.

“(...) Aqui é meio difícil reunir os homens, por causa da lavoura. Sempre eles estão à noite na lavoura. Na parte da manhã, sempre aos domingos eles se dedicam aos cultos e depois já vão para a lavoura".

(Lurdilene da Silva, mineira, pastora da igreja luterana. Entrevista concedida em setembro de 2003).

Além de cuidar dos afazeres domésticos e, algumas, até de acompanhar o marido na condução da lavoura, as mulheres são responsáveis por administrar ou atender as demandas da coletividade. Desde o início da chegada das primeiras famílias em Nova Santa Rosa, a saúde ficou, por exemplo, sob responsabilidade de uma agente de saúde pertencente ao grupo, que se encarrega de atender toda a população local. A escola da agrovila também é toda ela conduzida por mulheres, as quais além de lecionarem, administram a burocracia. Nesses locais quase não se vê a presença masculina.

"As mulheres exerce mais um trabalho da comunidade, é um trabalho que consegue acrescentar, e também do lar, que nem eu, peguei o trabalho de agente de saúde, mas tem o trabalho das crianças, tudo isso. A gente tem que cuidar dessa parte também, mas também da horta, do pomar (...), mas trabalhando com a comunidade a maioria são as mulheres".

(Bernadete Renger. Entrevista concedida em setembro de 2003). 
Em Nova Santa Rosa as mulheres são as que mais se ressentem do impacto nesse processo brusco de mudança de região. Abdicaram da convivência com o restante da família lá no Sul para acompanhar seus esposos num universo de incertezas e cheio de angústias. No recém-formado núcleo urbano é preciso suportar os novos e difíceis desafios que se apresentam diante de um outro ambiente. Além disso, convivem permanentemente com a ausência temporária dos seus maridos, os quais passam a maior parte do tempo cuidando da lavoura, às vezes - quando as propriedades estão muito distantes da agrovila - permanecem fora, na unidade de produção, durante toda a semana, retornando somente aos fins de semana. Tudo isso cria uma situação difícil de lidar, o que leva a mulher, em muitos casos, a ter que conviver com o problema da depressão. As informações obtidas indicavam que uma parcela importante das moradoras em Nova Santa Rosa apresentava características desse mal.

O relato da agente de saúde da agrovila citando o seu próprio caso ilustra bem a dimensão do problema nessa comunidade:

"Há muitos casos de depressão aqui entre as mulheres. Eu também já tive. Eu acho que foi por causa da mudança, é mudança demais. O conforto da vida que a gente deixou lá, o lazer e o conforto que a gente cortou muito. Aqui a gente não tem onde ir muito, a cidade é longe, aqui em cima é tudo muito difícil. (...) Então, eu tive uma depressão bem feia, e foi difícil sair, por causa do lugar, porque minha família ficou toda lá no Sul, só veio meu marido e minha filha, o resto ficou tudo lá."

(Bernadete Renger. Entrevista concedida em setembro de 2003).

A superação das dificuldades do cotidiano é feita pelo coletivo das próprias mulheres, as quais proporcionam freqüentes atividades à procura de consolarem umas às outras (foto 29).

"Têm umas que têm dias que estão pra baixo, tem dias que choram muito, daí a gente anima elas. Aqui a gente se ajuda muito, todo mundo sabe que precisamos um do outro. Quando alguém tem algum problema todo mundo vai lá e se ajuda."

(Bernadete Renger. Entrevista concedida em setembro de 2003). 


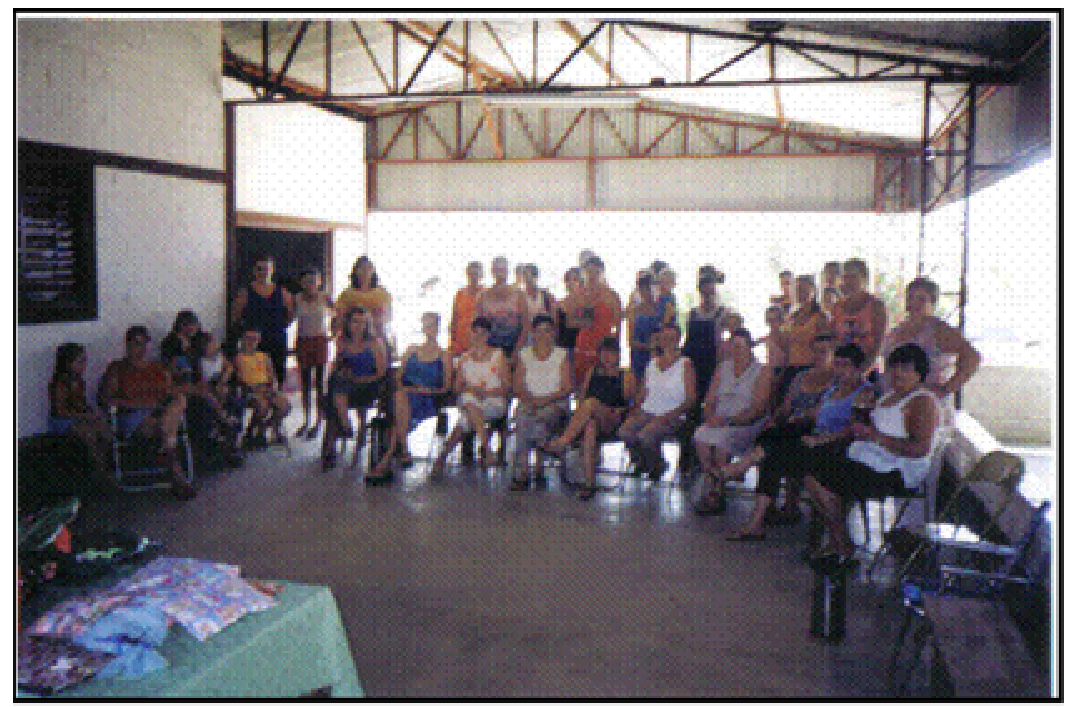

Foto 29 - Reuniăo de mulheres moradoras em Nova Santa Rosa. Os encontros femininos săo frequentes e visam amenizar a solidâ de um espaço em construçẩo. Foto do autor, setembro de 2003.

Nesse caso também as pessoas procuram refúgio na religião, buscando conforto espiritual para suportar esses momentos difíceis. Em Nova Santa Rosa, há participação de duas religiões importantes que dividem o cotidiano da população, a luterana (seguida pela maioria das pessoas da agrovila, descendentes de alemães) e a católica (seguidas, predominantemente, pelos descendentes de italianos). Ambas realizam seus cultos improvisados nas casas dos colonos ou na escola, pois ainda não há os templos, cada um com seu espaço de manifestação religiosa.

"Olha a gente participa da igreja católica, porque aqui têm duas igrejas, só que por enquanto, não tem o prédio, então o pessoal praticamente ocupa, a gente cedeu o restaurante para fazer as rezas, no domingo de manhã. A igreja luterana já tem um outro lugar, o local dela é lá na escola”.

(Adilson Jacob. Entrevista concedida em setembro de 2003). 
A aglomeração urbana de Nova Santa Rosa e outras que surgem no sul do Piauí fazem parte agora de uma organização espacial comandada pela lógica da agricultura capitalista moderna. O que se verifica nesse momento nos cerrados piauienses, no que diz respeito a uma urbanização que emerge a partir da presença de novos agentes econômicos, também ocorreu em outras localidades de fronteira agrícola. Ou seja, são cidades que surgem repentinamente a partir da instalação de um grupo transladado do Sul do Brasil e que em poucas décadas se situam como áreas urbanas importantes, aceleradas pelo ritmo do capital. Elas nascem suprimindo fases, na medida em que surgem e imediatamente já incorporam o tempo do mercado. Nos dizeres de Santos (1993: 52), "não nascem rurais, já surgem urbanas".

São concebidas, portanto, não pelo encontro de pessoas que, por razões econômicas, confluíam para um determinado lugar e ali iniciavam um projeto de convivência coletiva, mas com incorporação, nesse espaço em construção, das outras dimensões da vida. O novo urbano prescinde dessas manifestações. Em Nova Santa Rosa, os encontros sociais são reduzidos, acontecendo predominantemente aos fins de semana em razão de seus moradores se preocuparem dioturnamente em atender às crescentes demandas do mercado consumidor agrícola. O tempo da vida, nesse sentido, é substituido pelo tempo da produção e do consumo das coisas, sem que haja a possibilidade da convivência das pessoas. Naquele povoado, antes de se construir uma igreja - símbolo da formação de um núcleo urbano no passado, que além da promoção religiosa também cumpria o papel de reunir as pessoas - é construído um posto de combustível; há menos circulação de pessoas pelas ruas do novo povoado do que de caminhões. Isso demonstra que Nova Santa Rosa já nasce com a incorporação de um outro sentido de consumo do urbano, na medida em que perde sua qualidade de locus da convivência humana.

$\mathrm{Na}$ formação das novas cidades do período contemporâneo, sob a determinação da circulação acelerada da mercadoria, dispensa-se o papel que o tempo natural exerce na condução dos processos sociais. Manifestações que ainda se observam em algumas das pequenas cidades do Brasil agrário. Ao 
estudar o universo pioneiro de gaúchos na cidade de Chapadão do Sul, em Mato Grosso do Sul, Martins (1993: 158) concebe as cidades surgidas na esteira do agronegócio como aquelas que se instalam abortando etapas ou, como coloca o referido autor, cidades que nascem, mas não vivem plenamente os percursos do urbano de outros tempos. Para Martins, Chapadão do Sul pode ser considerada uma cidade "sem infância", pois:

"nasceu adulta porque foi concebida segundo uma racionalidade que passa longe da festa como sentido de apropriação, de 'consumo' da cidade pelas representações da imediaticidade da vida. As 'festas a bem da colonização' precederam a cidade. Como não-festa, elas são privadas de espontaneidade, pois providas, em essência, de uma intencionalidade dada de antemão, que tem a cidade como finalidade de ser o local e o centro do consumo das coisas, do encontro delas, e não das pessoas. Estas vivem em constantes desencontros (...)".

Rosselvelt Santos (1998) identificou, do mesmo modo, uma nova lógica de organização das cidades dos cerrados mineiros após a chegada agricultura capitalista moderna. Nesse caso, as cidades que ganharam centralidade nesse processo romperam com os seus antigos estilos de produção do urbano. $O$ advento da soja na região significou a presença de novos ritmos determinados para a reprodução do capital.

A futura cidade de Nova Santa Rosa participa dessa lógica, chega aos cerrados piauienses junto com outras formas de imposição, tanto na organização do espaço e do tempo quanto na vida das pessoas. É um espaço que se constitui pelo esforço de pequenos agricultores anônimos mobilizados pelo capital. O tempo de produção da vida segue os desígnios do ritmo do capital, que dispensa as demais experiências vividas em outro momento, não se admite, nesse sentido, a lentidão dos processos sociais marcados pelo tempo da natureza.

O espaço urbano de Nova Santa Rosa repete também as manifestações de outras cidades da fronteira, que se pautam, muitas delas, pela seletividade social. Ali não se admite outros moradores a não ser os que podem adquirir terrenos com preços elevados, o que inviabiliza a fixação de trabalhadores braçais necessários às lavouras dos moradores da agrovila, principalmente os piauienses. Esses comumente moram em galpões cedidos pelos produtores 
agrícolas ou improvisam barracos de lona nos terrenos baldios, em que se admite instalarem-se somente temporariamente enquanto durar o trabalho. Da mesma forma, não se admite os perdedores, freqüentemente os sulistas que não conseguiram vencer as dificuldades financeiras e do meio ou acompanhar a produção do tempo do capital, ditada pelo jogo da produção das mercadorias. Os que não se ajustam ao tempo único do capital são conduzidos à exclusão não somente dos meios de produção, mas também dos espaços de morar. Isso vale tanto para os sulistas que fracassam nessa transferência dolorosa de seus espaços de vida anteriores quanto para os piauienses pobres que cada vez mais são expulsos de seus espaços de produção e também de moradia por conta do avanço do capital. 


\section{6 - A PRESENÇA DA BUNGE ALIMENTOS E DE OUTRAS EMPRESAS DO AGRONEGÓCIO NO SUL DO PIAUÍ}

O crescimento da produção de grãos nos cerrados piauienses despertou o interesse de empresas para aquela área. Num primeiro momento elas vão se dedicar à compra de terras para lançar a tal mercadoria no mercado imobiliário. É o caso, por exemplo, da antiga Varig Agropecuária e do Grupo Cacique, ambas detentoras de grandes extensões de terras no sul do Piauí desde a década de 1980. Posteriormente, desembarcam outros segmentos de empresas, sobretudo de insumos agrícolas e revendedores de maquinários: John Deere, Valtra, New Holland etc. A Bunge Alimentos, entretanto, foi a mais importante empresa instalada nos cerrados piauienses. A sua chegada foi marcada por uma agitação geral tanto entre os produtores agrícolas modernizados e comerciantes quanto nos setores governamentais. Estes últimos disponibilizaram todos os suportes (incentivos fiscais, investimentos em infra-estrutura etc.) para que a empresa se interessasse pelo Piauí. A sensação mantida por todos era a de que a presença da empresa nos cerrados constituiria uma alavanca definitiva para a inserção do sul do estado no patamar de modernização retardatária de outras regiões de fronteira mais consolidadas do país. A Bunge impõe, a partir de então, uma nova configuração nas relações de produção e de comercialização de grãos dos cerrados piauienses, tornando-se a principal empresa vencedora da concorrência local.

Antes, porém, de analisar a presença dessa empresa e de suas formas de atuação nos cerrados piauienses será necessário ampliar um pouco mais a discussão a respeito das características atuais das empresas vencedoras no setor agro-alimentar e de que maneira elas utilizam os mecanismos da globalização para a formação de grandes conglomerados econômicos no mundo de hoje. Pretende-se, também, sucintamente, compreender alguns dos caminhos percorridos pela Bunge Alimentos que levaram a empresa a se transformar em um dos mais importantes grupos do complexo agro-alimentar. Esse percurso, mesmo que resumido, habilitar-nos-á a melhor entender os mecanismos pelos quais a empresa impõe formas de subordinação aos agricultores produtores de grãos no sul do Piauí. 
No mundo contemporâneo, as grandes empresas assumem cada vez mais o papel de concentradoras de capital, eliminando as demais por um processo feroz de concorrência. $O$ poder econômico que elas possuem revertem em comando sobre os territórios nacionais para os quais definem ações visando estabelecer formas de apropriação das riquezas (dos territórios). Suas estratégias de acumulação se fortaleceram diante da progressiva internacionalização da produção, possibilitando atuar em diferentes países com custos reduzidos por conta da exploração da força de trabalho e de matériaprima locais e do uso de tecnologia avançada no processo de produção e administração. Diante desses novos processos de produção de riqueza, o terceiro mundo, diferentemente de outros momentos, reduz a participação nos investimentos das grandes empresas direcionados diretamente à produção, principalmente porque a parcela de ganho com a exploração da força de trabalho (mais barata ali) que elas obtinham antes hoje é cada vez menor. Além disso, tais empresas ampliam seus tentáculos sobre o mercado financeiro, controlando também nesse setor parte importante da movimentação de capital. Desse modo, a grande empresa trabalha de maneira interligada através de produção de mercadorias, a partir de sistemas de engenharia industrial sofisticados poupadores de trabalho vivo, e através da movimentação de capital fictício, dando a ela, em cada um desses níveis, lucros extraordinários e poderes de comando nas decisões político-econômicas, tanto na esfera mundial quanto no âmbito dos Estados nacionais. A maneira pela qual a grande empresa reproduz seu capital, realizando a junção de suas operações entre o industrial e o financeiro, é apontada por Chesnais (1996: 275):

"No tocante ao grupo industrial, já deve ser banida a idéia de que haveria uma separação estanque entre as operações direta ou indiretamente ligadas à valorização do capital na produção, de um lado, e de outro lado as operações dirigidas à obtenção de lucros de tipo puramente financeiro. No entanto, permanece a distinção essencial, que separa o capital produtivo, engajado num movimento de valorização do capital onde é central a maximização da produtividade do trabalho, e o capital dinheiro, remunerado pelos juros, aos quais se somam atualmente todo tipo de lucros financeiros ligados ao movimento 'autônomo' do capital monetário". 
No segmento agro-alimentar, assim como nos demais setores da economia, também ocorre grande concentração. Poucas empresas controlam a produção e a distribuição de toda a cadeia de produção e comercialização de alimentos. Em 1990, calculava-se que somente as cem maiores empresas de alimentos detinham cerca de um terço das vendas totais de alimentos processados no mundo (Rama, 1994, apud Martinelli Jr., 1999). Tal fato demonstra que as estruturas voltadas para a destruição da concorrência que essas empresas mantêm são cada vez mais fortalecidas, inviabilizando praticamente a presença de pequenas e médias empresas nesse setor, muitas delas adquiridas pelas vencedoras. Diante desse movimento concentrador, a competição se restringe a apenas alguns poucos grupos econômicos. A grande capacidade de gerenciamento mantida por essas empresas permitindo sua descentralização pelo mundo, aliada à eficiência em realizar suas estratégias de atuação nos territórios constituem os pilares da consolidação de tais grupos. A tabela 09 contendo a relação das 15 maiores empresas que atuam no Brasil no setor de agronegócio demonstra os altos faturamentos financeiros, confirmando que o controle monetário se reverte também em domínio das estruturas de beneficiamento e distribuição dos produtos agro-alimentares.

\begin{tabular}{|c|c|c|c|c|}
\hline \multicolumn{5}{|c|}{ Tabela 09 - As 15 maiores empresas do agronegócio instaladas no Brasil } \\
\hline $\begin{array}{l}\text { Ordem por } \\
\text { faturamento } \\
\text { em } 2005\end{array}$ & Empresa & Segmento & $\begin{array}{c}\text { Faturamento } \\
\text { Bruto em } 2005 \\
\text { (em R } \$ \\
\text { milhões) }\end{array}$ & $\begin{array}{c}\text { Origem do } \\
\text { capital }\end{array}$ \\
\hline 01 & Ambev & bebidas & $28.878,7$ & Bélgica \\
\hline 02 & Carrefour & Supermercados & $16.200,0$ & França \\
\hline 03 & Grupo Pão de Açúcar & Supermercados & $16.121,0$ & Brasil/França \\
\hline 04 & Wal-Mart Brasil & Supermercados & $11.731,8$ & Estados Unidos \\
\hline 05 & Cargill Agrícola & Ind.soja e óleos & $11.517,5$ & Estados Unidos \\
\hline 06 & Bunge Alimentos & Ind.soja e óleos & $10.846,8$ & Bermudas \\
\hline 07 & Sadia & $\begin{array}{l}\text { Frigorif. e Prod. } \\
\text { animal }\end{array}$ & $8.328,0$ & Brasil \\
\hline 08 & Souza Cruz & Produtos do fumo & $7.819,3$ & Grã-Bretanha \\
\hline 09 & Nestlé & Lacticínios & $6.672,0$ & Suíça \\
\hline 10 & Perdigão Agroindustrial & $\begin{array}{c}\text { Frigorif. e Produção } \\
\text { animal }\end{array}$ & $5.873,3$ & Brasil \\
\hline 11 & Dow Brasil & $\begin{array}{l}\text { Inseticidas e } \\
\text { defensivos }\end{array}$ & $5.146,7$ & Estados Unidos \\
\hline 12 & Bunge Fertilizantes & Fertilizante & $5.018,6$ & Bermudas \\
\hline 13 & ADM do Brasil & Ind.soja e óleos & $4.877,9$ & Estados Unidos \\
\hline 14 & Copersucar & Açúcar e álcool & $4.500,0$ & Brasil \\
\hline 15 & Makro & Atacado e varejo & $3.895,1$ & Holanda \\
\hline
\end{tabular}

Fonte: Anuário Exame, 2006 
Um outro fator que permitiu a expansão rápida das grandes empresas do segmento de alimentos diz respeito às mudanças ocorridas nos paradigmas de consumo alimentar da sociedade contemporânea incorporando, crescentemente, alimentos processados pela indústria e produzidos em larga escala, além de haver uma cada vez mais homogeneização dos hábitos alimentares da população mundial. Isso redunda no papel protagonista que as grandes empresas exercem atualmente, pois estão mais habilitadas a atender prontamente os novos costumes alimentares, muitos dos quais induzidos por elas próprias. Possuem, nesse sentido, estruturas suficientemente capazes de colocar em diferentes mercados os produtos que a sociedade global passa a consumir. A padronização dos gostos representou, assim, um passo importante para ampliar a presença das grandes empresas em escala mundial. A esse respeito diz Ortiz (1994: 80/87):

"Os alimentos descolam de suas territorialidades para serem distribuídos em escala mundial. Não existe nenhuma 'centralidade' nas cervejas, chocolates, biscoitos, refrigerantes. Trata-se de produtos consumidos mundialmente e distribuídos por grupos multinacionais. (...) No mundo funcional da mercadoriamundo, os alimentos perdem a fixidez dos territórios e dos costumes. Eles se adequam às circunstâncias que os envolvem. Nesse contexto, a veracidade dos mapas alimentares se esvai, pois seus traços essenciais são informações ajustadas à polissemia dos contextos. Não há mais centralidade, a mobilidade das fronteiras dilui a oposição entre autóctone e o estrangeiro; (...) rompe-se, assim, a relação entre o lugar e o alimento; a cozinha industrial não possui nenhum vínculo territorial".

A padronização do consumo global permitiu, por um lado, um afunilamento dos grupos com poderes de atuação para além das fronteiras nacionais ampliando seus lucros com a produção e a comercialização de alimentos propriamente dito. Por outro lado, tais empresas passam a diversificar suas áreas de atuação para outros setores complementares e, às vezes, muito distintos de seu ramo de atuação. Algumas delas expandem seus negócios apostando numa diversificação ampla de suas economias com presença, por exemplo, no sistema bancário, na indústria siderúrgica, na têxtil, na química, na de construção civil etc. O mais freqüente, entretanto, nas estratégias desses grupos é a atuação de maneira vertical e integrada, 
estabelecendo controle dos setores a montante e a jusante da indústria alimentícia. Essa situação se aplica àqueles grupos que ao mesmo tempo comercializam e processam grãos, industrializam e distribuem o produto final, mas também passam a ser importantes fornecedores de insumos e de outros ingredientes para os agricultores e para as empresas produtoras de alimentos finais.

Essas empresas que vencem a concorrência traçam também planos para as suas ações visando ampliar o poder de liderança nos distintos países, utilizam para isso suas poderosas estruturas econômicas. Para Martinelli Jr. (1999: 130) a internacionalização das poderosas empresas ocorre obedecendo esquematicamente quatro tipos básicos de estratégias, assim formulados por Tarandeau (1993): a doméstica centralizada, a industrial regional ou multidoméstica, a industrial global coordenada e a industrial regional e global combinada e coordenada. Este último tipo de empresa é o que mais se aproxima das estratégias adotadas pelas grandes empresas de alimentos,

“(...) caracteriza-se pela descentralização geográfica, mas diferentemente, as plantas de montagem são localizadas próximas ao mercado consumidor; neste tipo, a concepção de base dos produtos é centralizada no país de origem, mas as adaptações necessárias aos diferentes mercados são realizadas pelas plantas locais".

\section{Continua o autor:}

"No caso da internacionalização recente das empresas de alimentos (...), as evidências parecem apontar para a maior importância das estratégias regionais e globais levadas a cabo pelas grandes empresas. Nesse processo, porém, devem ser considerados ainda elementos que relativizam a possibilidade do deslocamento geográfico das plantas em função dos fatores locacionais da matéria-prima - principalmente das atividades processadoras primárias - e da amplitude de consumo possível, em cada mercado, devido a maior heterogeneidade existente nos diversos padrões de consumo".

A Bunge Alimentos se adequa aos contextos expostos acima. Essa grande empresa, que está entre as quinhentas maiores empresas do mundo (Oliveira, 2005), forma-se originalmente atuando no comércio de grãos, mas ao longo dos anos diversifica suas atividades para os setores têxtil, de papel, químico e de insumos agrícolas. Nos anos 1980, o então grupo Bunge y Born 
já possuía mais de 40 empresas no Brasil, portando diversos nomes e áreas de atuação (Brum, 1983). Nos anos $1990^{89}$, a empresa concentra sua atuação no cenário mundial em três áreas do agronegócio, que se complementam: fertilizantes, grãos e oleaginosas e produtos alimentícios elaborados. No ano 2000, o grupo Bunge sofre reestruturação societária e no seu sistema de gerenciamento, o que culmina com uma maior centralização das operações administrativas, verticalizando o sistema de produção e comercialização de alimentos e fertilizantes. Forma-se daí um grande conglomerado de empresas, cujas divisões centram-se nos setores de fertilizantes com o controle da Manah, Serrana, lap e Ouro Verde (Bunge Fertilizantes) e da Ceval e Santista (Bunge Alimentos); além da divisão de logística dos portos sob o comando da Fertimport ${ }^{90}$.

O crescimento econômico do atual grupo Bunge que o levou a tornar-se uma empresa oligopolista do setor agro-alimentar, entretanto, tem uma longa história no processo de concentração de capital. Suas operações iniciam na Holanda em 1818, quando foi fundada a Bunge \& Co., para comercializar grãos e produtos importados das colônias holandesas. Em 1859, apoiada pelo reino da Bélgica, transfere sua sede para a Antuérpia, onde se transforma no braço comercial da expansão internacional do novo Reino. Em 1884, um dos componentes da família Bunge muda-se para a Argentina, onde, com outros sócios cria a empresa coligada com o nome de Bunge y Born, a qual passa a participar do mercado de exportação de grãos do país. É um braço da Bunge y Born que se instala no Brasil a partir de 1905 obtendo parte do capital da empresa brasileira Moinho Santista Indústrias Gerais.

Esse foi o começo de uma rápida expansão no país, em que as aquisições se estenderam para diversos setores, incluindo o de alimentação, o de agronegócios, o de minero-químico, o de têxteis etc. Nos anos 1990, a empresa fez uma grande investida de capital conquistando empresas

\footnotetext{
${ }^{89}$ As informações que seguem foram obtidas junto ao centro de memória da Fundação Bunge (www.fundacaobunge.org.br).

$90 \mathrm{Em}$ alguns portos brasileiros a Bunge é a única controladora dos terminais de grãos ou de importação de fertilizantes. Isso ocorre, por exemplo, no porto de Santos - SP. A exploração de duas áreas de terminais importantes de tal porto passou a cargo da Bunge após um acordo financeiro (sob suspeita de irregularidades) firmado com a Ferronorte (que recebeu do Estado a concessão, sem licitação, dessas áreas públicas de $500 \mathrm{mil} \mathrm{m}^{2}$ ). Essa empresa ferroviária transferiu o controle de tais áreas à multinacional, garantindo a essa o domínio da importação de fertilizantes (In: Folha de S.Paulo, 25 de agosto de 2005).
} 
importantes brasileiras, como o grupo Ceval, um das mais importantes do ramo de processamento de soja e de frigoríficos; contam-se também a aquisição de diversos moinhos espalhados pelo Brasil, tais como: os moinhos Fluminense, Recife, Porto Alegre, Natal, Joinville, Ponta Grossa, Marilú, dentre outros. Essa mesma estratégia foi usada para o setor de fertilizantes, no qual se apropriou das principais empresas desse segmento produtivo, como as aqui mencionadas Manah, lap, e Ouro Verde. Essas se juntaram à Serrana S.A. para a formação da Bunge Fertilizantes. Tais empresas, além de comercializarem fertilizantes, oferecem serviços de agricultura de precisão e, em consórcio com a DuPont, formaram uma joint venture para a produção e distribuição em escala global de ingredientes funcionais e lecitinas; dessa parceria surgiu a empresa Solae. Recentemente, a Bunge passa a se interessar também pela produção e comercialização de biodiesel, segmento do mercado de combustíveis que promete constituir-se em um dos mais promissores nos próximos anos.

Essas investidas visando a concentrar capital, sobretudo nos anos 1990, levaram o Grupo Bunge a aumentar sua participação no cenário mundial e no brasileiro. Tornou-se a maior processadora mundial de oleaginosas e é a principal empresa brasileira nesse setor. Possui, ademais, a liderança na América Latina na industrialização de soja e trigo e na produção de fertilizantes. No Brasil, são mais de 300 instalações, entre fábricas, portos e centro de distribuição e silos de grãos, produzindo um faturamento, em 2004, de 23,2 bilhões de reais. A presença da empresa no território nacional segue uma estratégia de localização que cobre os mercados regionais de aquisição de matéria-prima e venda de produtos semi e/ou industrializados e, ao mesmo tempo, busca ampliar sua logística de escoamento para o mercado externo. No Piauí, atuará seguindo os passos de controle da compra de soja, subordinando os agricultores de tal produto, nessa e em outras esferas, e da venda de soja processada nos mercados regional e/ou internacional.

\section{1 - A instalação da Bunge Alimentos no Piauí}

A primeira fase de instalação da Bunge no Piauí definiu-se pela tentativa de controlar aqueles setores estratégicos da cadeia de distribuição de grãos, 
sobretudo na etapa de secagem e armazenamento do produto colhido. Nesse caso, a empresa adquiriu, a partir de 2002, todos os grandes silos dos cerrados piauienses estrategicamente localizados próximos aos principais produtores, em Uruçuí e Bom Jesus. Tais silos passaram apenas a armazenar soja, já que a sua unidade de produção instalada em Uruçuí destina-se ao esmagamento do produto para obter óleo e farelo. Nasce daí o enquadramento da maioria dos novos produtores locais à lógica da empresa, pois restam a eles poucas alternativas de comercializar seus produtos em outros mercados mais distantes, em função, sobretudo, do encarecimento do transporte. Além disso, a própria Bunge vende farelo no mercado nordestino, reduzindo assim, a autonomia dos produtores de comercializarem suas safras com outros grupos econômicos.

A expansão da Bunge no Piauí ocorreu rapidamente; em pouco tempo, comprou as unidades de armazenamento e instalou, em 2002, uma planta de fábrica em Uruçuí para beneficiamento de farelo e óleo de soja com capacidade de esmagamento de 6.000 toneladas do produto/dia; no ano de 2005 esmagava em média 2.500 toneladas/dia. Essa planta de fábrica em território piauiense é tida como a mais moderna da empresa, apresentando uma reduzida equipe administrativa e um alto nível de automação. Possui duas balanças rodoviárias eletrônicas, sistema de classificação de grãos por coleta pneumática, sistema de descarregamento por tombamento, imprimindo maior velocidade ao processo, além de um sistema de limpeza, secagem e armazenamento para 100.000 toneladas guardadas em dois grandes silos, de grãos e de farelo; ao passo que os tanques de óleo armazenam cerca de quatro milhões de litros do produto bruto (foto 30). O refino ocorre na unidade de Ipojuca, em Pernambuco, para onde é levado o óleo através de caminhões. Para se carregar um caminhão com farelo de soja gasta um tempo médio de 1,5 minuto e com óleo cerca de 20 minutos, tudo controlado por meios automáticos. Com apenas duas pessoas é possível atender a essas funções. No total, são aproximadamente 200 funcionários (entre fixos e terceirizados). 0 pessoal responsável pela parte operacional fica, comumente, a cargo dos piauienses, enquanto a de gerenciamento, que necessita de maior qualificação, vem de fora do estado. A planta conta ainda com um laboratório de análise e acompanhamento da qualidade da soja recolhida dos produtores. 


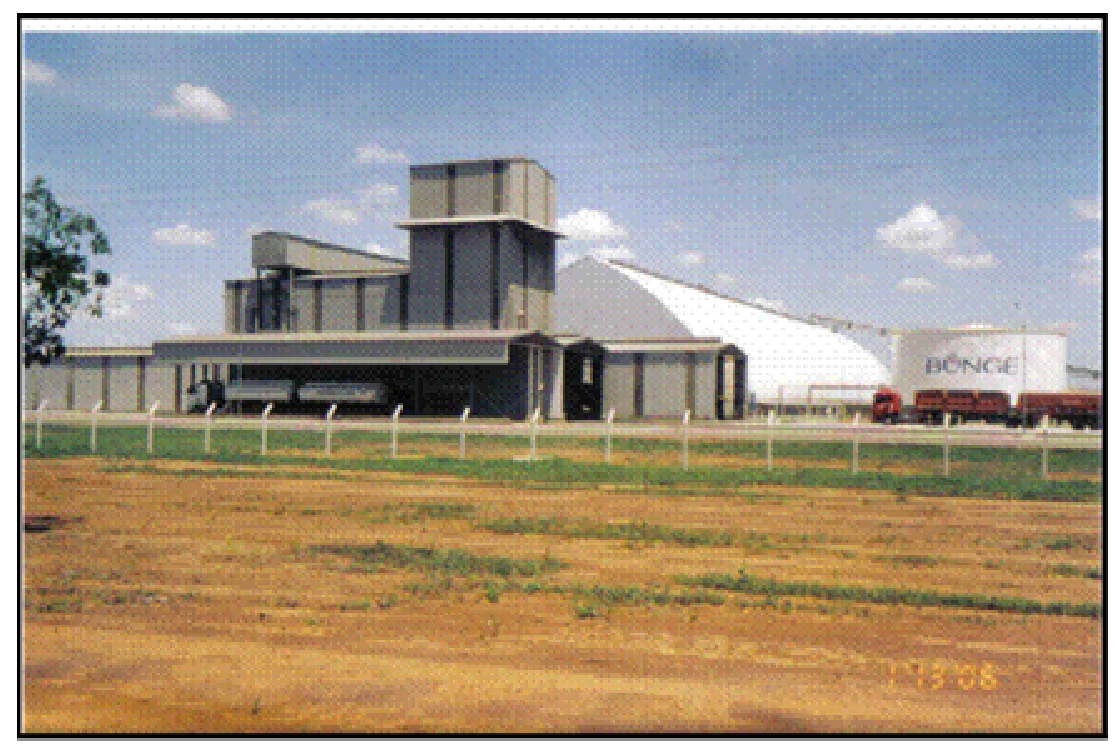

Foto 30 - Planta de fábrica da Bunge Alimentos em Uruçuí. Foto do autor, janeiro de 2006.

O movimento de caminhões é intenso, dia e noite, dentro e fora da fábrica. No período da safra costuma-se desembarcar, em média, 700 caminhões diários que descarregam até 8.000 toneladas/dia. Toda a frota é terceirizada, pertencente a autônomos e a empresas transportadoras. A soja utilizada pela planta de Uruçuí para a sua transformação em óleo e farelo é produzida predominante no Piauí, mas em determinadas épocas é enviada também dos estados do Maranhão e de Tocantins. No caso piauiense, da produção que se calcula atualmente para o estado, de aproximadamente 500 mil toneladas/ano, a Bunge é responsável pela compra de cerca de $400 \mathrm{mil}$ ton./ano. Parte da soja adquirida dos produtores do Maranhão e de Tocantins é encaminhada para a planta de Luis Eduardo Magalhães ou é exportada. Nesse último caso, escoa-se o produto daqueles estados através do Porto de Itaqui MA ou llhéus - BA, com predomínio para o primeiro. Nos dois portos, a empresa possui unidades receptoras de grãos. Em Itaqui, a unidade de armazenamento de 50.000 toneladas localiza-se dentro do porto e se utilizadas estruturas da Companhia Vale do Rio Doce (CVRD) para embarcar o produto. Antes de chegar a São Luís - MA, o escoamento da soja dos estados do Piauí e do Maranhão e, eventualmente, de Tocantins segue inicialmente para o município de Porto Franco - MA, onde há um outro silo da empresa com 
capacidade de 50.000 toneladas e da onde é feito o transbordo de carga que passa dos caminhões para os trens da CVRD.

Nos estados de Tocantins, Maranhão, Piauí e Pará, a Bunge possui ou arrenda cerca de 19 silos, os quais são os mais requisitados para abastecer a planta de fábrica de Uruçuí ${ }^{11}$ (mapa 14). Essas áreas produziram, em 2005, aproximadamente 2.300 .000 toneladas de soja sendo que 630.000 das quais podem permanecer nos silos da Bunge ${ }^{92}$, empresa que mais apresenta capacidade de armazenamento do produto nessa área. Tais unidades de armazenamento são construídas, freqüentemente, em lugares estratégicos, nas proximidades das fazendas produtoras de grãos, seguindo uma orientação da política adotada pela empresa, qual seja, a de manter uma maior "empatia" com os agricultores vendedores de grãos. No caso piauiense a capacidade de armazenamento da empresa é de 240 mil toneladas em seis silos, instalados em Uruçuí (03 silos), Currais (01 silo), Bom Jesus (01 silo) e Baixa Grande do Ribeiro (01 silo). No que diz respeito apenas à capacidade de armazenagem, a Bunge retém um pouco menos da metade de toda a produção obtida no estado. Tal situação praticamente obriga o produtor agrícola modernizado a comercializar suas safras com a empresa; isso acontece principalmente com aqueles de menor estrutura financeira que não possuem lugares adequados para guardar por mais tempo os seus produtos.

Por um lado, verifica-se a consolidação das amarras estabelecidas pela Bunge sobre os produtores agrícolas obrigando-os a comercializarem seus produtos com a empresa, pois ela se encarregou, com seu poder de vencer a concorrência, de construir as infra-estruturas para armazenar o produto. Por outro lado, essa mesma empresa traça outro mecanismo de subordinação imposto aos agricultores. Trata-se do comércio de defensivos e serviços agrícolas necessários ao produtor. Nessa ponta do processo produtivo o grupo Bunge atua com as empresas da Bunge Fertilizantes. Esta controla parte significativa do setor. Nos cerrados piauienses sobram poucas opções aos agricultores, pois a empresa os cerca estabelecendo uma intricada relação de

\footnotetext{
91 Ás vezes a soja armazenada nos silos desses estados (principalmente a de Tocantins) é enviada também para a planta de fábrica de Luis Eduardo Magalhães - BA, conforme mapa 14.

92 Informações obtidas através de entrevista realizada a funcionários administrativos da unidade de Uruçuí, em janeiro de 2006.
} 
compra do produto agrícola, venda de defensivos e serviços e, ainda, de empréstimos nos mesmos moldes do sistema bancário, porém o pagamento não ocorre em dinheiro, mas em produto, através do programa que mencionamos anteriormente conhecido como "Soja Verde". 
Mapa 14: Presença da Bunge Alimentos nos Cerrados Nordestinos: Fábricas, Silos e sua Àrea de Influência

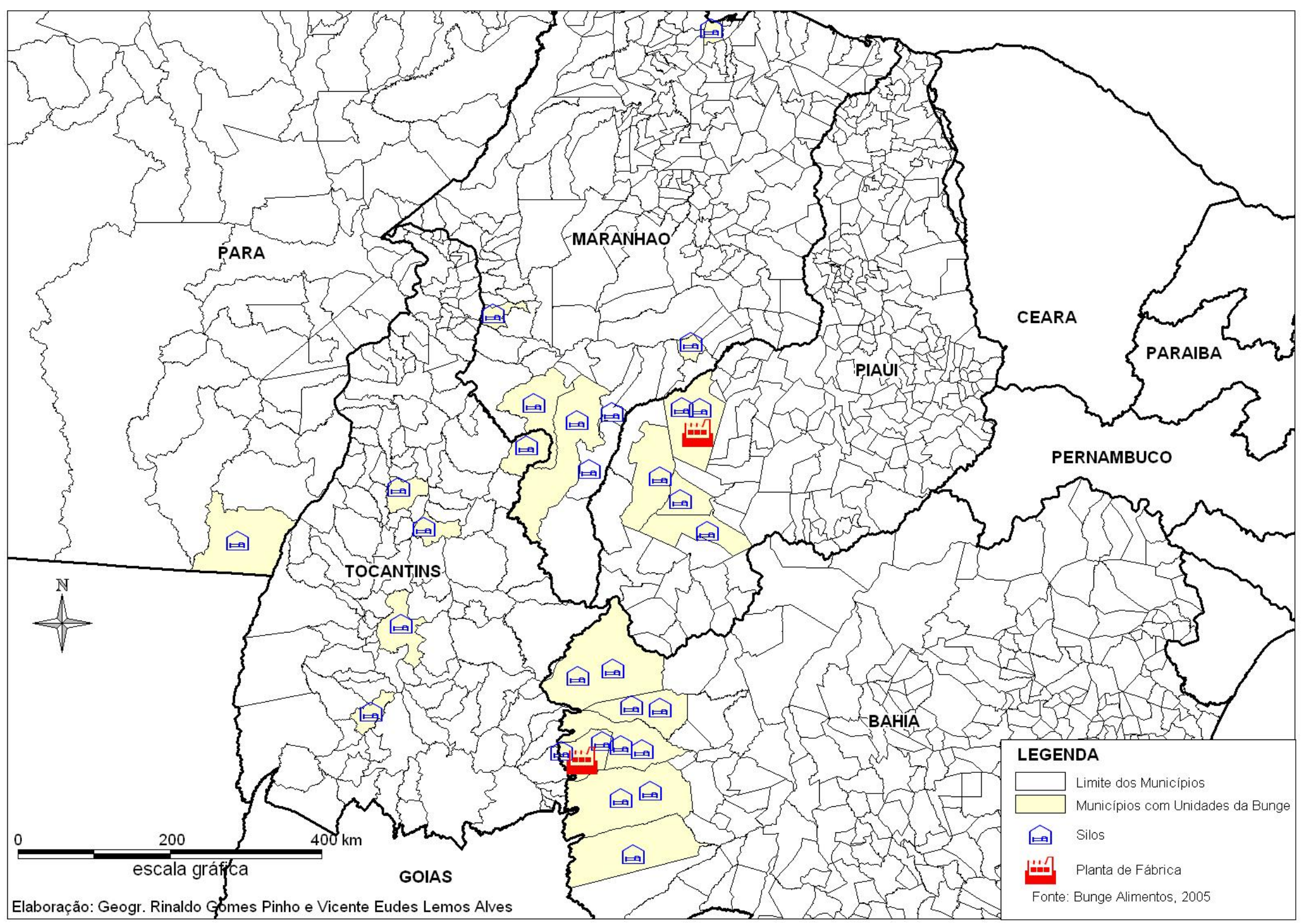


A situação pela qual passou a Cotrirosa, e seus colonos, mostra, claramente, os tipos de mecanismos adotados por uma grande empresa interessada em tirar de cena os grupos correntes menores.

A cooperativa montou uma unidade de secagem e de armazenamento destinada a atender à produção dos cooperados, não somente de soja, mas de outros produtos, como o arroz. Mas, como vimos, o projeto de implantar o sistema de cooperativismo nos cerrados piauienses foi abortado no meio do caminho. A Bunge se aproveitou dos problemas enfrentados pela cooperativa para se apoderar, a baixos custos, de suas instalações (foto 31). Após a concretização dessa etapa de eliminação da concorrência, partiu para fincar novas bases de relacionamento com o produtor colono, subordinando-o em todas as esferas econômicas. Se antes havia a participação dos colonos nas decisões dos rumos da cooperativa, mesmo que existissem problemas, com a Bunge essas iniciativas desapareceram. Os espaços de decisão tornam-se totalmente verticalizados pela empresa que passa a ditar suas regras. Além disso, a empresa aumenta substancialmente o grau de exploração de seus novos empregados diretos ou de seus fornecedores, na medida em que com a redução ou com o desaparecimento da concorrência torna-se mais fácil impor as estratégias de vencedora.

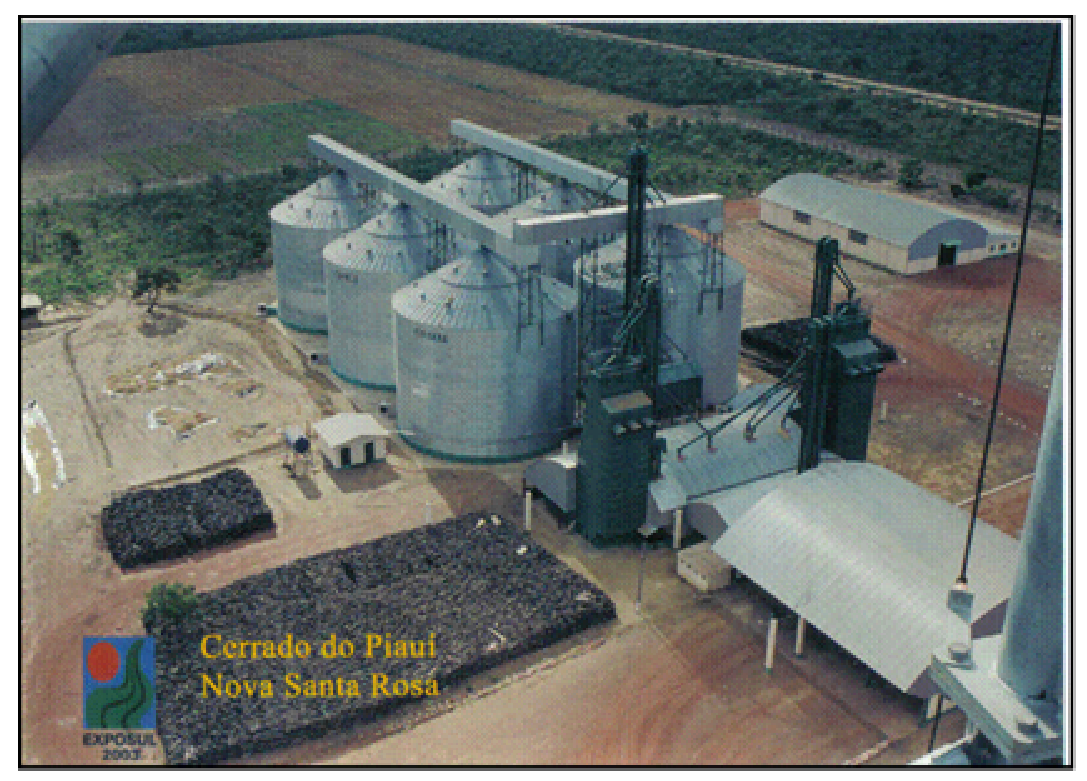

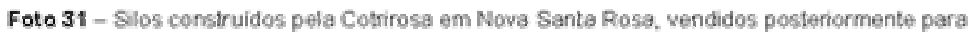
Bunge Airments: Fololab, junto de 2003. 
A relação da Bunge com os antigos cooperados da Cotrirosa passa a ocorrer, a partir de então, dentro dessas regras. No entanto, para o produtor/fornecedor, apesar de perceber o distanciamento de tratamento na relação com a grande empresa (agora já não é a "nossa cooperativa", como fica claro nos depoimentos de alguns colonos), ele ainda enxerga na nova relação com a grande empresa uma pretensa liberdade, pois ao seu ver pode procurar qualquer outro concorrente para comercializar seu produto. Segundo se observa nas declarações de um morador de Nova Santa Rosa:

“(...) isso é aberto, você pode vender para qualquer um, para qualquer multinacional: a Bunge, a Cargill (...). Pode vender para qualquer produtor, para qualquer pessoa, isso é livre (...)"

(Entrevista concedida por migrante sulista em setembro de 2003)

Se não voltarmos um olhar atento sobre essas palavras, podemos até acreditar que, realmente, o produtor/fornecedor é livre para comercializar sua produção com quem the desejar, não havendo qualquer restrição dessa liberdade. É como se o trabalhador de posse de sua mercadoria, força-detrabalho, pudesse se mobilizar em busca de quem the pagasse mais pelos seus serviços. Não é isso, entretanto, o que ocorre. $O$ trabalhador é mobilizado para aqueles mercados de demanda de força de trabalho pelos mais diversos procedimentos, mas chegando ali há um rebaixamento do preço de sua única mercadoria disponível, a própria força de trabalho. O mesmo ocorre com aquele produtor/fornecedor que se sente livre para vender seus produtos para qualquer mercado, mas ao final percebe que não existem tantos compradores assim, pois a grande empresa tratou de o cercar todos os lados, não havendo muitas alternativas para exercer de fato a forma "ideal" de reprodução do capital através da oferta e da procura.

Numa entrevista com outro migrante da agrovila de Nova Santa Rosa, ele me relatava que, daquilo que fora obrigado a entregar a Bunge pelo contrato de Soja Verde, havia sobrado sete mil sacas do produto em seu galpão, mas teve dificuldades em vendê-las, pois aquela empresa estava aumentando sua participação no mercado nordestino com farelo de soja, 
reduzindo suas chances de achar outras empresas interessadas em adquirir 0 seu produto; conforme aparece no relato:

"Aqui nós temos contrato de 35 sacas por hectare. Aí tinha botado debaixo do galpão 7.000 sacas que deu a mais, esse aí foi vendido para outro. Só que agora a Bunge já está vendendo farelo no comércio interno do Nordeste, estragando nosso negócio. Por isso, o resto ficou empenhado ali [...] Se tivesse vendido logo na safra teríamos ganhado em média seis reais a mais por saca. Agora com isso está dois a três reais de diferença".

(A.S., morador em Nova Santa Rosa. Entrevista concedida em setembro de 2003).

As poucas alternativas existentes de encontrarem outros compradores, a não ser vendendo para as demais grandes empresas do mesmo ramo econômico, como a Cargill, e as restrições colocadas para obter empréstimos de bancos oficiais forçam esses produtores a participarem do "pacote" de financiamento da Bunge. Ou seja, passam a se atrelar à empresa não somente como fornecedores de soja, mas como também compradores dos insumos necessários à lavoura que são fornecidos pela Bunge Fertilizantes, tida como a maior do mundo nesse setor. Em 2003, os contratos firmados entre os produtores e a empresa estabeleciam que, além de adquirirem os insumos da própria Bunge, os produtores teriam de obter de suas lavouras uma produção mínima que, naquele momento, era de 35 sacas por hectare. A soja que no mercado interno estava cotada, em média, a 34 reais a saca, saía para a Bunge por 24 reais. Percebe-se, assim, que, ao fazer o adiantamento, a empresa embutiu um outro mecanismo de taxa de juros. Por vezes, a safra adquirida dos produtores é vendida no mercado interno pela própria Bunge a uma cotação, em outubro de 2004, de 32 reais a saca. A empresa ganha, dessa forma, nas duas pontas do processo, pois recebe do produtor abaixo do preço médio do mercado e vende posteriormente com um preço acima do que se paga, isso também porque, como possui grandes unidades de armazenamento, pode estocar seu produto para vender quando os preços estão melhores. A liberdade do produtor, nesse sentido, é fictícia, pois não existem tantas outras opções de comercializar a não ser com os poucos grupos econômicos hegemônicos; como retrata o depoimento abaixo: 
"Aqui no momento é preciso acabar com o monopólio de uma empresa no financiamento, por isso eu volto a insistir nessa questão do crédito oficial. Hoje praticamente a região é movida a crédito de uma única empresa que atua na área de grãos. Estão também desenvolvendo o papel de agente financeiro com um custo muitas vezes maior do que o custo de crédito oficial. Hoje nós teríamos num financiamento de custeio agrícola taxa média de $28,75 \%$ ao ano. Enquanto que o crédito dessas empresas é até mais facilitado, mas a um custo aí de 25, 30 até 40\% ao ano. O que seria a margem de lucro do produtor é canalizada toda para essa multinacional. Então, hoje sabemos que o setor de grãos está todo ele nas mãos das multinacionais, mas aqui enfrentamos um problema ainda mais grave que é a falta de concorrência entre eles. É um monopólio mesmo. Então, não havendo alternativa de tentar o crédito junto ao concorrente é ir morrendo aos poucos, atrelando nossa produção a essa empresa"

(M.P.C., gaúcho recém instalado nos cerrados piauienses. Entrevista concedida em setembro de 2003).

Evidenciam-se, dessa maneira, os mecanismos adotados Bunge Alimentos para a reprodução de seu capital. Ao mesmo tempo em que ela é uma empresa que usa o discurso de modernidade, pautando-se pela idéia de eficiência no gerenciamento administrativo e nas modernas instalações das plantas de fábrica, com equipamentos de última geração em tecnologia, poupadores de mão-de-obra, encobre determinadas relações com aqueles que trabalham para que a grande empresa possa obter matéria-prima destinada à produção de mercadorias a serem colocadas em circulação no mercado mundial.

Aquele discurso de modernidade não é condizente com a realidade, do mesmo modo, no que se refere à questão ambiental, como veremos a seguir.

\section{2 - A presença da Bunge Alimentos e de outras empresas nos cerrados piauienses e a questão ambiental}

É característico das grandes empresas atualmente articular um discurso de preservação ambiental com campanhas publicitárias voltadas para a sociedade ou destinarem algum recurso financeiro para aquelas entidades dedicadas a essa causa, como determinadas organizações nãogovernamentais (ONGs). As grandes empresas freqüentemente forjam uma situação em que se colocam como as guardiãs do ambiente natural. A própria 
Bunge possui um departamento no organograma da empresa que se dedica unicamente à questão ambiental. A empresa recebe, inclusive, homenagens de entidades ambientalistas por suas pretensas iniciativas nesse setor. É o caso, por exemplo, do prêmio "Flitz Muller" da Fundação do Meio Ambiente (Fatma), do governo de Santa Catarina, concedido a Bunge pelo reconhecimento de sua pretensa contribuição "às melhores práticas na defesa da natureza e da qualidade de vida dos catarinenses" $"$.

Essa preocupação de preservação ambiental, no entanto, não encontra sintonia com a sua prática desenvolvida nos cerrados piauienses. Esta prática se sustenta na lógica da apropriação dos recursos naturais sem qualquer "crise de consciência". Projeta a visão daqueles recursos como uma fonte de ampliação dos lucros, não importando quais impactos acarretarão sobre o ecossistema e sobre a população que sobrevive dele.

É característico também do grande capital desenvolver de imediato, nos lugares em que se instala, um discurso mistificador da modernidade; com ele, tenta-se mostrar que a presença de uma grande empresa num determinado lugar representaria a felicidade de todos, na medida em que pretensamente todas as pessoas teriam acesso às riquezas produzidas. No caso piauiense, a Bunge representaria para os cerrados o símbolo do progresso numa área carente de modernização. Tal imagem, no entanto, não condiz com a forma pela qual a empresa utiliza os recursos naturais dessa sub-região dos cerrados. A empresa chega ao Piauí, mas não sem antes realizar uma ampla rede de articulação que julgou necessária para não sofrer muitos impedimentos em seu projeto de ampliação dos lucros no estado. Antes de instalar a planta de fábrica em Uruçuí, ela financiou a campanha eleitoral de vários políticos, candidatos a cargos dos poderes executivos e legislativos, estadual e federal, de distintas filiações partidárias. O poder público estadual concedeu à empresa 15 anos de isenção do ICMS, além de outras vantagens fiscais e de melhoramento de infra-estruturas viárias e energéticas. Atualmente, a empresa possui, no estado, simpatizantes, que ocupam cargos no legislativo estadual e executivo, e são os principais defensores de adequação das leis,

\footnotetext{
${ }^{93}$ Revista Bunge Planeta, ano 03, número 32, agosto de 2005.
} 
principalmente ambientais, para garantir a presença da empresa nos cerrados piauienses.

Em outros segmentos, o de empresários de lojas agrícolas e o de proprietários e/ou especuladores de terras, exalta-se 0 discurso das oportunidades de novos negócios trazidas pela empresa, pois ela intensificou o comércio de maquinários e de insumos e a valorização das terras. Nos anúncios de vendas de terras veiculados hoje no sul do Piauí trazem, necessariamente, a informação de que distância o local se encontra das unidades de recebimento ou da fábrica esmagadora de soja da Bunge. A partir de sua instalação no sul do Piauí, o mercado imobiliário de terra agrícola passa a se regular pela distância das instalações da empresa.

A questão mais grave, no entanto, após a instalação da empresa no sul do Piauí, refere-se aos impactos ao ambiente natural, com uma capacidade avassaladora de destruição do bioma dos cerrados, principalmente, de sua vegetação, que vem servindo de fonte energética para o aquecimento das caldeiras da fábrica esmagadora de soja. A empresa sofre tal acusação pelos ministérios públicos, federal e estadual, inclusive com execução de processos judiciais que tratam da exploração de uso de madeira dos cerrados. As acusações apontam que a fábrica da Bunge adota práticas inadequadas no uso da matriz energética; ao invés de gás ou outras fontes energéticas - mais onerosas financeiramente para a empresa, mas com menos impacto sobre 0 meio ambiente local - adotou-se o uso da lenha das matas nativas de cerrados $^{94}$. Calcula-se que, para manter o atual ritmo de produção, a empresa deverá consumir 11.021 quilos ou 27,5 metros cúbicos de lenha por hora, correspondendo a 217,5 milhões de metros estéreis por ano, ou 10.876,7 hectares/ano (Isto é/Funáguas). Paga-se, em média, 0,60 centavos de real aos trabalhadores rurais para cada metro cúbico de lenha recolhida, enquanto a Bunge desembolsa 22 reais pelo metro estéril de lenha aos detentores desse comércio. Esse lucrativo negócio produziu um grande interesse dos produtores de soja que passaram a desmatar suas áreas também com o objetivo de

\footnotetext{
${ }^{94}$ Numa reportagem, com o título "O cerrado vira lenha", de 08 outubro de 2003 ( $\left.n^{\circ} 1775\right)$, a revista Isto É trazia uma ampla denúncia sobre a instalação da Bunge no Piauí e o uso da lenha como principal recurso para o aquecimento de suas caldeiras.
} 
comercializar lenha para a Bunge, agravando ainda mais a situação das matas nativas de cerrado.

A outra opção vislumbrada pela empresa para abastecer suas caldeiras é o eucalipto. O uso dessa fonte energética, no entanto, somente será disponibilizada nos próximos anos, quando os primeiros reflorestamentos de eucaliptos da área, que se iniciaram em 2002/2003, estiverem prontos para o corte, com previsão para 2007/2008. Mas há também restrições ambientais ao aproveitamento dessa planta para o reflorestamento de antigas áreas de matas nativas, tendo em vista a grande capacidade que ela possui de comprometimento dos lençóis freáticos. Além disso, pode introduzir novas pragas por conta dos extensos plantios homogêneos e contínuos, o que causariam maiores prejuízos para o meio ambiente local.

Visando uma menor exposição de seu nome em escândalos ambientais, a Bunge terceirizou os serviços de fornecimento de lenha da vegetação nativa, encarregando de tal tarefa a Mineradora Graúna, empresa do grupo Canel (Central Agrícola Nova Era), parceira da Bunge no Piauí, em cujas terras está instalada a planta de fábrica de esmagamento de soja. A Canel é também proprietária de um dos silos arrendados para armazenar soja comprada pela Bunge. A Graúna fornece, ainda, calcário aos produtores atrelados à grande empresa, como parte do "pacote" que lhes foi imposto para financiar suas lavouras de soja. Ocorrem denúncias contra essa mineradora que, por sua vez, contrata de maneira irregular trabalhadores locais para a derrubada da mata, pagando a eles preços aviltantes pela madeira retirada. A Canel é uma das empresas citadas no relatório de fiscalização do Ministério do Trabalho e do Emprego por descumprir leis trabalhistas com seus empregados nos cerrados piauienses.

Vê-se, assim, que o capital estabelece diferentes estratégias para se apoderar indiscriminadamente não somente dos recursos naturais, mas da própria força de trabalho de pequenos produtores que, diante das condições de vida oferecidas, não possuem outras alternativas senão a sua própria entrega aos ditames do capital. As empresas vencedoras, por sua vez, quanto mais reduzem o número de seus concorrentes, menos procuram se colocar à frente de situações em que comprometam a sua imagem perante os consumidores, protegem-se, desse modo, por meio de outros grupos econômicos 
subordinados a elas, os que realizam, digamos, o "trabalho sujo". São essas empresas globais, entretanto, as que verdadeiramente lideram tais ações e as que mais se beneficiam da maximização da exploração tanto do trabalhador expropriado quanto dos recursos naturais. O discurso, porém, que se tenta construir pela e para a grande empresa é o de que ela se preocupa com a degradação ambiental, freqüentemente disseminando falsas promessas de defesa da natureza. Os problemas ecológicos produzidos pela racionalidade monetária empresarial de maximização dos lucros com minimização das despesas incidem sobre o capital privado, mas diretamente em custos a serem absorvidos pelos suportes do Estado.

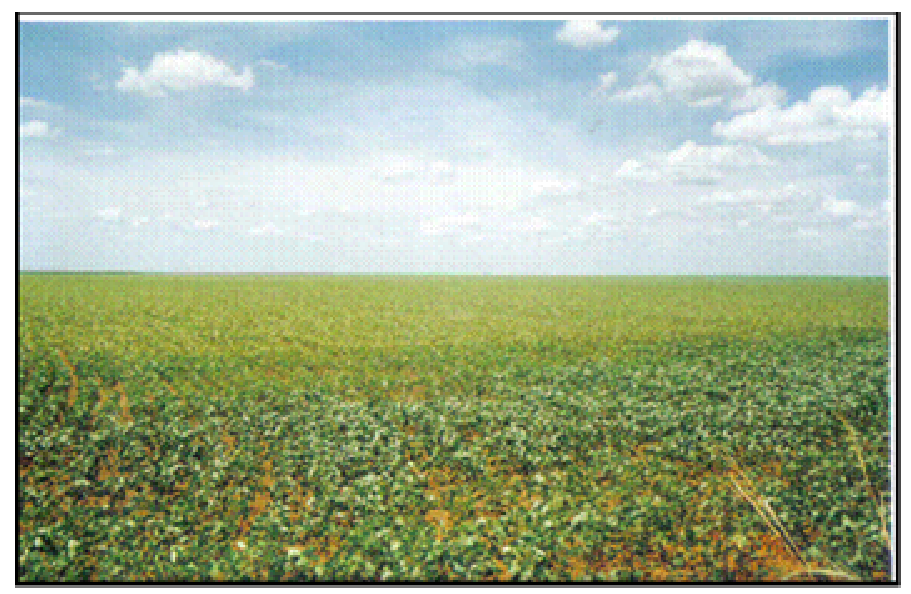

Foto 32 - Campos de soja no municipio de Uruçu - o espaço de produça ganha gada wez mais homogeneidade Foto do autor janeiro de 2006 .

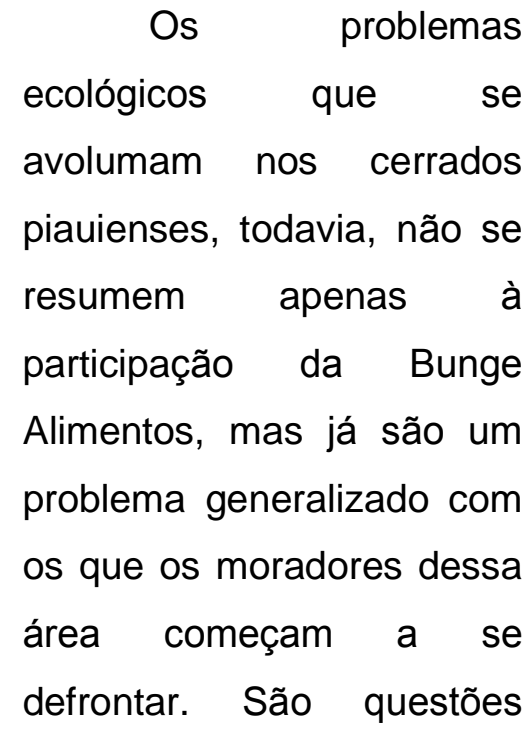

visíveis não somente nos platôs dos gerais, onde a vegetação nativa cede rapidamente lugar para as grandes lavouras de soja (foto 32), com prejuízos incalculáveis para as nascentes dos principais rios da região, mas também nos fundos de vale, onde ocorrem as vazantes, domínio fundamental para a reprodução da vida de populações camponesas do sul do Piauí. Percebe-se a ampliação do impacto ambiental pelo acelerado processo de assoreamento dos principais rios da bacia do Parnaíba, como o Gurguéia (foto 33), o Uruçuí Preto e o próprio Parnaíba. Os moradores mais antigos dos cerrados piauienses se assustam com o poder de destruição dos ambientes naturais produzido pelo agronegócio. Os impactos que se registram tanto nas transformações das formas de vida locais (rural e urbana) quanto nas dinâmicas ambientais são motivos de incertezas por parte desses moradores diante dos novos processos 
de modernização, apontados como tábua de salvação dos problemas anteriores dessa área. As carências econômicas, todavia, persistiram ou se ampliaram com a modernização contemporânea. Além disso, os recursos naturais que complementavam o sustento daquela população com menos disponibilidade de dinheiro tornam-se ainda mais escassos.

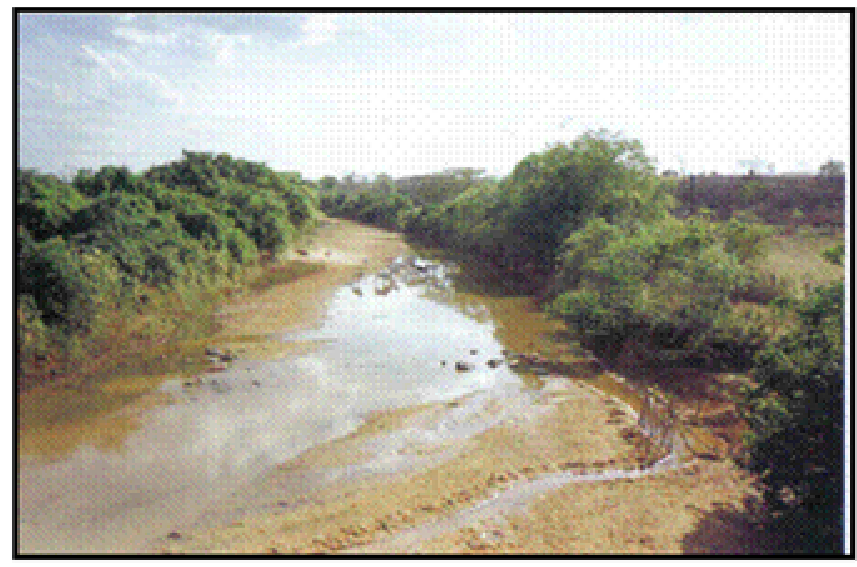

Foto 33 - Rio Gurgueia - o problema do assoreamento se agravou nos útimos anos com a ocupaço dos gerais. Foto do autor, outubro de 2006
O avanço das
lavouras de soja nos platôs
evidencia a aceleração do
desmatamento em tais
domínios. Os registros de
imagens de satélites deixam
claro que a expansão da
área agrícola ocorreu de maneira mais significativa a partir dos anos 1990, principalmente nos platôs da

Serra de Uruçuí. Conforme as figuras a seguir, apontando três momentos históricos de ocupação do solo dos municípios de Bom Jesus (figura 02) e de Uruçuí (figura 03), verifica-se que antes de 1990 pouco se manifestavam práticas de agricultura nessas áreas, as quais se mantinham fortemente preservadas. Esse quadro, no entanto, se altera substancialmente nos anos seguintes, principalmente a partir de meados daquela década quando se intensifica o desembarque de agricultores capitalistas modernos. 
Figura 02: Evolução do uso do Solo no Município de Bom Jesus - Piauí

\section{Ano 1990}
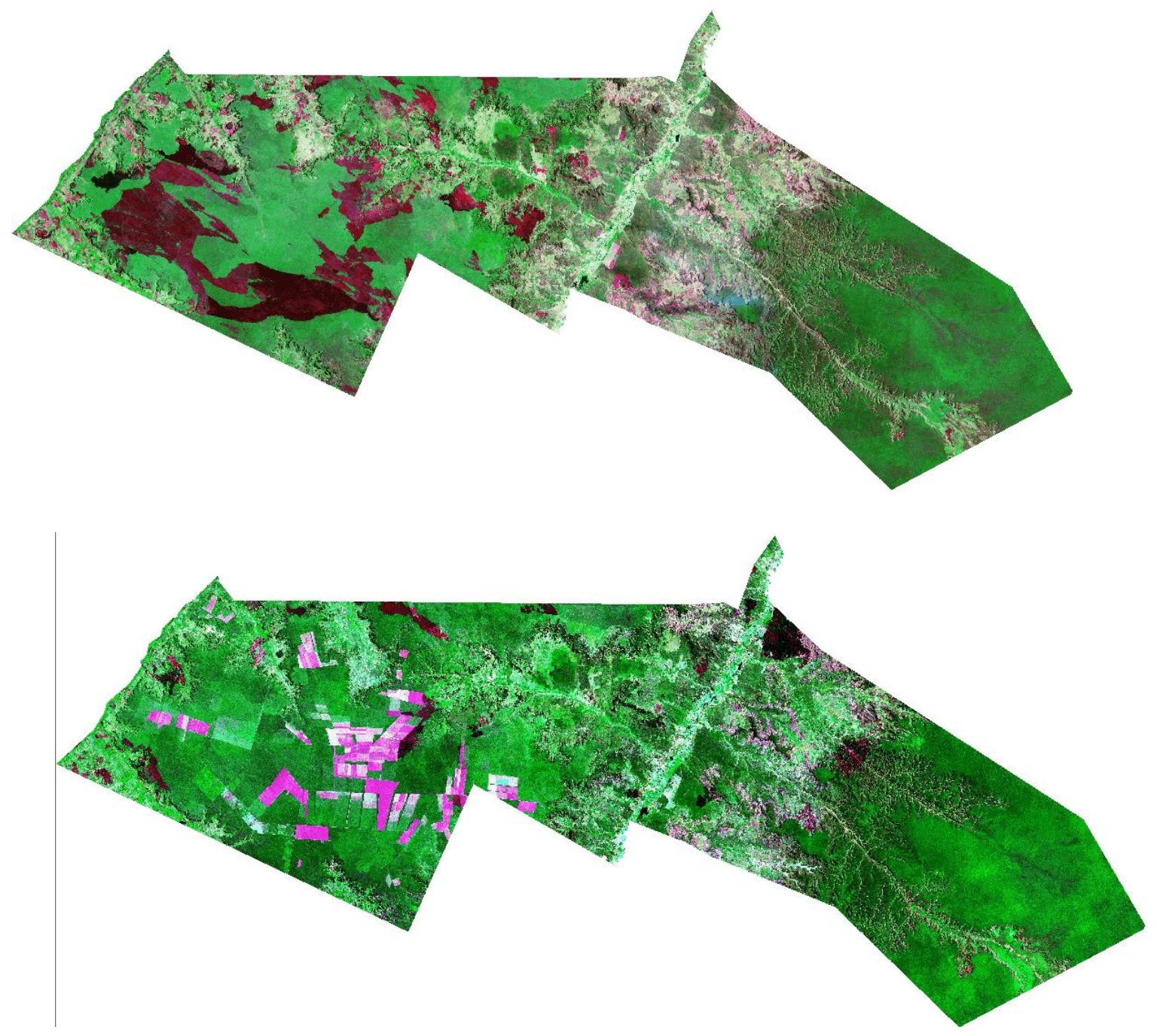

Ano 2004

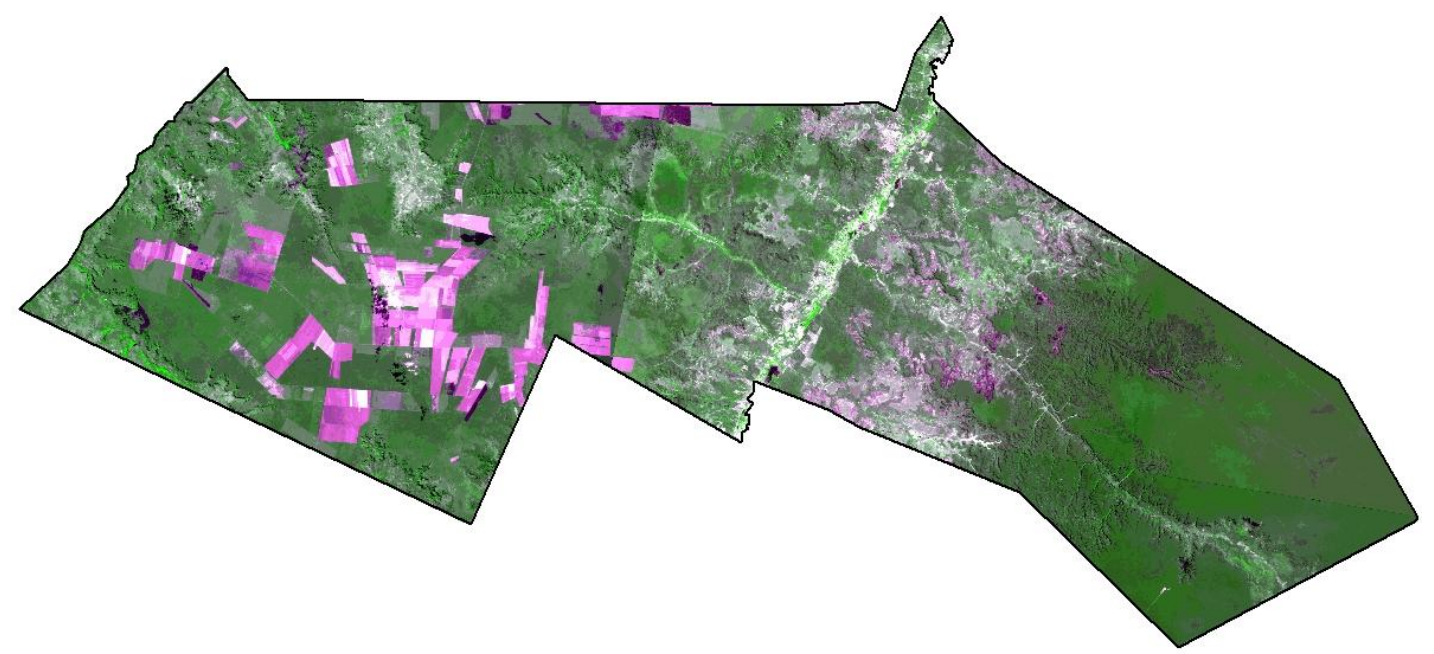

Fonte: Secretaria do Meio Ambiente e Recursos Naturais do Piauí. Mosaico de Imagens dos Satélites Landsat e CBERS-2 
Figura 03: Evolução do Uso do Solo no Município de Uruçuí - Piauí

Ano 1990

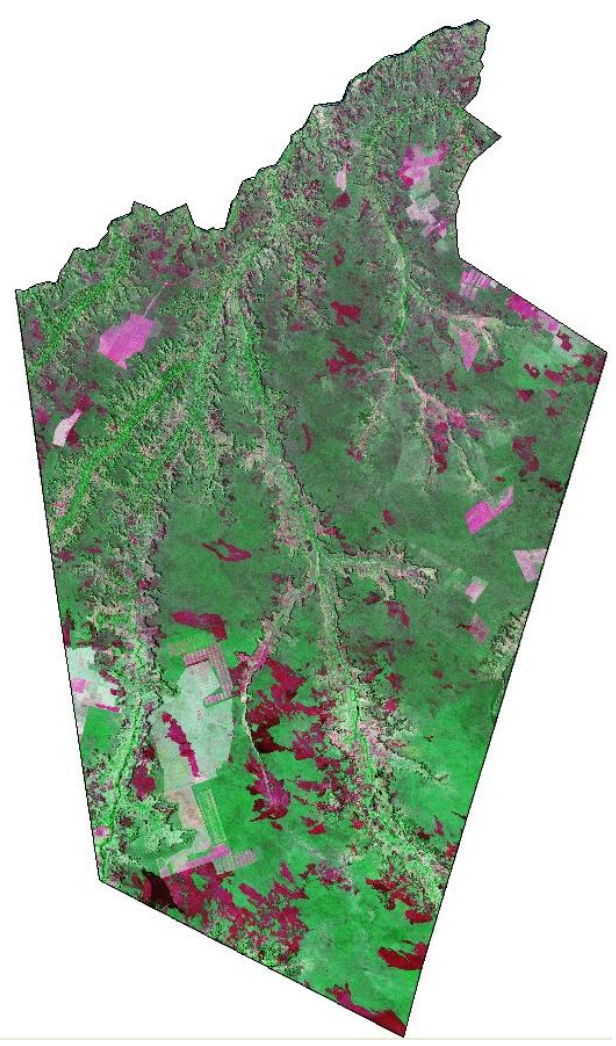

Fonte: Secretaria do Meio Ambiente e

Recursos Naturais do Piauí

Mosaico de Imagens dos Satélites Landsat e CBERS-2
Ano 2000

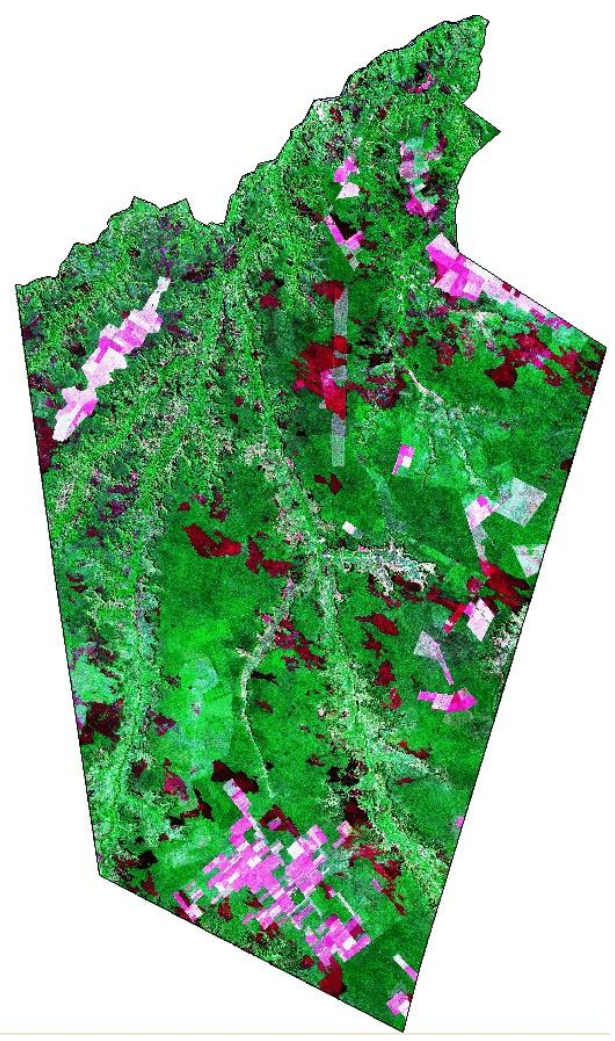

Ano 2004

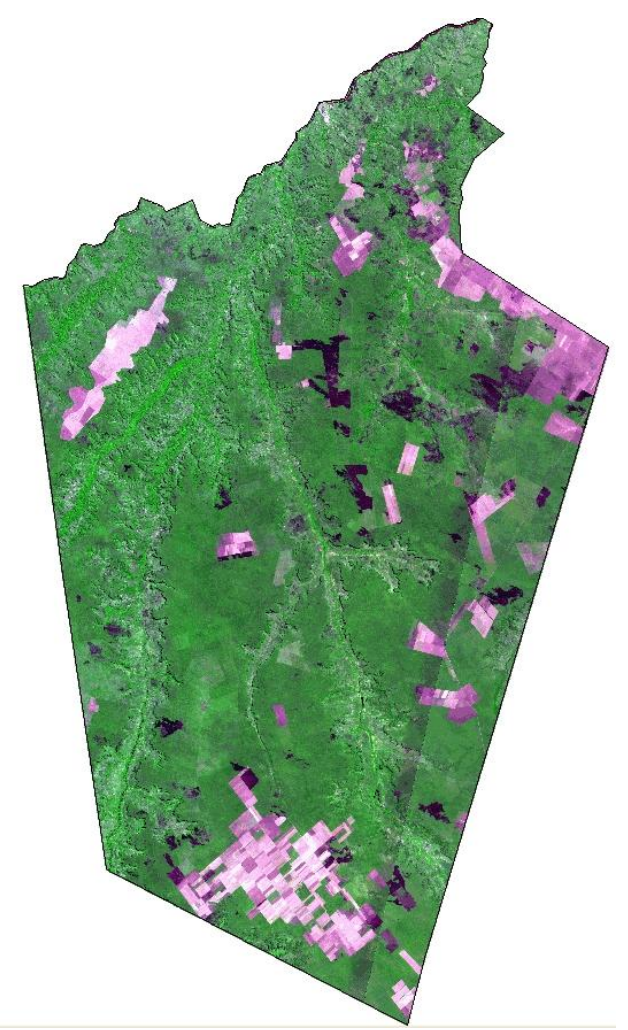


Em 2000, percebe-se um crescimento das lavouras em que as formas na paisagem na paisagem indicam a intervenção de novos processos produtivos na dinâmica natural dessas áreas. Embora se identifique em tais figuras uma dilatação do desmatamento entre 2000 e 2004, a expansão da área ocupada com agricultura nesse período ocorreu mantendo a continuidade com os focos de ocupação já existentes em 2000, mas também aparecem indícios de novos núcleos de ocupação sendo formados. Esse fato apresenta evidências de que aquela ocupação se faz de maneira induzida pela especulação imobiliária, em que a intenção dos agentes econômicos desse setor seria a de primeiramente garantir a valorização de áreas especificas dos platôs, para depois ampliá-la em direção outras, conforme vá havendo uma maior procura por terras. A constituição do mercado imobiliário nos cerrados piauienses torna-se, portanto, um fator relevante para a compreensão do movimento recente de ocupação daquela área.

A análise das figuras aponta também para o fato de que a expansão agrícola nos platôs ocorre nas proximidades dos afloramentos de nascentes dos principais cursos d'água da região, produzindo impactos generalizados no meio físico e nas comunidades humanas, principalmente aquelas que habitam os baixões, domínios abastecidos com a água que emerge nos platôs. Além disso, houve uma substancial redução de espécies da flora e da fauna por conta da eliminação de toda a cobertura vegetal onde ocorrem os cultivos.

Esse problema se agrava, na medida em que o agronegócio continua em pleno vapor nos cerrados piauienses. Apenas em Bom Jesus, os cálculos do Inpe (Instituto Nacional de Pesquisas Espaciais) apontavam que entre 2002 e 2004 a área ocupada com a agricultura moderna passou de 12.582 hectares para 78.717 hectares, ou seja, uma variação de expansão de $625 \%$, com previsão de maior crescimento para os próximos anos. Tal avanço dos cultivos da agricultura moderna, que por enquanto ocorre nos platôs planos, apresenta reflexos ambientais negativos também sobre os baixões, o que acarreta problemas na mesma intensidade para os moradores dessas áreas. Nos últimos anos, tal população vem observando uma diminuição da vazão de água dos riachos por conta da eliminação das nascentes nos platôs, problema que se avoluma com o assoreamento dos cursos d'água decorrentes da erosão produzida, na área de cultivo, com o desmatamento (fotos 34 e 35). O impacto 
mais grave, no entanto, que sofre a população dos baixões é com a contaminação da água e do ar pelos agrotóxicos pulverizados por aviões e máquinas agrícolas sobre as lavouras modernas, mas que atingem os vales, envenenando pessoas e animais em amplas áreas da região. Constata-se, ainda, que a intensificação do uso de agrotóxicos reverteu-se em proliferação de determinadas pragas destruidoras das pequenas lavouras dos camponeses.

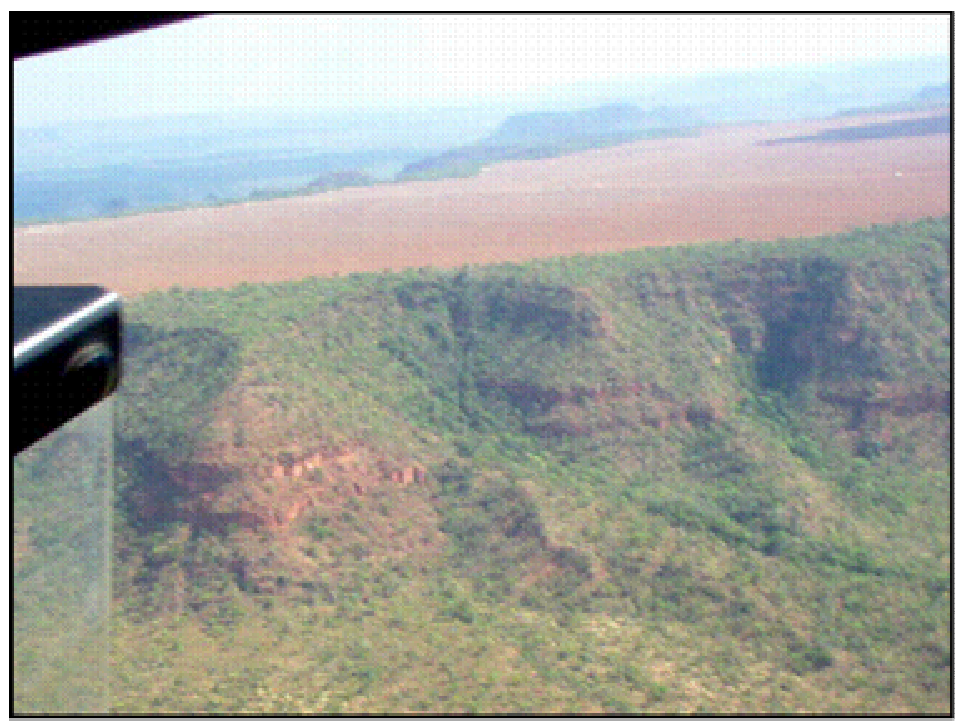

Fotos 34 = Desmatamento ate o imite das bordas dos tabuleiros, pratica que intensifica os processos erosivos e os niscos de desaparecintento dos nascedouros dos cursos dagua em gerais de Balsas lbama, 2005.

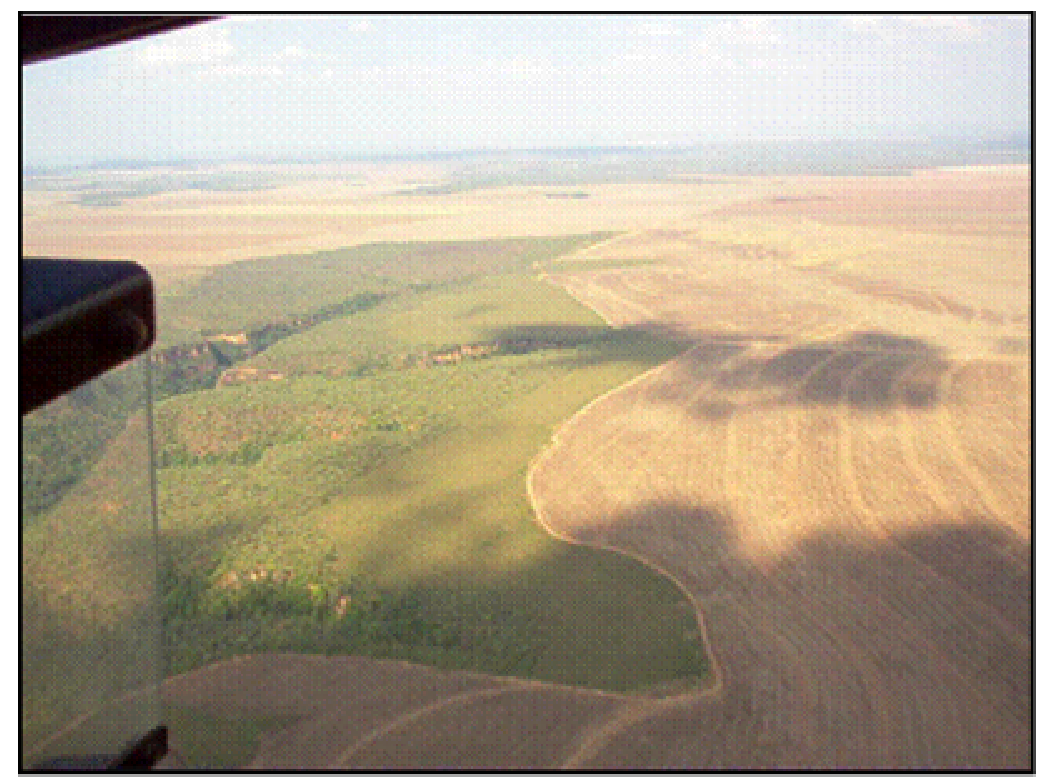

Fotos 35 - Ocupaça das bordas dos tabuleiros lbama, 2005 . 
A contaminação por agrotóxicos após a instalação da agricultura capitalista moderna alcança várias comunidades de pequenos produtores rurais nos cerrados, representando atualmente um grave problema para aquela população. Além de seus ambientes de vida serem atingidos por uma carga elevada de venenos colocando todos os moradores em situação de risco, os trabalhadores das grandes lavouras também se ressentem da exposição diária à pulverização de agrotóxicos, produzindo efeitos nocivos à saúde dessas pessoas. As denúncias de trabalhadores com sintomas de intoxicação e problemas respiratórios decorrentes do contato com o veneno e da falta de equipamentos de proteção se espalham por toda a região dos cerrados nordestinos. Em 2005, foram denunciados os primeiros casos no sul do Piauí de morte de trabalhadores por envenenamento com agrotóxicos. A situação mais grave ocorreu no município de Ribeiro Gonçalves, onde se creditam quinze mortes de trabalhadores, naquele ano, por conta de contaminação contraída através dos venenos pulverizados nas plantações agrícolas modernas (O Estado de S. Paulo, 27/10/2005). Esse fato mostra que a crise é uma parceira inseparável do crescimento econômico capitalista piauiense, sustentado (agora) na produção de novas mercadorias agrícolas.

O clima também sofre os primeiros reveses por conta da expansão avassaladora do agronegócio no sul do Piauí. Os registros meteorológicos já registram um aumento sensível da temperatura nos municípios dos cerrados, o que, por conseguinte, influencia também no regime de chuva apresentando atualmente, em comparação com anos anteriores, portanto com uma maior irregularidade. Em Bom Jesus, em 2005, as temperaturas no meio urbano se ampliaram, ultrapassando os limites constatados em outros momentos. Tais fatos são elucidativos de que a população dos cerrados piauienses se defronta com novas questões também no que se refere à dinâmica ambiental. A destruição acelerada do "patrimônio natural" piauiense levada a diante pelo princípio absoluto da racionalidade capitalista consiste na impossibilidade de outros usos futuros desses ambientes. O custo ecológico que incide sobre o estado e o conjunto da população dos cerrados piauienses representa, portanto, um outro sintoma da crise, pelo que as empresas vencedoras são as principais responsáveis. A exploração desmedida da força de trabalho por tais 
empresas também, como vimos, resulta em custos sociais elevados, levando grandes contingentes da população local à miséria.

Vê-se, assim, que a promoção de alguns produtores ou empresas à categoria de vencedores somente ocorre às custas de amplas parcelas de perdedores. É com essa lógica excludente que os processos de aceleração da modernização capitalista se sedimentam nos cerrados piauienses nos últimos anos. 


\section{CONSIDERAÇÕES FINAIS}

O impulso à produção de mercadorias agrícolas nos cerrados piauienses é o responsável pelas principais mudanças estruturais engendradas nas últimas décadas naquela área. Tal movimento que se organiza sob a insígnia do mercado global busca, a partir da totalização da forma mercadoria, homogeneizar os elementos necessários à reprodução do capital. O tempo único que busca se instalar, ditado pela economia de mercado, sobrepõe-se às outras formas de relações que não seguem os parâmetros exclusivamente fundados no automovimento do dinheiro. $O$ trabalho que resulta da mediação do homem com a natureza torna-se, dessa maneira, cada vez menos presente como forma de reprodução social, dificultando os indivíduos de se reproduzirem a não ser pelo trabalho abstrato. Freqüentemente, nem mesmo essa via se coloca como possível, na medida em que faltam os meios produtivos necessários para que ocorra a exploração da força de trabalho.

Esse percurso impositivo da forma mercadoria que destrói as outras experiências de produção da vida não se faz, entretanto, de uma só vez, mas por um movimento permanentemente contraditório. Nesse sentido, apesar dos processos de modernização imprimirem velocidade nas transformações daquela sociedade em busca de um tempo único de produção, não se esgota automaticamente as formas vigentes anteriormente, elas permanecem, sem necessariamente serem substituídas completamente por um determinado tempo imposto pelas novas forças modernizadoras. A produção de mercadorias agrícolas destinadas ao mercado local e à subsistência da família camponesa, por exemplo, ainda se mantém nos cerrados piauienses e é responsável pelo adiamento de uma exclusão absoluta de seus representantes. Mas, são as lavouras modernas de grãos as que se transformam cada vez mais em vencedoras diante de uma corrida desigual entre as duas formas de produção. Essas distinções na maneira como cada um desses grupos se apropria dos instrumentos atuais de reprodução capitalista confirmam que a não-simultaneidade é decisiva para a ampliação dos contrastes sociais locais e, por conseguinte, geradora das mesmas formas globais de crise produzidas pelo sistema produtor de mercadorias. Ocorre, nesse sentido, nos cerrados 
piauienses, uma simultaneidade negativa da crise que acomete o sistema em sua totalidade.

Por um lado, os produtores agrícolas de grãos e as grandes empresas transformam seus empreendimentos em êxitos econômicos a partir do uso de equipamentos tecnológicos sofisticados, da disposição de estruturas de escoamento que permitem impor velocidade ao transporte das mercadorias e, ainda, da capacidade de requisitar trabalho e terra pagando por eles os preços que Ihes convêm, às empresas. Por outro lado, os camponeses se sustentam com rudimentares instrumentos de produção e meios de transporte de suas mercadorias, além de serem transformados em vendedores precarizados de sua força de trabalho. Os representantes da primeira situação transformam-se em ganhadores momentâneos no jogo do mercado, cujo prêmio se reverte em acumulação na forma de bens (dinheiro, terras, maquinários, automóveis, residências etc.); os da segunda, são expropriados e atirados em meios urbanos com a tendência a ficarem excluídos do processo de acumulação. O Estado aparece nesse ínterim garantindo, aos primeiros, instrumentos jurídicos legais em forma de benesses fiscais ou do aparato coercitivo militarizado; aos segundos, sistemas de ajuda para amortecer minimamente a sua condição de indivíduos fragilizados por conta da destituição de seus meios de sobrevivência.

Os processos atuais de modernização resultam, dessa maneira, em permanentes descompassos sócio-econômicos. Nesse caso, a maior adesão dos cerrados piauienses ao moderno sistema produtor de mercadorias sob o domínio das formas monetarizadas consiste, naquela área, em elementos potenciais geradores de crise, como alguns do que se anunciam, a saber:

- A produção de grãos, sobretudo a soja, está subordinada ao mercado mundial e a um conjunto de empresas globais vencedoras da concorrência, incapacitando outras empresas e indivíduos da economia local de se manterem autonomamente. A adoção de aparatos tecnológicos avançados poupadores de força de trabalho, do mesmo modo, resulta em ampliação da massa de perdedores, constituída por levas de trabalhadores sem trabalho assalariado. Atribui-se, ainda, o fato de que a exigência do mercado pelo aumento da produção e da produtividade agrícolas redunda em custos ecológicos sem precedentes aos ecossistemas dos cerrados piauienses. Além de retirar da 
população camponesa local suas fontes de sobrevivência, o uso indiscriminado de agrotóxicos por parte da agricultura moderna coloca em risco a saúde daqueles indivíduos, como os inúmeros casos denunciados de morte ou envenenamentos pelo contato diários com produtos tóxicos espalhados nas lavouras de grãos.

- A mobilização do trabalho, por sua vez, cumpre um fundamental papel de garantir a realização do valor nas novas áreas de maior inserção no moderno sistema produtor de mercadorias, como é hoje o caso dos cerrados piauienses. Nesse processo, são colocados em movimento os trabalhadores, tanto os expropriados locais quanto os de outras regiões, todos mobilizados forçadamente para tornarem-se trabalhadores do capital. Para o último caso entram em cena os migrantes sulistas revestidos, em princípio, do ideário de vencedores da concorrência no processo de produção agrícola local. Dentro desse grupo, entretanto, a sujeição ao capital só permite a vitória de alguns deles, transformados em grandes produtores agrícolas modernizados; os outros são lançados às fileiras dos perdedores, sobrevivendo com dificuldades sob o controle das empresas comercializadoras de mercadorias agrícolas. Muitos desses últimos tornam-se permanentemente indivíduos mobilizados junto às áreas de fronteiras agrícolas, na esperança de uma inserção plena no moderno sistema produtor de mercadorias, o que dificilmente se realiza.

Como vimos, a modernização tenta de todas as maneiras buscar a uniformidade das formas de organização do sistema produtor de mercadorias, embora ela aconteça se deparando contra si, como um movimento contraditório que é. Neste sentido, é possível afirmar que a imposição de novos processos de modernização ocorre removendo as estruturas de reprodução capitalistas anteriores, mas isso não se faz de uma só vez e totalmente. A história de inserção do Brasil no moderno sistema produtor de mercadorias é sintomática desse processo.

Mesmo considerando hiatos de tempo histórico e de espaço entre a Europa da formação do capitalismo e o Brasil da modernização retardatária, é possível fazer um paralelo dessas duas etapas de formação histórica do sistema produtor de mercadorias. O processo da assim chamada acumulação primitiva que, segundo Marx (1968 [1890]), representou o ponto de partida para a formação das bases do capitalismo mundial, também se manifesta em todo o 
processo de formação do território brasileiro, cuja participação nas esferas de circulação do capital realizou-se, inicialmente, pela via do fornecimento de matérias-primas para o centro do sistema. A não-simultaneidade interna fez com que o país se mantivesse incessantemente convivendo com formas distintas de produção da mercadoria, evidenciando etapas controversas do processo de modernização: espaços cujas bases se ajustam à maior presença do trabalho abstrato, outros, no entanto, inseridos nessa lógica, mas sem que tal percurso se efetive completamente. Amplas áreas do território brasileiro permanecem, todavia, desprovidas em sua totalidade de um capitalismo em que o trabalho assalariado torna-se a única centralidade da produção de valor. $O$ avanço da fronteira agrícola brasileira é uma tentativa de convergência das formas de produção do valor global tendo como centralidade a mercadoria. Uma nova etapa da modernização nessas áreas representou garantias da inserção do capitalismo mediado pelo trabalho e, ao mesmo tempo, a tentativa de eliminação dos vínculos tradicionais construídos a partir de relações sociais entre indivíduos, grupos e comunidades e de todos eles com a natureza. Essas relações não se sustentavam em anos anteriores plenamente pelo intermédio da forma mercadoria. O mundo da racionalização mediada pelo dinheiro se insere nesses lugares mais intensamente pela via da modernização recente.

O processo de modernização, portanto, constitui o cerne das mudanças da sociedade agrária brasileira, pois é ele quem cuidará para que se transforme a estrutura de reprodução do capital pré-existente, ampliando, assim, a acumulação. As condições para a transformação dos espaços de fronteira agrícola em meios de acumulação do capital ocorrem resgatando as formas que permitiram a sua expansão global, nos mesmos moldes da acumulação primitiva, ou seja, convertendo, por um lado, terra pública em terra privada que é lançada no mercado especulativo fundiário e, por outro, camponeses em vendedores de sua própria força de trabalho para o capital.

A reprodução do capital nesses níveis, repetindo os traços fundamentais da acumulação primitiva, é identificada também nos cerrados piauienses. A etapa que se coloca para o processo de modernização atual daquela região registra um processo de privatização avassalador de uma importante parcela das terras devolutas que antes eram aproveitadas pela população local com formas de uso comunitário, atividade que ajudava a manter os grupos 
camponeses locais, como instrumentos de reprodução dos meios de vida. Estas terras, entretanto, agora se transformam em lugar de produção da agricultura capitalista, sob 0 controle de grandes proprietários e/ou arrendatários fundiários. Suprime-se, dessa forma, o direito consuetudinário de uso coletivo da terra passando para a égide do direito privado, conferindo à terra, portanto, a forma mercadoria. Essa transferência de status da terra ocorre mediante anexação direta desse bem por particulares que o retiram do Estado através de grilagem, ou o próprio Estado se encarrega de transferi-la para grupos empresariais privados a preços irrisórios. A história do avanço da fronteira agrícola brasileira é reveladora desses mecanismos de apropriação privada do patrimônio fundiário público, seja pelo consentimento direto do Estado, através da venda de terras em projetos de colonização, ou ele sendo conivente com a ação de falsificadores de registros de terra, muitos dos quais são da própria estrutura do Estado ou de instituições concessoras de registros públicos, como os cartórios.

A usurpação dos meios de vida de uma vasta parcela da população local não somente retirou dela a possibilidade de produzir para a sua subsistência através de seu próprio trabalho, o que garantia o sustento de toda a família, mas o processo de expropriação significou a formação do mercado de trabalho necessário à reprodução do capital. Esse grupo social se converte, dessa maneira, em assalariado, ou em outras formas alternativas de sobrevivência muito mais excludentes. Os antes produtores de seus meios de vida agora se dedicam a procurar quem possa comprar a sua única mercadoria disponibilizada, a própria força de trabalho, ou seja, transformam-se em "vendedores de si mesmos".

A expulsão da população de suas terras, ou daquelas de que se apropriava coletivamente, representou para a reprodução capitalista a possibilidade de transformar os dois instrumentos mais importantes de funcionamento do capital: a terra e o trabalho. Estes foram metamorfoseados em mercadorias para que ocorresse a realização do valor, antes amortecidos para essa forma. A terra, nesse caso, passa de bem de uso comunitário a bem privado, enquanto o camponês passa de possuidor de seus meios de produção em vendedor de seu trabalho em troca de dinheiro. A concretização dessas condições somente será possível aplicando métodos coercitivos, seja para 
dissociarem os produtores de seus meios de vida, seja para forçá-los a se tornarem vendedores de sua força de trabalho.

Cabe ao Estado, nesse sentido, a responsabilidade de disponibilizar as forças repressoras a serviço do capital. Citam-se aqui os inúmeros casos de conflitos envolvendo posseiros e os antigos e novos fazendeiros, como o da Fazenda Pitombeiras, no município de Currais, em que o poder militarizado do Estado foi acionado para remover famílias posseiras em favor dos representantes do agronegócio. O caso mais emblemático, no entanto, aconteceu com a instalação nos cerrados piauienses da empresa indiana Anna Purna. Este grande grupo econômico produtor de alimentos orgânicos, ao adquirir naquela área uma grande extensão de terra, deparou-se também com a presença de posseiros. Tal empresa exigiu, então, não somente a remoção de todas as famílias camponesas habitantes do local, mas também determinou coercitivamente a transferência dos restos mortais sepultados no local, tudo isso com anuência do Estado.

O Estado representa, desse modo, um alicerce fundamental cujo suporte em vários níveis permite que o capital consiga se reproduzir. A história da modernização capitalista brasileira novamente está repleta de situações que apontam nessa direção. Para nos determos apenas no nosso universo de pesquisa (os cerrados piauienses e, em geral, os nordestinos), é o aparato do Estado que tornará possível os repasses das terras dos gerais aos grupos empresariais da agricultura moderna. Disponibilizou ele a estes agentes grandes parcelas de terras devolutas, muitas das quais transformadas em propriedade pública que posteriormente foram privatizadas, seja através de doação ou comercializadas por preços reduzidos, mas com a expectativa de renda futura garantida. A privatização do patrimônio fundiário muitas vezes ocorreu de maneira fraudulenta: as mesmas terras que, pouco tempo depois, foram ou são colocadas pelos especuladores no mercado imobiliário, sendo dessa forma valorizadas, deixaram em detrimento as populações que faziam usufruto delas para sua subsistência. Esse mesmo Estado assegura as condições de instalação das empresas vencedoras na região, adaptando as formas jurídicas para favorecer benesses fiscais a tais grupos econômicos.

O mesmo Estado que possibilitou tornar a terra mercadoria objetivando atrair a produção, depara-se agora, contraditoriamente, com custos adicionais 
decorrentes dos problemas gerados pela atual modernização. Ele é obrigado a absorver os elevados encargos produzidos pelo acréscimo de excluídos que passam a habitar o urbano. Ao tornar-se expropriada, essa população deslocase para o urbano com chances muito reduzidas de encontrar qualquer tipo de ocupação nas novas áreas de moradias, o que amplia as suas necessidades de recorrer aos debilitados sistemas de proteção estatal.

Acrescenta-se também o aumento das despesas públicas para amenizar os custos ecológicos. A grande alteração do bioma de cerrado que ocorre recentemente por conta do desmatamento para a produção de commodities agrícolas, com destaque para a soja, sustenta essa assertiva. Além dos recursos financeiros estatais destinados à reversão dos estragos deixados pelas formas modernas de produção agrícola, é necessário incluir o preço humano que essa e as próximas gerações pagarão pelo "colapso" do meio natural que já é sentido atualmente ou se anuncia com mais vigor para os próximos anos.

Finalmente, o Estado também se coloca como responsável pela construção dos agregados de infra-estrutura, os quais visam muito mais garantir a formação do capital através da produção e da circulação das mercadorias destinadas aos grandes mercados consumidores internos e externos do que a atender verdadeiramente as demandas locais.

Diante do exposto cabe questionar se a nova estrutura de organização sócio-econômica em emergência nos cerrados piauienses corresponde verdadeiramente a formas de desenvolvimento como querem demonstrar os representantes do agronegócio, ou se se configura como manifestações da crise da modernização, nesse caso, instituindo formas de exclusão mais explícitas. Tentamos demonstrar na pesquisa que a segunda opção é a que se confirma. 


\section{BIBLIOGRAFIA}

AB'SÁBER, Aziz Nacib. Os Domínios de Natureza no Brasil: Potencialidades Paisagísticas. São Paulo: Ateliê Editorial, 2003.

ASSOCIAÇÃO Brasileira das Indústrias de Óleos Vegetais (ABIOVE). Brasil: Exportação do Complexo Soja. Disponível em: http://www.abiove.com.br

ABRAMOVAY, Ricardo. "Agricultura Familiar e Desenvolvimento Territorial" In Reforma Agrária - ABRA, vol. 29, n 1, jan-ago, 1999, pp. 50-67.

ABREU, João Capistrano de. Capítulos de História Colonial (1500-1800). Rio de Janeiro: Livraria Briguet, $5^{\mathrm{a}}$ ed, 1969.

ALVES, Vicente Eudes Lemos. "Modernização Agropecuária, Ruptura e Permanência do Modo de Vida Camponês nos Cerrados Piauienses" In Boletim Paulista de Geografia, $\mathrm{n}^{\circ}$ 77, São Paulo: Associação dos Geógrafos Brasileiros, 2001, pp. 07-28.

ALVES, Vicente Eudes Lemos. Formação Territorial Sul Piauiense: Modernização Agropecuária e Resistência Camponesa. São Paulo: Universidade de São Paulo, Faculdade de Filosofia, Letras e Ciências Humanas, Departamento de Geografia, Dissertação de Mestrado, 2000.

ANDREAZZA, Maria Luiza \& NADALIN, Sérgio Odilon. "O Cenário da Colonização no Brasil Meridional e a Família Imigrante". In Revista Brasileira de Estudos de População, v. 11, n 1, jan-jun, 1994, pp. 61-87.

ANTUNES, Ricardo. Adeus ao Trabalho? Ensaio sobre as Metamorfoses e a Centralidade do Mundo do Trabalho. São Paulo/Campinas: Cortez/Ed. da Unicamp, 1995.

ANTUNES, Ricardo (org.). A Dialética do Trabalho. São Paulo: Expressão Popular, 2004.

ANUÁRIO Exame As 400 Maiores do Agronegócio. São Paulo: Ed. Abril, agosto, 2006.

ARANTES, Paulo E. Sentimento da Dialética na Experiência Intelectual Brasileira. Rio de Janeiro: Paz e Terra, 1992. 
ARAÚJO, Márcia Regina Soares. Expansão da Fronteira Agrícola nos Cerrados Piauienses, (des)Territorialização e os Desafios para o Desenvolvimento Territorial: o Caso do Município de Bom Jesus. Teresina: Universidade Federal do Piauí/PRODEMA/TROPEN, Dissertação de Mestrado, 2006.

ARAÚJO, Tânia Bacelar de. "Nordeste, Nordestes: que Nordeste?" In AFFONSO, R.B.A. \& SILVA, P.L.B. (orgs.). Federalismo no Brasil: Desigualdades Regionais e Desenvolvimento. São Paulo: Fundap/Editora da Unesp, 1995, pp. 125-156.

ARAÚJO, Tânia Bacelar de. Ensaios sobre o Desenvolvimento Brasileiro: Heranças e Urgências. Rio de Janeiro: Revan/Fase, 2000.

ARROYO, Maria Mônica. Território Nacional e Mercado Externo: uma Leitura do Brasil na Virada do Século XX. São Paulo: Universidade de São Paulo, Faculdade de Filosofia, Letras e Ciências Humanas, Departamento de Geografia, Tese de Doutorado, 2001.

ASSELIN, Victor. Grilagem, Corrupção e Violência em Terras do Carajás. Petrópolis: Vozes, 1982.

BANDEIRA, Willian J. Os Programas e Projetos Governamentais e seus Efeitos sobre a Estrutura Agrária Piauiense no Pós-70. Campinas: Universidade Estadual de Campinas, Instituto de Economia, Tese de Doutorado, 1993.

BASA/IPEA/ANPEC. Projeto de Contribuição ao Desenvolvimento dos Principais Arranjos Produtivos Locais Potenciais dos Estados da Amazônia: Estado do Maranhão. dezembro, 2002 (texto mimeo).

BECKER, Bertha. "A Mobilidade do Trabalho: Um Novo Marco Teórico". In Ciência Hoje, vol. 3, no 17, mar-abr, 1985, pp. 54-56.

BECKER, Olga M. S. "Mobilidade Espacial da População: Conceitos, Tipologia, Contextos". In CASTRO, I. E. de; GOMES, P. C. da \& CORREAA, R. L. (coords.). Explorações Geográficas: Percursos no Fim do Século. Rio de Janeiro: Bertrand Brasil, 1997, pp. 319-367.

BELIK, Walter. Muito Além da Fronteira: Mudanças nas Formas de Coordenação da Cadeia Agroalimentar no Brasil. Campinas: Unicamp-IE, 2001.

BERTRAND, Jean-Pierre (et al.). O Mundo da Soja. São Paulo: Hucitec/Edusp, 1987. 
BRANDÃO, Antônio Salazar Pessoa (et al.). "Crescimento Agrícola no Período 1999-2004, Explosão da Área Plantada com Soja e Meio Ambiente no Brasil". In IPEA (Texto para Discussão), n 1062, Rio de Janeiro, janeiro, 2005, pp.1-21.

BRAUDEL, Fernand. A Dinâmica do Capitalismo. Lisboa: Editorial Teorema, $3^{\text {a }}$ ed, 1989.

BRUM, Argemiro J. A Comercialização de Grãos: o Caso da Soja. ljuí: FIDENE, 1983.

BRUM, Argemiro J. Modernização da Agricultura: Trigo e Soja. Petrópolis/ljuí: Vozes/FIDENE, 1988.

BUNGE ALIMENTOS S.A. Centro de Memória Bunge: Guia Eletrônico do Centro de Memória. Bunge Alimentos S.A., Disponível em: http://www.fundacaobunge.org.br

BUNGE ALIMENTOS S.A. Unidades Industriais e Áreas de Atuação. Bunge Alimentos S.A., Disponivel em: http://www.bunge.com.br

CAMPOS, Nazareno José. Terras de Uso Comum no Brasil: Um Estudo de suas diferentes Formas. São Paulo: Universidade de São Paulo, Faculdade de Filosofia, Letras e Ciências Humanas, Departamento de Geografia, Tese de Doutorado, 2000.

CARNEIRO, Ricardo; SAMPAIO, Y. \& GOMES, G. M. "Os Programas de Desenvolvimento Rural: Região Nordeste". In PIMES (SUDENE) Desigualdades Regionais no Desenvolvimento Brasileiro, v.3, Recife: SUDENE, 1984, pp.87-245.

CASTILLO, Ricardo. "Transporte e Logística de Granes Sólidos Agrícolas: Componentes Estruturais do Novo Sistema de Movimentos do Território Brasileiro". Campinas: Unicamp-IG, s/d, pp.1-20.

CASTRO, Ana Célia. Localização e Identificação das Empresas Processadoras de Soja, suas Áreas de Influência, Preços e Custos de Transporte Relacionados. Rio de Janeiro: CPDA/UFRJ, s/d.

CASTRO, Edna M. Ramos \& HÉBETTE, Jean (orgs.). "Na Trilha dos Grandes Projetos: Modernização e Conflito na Amazônia". In Cadernos do NAEA (10), Belém, 1989, pp. 71-97. 
CENTRO Scalabriano de Estudos Migratórios (CSEM). Balsas: Alteridade, Desencontro e Esperança. Brasília: CSEM Editora, 2000.

CHAYANOV, Alexander V. La Organización de la Unidad Económica Campesina. Buenos Aires: Ediciones Nueva Visión, 1974.

CHESNAIS, François. A Mundialização do Capital. São Paulo: Xamã, 1996.

COMPANHIA Nacional de Abastecimento (CONAB). Série Histórica de Produção, Produtividade e Área Plantada - Safras 1976/77 a 2005/06. Disponível em: http://www.conab.gov.br

CORREGEDORIA Geral da Justiça do Estado do Piauí. Correição (Fiscalização) Extraordinária nos Cartórios da Comarca de Santa Filomena. Teresina: abril, 2001 (texto mimeo).

COSTA, Luis F.C.; MOREIRA, Roberto J. \& BRUNO, Regina (orgs.). Mundo Rural e Tempo Presente. Rio de Janeiro: Mauad, 1999.

COMISSÃO Pastoral da Terra (CPT). Conflitos de Terra por Estado - Brasil, 1997-2003. Disponível em: http://www.cptnac.com.br

DELGADO, Guilherme C. Capital Financeiro e Agricultura no Brasil. Campinas: Unicamp-ICOM, 1982.

DIETZ, Circe Inês. Espaço, Tempo e Técnica: as Transformações Espaciais na Microrregião Geográfica de Santa Rosa - RS. Santa Maria: Universidade Federal de Santa Maria, Monografia de Graduação em Geografia, 2006.

DINIZ, José A. "Modernização e Conflito na Fronteira Ocidental do Nordeste". In Revista Geonordeste, ano I, n 1, Aracaju, 1984, pp. 12-20.

DINIZ, José A.F. Geografia da Agricultura. São Paulo: Difel, 1984.

DROS, Jan M. Administrando os Avanços da Produção de Soja. Dois Cenários da Expansão do Cultivo de Soja na América do Sul. Amsterdã: AIDEnvironment (WWF), junho/2004. Disponível em: http//www.wwf.org

DUARTE, Laura Maria G. \& THEODORO, Suzi Huff (orgs.). Dilemas do Cerrado: entre o Ecologicamente (in)correto e o Socialmente (in)justo. Rio de Janeiro: Garamond, 2002.

ELIAS, Denise. Globalização e Agricultura: A Região de Ribeirão Preto - SP. São Paulo: Edusp, 2003.

ENGELS, Friedrich. A Situação da Classe Trabalhadora na Inglaterra. São Paulo: Global, 1986 [1845]. 
ESPINDOLA, Carlos José. As Agroindústrias no Brasil: o Caso da Sadia. Chapecó: Grifos, 1999.

ETGES, Virginia E. Geografia Agrária: A Contribuição de Leo Waibel. Santa Cruz do Sul: EDUNISC, 2000.

FREDERICO, Samuel. Sistemas de Movimento no Território Brasileiro: os Novos Circuitos Espaciais Produtivos da Soja. Campinas: Universidade Estadual de Campinas, Instituto de Geociências, Dissertação de Mestrado, 2004.

GASQUES, José Garcia \& CONCEIÇÃO, Júnia Cristina P. R. da. "Financiamento da Agricultura - Experiências e Propostas". In GASQUES, J.G. \& CONCEIÇÃO, J.C.P.R. da (orgs.). Transformações da Agricultura e Políticas Públicas. Brasília: IPEA, 2001, pp. 96-155.

GASQUES, José Garcia (et al.). "Competitividade de Grãos e de Cadeias Selecionadas do Agribusiness". In Texto para Discussão (IPEA), n 538 , Brasília, janeiro/1998, pp.7-18.

GAUDEMAR, Jean-Paul de. La Mobilisation Générale. Paris: Éditions du Champ Urbain, 1979.

GAUDEMAR, Jean-Paul de. Mobilidade do Trabalho e Acumulação do Capital. Lisboa: Editorial Estampa, 1977.

GIORDANO, Samuel Ribeiro. Competitividade Regional e Globalização. São Paulo: Universidade de São Paulo, Faculdade de Filosofia, Letras e Ciências Humanas, Departamento de Geografia, Tese de Doutorado, 1999.

GOMES, Gustavo M. Velhas Secas em Novos Sertões: Continuidade e Mudanças na Economia do Semi-árido e dos Cerrados Nordestinos. Brasília: IPEA, 2001.

GRAZIANO DA SILVA, José. A Nova Dinâmica da Agricultura Brasileira. Campinas: Unicamp-IE, 1996.

GRUPO Krisis. Manifesto Contra o Trabalho. São Paulo: Conrad Editora do Brasil, 2003.

GUIMARÃES NETO, Leonardo. "Desigualdades e Políticas Regionais no Brasil: Caminhos e Descaminhos". In Planejamento e Políticas Públicas, $\mathrm{n}^{\circ} 15$, Rio de Janeiro, junho, 1997, pp.43-95. 
GUIMARÃES NETO, Leonardo. "Desigualdades Regionais e Federalismo". In AFFONSO, R.B.A. \& SILVA, P.L.B. Federalismo no Brasil: Desigualdades Regionais e Desenvolvimento. São Paulo: Fundap/Ed Unesp, 1995, pp. 13-59.

GUIMARÃES NETO, Leonardo. Introdução à Formação Econômica do Nordeste. Recife: FUNDAJ/Editora Massangana, 1989.

HAESBAERT, Rogério. "A Noção de Rede Regional: Reflexões a partir da Migração 'Gaúcha' no Brasil”. In Território, ano III, n 4, Rio de Janeiro, jan-jun, 1998, pp. 55-71.

HAESBAERT, Rogério. "Desterritorialização: entre as Redes e os Conglomerados de Exclusão". In CASTRO, I.E.; GOMES, P.C.C. \& CORREAA, R.L (orgs.). Geografia: Conceitos e Temas. Rio de Janeiro: Bertrand Brasil, 1995, pp. 165-205.

HAESBAERT, Rogério. "Gaúchos" no "Novo" Nordeste: entre a Globalização Econômica e a Reinvenção das Identidades Territoriais. In CASTRO, Iná E.; GOMES, Paulo C.C. \& CORRÊA, Roberto L. (orgs.). Brasil: Questões Atuais da Reorganização do Território. Rio de Janeiro: Bertrand Brasil, 1996, pp. 367-415.

HAESBAERT, Rogério. "Região e Redes Transfronteiriças em Áreas de Migração Brasileira nos Vizinhos do Mercosul". In STROHAECKER, Tânia M. (et al.). Fronteiras e Espaço Global. Porto Alegre: Associação dos Geógrafos Brasileiros, 1998, pp.59-68.

HAESBAERT, Rogério. Des-territorialização e Identidade: a Rede Gaúcha no Nordeste. Niterói: EdUFF, 1997.

HÉBETTE, Jean. Cruzando a Fronteira: 30 anos de Estudo do Campesinato na Amazônia. Belém: EdUFPA, 2004.

HEIDEMANN, Heinz Dieter. "A Volta do Pau-de-Arara como Veículo de Homogeneização do Mercado Nacional”. In Geonordeste, ano I, no 1 , Aracaju, 1984, pp. 47-50.

HELFAND, S.M. \& RESENDE, G.C. A Agricultura Brasileira nos anos 1990: o Impacto das Reformas de Políticas. In GASQUES, J.G. \& CONCEIÇÃO, J.C.P.R. da (orgs.). Transformações da Agricultura e Políticas Públicas. Brasília: IPEA, 2001, pp. 247-301. 
INSTITUTO Brasileiro de Geografia e Estatística (IBGE). Cadastro Central de Empresas. Disponível em: http://www.sidra.ibge.gov.br

INSTITUTO Brasileiro de Geografia e Estatística (IBGE). Censo Demográfico 2000. Rio de Janeiro, 2000.

INSTITUTO Brasileiro de Geografia e Estatística (IBGE). Produção Agrícola Municipal 2000. Disponível em: http://www.ibge.gov.br

INSTITUTO Brasileiro de Geografia e Estatística (IBGE). Produção Agrícola Municipal 2001. Disponível em: http://www.ibge.gov.br

INSTITUTO Brasileiro de Geografia e Estatística (IBGE). Produção Agrícola Municipal 2002. Disponível em: http://www.ibge.gov.br

INSTITUTO Brasileiro de Geografia e Estatística (IBGE). Produção Agrícola Municipal 2003. Disponível em: http://www.ibge.gov.br

INSTITUTO Brasileiro de Geografia e Estatística (IBGE). Produção Agrícola Municipal 2004. Disponível em: http://www.ibge.gov.br

INSTITUTO Brasileiro de Geografia e Estatística (IBGE). Produção Agrícola Municipal 2005. Disponível em: http://www.ibge.gov.br

INSTITUTO Nacional de Colonização e Reforma Agrária (INCRA). Estatísticas Cadastrais Segundo a Categoria de Imóvel Rural. Brasília, 2003.

IOKOI, Zilda Grícoli. Igreja e Camponeses: Teologia da Libertação e Movimentos Sociais no Campo - Brasil e Peru, 1964-1986. São Paulo: Hucitec/Fapesp, 1996.

KURZ, Robert. "As Leituras de Marx no Século XXI". In KURZ, Robert. Ler Marx. Os Textos mais Importantes de Marx para o Século XXI (tradução: Grupo do Jornal Crítica Radical), Fortaleza, 2002, (texto mimeo).

KURZ, Robert. "As Luzes do Mercado se Apagam: as Falsas Promessas do Neoliberalismo ao Término de um Século em Crise". In Estudos Avançados, vol. 7, no 18, São Paulo, mai-ago, 1993, pp. 07-41.

KURZ, Robert. O Colapso da Modernização: da Derrocada do Socialismo de Caserna à Crise da Economia Mundial. São Paulo: Paz e Terra, 1992.

KURZ, Robert. Os Últimos Combates. Petrópolis: Vozes, 1998.

LANDO, Aldair Marli (et al.). RS: Imigração \& Colonização. Porto Alegre: Mercado Aberto, 1980. 
MAGALHÃES, Luis C. G. de. "Competitividade de Grãos e de Cadeias Selecionadas do Agribusiness: Soja". In Texto para discussão (IPEA), $\mathrm{n}^{\circ}$ 538, Brasília, 1998, pp.95-141.

MARTINE, George. "A Evolução Espacial da População Brasileira". In AFFONSO, R.B.A. \& SILVA, P.L.B. Federalismo no Brasil: Desigualdades Regionais e Desenvolvimento. São Paulo: Fundap/Ed Unesp, 1995, pp. 61-91.

MARTINE, George. "Estado, Economia e Mobilidade Geográfica: Retrospectiva e Perspectivas para o Fim do Século". In Revista Brasileira de Estudos de População, v. 11, no 1, jan-jun, 1994, pp. 41-60.

MARTINE, George. "Fases e Faces da Modernização Agrícola Brasileira". In Planejamento e Políticas Públicas, $\mathrm{n}^{\circ}$ 3, Rio de Janeiro, junho, 1990, pp.03-44.

MARTINELLI JR., Orlando. A Globalização e a Indústria Alimentar: um Estudo a partir das Grandes Empresas. São Paulo: Fapesp, 1999.

MARTINS, Agenor de Sousa (et al.). Piauí: Evolução, Realidade e Desenvolvimento. Teresina: Fundação Cepro, $2^{\mathrm{a}}$ ed, 2002.

MARTINS, José de Souza. "O Problema das Migrações no Limiar do Terceiro Milênio". In SERVIÇO Pastoral dos Migrantes (et al.). O Fenômeno Migratório no Limiar do $3^{\circ}$. Milênio: Desafios Pastorais. Petrópolis: Vozes, 1998, pp. 19-34.

MARTINS, José de Souza. Expropriação e Violência: a Questão Política no Campo. São Paulo: Hucitec, 1982.

MARTINS, José de Souza. Fronteira: a Degradação do Outro nos Confins do Humano. São Paulo: Hucitec, 1997.

MARTINS, José de Souza. O Cativeiro da Terra. São Paulo: LECH, 1981.

MARTINS, Sérgio M.M. A Cidade 'Sem Infância' no Universo Pioneiro de Chapadão do Sul (MS). São Paulo: Universidade de São Paulo, Faculdade de Filosofia, Letras e Ciências Humanas, Departamento de Geografia, Dissertação de Mestrado, 1993.

MARX, Karl. O Capital (Crítica da Economia Política). O Processo de Produção Capitalista. (Livro 1, Vol. 2). Rio de Janeiro: Editora Civilização Brasileira S.A., 1968 [1890]. 
MARX, Karl O Capital (Crítica da Economia Política). O Processo Global de Produção Capitalista. (Livro 3, Vol. 6). Rio de Janeiro: Editora Civilização Brasileira S.A., 1968 [1894].

MATOS, Carlos. "Redes, Nodos e Cidades: Transformação da Metrópole Latino-Americana". In Ribeiro, L. C. (org.). Metrópoles: entre a Coesão e a Fragmentação, a Cooperação e o Conflito. São Paulo/Rio de Janeiro: Perseu Abramo/Fase, 2004, pp. 157- 192.

MELO, Caroline M. \& MOTA, Luciene de A. A Dinâmica Econômica e Cultural na Cidade de Balsas e em sua Região de Influência (1980-2000). Imperatriz: Universidade Estadual do Maranhão/CESI, Monografia de Graduação em Geografia, 2004.

MESQUITA, Arlan Mendes \& ALENCAR JR., José Sydrião. Perfil Econômico do Maranhão. Fortaleza: Banco do Nordeste, 2002.

MINISTÉRIO do Trabalho e Emprego. Cadastro Geral de Empregados e Desempregados. Perfil do Município. Disponível em: http://www.perfildomunicipio.caged.gov.br

MINISTÉRIO do Trabalho e Emprego (Delegacia Regional do Trabalho Piaui). Relatório de Fiscalização (Fazenda Vista Verde - Manoel Emídio). Teresina, novembro, 2005, (texto mimeo).

MINISTÉRIO do Trabalho e Emprego (Delegacia Regional do Trabalho Piauí). Relatório de Fiscalização (Fazenda Cosmos - Ribeiro Gonçalves/PI). Teresina, julho, 2004, (texto mimeo).

MINISTÉRIO do Trabalho e Emprego (Delegacia Regional do Trabalho Piauí). Relatório de Fiscalização (Empresas dos Cerrados Piauienses Uruçui, Ribeiro Gonçalves e Baixa Grande do Ribeiro). Teresina, junho, 2003, (texto mimeo).

MIZUSAKI, Márcia Yukari. Monopolização do Território e Reestruturação Produtiva na Avicultura em Mato Grosso. São Paulo: Universidade de São Paulo, Faculdade de Filosofia, Letras e Ciências Humanas, Departamento de Geografia, Tese de Doutorado, 2003.

MONBEIG, Pierre. Pioneiros e Fazendeiros de São Paulo. São Paulo: Hucitec/Polis, 1984. 
MONTEIRO, Maria do Socorro L. Ocupação do Cerrado Piauiense: Estratégia Empresarial e Especulação Fundiária. Campinas: Universidade Estadual de Campinas, Instituto de Economia, Tese de Doutorado, 2002.

MORAES, Maria Dione de C. Memórias de um Sertão Desencantado; Modernização Agrícola, Narrativas e Atores Sociais nos Cerrados do Sudoeste Piauiense. Campinas: Universidade Estadual de Campinas, Instituto de Filosofia e Ciências Humanas, Tese de Doutorado, 2000.

MOTT, Luiz R.B. Piauí Colonial: População, Economia e Sociedade. Teresina: Projeto Petrôneo Portela, 1985.

MOURA, Clóvis. "O Arcaico e o Moderno na Construção da Atual Sociedade Brasileira". In ASSIS, Brasil (et al.). O Brasil no Limiar do Novo Milênio. Teresina: Fundação Banco do Brasil/Academia Piauiense de Letras, 2001, pp. 59-86.

MÜLLER, Geraldo. Modernização Agroindustrial e Modernização Agrária. São Paulo, Hucitec/Educ, 1989.

MUMFORD, Lewis. A Cidade na História. Belo Horizonte: Itatiaia, 1965.

NONATO, Rita de Cássia. Crise da Federação e Federalismo Corporativo: Propostas de Criação de Novos Estados no Front Agrícola Brasileiro. Campinas: Universidade Estadual de Campinas, Instituto de Geociências, Dissertação de Mestrado, 2005.

OJIMA, Andréia Leda Ramos O. "Perfil da Logística de Transporte de Soja no Brasil”. In Informações Econômicas, v. 36, n 1, São Paulo, janeiro, 2006, pp. 17-25.

OLIVEIRA, Ariovaldo U. de. "A Geografia Agrária e as Transformações Territoriais Recentes no Campo Brasileiro". In CARLOS, A. F. A. (org.). Novos Caminhos da Geografia. São Paulo: Contexto, 2002, pp.63-110.

OLIVEIRA, Ariovaldo U. de. "BR - 163 Cuiabá - Santarém: Geopolítica, Grilagem, Violência e Mundialização". In TORRES, Maurício (org.). Amazônia Revelada: os Descaminhos ao Longo da BR - 163. Brasília: CNPq, 2005, pp. 60-169. 
OLIVEIRA, Ariovaldo U. de. "Território e Migração: uma Discussão Conceitual na Geografia" (Conferência). In Simpósio Internacional "Migração: Nação, Lugar e Dinâmicas Territoriais" (UGI), São Paulo: Universidade de São Paulo, Faculdade de Filosofia, Letras e Ciências Humanas, Departamento de Geografia, abril, 1999, (texto mimeo).

OLIVEIRA, Ariovaldo Umbelino de. "Os Mitos sobre o Agronegócio no Brasil". In Revista Sem Terra, ano VI, $\mathrm{n}^{\circ}$ 24, mai-jun, 2004. Disponível em: http://www.mst.org.br

OLIVEIRA, C.A. de (org.). O Mundo do Trabalho - Crise e Mudança no Final do Século. Campinas: Cesit-Scritta, 1994.

OLIVEIRA, Francisco. Elegia para uma Re(li)gião: Sudene, Nordeste. Planejamento e Conflitos de Classes. Rio de Janeiro: Paz e Terra, 1981.

OLIVEIRA, Francisco de. A Economia da Dependência Imperfeita. Rio de Janeiro: Graal, 1977.

OLIVEIRA, Naia \& BARCELOS, Tânia de Medeiros. "Fronteiras no Mundo Globalizado: o Fim dos Limites?" In Indicadores Econômicos FEE, v. 27, n² 2, Porto Alegre, setembro, 1999, pp. 153-162.

ORTIZ, Renato. Mundialização e Cultura. São Paulo: Brasiliense, 1994.

PAIVA, Odair da Cruz. Caminhos Cruzados: a Migração para São Paulo e os Dilemas da Construção do Brasil Moderno nos anos 1930/50. São Paulo: Universidade de São Paulo, Faculdade de Filosofia, Letras e Ciências Humanas, Departamento de História, Tese de Doutorado, 2000.

PAULA ANDRADE, Maristela de. Os Gaúchos Descobrem o Brasil: os Pequenos Produtores Agrícolas do Sertão Maranhense Frente à Implantação de Projetos Agropecuários. São Paulo: Universidade de São Paulo, Faculdade de Filosofia, Letras e Ciências Humanas, Dissertação de Mestrado, 1982.

PAULA ANDRADE, Maristela de (et al.). Carajás: Desenvolvimento ou Destruição? São Luís: CPT, $1^{\text {a }}$ ed, maio, 1995, pp.242-274.

PEDROSA, Luis Antonio C. A Questão Agrária no Maranhão. São Luís, s/d. (texto mimeo).

PELIANO, José C. Acumulação do Trabalho e Mobilidade do Capital. Brasília: Editora UNB, 1990. 
PEREIRA DÁLENCASTRO, J. M. "Memória Chronológica, Histórica e Corografica da Província do Piauhy". In Revista do Instituto Histórico e Geográfico Brasileiro, Tomo XX, $1^{\circ}$ trimestre, 1857, p. 5.

PINTO, Maria Novaes (org.). Cerrado: Caracterização, Ocupação e Perspectivas. Brasília: Editora UNB, 1990.

POLANYI, Karl. A Grande Transformação: as Origens da Nossa Época. Rio de Janeiro: Campus, $2^{\mathrm{a}}$ ed, 2000.

PORTO GONÇALVES, Carlos W. \& LACERDA, Andressa. "Conflitos do Cerrado". In Anais Seminário Internacional Bioma Cerrado "Grito dos Povos Contra a Destruição do Cerrado", Balsas, 2004, pp. 27-34.

PÓVOA-NETO, Hélion. "Migrações Internas e Mobilidade do Trabalho no Brasil Atual. Novos Desafios". In Experimental, ano I, nº 2, março, 1997, pp.1123.

PÓVOA-NETO, Hélion. 'Migrantes, Garimpeiros e seu 'Lugar' no Território Nacional: Itinerância e Mobilidade Espacial do Trabalho". In GeoUERJ: Revista do Departamento de Geografia, v.1, $\mathrm{n}^{\circ}$ 2, Rio de Janeiro, 1997, pp.43-49.

PRADO JR., Caio. Formação do Brasil Contemporâneo. São Paulo: Brasiliense, 1965.

PRADO JR., Caio. História Econômica do Brasil. São Paulo: Brasiliense, 18a ed, 1985.

RAVENSTEIN, E.G. "As Leis da Migração". In MOURA, A. de (coord.). Migração Interna (textos selecionados). Fortaleza: BNB/ETENE, 1980, pp.24-88.

ROCHE, Jean. A Colonização Alemã e o Rio Grande do Sul. Porto Alegre: Editora Globo, 1969.

RUCKERT, Aldomar. Metamorfoses do Território: Agricultura de Trigo/Soja no Planalto Médio Rio-grandense - 1930-1990. Porto Alegre: Editora da UFRGS, 2003.

SALES, Marta C.L. "Estudo da Degradação Ambiental em Gilbués - PI: Reavaliando o 'Núcleo de Desertificação'. São Paulo: Universidade de São Paulo, Faculdade de Filosofia, Letras e Ciências Humanas, Departamento de Geografia, Dissertação de Mestrado, 1997. 
SALES, Teresa. "Novos Fluxos Migratórios da População Brasileira". In Revista de Estudos de População, vol. 8 (1-2), jan-dez, 1991, pp.19-99.

SALIM, Celso A. "Migração: O Fato e a Controvérsia Teórica". In Anais VIII Encontro Nacional de Estudos Populacionais, vol. 3, São Paulo: ABEP, 1992, pp. 119-144.

SANTOS, Conceição M. S. \& SILVA, Maria M. M. Impactos Sócio-Econômicos e Culturais Gerados na Cidade de Bom Jesus após a Entrada de Imigrantes Sulistas. Bom Jesus, s/d. (texto mimeo).

SANTOS, José V. T. dos. Matuchos: Exclusão e Luta - do Sul para a Amazônia. Petrópolis: Vozes, 1993.

SANTOS, Milton. A Natureza do Espaço. Técnica e Tempo. Razão e Emoção. São Paulo: Hucitec, 1996.

SANTOS, Milton. A Urbanização Brasileira. São Paulo: Hucitec, 1993.

SANTOS, Rosselvelt José. As Humanidades do Cerrado na Dialética da Festa e do Espetáculo. São Paulo: Universidade de São Paulo, Faculdade de Filosofia, Letras e Ciências Humanas, Departamento de Geografia, Tese de Doutorado, 1998.

SCHAEFER, José R. As Migrações Rurais e Implicações Pastorais: um Estudo das Migrações Campo-Campo do Sul do País em Direção ao Norte de Mato Grosso. São Paulo: Edições Loyola, 1985.

SEABRA, Odette Carvalho de Lima. "Territórios do Uso: Cotidiano e Modo de Vida". In Cidades: Revista Científica/Grupo de Estudos Urbanos, vol.1, n², Presidente Prudente, 2004, pp.181-206.

SECRETARIA de Comércio Exterior (SECEX). Exportação Brasileira. Brasília, 2005.

SUPERINTENDÊNCIA de Estudos Econômicos e Sociais da Bahia (SEI). Mudanças Sóciodemográficas Recentes: Região Oeste. Salvador, 2000.

SUPERINTENDÊNCIA de Estudos Econômicos e Sociais da Bahia (SEI). Consulta ao Banco de Dados. Salvador. Disponível em: http://www.sei.ba.gov.br

SILVA, Carlos Alberto F. da. Grupo André Maggi: Corporação e Rede em Áreas de Fronteira. Cuiabá: Entrelinhas, 2003.

SINGER, Paul. Economia Política e Urbanização. São Paulo: Brasiliense, 1987. 
SIQUEIRA, Tagore Villarim de. "O Ciclo da Soja: o Desempenho da Cultura da Soja entre 1961 e 2003". In BNDES Setorial, n² 20, Rio de Janeiro, setembro, 2004, pp. 127-222.

SPIX \& MARTIUS. Viagem pelo Brasil (1817-1820). São Paulo: Melhoramentos, 1938.

TAVARES, Maria da Conceição. Ciclo e Crise: O Movimento Recente da Industrialização Brasileira. Campinas: Unicamp/IE, 1998.

THOMPSON, E.P. Costumes em Comum: Estudos sobre a Cultura Popular Tradicional. São Paulo: Companhia das Letras, 1998.

TOLEDO, Carlos de A. A Mobilidade do Trabalho nas Lavras Baianas. São Paulo: Universidade de São Paulo, Faculdade de Filosofia, Letras e Ciências Humanas, Departamento de Geografia, Dissertação de Mestrado, 2001.

VAINER, Carlos B. "A Violência como Fator Migratório: Silêncios Teóricos e Evidências Históricas". In Travessia (Centro de Estudos Migratórios), ano IX, n 25, São Paulo, mai-ago, 1996, pp.05-10.

VAINER, Carlos B. "Migração e Mobilidade na Crise Contemporânea da Modernização" (Conferência). In Simpósio Internacional "Migração: Nação, Lugar e Dinâmicas Territoriais" (UGI). São Paulo: Universidade de São Paulo, Faculdade de Filosofia, Letras e Ciências Humanas, Departamento de Geografia, abril, 1999, (texto mimeo).

VELASCO, Miriam M. Descentralização e Política Urbana em Municípios de Porte Médio: os casos de Alagoinhas e Barreiras na Bahia. São Paulo: Universidade de São Paulo, Faculdade de Arquitetura e Urbanismo, Tese de Doutorado, 2004.

VELHO, Otávio G. Frentes de Expansão e Estrutura Agrária: um Estudo do Processo de Penetração numa Área da Transamazônica. Rio de Janeiro: Editora Dedalus, 1972.

WAIBEL, Léo. Capítulos de Geografia Tropical e do Brasil. Rio de Janeiro: IBGE, $2^{\mathrm{a}}$ ed, 1979. 


\section{Artigos de Jornais e Revistas}

BUNGE ALIMENTOS S.A. - Bunge Planeta: Unidade de Uruçuí está funcionado. Bunge Alimentos S.A., ano 01, n 08, ago. de 2003.

BUNGE ALIMENTOS S.A. - Bunge Planeta: um prêmio à preservação da vida e da natureza. Bunge Alimentos S.A., ano 03, n 32, ago. de 2005.

BUNGE ALIMENTOS S.A. - Bunge Planeta: inaugurado centro de divulgação ambiental. Bunge Alimentos S.A., ano 04, n 37, jan. de 2006.

DIÁRIO DO POVO - Começou a saga gaúcha nos cerrados do Piauí. Diário do Povo, Agrobusiness, 30/04/1999, p. 1-4.

FOLHA DE S.PAULO - Soja aumenta espaço no cerrado do Piauí. Folha de S.Paulo, Agrofolha, 23/10/1996, 3.

FOLHA DE S.PAULO - Cerrado do Piauí está sendo devastado por agricultores. Folha de S.Paulo, Brasil, 24/12/2000, A 11.

FOLHA DE S.PAULO - 10 mil trabalhadores vivem em condição de escravidão. Folha de S.Paulo, Brasil, 06/10/2002, A 4.

FOLHA DE S.PAULO - Latifúndios e tecnologias afastam população. Folha de S.Paulo, Cotidiano, 21/01/2001, C 2.

FOLHA DE S.PAULO - Corrida à soja infla preço da terra agrícola. Folha de S.Paulo, Dinheiro, 20/05/2003, B 12.

FOLHA DE S.PAULO - Tecnologia cortou 10,8 milhões de empregos. Folha de S.Paulo, Dinheiro, 18/01/2004, B 1.

FOLHA DE S.PAULO - Impunidade mantém o trabalho escravo. Folha de S.Paulo, Brasil, 01/02/2004, A 5.

FOLHA DE S.PAULO - Sorriso, capital da soja, cresce $13 \%$ ao ano. Folha de S.Paulo, 14/03/2004, B 9.

FOLHA DE S.PAULO - Crédito agrícola cresce à margem do governo. Folha de S.Paulo, Dinheiro, 11/04/2004, B 5.

FOLHA DE S.PAULO - Agronegócio e pecuária de ponta usam trabalho escravo. Folha de S.Paulo, Brasil, 18/07/2004, A 4.

FOLHA DE S.PAULO - 'Exuberância agrícola' se aproxima do fim. Folha de S.Paulo, Dinheiro, 22/08/2004, B 4.

FOLHA DE S.PAULO - Mecanização engorda fileira de sem-terra. Folha de S.Paulo, Dinheiro, 12/09/2004, B 8. 
FOLHA DE S.PAULO - Desmatamento é 'efeito colateral' de expansão. Folha de S.Paulo, Dinheiro, 26/11/2004, B 5.

FOLHA DE S.PAULO - Piauí vira o novo eldorado para os gaúchos. Folha de S.Paulo, Dinheiro, 08/05/2005, B 8.

FOLHA DE S.PAULO - Soja em queda desvaloriza preço das terras. Folha de S.Paulo, Dinheiro, 26/07/2005, B 10.

FOLHA DE S.PAULO - Ação contesta negócio feito por Santos. Folha de S.Paulo, Dinheiro, 18/03/2006, B 4.

FOLHA DE S.PAULO - País segue vulnerável na nova ordem mundial. Folha de S.Paulo, Dinheiro, 12/03/2006, B 7.

FOLHA DE S.PAULO - Gripe aviária ameaça emergentes, diz FMI. Folha de S.Paulo, Dinheiro, 14/03/2006, B-12.

FOLHA DE S. PAULO - Soja avança sobre o mercado do biodiesel. Folha de S.Paulo, Dinheiro, 19/11/2006, B 1.

GAZETA MERCANTIL - Dossiê Piauí. Gazeta Mercantil, Relatório, 19/08/1998, p. 1-4.

GLOBO RURAL - Fronteira Aberta: soja atrai produtores e $R \$ 420$ milhões para o Piauí. Globo Rural, Negócio, ano 18, no.212, junho de 2003.

ISTO É - O cerrado vira lenha. ISTO É, n 1775, 08/10/2003. pp. 96-98.

MEIO NORTE - Soja será decisiva no aumento do PIB do PI para 15 bilhões.

Meio Norte, Especial sobre os cerrados piauienses, 12/06/2003, D/1.

MEIO NORTE - Agronegócio atrai investimentos de indianos e japoneses para o PI. Meio Norte, Política, 24/04/2005, p. 1.

MEIO NORTE - PF investiga máfia estrangeira na grilagem de terras no Piauí. Meio Norte, 19/06/2005, A/3.

MEIO NORTE - Município de Santa Filomena terá ação contra grileiros. Meio Norte, Municípios, 07/07/2005.

MEIO NORTE - Pl: vice-líder de mão-de-obra escrava. Meio Norte, Cidades, 10/07/2005, B/5.

MEIO NORTE - Descoberto trabalho escravo no Piauí. Meio Norte, 26/07/2004, p.1-2.

NOBRE, Carlos A.; ASSAD, Eduardo D. \& OYAMA, D. - Mudança ambiental no Brasil. SCIENTIFICAMERICAN (BRASIL), Edição Especial (Terra na Estufa), $n^{\circ} 12,2006$. pp.71-75. 
O ESTADO DE S. PAULO - Novíssima Fronteira. O Estado de São Paulo, Especial, 20/09/02. Disponível em: http://www.estadao.com.br.

O ESTADO DE S. PAULO - Piauí investigará suspeita de mortes por agrotóxicos. O Estado de S. Paulo, 27/10/2005.

PORTAL AZ - Bunge financiou eleição de políticos que agora a estão defendendo. Portal az, 28/08/2004. Disponível em: http://www.portalaz.com.br.

PORTAL AZ - Justiça manda realizar audiência sobre projetos da Graúna e Bunge. Portal az, 14/05/2004. Disponível em: http://www.portalaz.com.br. 